$$
\begin{gathered}
\text { UNIVERSIDADE DE SÃO PAULO } \\
\text { INSTITUTO DE RELAÇÕES INTERNACIONAIS }
\end{gathered}
$$

Daniel Duarte Flora Carvalho

\title{
Falência de Estados na África Subsaariana: uma questão de autoridade
}




\section{DANIEL DUARTE FLORA CARVALHO}

\section{Falência de Estados na África Subsaariana: uma questão de autoridade}

Tese apresentada ao Programa de Pós-Graduação em Relações Internacionais do Instituto de Relações Internacionais da Universidade de São Paulo, para a obtenção do título de Doutor em Ciências.

Orientador: Prof. Dr. Pedro Bohomoletz de Abreu Dallari

\section{Versão corrigida}

A versão original se encontra disponível na Biblioteca do Instituto de Relações Internacionais e na Biblioteca Digital de Teses e Dissertações da USP, documentos impresso e eletrônico. 
Autorizo a reprodução e divulgação total ou parcial deste trabalho, por qualquer meio convencional ou eletrônico, para fins de estudo e pesquisa, desde que citada a fonte.

\section{Catalogação na Publicação*}

Instituto de Relações Internacionais da Universidade de São Paulo

Carvalho, Daniel Duarte Flora

Falência de Estados na África Subsaariana : uma questão de autoridade / Daniel Duarte Flora Carvalho --

Orientador: Pedro Bohomoletz de Abreu Dallari. São Paulo: 2017. 259p.

Tese (Doutorado) - Instituto de Relações Internacionais. Universidade de São Paulo.

1. África. 2. Conflitos Internacionais. 3. Estado (Política). I. Dallari, Pedro Bohomoletz de Abreu. II. Título. 
Ao Vô João, que vai contar para todos lá no céu que tem mais um neto "dotô". 


\section{Agradecimentos}

Agradeço a Deus Pai, diante de quem meus joelhos sempre se dobram, por ter-me dado as condições para chegar tão longe. Deu-me paciência para perseverar e forças para superar todos os obstáculos que se me apresentaram.

À Virgem de Guadalupe - a Moreninha - que desde sempre me acompanha, ilumina meu caminho e intercede por mim. Enquanto estive na África, tive certeza que também lá vigiava-me e protegia-me. Que a música e as flores que ofereceu a seu confidente, Juan Diego, me mantenham firme no caminho de seu filho, o Cristo Jesus.

A meus pais, Pedro e Ana, e minha irmã, Andréa, que sempre me apoiaram nesta jornada. Distraíram-me quando precisei, socorreram-me quando minha coluna não me deixou mais trabalhar e, acima de tudo, são a minha família. São responsáveis pelo ambiente em que cresci e que me deu a vontade de desvendar essa coisa chamada "mundo".

À Moara, namorada, amiga e companheira, que me acalmou quando precisei, que aguentou meu mau-humor em alguns momentos do doutorado, que debateu comigo todas as ideias que tive e esbravejou contra meu "radicalismo". Debater com ela é sempre divertido e enriquecedor. Foi - e é - porto seguro que, com calma e ternura, faz-me refletir e arrumar as ideias. Também à sua família (Geraldo, Marcia, Tracy e Tobias) que, junto dela, aguentou minha bagunça quando tive que escrever a tese na casa deles.

Ao Instituto de Relações Internacionais da USP e a todos nele que, de alguma forma, contribuíram para o sucesso desta etapa. Assim, agradeço especialmente ao Prof. Dr. Pedro Bohomoletz de Abreu Dallari pela orientação. Seus conselhos ajudaram bastante o projeto de pesquisa que hoje é esta tese.

Laastens bedank ek Universiteit Stellenbosch. Hulle het my verwelkom en toegang tot al fasiliteite en hulle boekeversameling oor Afrika en internasionale verhoudings gegee. Ek is seker dat die universiteit se vriendelike navorsingsomgewing daadwerklik tot my tesis bygedra het. ' $n$ Spesiale woord van dank aan professor Pierre du Toit en meneer G. S. Swart wat vir my belangrike insigte in my navorsing gegee het. Ek bedank ook al my vriende wat ek by die universiteit gemaak het, spesifiek Alexandra, Arne, Lívia, Maik en Ricarda. My semester sou nie so vrugbaar gewees het as hulle nie daar was nie. 


\section{Resumo}

Este trabalho tem como objetivo avaliar o papel da autoridade estatal e do desenvolvimento na estabilidade dos Estados da África Subsaariana e a influência que têm nos processos de falência estatal e de eclosão de guerras intraestatais. Desde o fim da Guerra Fria, a corrente de pensamento que fundia segurança e desenvolvimento tornouse predominante para analisar as causas e fornecer sugestões de políticas para impedir que os Estados sucumbissem a dinâmicas de violência, fomentadas por necessidade, ganância e agravo - todos gerados e intensificados em situações de subdesenvolvimento. Palco de boa parte dos países menos desenvolvidos (PMDs) do mundo e da grande maioria dos conflitos intraestatais que ocorreram nos últimos trinta anos, a África Subsaariana foi retratada como locus immutabilis, cujos problemas tinham poucas ou nenhuma solução possível. Desta forma, o subdesenvolvimento endêmico da região foi usado como guarda-chuva conceitual uma vez que intensificaria as consequências nocivas de certos tipos de regimes políticos, da distribuição desigual das riquezas e oportunidades econômicas e da incompatibilidade étnica que existiria em seus países. Seguindo esta linha de pensamento, bastaria resolver a situação do subdesenvolvimento nos Estados da África Subsaariana que seus processos de falência seriam revertidos e as guerras civis não mais aconteceriam. No entanto, é possível questionar esta relação entre segurança e desenvolvimento dado que países que têm o mesmo nível de subdesenvolvimento diferiram em seus destinos, tendo alguns sucumbido às dinâmicas violentas e outros não. Este trabalho pretende, portanto, identificar as causas das guerras civis e da falência de Estados na região. Este trabalho argumenta que é a baixa autoridade estatal (e não o subdesenvolvimento) a condição determinante para o advento de guerras civis e da falência de Estado na África Subsaariana. Para chegar a tal resultado, analisou-se os dados de 44 Estados da região fornecidos pelo Worldwide Governance Indicators do Banco Mundial e os mesmos dados utilizados pela ONU para classificar os PMDs. Também se utilizou análise qualitativa sobre a história dos países onde a paz imperou desde a independência para avaliar as fundações da autoridade estatal.

Palavras-chave: África Subsaariana, autoridade estatal, subdesenvolvimento, falência de Estados; guerra intraestatal. 


\section{Abstract}

This thesis looks forward to assessing the role of state authority and development in the stability of Sub-Saharan African states and their influence on state failure processes and on the outbreak of intra-state wars. Since the end of the Cold War, the current of thought that merged security and development has become prevalent in analysing the causes and in providing policy suggestions to prevent states from succumbing to dynamics of violence fuelled by need, greed, and grievance - which are generated and intensified in situations of underdevelopment. As the stage for most of the world's least developed countries and the largest number of intrastate conflicts that have taken place over the last thirty years, Sub-Saharan Africa has been portrayed as locus immutabilis, whose problems had few or none feasible solutions. In this regard, the region's endemic underdevelopment was used as a conceptual umbrella since it would intensify the harmful consequences of certain types of political regimes, of the unequal distribution of wealth and economic opportunities, and the ethnic incompatibility that would exist in their countries. Following this line of thought, resolving the situation of underdevelopment in Sub-Saharan African states would suffice to reverse processes of state failure and civil wars would no longer happen. However, it is possible to question this relationship between security and development since countries that have the same level of underdevelopment had different outcomes, having some of them capitulated to violent dynamics and others not. This thesis therefore aims to identify the causes of civil wars and state failure in the region. It argues that it is the low level of state authority (and not underdevelopment) that is the determining factor for the advent of civil wars and state failure in Sub-Saharan Africa. In order to achieve this result data from 44 countries in the region provided by the World Bank's Worldwide Governance Indicators and the same data used by the UN to classify the LDCs were analysed. Qualitative analysis was also conducted about the history of countries where peace has prevailed since independence to assess the foundations of state authority.

Keywords: Sub-Saharan Africa, state authority, underdevelopment, state failure; intrastate war 


\section{Ilustrações}

FIGURA 1 - ORDEM DOS ESTADOS EM TERMOS DE AUTORIDADE MÉDIA ENTRE 1996 E 2011

FIGURA 2 - CLASSIFICAÇÃO DE PAÍS COM OU SEM CONFLITO COM RELAÇÃO A CONFLITOS INTRAESTATAIS.

FIGURA 3 - CLASSIFICAÇÃO DE PAÍS COM OU SEM CONFLITO COM RELAÇÃO A CONFLITOS NÃO-ESTATAIS.

FIGURA 4 - PMDS DA ÁFRICA QUE NÃO TIVERAM GUERRAS CIVIS, CONFLITOS MENORES OU CONFLITOS NÃO-ESTATAIS

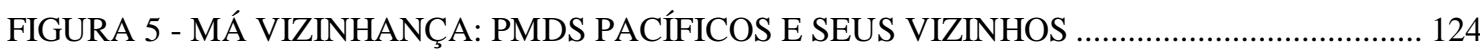

FIGURA 6 - NÃO-PMDS DA ÁFRICA QUE NÃO TIVERAM GUERRAS CIVIS, CONFLITOS

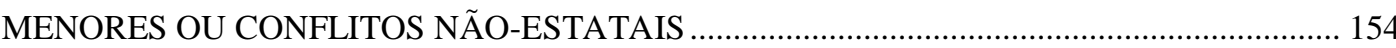

FIGURA 7 - MÁ VIZINHANÇA: NÃO-PMDS PACÍFICOS E SEUS VIZINHOS ................................. 156

GRÁFICO 1 - DISTRIBUIÇÃ̃O DOS 178 ESTADOS AVALIADOS PELA FOREIGN POLICY EM 2014.

GRÁFICO 2 - EVOLUÇÃO DO DESENVOLVIMENTO E DA AUTORIDADE EM RUANDA ENTRE 1990 E 2011.

GRÁFICO 3 - EVOLUÇÃO DO DESENVOLVIMENTO E DA AUTORIDADE NA LIBÉRIA ENTRE 1990 E 2011. FICO 4 - EVOLUÇÃO DO DESENVOLVIMENTO E DA AUTORIDADE NA COSTA DO

GRÁFICO 4 - EVOLUÇÃO DO DESEN
MARFIM ENTRE 1990 E 2011.

GRÁFICO 5 - EVOLUÇÃO DA AUTORIDADE ESTATAL ENTRE 1996 E 2011 (CASOS SELECIONADOS)

GRÁFICO 6 - EVOLUÇÃO NO INDICADOR "AUSÊNCIA DE VIOLÊNCIA POLÍTICA/TERRORISMO" ENTRE 1996-2011 (CASOS SELECIONADOS)

GRÁFICO 7 - EVOLUÇÃO NA EFICÁCIA DA GOVERNANÇA ENTRE 1996 E 2011 (CASOS SELECIONADOS)

GRÁFICO 8 - EVOLUÇÃO DA NOMOCRACIA 1996-2011

TABELA 1- LISTA DE PAÍSES CONFORME A OCORRÊNCIA DE GUERRA CIVIL OU CONFLITOS

NÃO-ESTATAIS EM SUA HISTÓRIA INDEPENDENTE

TABELA 2 - QUESTÃO ÉTNICA NOS PMDS QUE NÃO PASSARAM POR GUERRAS CIVIS E RUANDA E LIBÉRIA

TABELA 3 - OBEDIÊNCIA AO GOVERNO, INDEPENDENTEMENTE DE PARA QUEM SE VOTOU

TABELA 4 - GRAU DE SEMELHANÇA COM ESTADO DE MORRISON, MITCHELL E PADEN (1989)

TABELA 5 - PROPRIEDADE DA TERRA NOS PMDS SEM GUERRA CIVIL

TABELA 6 - RESPONSABILIDADE PRIMÁRIA DE ELEMENTOS DA GOVERNANÇA DO ESTADO NOS PMDS PACÍFICOS

TABELA 7 - QUESTÃO ÉTNICA NOS NÃO-PMDS QUE NÃO PASSARAM POR GUERRAS CIVIL E RUANDA E LIBÉRIA

TABELA 8 - OBEDIÊNCIA AO GOVERNO, INDEPENDENTEMENTE DE PARA QUEM SE VOTOU

TABELA 9 - GRAU DE SEMELHANÇA COM ESTADO DE MORRISON, MITCHELL E PADEN $(1989)^{\mathrm{E}}$

TABELA 10 - PROPRIEDADE DA TERRA NOS NÃO-PMDS SEM GUERRA CIVIL 186

TABELA 11 - RESPONSABILIDADE PRIMÁRIA DE ELEMENTOS DA GOVERNANÇA DO ESTADO NOS PMDS PACÍFICOS

TABELA 12 - PAÍSES COM CORRELAÇÃO ALTA E POSITIVA ENTRE AUTORIDADE E DESENVOLVIMENTO ENTRE 1996 E 2011 


\section{Siglas e Abreviações}

ACDREC - Alto Comissariado para a Desmobilização e Reintegração dos ExCombatentes

ARB - Associação dos Reis do Benim

BAD - Banco Africano de Desenvolvimento

$\mathrm{BM}$ - Banco Mundial

CAACH - Comitê de Acompanhamento do Acordo de Cessação de Hostilidades

CAFRA - Conselho de Administração das Famílias Reais de Abomei

CBAS - Companhia Britânica da África do Sul

CCM - Chama cha Mapinduzi (Partido da Revolução, em suaíle)

CDHNU - Conselho de Direitos Humanos das Nações Unidas

CHADEMA - Chama cha Demokrasia na Maendeleo (Partido da Democracia e do Progresso em suaíle)

CNA - Congresso Nacional Africano

CONADER - Comissão Nacional de Desarmamento, Desmobilização e Reinserção dos Ex-Combatentes

CNDDRR - Comissão Nacional de Desarmamento, Desmobilização, Reabilitação e Reintegração

CPL - Conselho de Paz Liberiano

CRDR - Comissão Ruandesa de Desmobilização e Reintegração

DDR - Desarmamento, Desmobilização e Reintegração

ECOMOG - Grupo de Monitoramento do Cessar-Fogo dos Estados da Comunidade dos Estados da África Ocidental

ELC - Exército de Libertação de Caprivi 
EPRu - Exército Patriota Ruandês

FAA - Forças Armadas Angolanas

FDN - Forças de Defesa da Namíbia

FDR - Forças de Autodefesa da Resistência

FALA - Forças Armadas de Libertação de Angola

FAPLA - Forças Armadas Populares de Libertação de Angola

FMI - Fundo Monetário Internacional

FNLA - Frente Nacional para a Libertação de Angola

FPLT - Frente Popular de Libertação do Tigré

FPM - Frente Popular Marfinense

FPNL - Frente Patriótica Nacional da Libéria

FPR - Frente Patriótica Ruandesa

GCIL - Grupo de Contato Internacional sobre a Libéria

GdL - Governo da Libéria

GIAMDA - Gabinete Interministerial de Apoio aos Desmobilizados das Forças Armadas

GNTL - Governo Nacional de Transição da Libéria

GURN - Governo de União e Reconciliação Nacional

IRSEM - Instituto de Reintegração Sócio-Profissional dos ex-Militares

LURD - Liberianos Unidos pela Reconciliação e Democracia

MCDDI - Movimento Congolês para a Democracia e Desenvolvimento Integral

MDC - Movimento para Mudança Democrática

MDU - Movimento Democrático Unido

MLSTP - Movimento de Libertação de São Tomé e Príncipe 
MNLA - Movimento Nacional de Libertação do Azauade

MODEL - Movimento para Democracia na Libéria

MPLA - Movimento Popular para a Libertação de Angola

MRNDD - Movimento Republicano Nacional para Democracia e Desenvolvimento

MULLD - Movimento Unido de Libertação da Libéria para Democracia

ODM - Objetivos de Desenvolvimento do Milênio

OIM - Organização Internacional para Migrações

ONU - Organização das Nações Unidas

PCT - Partido Congolês do Trabalho

PDG - Partido Democrático Gabonês

PDRA - Programa de Desmobilização e Reintegração de Angola

PDRDM - Programa de Desmobilização e Reintegração de Doadores Múltiplos

PGDR - Programa Geral de Desmobilização e Reintegração

PLI - Partido da Liberdade Inkatha

PMD - Países Menos Desenvolvidos

PNA - Polícia Nacional Angolana

PNDDR - Programa Nacional de Desarmamento, Desmobilização e Reintegração

PNUD - Programa das Nações Unidas para o Desenvolvimento

PRERC - Programa de Reintegração de Emergência da República do Congo

PUDN - Partido Unido para o Desenvolvimento Nacional

PUID - Partido Unido da Independência Nacional

SADC - Comunidade para o Desenvolvimento da África Austral

SWAPO - Organização do Povo do Sudoeste Africano 
UCI - União das Cortes Islâmicas

UIC - Unidade de Implementação Conjunta

UE - União Europeia

UNAMIR - Missão de Assistência das Nações Unidas para Ruanda

UNAVEM I - Primeira Missão de Verificação das Nações Unidas em Angola

UNAVEM II - Segunda Missão de Verificação das Nações Unidas em Angola

UNCTAD - Conferência das Nações Unidas sobre Comércio e Desenvolvimento

UNICEF - Fundo das Nações Unidas para a Infância

UNITA - União Nacional para a Independência Total de Angola

UNM - União Nacional dos Mineiradores

UNMIL - Missão das Nações Unidas na Libéria

UNOMIL - Missão de Observação das Nações Unidas na Libéria

UNPOL - Polícia das Nações Unidas

UPADS - União Pan-africana para a Democracia Social

UPS - União Progressista Senegalesa

USAID - Agência dos Estados Unidos para o Desenvolvimento Internacional

UTUAS - União dos Trabalhadores Unidos da África do Sul

ZANU-PF - União Nacional Africana do Zimbábue - Frente Popular 


\section{Sumário}

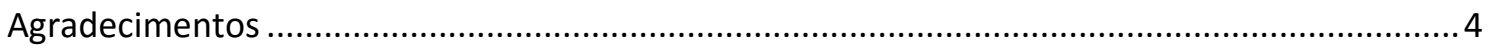

Resumo

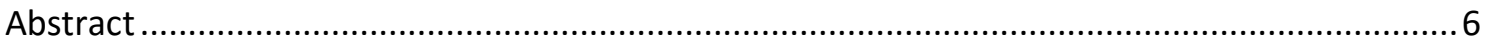

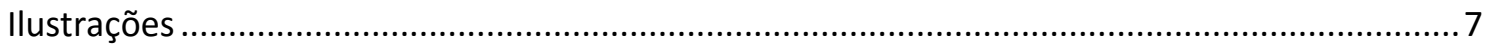

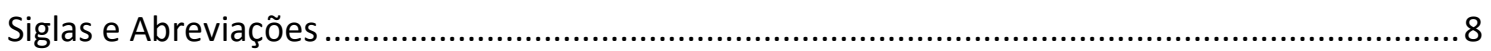

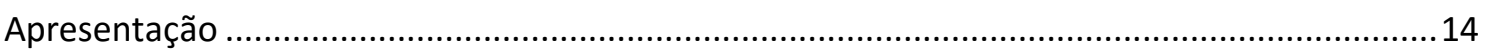

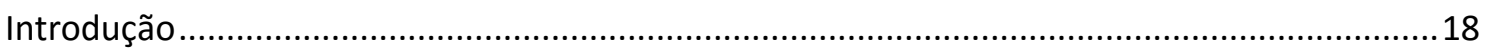

PARTE 1 - A relação entre autoridade, desenvolvimento e conflitos na África Subsaariana .....44

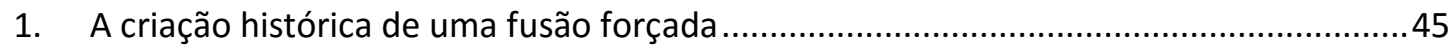

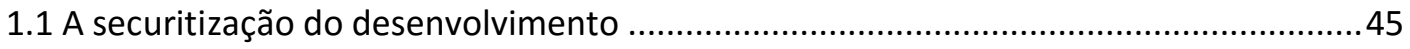

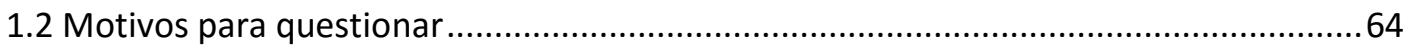

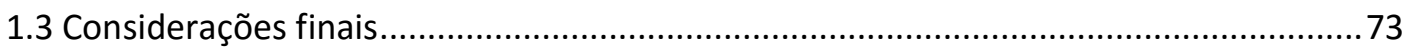

2. Construção de autoridade como construção de Estado.................................................74

2.1 A autoridade estatal como viabilizadora do Estado .......................................................74

2.2 A historicidade e a atualidade do Estado na África Subsaariana ...................................93

2.3 Exercício da autoridade estatal: funções e atores .....................................................104

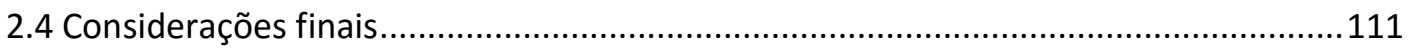

Parte II - Os caminhos para a paz e para o conflito …….......................................................113

3. Contra as probabilidades: a paz nos países menos desenvolvidos ...............................120

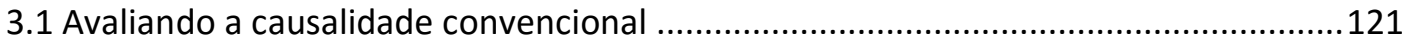

3.2 Continuidade das civilizações, geografia política e legitimidade estatal......................126

3.3 Costume, resiliência e capilaridade da autoridade estatal.........................................136

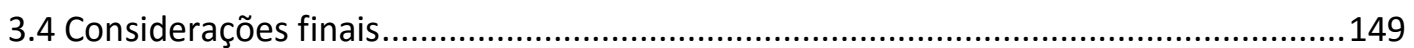

4. Os não-PMDs e construção da autoridade estatal .......................................................152

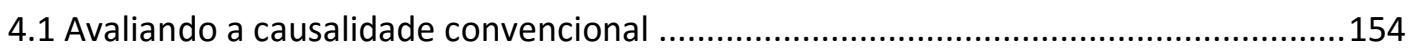

4.2 Continuidade das civilizações, geografia política e legitimidade estatal......................167

4.3 Costume, resiliência e capilaridade da autoridade estatal.........................................183

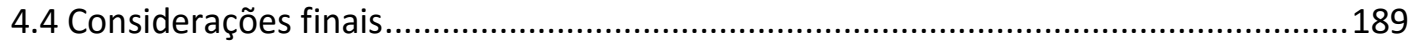

5. Reconstrução da autoridade como solução e prevenção de conflitos..........................191

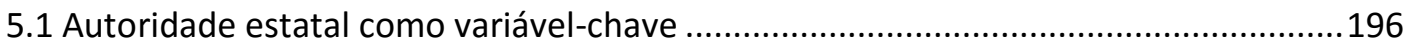

5.2 Reconstrução da autoridade estatal como solução de conflitos.................................204

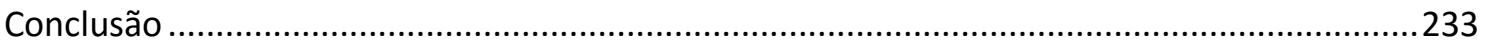

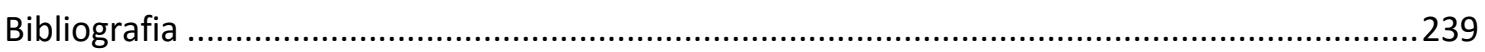


Apêndice I - Indicadores, fontes e definições.

Apêndice II - Dados sobre Autoridade .................................................................260

Apêndice III - Dados sobre Desenvolvimento ............................................................263

Apêndice IV - Diversidade Étnica na África Subsaariana ..................................................267

Apêndice V - Pesquisa de opinião: Obediência ao governo...............................................269

Apêndice VI - Responsabilidade primária de elementos da governança .............................272

Anexo I - Grau de semelhança com o Estado.......................................................274

Anexo II - Modalidades de posse da terra na África Subsaariana ....................................276

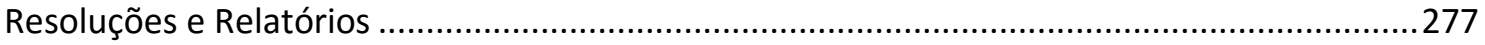

Assembleia Geral das Nações Unidas ......................................................................277

Conselho de Segurança das Nações Unidas.................................................................277

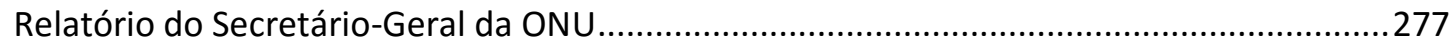

Relatório do Conselho de Direitos Humanos da ONU ...................................................277 


\section{Apresentação}

Quando comecei minha graduação em Relações Internacionais na PUC-SP, não imaginava que um dia fosse me interessar por estudar a África Subsaariana. Ainda tinha em minha mente muitos estereótipos criados na mídia e reforçados pela história e geografia eurocêntricas ensinadas no Ensino Médio e, assim, não via como tal continente poderia acrescentar algo em minha formação. Estava tudo muito claro: as coisas não funcionam por causa da farra que os colonizadores fizeram por lá, ignorando tudo e todos. Juntaram etnias que não se entendiam, que se odiavam, e separaram aquelas que podiam ou até mesmo queriam viver juntas. Levaram para lá o Estado, algo inexistente no continente, e assim a incompatibilidade entre uma instituição moderna e uma população pré-moderna não poderia ser resolvida. Na minha mente, ainda pensava que a África era um continente de problemas, de miséria e guerras por todo o lado e que jamais sairia deste patamar.

Tudo isso começou a mudar quando fui participar do VII Americas Model United Nations em 2004 e tive que representar a Etiópia. Ao começar a me preparar para aquela simulação e estudar um pouco da história do país, surpreendi-me com o fato de este país não ter sido colonizado, ter seu próprio patriarcado cristão e, acima de tudo, ter tido impacto na minha família muito antes de eu nascer. Foi quando descobri que meu tataravô, italiano, Biase Flora foi soldado do exército italiano e esteve na Etiópia em 1896. Pelas histórias que minha família colecionou dele, é bem provável que ele tenha estado na icônica Batalha de Adwa, quando os italianos foram escorraçados pelas tropas de Menelik II. Isso tudo me despertou grande interesse por aquele país, mas ainda não sobre o continente. Algo que só viria a acontecer no último ano da graduação quando li uma notícia de que guerrilheiros somalis haviam derrubado em Mogadíscio um avião que transportava peacekeepers africanos. Surpreso com a duração da guerra civil e ainda lembrando-me de algumas memórias de quando era pequeno de notícias sobre fome na Somália, fiquei intrigado e comecei a pesquisar sobre aquele Estado falido e seus vizinhos, principalmente sua relação com a Etiópia. Foi sobre isso que fiz meu Trabalho de Conclusão de Curso e meu mestrado.

Nenhuma daquelas tradicionais explicações usadas para esclarecer os acontecimentos na África me fazia sentido quando aplicadas para a região que eu estudava. Se o problema eram as etnias, por que a praticamente homogênea Somália implodiu? Se o problema são as fronteiras, por que elas não mudam? Se o problema é a 
falta de democracia, por que a quantidade de guerras interestatais no continente é tão baixa? Aliás, por que são feitas tão poucas menções à África na graduação em Relações Internacionais? Por que se costuma tratar a África como uma categoria única e homogênea e não como uma região heterogênea cujos Estados apresentam diferenças significativas no tocante à paz e à guerra, ao desenvolvimento, à democracia etc? Estas perguntas mantiveram-me intrigado por um bom tempo desde que comecei a me aprofundar no estudo sobre aquele continente e me incentivaram cada vez mais a buscar respostas para elas e explicações para os acontecimentos políticos na África.

De todos esses assuntos, três questões sempre me chamaram bastante a atenção. Primeiro, os processos de consolidação e falência das instituições estatais na África Subsaariana. As instituições deixadas pelos colonizadores foram, em boa medida, mantidas e, muitas vezes, tornaram-se alvo de disputa política pela via armada. Além disso, a falta de legitimidade dessas instituições perante suas populações teria um potencial para que as leis e decisões dos governos não fossem obedecidas. Segundo, a questão da segurança (da paz e da guerra) de um modo geral também me atraia. A África Subsaariana é retratada como lugar onde guerras endêmicas tiveram e têm lugar recorrentemente. Estórias de drama e sofrimento causados por esses conflitos costumam ocupar o pouco espaço dado ao continente na mídia (principalmente brasileira) e constroem uma imagem que não condiz com a realidade de pelo menos metade dos países do continente. $\mathrm{O}$ mesmo vale para as questões de desenvolvimento (o terceiro assunto que sempre me atraiu). As antigas imagens da fome durante o conflito do Biafra (197650) e da Etiópia e do Sudão nos anos 1980 e 1990 foram retratadas não como crises em certos países da África, mas sim como crises na África. Esse tom generalizante fez com que uma vez um aluno me perguntasse "como é lá na África”, se é verdade que as pessoas estão realmente morrendo de fome. Tal pergunta foi-me feita mais de vinte anos depois dessas crises.

A intersecção destas três grandes questões deu origem a esta tese de doutorado. Apesar de a tese que vincula segurança e desenvolvimento e que afirma que onde não há desenvolvimento, haverá conflitos e que onde há conflitos, não haverá desenvolvimento ser quase consensual na academia hoje, ela induz a uma situação inexistente: pelo menos 34 países da África Subsaariana deveriam estar em conflito constante uma vez que estão entre os menos desenvolvidos do mundo. Isto, contudo, não é o caso já que quase um terço deles nunca passou por conflitos intraestatais ou não-estatais. Estes países pacíficos 
são, no geral, pluriétnicos, foram colonizados, tiveram instituições impostas, etc. Atendem a todas as características que costumam ser apontadas como o problema dos Estados da África Subsaariana. Além disso, outros países que não estão entre os menos desenvolvidos do mundo ainda são subdesenvolvidos e mesmo assim são pacíficos. Ora! Estes países fizeram-me questionar veementemente a relação entre segurança e desenvolvimento.

Outro ponto que sempre me chamou muito a atenção desde quando resolvi focar meus estudos na África Subsaariana foi sua impressionante marginalização nas Relações Internacionais. Além das críticas a esta ciência de que ela não seria tão internacional $\operatorname{assim}^{1}$ ou de que seria apenas uma ciência social americana ${ }^{2}$, que já denunciavam uma preferência geoepistemológica, uma série de estudos foram feitos no começo dos anos 2000 demonstrando, especificamente, como a África (principalmente sua porção subsaariana) era a região mais marginalizada em dita ciência. É raro encontrar em um livro didático de Relações Internacionais uma menção à região. Do mesmo jeito, livros clássicos de teorias de Relações Internacionais, tal como o livro Teoria da Política Internacional de Kenneth Waltz, não incluem a região em suas reflexões e na construção de suas causalidades. Essa impressão foi confirmada pelo resultado da pesquisa TRIP around the world, publicada em 2012 (logo antes de eu entrar no doutorado), apontou uma imensa discrepância no tempo dedicado à África e a outras regiões por professores da área tanto na graduação quanto no mestrado. ${ }^{3}$ Além disso, os periódicos que tal pesquisa apontou como os mais influentes de Relações Internacionais praticamente não publicaram nada sobre o continente entre 2001 e 2012: dos 2153 artigos e ensaios publicados no período, apenas 2,56\% eram sobre a África Subsaariana. ${ }^{4}$ Especificamente no caso do Instituo de Relações Internacionais da Universidade de São Paulo, a baixa

\footnotetext{
${ }^{1}$ Wæver, O. (1998). The Sociology of a Not So International Discipline: American and European Developments in International Relations. International Organization, 52(4), 687-727.

${ }^{2}$ Hoffmann, S. (1977). An American Social Science: International Relations. Daedalus, 106(3), 41-60.

${ }^{3}$ Maliniak, Daniel, Susan Peterson, e Michael J. Tierney. TRIP Around the World: teaching, research and policy views of International Relations Raculty in 20 countries. Survey, Williamsburg: The Institute for the Theory and Practice of International Relations, 2012.

${ }^{4}$ International Organization, International Studies Quarterly, International Security, Foreign Affairs e American Political Science Review. Esta contagem foi feita por mim em uma pesquisa para a disciplina de Teorias Avançadas de Relações Internacionais, em 2013.
} 
preocupação com os acontecimentos da África também se reflete: esta foi a primeira tese de doutorado do programa sobre a África. Espero que muitas outras venham a ser feitas. ${ }^{5}$

Durante os quatro anos do doutorado, visitei oito países da África (África do Sul, onde fiquei por seis meses pesquisando na Universiteit Stellenbosch; Botsuana; Namíbia; Zimbábue; Etiópia; Maláui; Tanzânia; e Zâmbia). Os últimos quatro estão na lista de países menos desenvolvidos do mundo e Botsuana deixou essa categoria em 1994. Além disso, deles apenas a África do Sul e a Etiópia passaram por guerras civis em sua história e hoje são países estáveis e que tem conseguido apresentar marcas bastante importantes no tocante ao desenvolvimento (a primeira atualmente faz parte dos BRICS e a segunda está entre as economias que mais cresceram nos últimos 10 anos e teve melhorias notáveis na área da saúde entre os anos de 2000 e 2015). O período em que estive neles colaborou não apenas para a coleta de dados e informações para esta tese, mas principalmente para ter um senso (ainda que pequeno) de como os africanos levam a vida e lidam com a fragilidade e resiliência do Estado e o subdesenvolvimento. Histórias como as de quando eu fui abandonado na fronteira entre Botsuana e Zimbábue, as dificuldades que enfrentei com transporte para ir de Lusaka, Zâmbia, a Senga, Maláui, e as duas vezes em que soldados etíopes nada amigáveis apontaram suas AK-47 para mim certamente contribuíram para a construção de um imaginário mais próximo das realidades africanas: as coisas funcionam! De algum jeito, mas funcionam!

É com base nessa ideia que gostaria que o leitor lesse as páginas que seguem. Elas são baseadas, portanto, não apenas nos livros, artigos que li e sobre os quais refleti ou então nos dados que coletei ao longo desses quatro anos de doutorado, mas também apresentam o resultado de minhas reflexões particulares sobre quando estive nesses locais. Espero ter dado minha contribuição para o estudo da África Subsaariana nas Relações Internacionais aqui no Brasil e, principalmente, espero receber muito mais contribuições com outras dissertações e teses sobre o assunto.

\footnotetext{
${ }^{5}$ Há teses de doutorado e dissertações de mestrado que versam sobre as relações do Brasil com a África ou com algum país africano específico. Integralmente focado na África ou em algum(s) país(es) dela, são a dissertação de mestrado de Celso Medina Santos (Integração regional e desenvolvimento: o caso da Comunidade dos Estados da África Ocidental (CEDEAO), de 2014) e de José Antônio Geraldes Graziani Viera Lima (A ascensão da Irmandade Muçulmana ao poder no Egito e seus impactos na política externa egípcia, de 2015).
} 


\section{Introdução}

Desde os estágios finais da Guerra Fria, a imagem da África Subsaariana foi moldada pelos conflitos e pela pobreza. Muitos acadêmicos, veículos midiáticos e policymakers reproduzem, ainda hoje, uma linha de pensamento que reflete esta imagem e que poderia facilmente ser chamada de "afropessimismo" ou "afrofobia". Direta ou indiretamente, muitos afirmam que os problemas da região ou são insolúveis ou tem apenas poucas soluções cabíveis. De fato, este raciocínio foi alardeado durante os últimos 30 anos e, tirando-se o exagero que traz consigo, tem algum fundo de verdade. Muitos conflitos eclodiram ou passaram por uma escalada maior da violência durante a década de 1990 enquanto muitas imagens de fome ganharam as manchetes dos principais e mais influentes jornais ocidentais.

As guerras civis aparentemente intermináveis e generalizadas, a fome e a extrema pobreza no continente, entretanto, escondem casos de sucesso e de estabilidade que foram ou ofuscados ou ignorados pela mídia ocidental e por muitos acadêmicos durante os anos 1990. Apesar de ser verdade que países como Angola, Libéria, Ruanda, Serra Leoa, Somália e Sudão foram palcos de novos conflitos ou da escalada de violência entre rivalidades antigas, é igualmente verdade que países como Benim, Burquina Faso, Eritreia, Gâmbia, Tanzânia e Zâmbia nunca passaram por guerras civis desde a conclusão de seus processos de independência. ${ }^{6}$ Ainda que estes dois grupos de países apresentem diferenças retumbantes entre eles e que os levaram para diferentes caminhos rumo à estabilidade ou ao conflito, eles também têm uma característica em comum no que diz respeito às suas condições sociais e econômicas: todos os seus países estavam na lista

\footnotetext{
${ }^{6}$ Isto não quer dizer que estes países tenham sido livres de violência política durante sua história independente. Dos países mencionados, alguns bancos de dados como o Uppsala Conflict Data Program (2016) contabilizam Burquina Faso, Eritreia, Gâmbia por terem tido conflitos politicamente motivados em que ao menos uma das partes era o governo do país e que resultou em pelo menos 25 mortes relacionadas a batalhas em um ano calendário. Estes países são mencionados aqui, contudo, pois tais episódios não escalaram suficientemente para que fossem explicados tanto pela imprensa quanto por acadêmicos como uma guerra civil. Uma leitura mais aprofundada e rígida sobre países que não tiveram mortes suficientes para serem contados pelo UPCD será trabalhada no sétimo capítulo.
} 
Organização das Nações Unidas (ONU) dos países menos desenvolvidos do mundo (PMDs) ${ }^{7}$ em 2014 e lá estavam pelo menos desde $1994^{8}$.

Naquela época, três tentativas de explicar a notória situação do continente foram feitas. Em primeiro lugar, argumentou-se que o fim da Guerra Fria foi responsável por um descongelamento étnico que levou o continente a um processo de "balcanização" que fez com que desaparecesse cada vestígio de ordem e surgissem, assim, as guerras civis, os golpes de Estado, os genocídios e as violações em massa dos direitos humanos. De acordo com este pensamento, a disputa ideológica durante a Guerra Fria foi capaz de amenizar os antigos ódios entre as etnias, mas não de resolver os incentivos para a guerra entre elas. Nos países em que tal disputa não foi tão evidente ou não existiu, o problema foi dito ser uma consequência da existência de culturas incompatíveis dentro de um único Estado.

Em outras palavras, os conflitos na África Subsaariana que eclodiram na década de 1990 ou mesmo antes eram relacionados às questões de identidade e de etnia. Assim, o conflito entre tutsis e hutus tanto no Burundi quanto em Ruanda (que provocou um genocídio no segundo) e a guerra que estourou após a queda de Siad Barre na Somália foram étnicos da mesma forma que os agentes da guerra civil angolana tiveram suas bases em populações etnicamente definidas (Malaquias, 2001; Visentini, 2012). Tal argumento pode ser resumido da seguinte forma: "brancos e negros lutam entre si sobre quem possui o quê, negros lutam com negros sobre quem é quem" (Mazrui, 2008, p. 38) 9 .

A segunda tentativa para explicar os conflitos na África Subsaariana denunciou a natureza dos Estados africanos e a disputa pela autoridade e pela sobrevivência e segurança de seus regimes, dando eco ao argumento de Clapham (1996) de que o ambiente de apoio que visava a defender as soberanias dos Estados foi apropriado pelos governantes africanos com o objetivo de fortalecer domesticamente sua posição e poder. Com o intuito de garantir a soberania aos Estados e a permanência das elites governantes

\footnotetext{
${ }^{7}$ De acordo com a UNCTAD, a classificação dos PMDs obedece exclusivamente aos seguintes critérios sociais e econômicos: (i) renda per capita, cuja média dos últimos três anos deve ser inferior a US $\$ 992,00$ para que o país seja adicionado à lista e superior a US $\$ 1190,00$ para que possa ser retirado dela; (ii) recursos humanos, medido com base em indicadores tais como subnutrição, taxa de mortalidade infantil, taxa de matrículas no ensino secundário e alfabetização adulta; e (iii) vulnerabilidade econômica, com base na instabilidade da produção agrícola e das exportações de bens e serviços entre outros (UNCTAD, 2013).

${ }^{8}$ Angola e Eritreia foram os últimos a serem inseridos em tal categoria. Seis dos doze países mencionados estão na lista desde 1971, quando ela foi criada.

${ }^{9}$ Ênfase no original.
} 
no poder, os governos africanos veem o sistema contemporâneo de estatalidade como algo de grande proveito uma vez que tem como marco a Declaração sobre a Concessão de Independência a Países e Povos Coloniais (1960), que estabelece que a "inadequação da preparação política, econômica, social ou educacional nunca deve servir de pretexto para adiar a independência” dos Estados (AGNU, 1960) ${ }^{10}$.

Tal declaração não apenas converteu o reconhecimento internacional como o único requisito para a estatalidade como também permitiu o surgimento e a existência dos chamados "quase-estados", que não têm soberania empírica, mas são reconhecidos internacionalmente e desta forma mantêm-se independentes. Especificamente para o caso africano, ela provou ser mais um instrumento para a proteção de Estados fracos. Sentindose imunes a ameaças externas, as elites governantes na África Subsaariana tiveram que lidar com uma relativa falta de recursos e uma absoluta falta de legitimidade de seu governo e do próprio Estado.

Neste sentido, argumentou-se que os Estados na África não tinham se emancipado da sociedade e seu sistema político fora estabelecido garantindo a continuidade das instituições coloniais e fora apropriado para propósitos além do bem-estar e crescimento econômico. Portanto, eles tiveram de escolher entre a promoção deste e a sua manutenção no poder e, geralmente, preferiram o segundo ao primeiro e talvez esta seja a razão pela qual a ajuda financeira vinda do exterior raramente se transformou em desenvolvimento (Chabal \& Daloz, 2001; Englebert, 2000a; 2000b; Acemoglu \& Robinson, 2010; Why Nations Fail: the origins of power, prosperity, and poverty, 2012). Geralmente, recursos militares e financeiros fornecidos pelas grandes potências foram ferramentas úteis para suprimir revoltas e insurgências assim como para garantir apoio político. Por isso, os ajustes estruturais prescritos pelo Consenso de Washington desafiaram o estado neopatrimonial na África e a autoridade dos governantes, que tiveram que recorrer à força para conseguir aquilo que não conseguiam por persuasão (Clapham, 1998b).

A terceira explicação criada para dar conta desses eventos na África e em outros lugares foi aquela que fundia segurança e desenvolvimento e que deu origem à discussão de Estados falidos. Desde o começo dos anos 1990 e desde o reconhecimento de que as ameaças à paz e à segurança internacional poderiam vir de dentro dos Estados, o subdesenvolvimento tornou-se uma característica chave nas causas dos conflitos e foi

\footnotetext{
${ }^{10} \mathrm{~A} / \mathrm{RES} / 1514$ (XV) de 14 de dezembro de 1960.
} 
incorporado assim ao discurso dos Estados falidos. Após o lançamento do programa Linking Rehabilitation to Development em 1992 e do Relatório de Desenvolvimento Humano de 1994, ambos do Programa das Nações Unidas para o Desenvolvimento (PNUD), a perspectiva que começou preocupada com as situações na BósniaHerzegovina e na Somália representou uma mudança de uma lógica puramente focada na segurança territorial para uma com muito mais ênfase no desenvolvimento humano sustentável. No geral, conflitos e subdesenvolvimento podem ser encontrados nos chamados Estados falidos, o que endossa a tese que liga a segurança e o desenvolvimento e fortalece a suposta relação causal entre eles. De acordo com esta linha de pensamento, “o desenvolvimento é, em última análise, impossível sem estabilidade e, ao mesmo tempo, a segurança não é sustentável sem desenvolvimento" (Duffield, 2001, p. 16).

De fato, a década de 1990 foi uma das mais violentas na história da África Subsaariana e apesar de haver fortes conexões teóricas e conceituais entre estes três argumentos, o último parece ter guiado acadêmicos e policymakers mais do que os outros. Entretanto, é interessante notar que os indicadores que medem o desenvolvimento na África Subsaariana melhoraram suas médias desde os anos 1990 e que apenas três países (Chade, Serra Leoa e Zimbábue) estavam piores em 2011 do que em 1990. ${ }^{11}$ Somandose a isto o fato de que um número considerável de Estados naquela região pertence à categoria dos PMDs, parece haver razões suficientes para ao menos questionar a suposta relação entre segurança e desenvolvimento.

Se o subdesenvolvimento explica os conflitos na África Subsaariana e em outros lugares, deve-se esperar uma relação direta e forte entre eles. Em outras palavras, pelo menos um dos dois cenários que seguem deve existir. Primeiro, espera-se a coexistência entre eles na maioria dos países do mundo - ou ao menos nos PMDs - acompanhados de um ciclo vicioso no qual os conflitos destroem recursos humanos e produtivos o que leva a menos desenvolvimento que, por sua vez, aumenta os incentivos para o conflito e assim por diante. Segundo, é razoável afirmar que quanto menos desenvolvido um país for, mais propenso ao conflito sua política doméstica será ou mais sangrentos seus conflitos domésticos serão. Aparentemente, contudo, nenhum dos dois cenários pode ser tomado como garantidos. Quais seriam então as origens dos conflitos intraestatais e do subdesenvolvimento na África Subsaariana? Eles são realmente conectados e

\footnotetext{
${ }^{11}$ Levando em consideração os indicadores utilizados para medir os PMDs.
} 
correlacionados? No caso de resposta afirmativa, pode-se identificar alguma causação entre eles? O processo de falência de Estado é influenciado de alguma forma pelo subdesenvolvimento? Estas são as perguntas que esta pesquisa visa a responder. Agora, que mais de duas décadas se passaram desde o fim da Guerra Fria, é hora de reavaliar a suposta relação entre segurança e desenvolvimento.

A ampliação do conceito de segurança levada ao ponto de incorporar a discussão do desenvolvimento foi duramente criticada. Muitas das críticas destinadas à segurança humana, por exemplo, podem ser aplicadas a qualquer tentativa de ampliação do conceito de segurança internacional. Algumas críticas foram tão intensas que chegaram até mesmo a afirmar que "se a Segurança Humana significa quase qualquer coisa, então ela não significa, efetivamente, nada" e, portanto, tratava-se de um conceito muito amplo para a academia e muito vazio para a política (Paris, 2001, p. 93). Se, por um lado, afirmar que tal conceito é muito amplo para a academia faz bastante sentido uma vez que sua incorporação aos estudos de segurança impunha a estes o risco de perder coesão científica e acadêmica, o mesmo não pode ser dito sobre a questão política do termo, que não é em nada vazio.

A fusão entre segurança e desenvolvimento e os conceitos que daí se derivaram serviram e ainda servem a objetivos políticos claros, principalmente por parte das grandes potências e dos países doadores. O nexo segurança-desenvolvimento esteve presente nas estratégias de segurança de tais países desde o fim da II Guerra Mundial e ainda hoje é um dos assuntos mais importantes para policymakers e analistas preocupados com Estados falidos e frágeis. Presente nas estratégias de segurança nacional dos EUA de 2006 e 2010 e do Reino Unido e adotado também por países como Canadá, Japão e Noruega, tal nexo "assume que a fusão de segurança e desenvolvimento é desejável e produzirá resultados positivos" (Spear \& Williams, 2012, p. 07) uma vez que apresenta uma relação muito menos conflituosa entre o Ocidente e o Sul, pois este enquanto local de vários conflitos tem interesse no desenvolvimento que só pode ser proporcionado por aquele, que tem interesse direto na segurança deste e também representa uma relação muito menos conflituosa entre regimes e cidadãos, já que sendo o desenvolvimento promovido ou facilitado pelo governo, o povo não teria a necessidade de pegar em armas para depor o regime. 
É bastante interessante notar, contudo, que tal fusão e até mesmo a noção de desenvolvimento que lhe serve de base não é consensual bem como é localizada no tempo e no espaço. Ao longo do século XX, foram as principais potências e os países doadores os que mais insistiram na construção desse nexo entre segurança e desenvolvimento, o que acabou sendo apropriado - quando oportuno - pelos países periféricos tais como no caso da I Conferência das Nações Unidas sobre Comércio e Desenvolvimento (UNCTAD) nos anos 1960 e durante a segunda metade da década de 1940, quando países latino-americanos viram neste nexo a oportunidade de ganhar a atenção e investimentos dos EUA que recém haviam lançado o Plano Marshall (Schoultz, 2000). Tal localização espacial não mudou ao longo dos anos, mas recebeu adaptações na forma e no conteúdo. A ampliação generalizada do conceito de segurança e o advento do conceito de Segurança Humana na verdade apenas retratavam "valores progressistas preeminentes dos anos 1990: direitos humanos, direito internacional humanitário e desenvolvimento socioeconômico baseado na equidade" (Suhrke, 1999, p. 266).

A ascensão de tais valores progressistas bancados por um projeto hegemônico só logrou atingir condição central na agenda internacional devido ao sucesso no processo de securitização do desenvolvimento. Evocar a incorporação do desenvolvimento na agenda de segurança internacional por meio de um processo significa admitir que nem sempre desenvolvimento e segurança estiveram interligados. O processo de securitização é construído com base na ideia de que as ameaças não existem objetivamente, ou seja, é resultado de uma construção no discurso de atores poderosos. Nele, as questões de segurança são construídas por meio de "atos de fala" ${ }^{12}$ nos quais o conteúdo do discurso é o próprio ato: ou seja, quando se fala algo, se faz o "algo" (Waever, 1995).

Destarte, o processo de securitização passa primeiro por um estágio no qual o ator apresenta aquilo que crê ser "uma questão tão urgente e existencial e tão importante que não deve ser exposta ao regateio normal da política, mas deve ser tratada de forma decisiva por altos dirigentes antes de outras questões" e depois por um estágio no qual tal questão é entendida por outros atores relevantes e até mesmo pela opinião pública como uma ameaça e, consequentemente, legitimam ações para lidar com a ameaça (Buzan, Waever, \& Wilde, 1998, p. 29). Como será demonstrado, tal processo obteve sucesso e passou a ser incorporado cada vez mais na agenda internacional e nas questões de

\footnotetext{
${ }^{12}$ NT: "speech acts"
} 
segurança internacional de modo a ser até mesmo apropriado pelos países subdesenvolvidos com vistas a adquirir investimentos tanto econômicos como militares. Desta forma, a securitização do desenvolvimento acabou representando também a "radicalização do desenvolvimento", isto é, "a promoção do desenvolvimento tornou-se sinônimo da busca pela segurança" assim como "a segurança tornou-se pré-requisito para o desenvolvimento sustentável” (Duffield, 2001, p. 37).

Foi assim que a política internacional deu sua guinada para o Terceiro Mundo, espaço onde a concentração de conflitos intraestatais e de países subdesenvolvidos é bastante alta. A partir dos anos 1990, a questão dos Estados falidos entrou com força nos estudos de segurança internacional trazendo consigo a percepção de que a segurança e o desenvolvimento estavam intimamente ligados. ${ }^{13}$ Vários índices que se propõem a medir a falência e a fragilidade dos Estados apresentaram variáveis ligadas à presença de violência política e conflitos civis e ao subdesenvolvimento econômico e social e, via de regra, apresentaram como sendo os Estados em pior situação (falência ou fragilidade) aqueles que tinham desempenho fraco nesses quesitos e reforçaram assim "um duradouro interesse dentro da Pesquisa da Paz sobre a relação entre o desenvolvimento e a (in)segurança" (Buzan \& Hansen, 2012, p. 272). ${ }^{14}$

Tal situação levou a uma formulação política e acadêmica de "dois mundos": um centro, que é pacífico, e uma periferia, turbulenta e conflituosa. Neste sentido, acadêmicos, policymakers e até mesmo a opinião pública de muitos países ocidentais passaram a reproduzir o entendimento de que algo estava errado na periferia do sistema internacional e que, portanto, era necessário resgatá-la e assemelhar seus Estados ao máximo daqueles que teriam dado certo. Esta evolução pode ser bem ilustrada em dois

\footnotetext{
${ }^{13}$ O termo "falência" de Estados pode não ser o melhor a ser empregado no processo analisado neste trabalho. Na língua portuguesa, optou-se pela expressão "estado falido" na sua variante brasileira e "estado falhado" em sua variante europeia para descrever o mesmo fenômeno, isto é, para descrever o momento último no qual um Estado deixa de desempenhar suas funções básicas e é tomado por uma onda de violência que o desafia e, por vezes, derrota-o. Neste sentido, este estágio final poderia ser chamado de "colapso estatal" e todos os países que estejam em tal processo ou que corram o risco de entrar em tal dinâmica, de "Estados frágeis". Mesmo ciente do uso não-consensual do termo "falência de Estados", optou-se por usálo uma vez que esta expressão se tornou a referência de tal fenômeno na variante brasileira da língua portuguesa.

${ }^{14}$ Outros índices e rankings existentes que se pode destacar neste sentido são o Bertelsmann Transformation Index (Bertelsmann Stifung); Country Indicators for Foreign Policy (Carleton University); Global Peace Index (Institute for Economics and Peace); Index of State Weakness in the Developing World (Brookings Institution); Peace and Conflict Instability Ledger (University of Mariland); Political Instability Index (Economist Intelligence Unity); State Fragility Index (George Mason University); The Social Progress Imperative; o Global Peace Index; e o Ibrahim Index of African Governance (da Mo Ibrahim Foundation).
} 
estudos de 1994 e 2002. O primeiro, refletindo as preocupações e transformações da agenda de segurança internacional do pós-Guerra Fria, chamava a atenção para uma possível bifurcação no sistema internacional na qual parte do mundo seria habitada pelo "último homem de Hegel e Fukuyama, saudável, bem alimentado e provido de tecnologia" enquanto a outra (maior) parte, seria lócus do "primeiro homem de Hobbes, condenado a uma vida "pobre, desagradável, bruta e curta" (Kaplan, 1994). O segundo, por sua vez, tratava de retratar exatamente aquilo que a comunidade internacional passou a ter como referência da parte do mundo que "deu certo" (Pritchett \& Woolcock, 2002). Seguindo a interpretação que Fukuyama (2011, p. 29) fez deste relatório, pode-se afirmar que o objetivo da comunidade internacional é transformar todo Estado frágil ou falido em uma Dinamarca que, segundo ele, é um "lugar mítico por suas boas instituições políticas e econômicas" e que é "estável, democrático, próspero, inclusivo e tem níveis extremamente baixos de corrupção".

Não é de surpreender que os países da África Subsaariana tenham sido identificados como pertencentes ao grupo que carece de reforma para "se transformar em uma Dinamarca". Afinal, a região ainda é corrente e justificadamente exposta como a mais subdesenvolvida e a mais conflituosa do mundo. Por mais que o continente tenha apresentado importantes taxas de crescimento econômico nos últimos anos, ele ainda é a região com os piores indicadores em todos os índices referentes à paz e ao desenvolvimento: é nele em que estão $70,8 \%$ dos $\mathrm{PMDs}^{15}$; em que $42 \%$ da população global vive com menos de US $\$ 1,25$ por dia $^{16}$; e em que acontecem a maior parte dos conflitos intraestatais do mundo desde $1989 .{ }^{17}$

Por mais que os exemplos recém citados pareçam apontar para a confirmação de um projeto político - conhecido como paz liberal - que visa transformar sociedades disfuncionais e afetadas pela guerra em entidades cooperativas e estáveis que se mantêm por meio de vários fluxos e pontos de autoridade dentro da governança global liberal, é preciso tomar cuidado para o fato de que favorecem análises homogeneizantes da forma

\footnotetext{
1534 países em um total de 48, segundo a UNCTAD (2013).

${ }^{16}$ Segundo o PNUD (2013), a parcela de pessoas que vivem abaixo da linha de extrema pobreza na África Subsaariana caiu de 56,5\% em 1990 para 48,5\% em 2010. Tal dado não pode ser lido de maneira otimista uma vez que o crescimento populacional ocorreu em ritmo muito superior à redução da pobreza: a quantidade absoluta de pessoas vivendo com menos de US\$1,25 por dia cresceu cerca de $40 \%$ no mesmo período, subindo de 289,7 milhões para 413,8 milhões de pessoas.

${ }^{17}$ Themnér e Wallensteen (2014).
} 
que foram apresentados. ${ }^{18}$ Isto é problemático uma vez que há inúmeras e profundas diferenças e heterogeneidade que podem ser vistas não só dentro dos países africanos como entre os países africanos - o que comumente é esquecido. Muitos estudos que se propõem a avaliar e explicar os fenômenos políticos e econômicos na África Subsaariana falham ao considerar os países da região como homogêneos. Apesar de ser verdade que eles têm desempenho inferior ao resto do mundo em vários aspectos, pouco é dito sobre os casos de sucesso no continente. Há vários exemplos que apoiam a elaboração de hipóteses que levem em conta a heterogeneidade entre os países do continente. Primeiro, o fato que dá força para os argumentos pró-heterogeneidade é o já mencionado de que alguns dos países africanos nunca passaram por uma guerra civil desde sua independência mesmo sendo tão subdesenvolvidos quanto vários outros que tiveram. Segundo, dados do Banco Mundial (2015), o crescimento e desenvolvimento econômicos também apontam neste sentido. Entre 1990 e 2012, por exemplo, a renda nacional bruta per capita do Zimbábue cresceu 28,4\%; da África do Sul, 95,4\%; e Moçambique, 221,1\%. Portanto, qualquer hipótese elaborada sobre o estado dos Estados na África Subsaariana deve considerar a grande heterogeneidade entre eles em termos de governança, crescimento econômico, democracia, legitimidade, etc.

Todos esses componentes devem ser postos em um continuum para que se possa avaliar o sucesso e a falência dos Estados. Enquanto é verdade que a Somália talvez represente o caso mais completo e inequívoco de falência estatal, onde pobreza, corrupção, contrabando e conflitos são endêmicos e aparentam ser insolúveis desde a queda de Siad Barre, é verdade também que Botsuana é estável e tem níveis de corrupção extremamente menores, o que favorece o crescimento e o desenvolvimento econômicos (Acemoglu \& Robinson, 2010; 2012; Englebert, 2000a; 2000b). Ambos os países são, portanto, os dois extremos de um mesmo continuum. Entre eles estão países como Togo, Djibuti, Camarões, Gâmbia, Madagascar, Uganda, Suazilândia, Quênia, Zâmbia e outros que não (ainda) vivem uma feliz história de sucesso, mas também não estão (ainda)

\footnotetext{
${ }^{18}$ A paz liberal é um projeto político baseado nas correntes liberais que indicavam como os Estados deveriam estar organizados para constituir um sistema internacional pacífico. Basicamente, essa ideia era composta de três pilares: democracia representativa, respeito a normas internacionais e incentivos materiais para sustentar o compromisso com tais normas (Doyle, 2005). Principalmente após o fim da Guerra Fria, tal projeto passou a ser levado a sério por organizações e doadores internacionais. O objetivo de garantir um sistema internacional pacífico ainda se mantinha, pois entendia-se então que as guerras dentro dos Estados aconteciam em países que não comungavam de tais pilares, principalmente da falta de incentivos materiais (recursos) para que se tornassem adeptos da paz liberal. Assim, o desenvolvimento tornou-se peça chave da paz liberal e a reforma das instituições estatais virou condição para o recebimento dos incentivos.
} 
condenados ao completo colapso estatal. Este talvez seja o motivo mais forte pelo qual não se deve trabalhar a questão da falência estatal sem definições precisas do que compõe um Estado. O método know it when you see it é contra produtivo neste sentido.

As várias tentativas de explicar os conflitos africanos, via de regra, trataram de incluir segurança e desenvolvimento sob o guarda-chuva dos Estados falidos. O que poucas delas fizeram, contudo, foi atentar para o fato de que os Estados podem não estar falidos ou frágeis em absoluto, mas em um ou outro aspecto (Fukuyama, 2011; Miller, 2013). Neste sentido, é possível que o Estado seja frágil ou esteja falido em termos de desenvolvimento econômico e social, mas seja funcional e logre prover segurança contra ameaças externas e, principalmente, contra a desordem doméstica para seus habitantes, por exemplo. A tese da paz liberal não concebe esta possibilidade uma vez que sugere que um Estado só pode ser estável se houver prosperidade econômica e desenvolvimento social. Assim, é importante deixar claro quais e o que são os componentes que constituem o Estado e como eles podem ou não estar relacionados à ocorrência de conflitos na região.

Em termos gerais, autoridade, legitimidade e desenvolvimento têm sido utilizados com o intuito de descrever as características e as funções dos Estados e, destarte, têm sido usado como "réguas" para medir seus sucessos e fracassos. Geralmente, a literatura sobre o desempenho dos Estados e os índices sobre eles que surgiram a partir dela desenvolveram-se na tentativa de avaliar essas três variáveis de modo agregado ou destacando uma ou duas delas sem nomeá-las diretamente. A autoridade, por exemplo, foi apontada como o critério mais básico para a estatalidade: a capacidade que uma entidade política que tem capacidades militares de controlar um determinado território. Tal ideia permite, entre outras coisas, a identificação de Estados de facto e os distingue de grupos armados cuja única atividade que exercem é o crime organizado (Clapham, 1998a; Lemke, 2003). Seguindo esta linha, é possível dizer que a estatalidade básica se resume à autoridade estatal. Além disso, a autoridade também foi enfatizada em vários outros trabalhos como aquela que talvez seja a característica primordial da estatalidade. A definição do que comporia o Estado na sua essência foi diretamente ligada ao controle sobre os meios de destruição por Alexander Wendt (1999, p. 213), que afirmava que este é o fundamento último do poder do Estado, que poderia ser resumido como "um ator organizacional incorporado a uma ordem jurídica institucional que o investe de soberania e um monopólio sobre o uso legítimo da violência organizada sobre a sociedade em dado território". 
Esta última definição introduziu a variável da legitimidade ao invocar o "uso legítimo da violência organizada sobre uma sociedade", resgatando o pensamento clássico weberiano. Ao discutir as fronteiras e a soberania dos Estados, Wendt juntou autoridade e legitimidade. Primeiro, a autoridade deveria ser considerada como uma variável chave já que "um Estado pode ter soberania externa mesmo se não for reconhecido por outros Estados". Este, por exemplo, é o caso de alguns Estados de facto que se transformaram em "Estados-em-espera", isto é, Estados que carecem apenas do reconhecimento da comunidade internacional (ou pelo menos de seus membros mais relevantes) para poderem integrá-la e beneficiar-se de todos os arranjos multilaterais internacionais tais como a proteção e o respeito por sua soberania garantidos pela ONU ou acesso a linhas de crédito em instituições financeiras internacionais como o Fundo Monetário Internacional (FMI) e o Banco Mundial. Este é o caso em que se encontram o Saarauí e a Somalilândia (para citar apenas exemplos da África Subsaariana).

Por outro lado, a legitimidade merece atenção especial uma vez que as fronteiras estatais não podem nunca ser consideradas como assuntos acabados e porque os "Estados são tanto efeitos das fronteiras como são suas causas" (Wendt, 1999, p. 213). Neste caso, a forma com a qual as pessoas lidam com as fronteiras do Estado refletem profundamente a legitimidade do Estado. Usando a terminologia de Holsti ${ }^{19}$, Englebert (2000b, p. 08) referiu-se à "legitimidade horizontal" como "a medida em que existe um consenso sobre o que constitui a organização política ou sobre a comunidade que o Estado compreende" ${ }^{20}$, isto é, o consenso sobre "a definição da comunidade sobre a qual o jugo será exercido" (Englebert, 2000a, p. 11). Neste sentido, países cujos mapas são resultado de políticas expansionistas ou de conquista ou divisão estrangeira carecem de legitimidade uma vez que sua população ressente sua presença naquela polity e que sem dúvida preferiria estar em outro (o próprio) Estado. O nacionalismo e as identidades étnicas podem, portanto, enfraquecer ou fortalecer a legitimidade estatal.

O uso de apenas duas das três variáveis é uma opção adotada mais frequentemente do que pode parecer. Além de Wendt, outros combinaram a legitimidade com outras variáveis com a intenção de avaliar o sucesso e a falência dos Estados. Enquanto Englebert mediu os impactos da legitimidade estatal (tanto horizontal quanto vertical) sobre a capacidade desenvolvimentista do Estado, Rosenau (1989; 1990) combinou

\footnotetext{
${ }^{19}$ Holsti (1996).

${ }^{20}$ N.T.: "organização política" foi o melhor termo encontrado para designar "polity".
} 
autoridade com legitimidade ao analisar como sistemas inteiros mudaram sobre o tempo e turvaram a distinção entre as políticas doméstica e internacional, e autoridade com desenvolvimento quando afirmou que a existência de subgrupos e da interdependência econômica eram ambos fatores que poderiam diminuir a soberania dos Estados ao longo do tempo. A autoridade também foi combinada com desenvolvimento por Jackson e Rosberg (1982) e Jackson (1990). Apesar de terem feito de modo diferente do que fez Rosenau, eles identificaram uma possível relação entre a falta de autoridade do Estado e o subdesenvolvimento na África e no Terceiro Mundo.

Entre aqueles que usaram as três variáveis em conjunto, por exemplo, estão Huntington (1968), Gurr (1980; 1986) e Clapham (1996). Huntington propôs que o desenvolvimento poderia gerar efeitos adversos nas instituições, levando a uma decadência política no Estado. Gurr afirmou que a falência estatal poderia ser apenas o resultado de guerras e revoluções desde que fossem consequências ou gerassem (1) clivagens dentre uma população de determinado país e, por conseguinte, promovessem a aversão à mobilização de materiais e recursos humanos pelo Estado; (2) falta de legitimidade, que poderia levar a um generalizado descumprimento da lei e das decisões governamentais; e (3) habilidade reduzida do aparato estatal para lidar com crises que poderiam surgir no território daquele país. Clapham, por sua vez, identificou três métodos de medição aplicados à estatalidade dos quais dois se referem especificamente ao trinômio autoridade-legitimidade-desenvolvimento: o controle físico sobre um território por seu governo que deveria prover bem-estar para sua população e a "ideia de Estado", isto é, a construção imaginária que a população tem sobre o Estado em que vive.

Usar as três variáveis também foi a escolha de Call (2010); Carment, Prest e Samy (2010); Fukuyama (2011); e Miller (2013). Além disso, eles também compartilham de uma posição comum de que a falência do Estado pode ser multifacetada e pode não ocorrer em todas as variáveis. Call exemplificou isto ao separar os indicadores do Índice de Estados Falidos de 2007 da revista Foreign Policy em três categorias (falta de capacidade, falta de legitimidade e falta de segurança) e identificou que apenas o Sudão, a Somália e a República Democrática do Congo tinham problemas de mesma gravidade em todas elas ${ }^{21}$ enquanto a Guiné Equatorial e o Zimbábue enfrentavam dificuldades de mesma grandeza tanto com a falta de legitimidade quanto com a falta de capacidade ao

\footnotetext{
${ }^{21}$ Para mencionar apenas os países na África Subsaariana. Iraque e Afeganistão completam esta lista.
} 
passo que a Costa do Marfim, o Burundi, Uganda e Maláui sofriam apenas com problemas relacionados à falta de desenvolvimento naquele ano. Carment, Prest e Samy sentiram a necessidade de desagregar as variáveis também. Segundo eles, os conceitos que tentaram compreender todas as supostas características e variáveis criaram um potencial para uma sobreposição entre falência, fragilidade e colapso e encontraram dificuldades em tornar claro o que deveria ser considerado uma característica única compartilhada por todos os Estados. Sua escolha de adotar tais variáveis foi feita de acordo com princípios de aplicabilidade teórica e universalidade.

Fukuyama, por sua vez, forneceu uma profunda pesquisa teórica sobre as origens da ordem política. Mesmo que os estudos sobre a evolução das instituições ainda não tenham identificado o momento e as condições exatas em que a humanidade deixou de organizar-se em tribos e chefaturas e começou a se organizar em organizações políticas que se assemelhavam aos Estados, ele afirma que a ordem política é o resultado natural da evolução da sociedade. Em seguida, tais organizações políticas criaram três instituições fundamentais: o Estado, seguindo a concepção weberiana; o reechtstaat ou o Estado legal, no qual as ações do Estado e do governo são limitadas pela lei; e o governo responsável, subordinado às vontades de seus cidadãos. Uma vez que ele diz que tais instituições evoluíram para atender as ansiedades políticas por regulação, democracia e serviços básicos, não há problema em classificá-los em termos de autoridade, legitimidade e desenvolvimento. Tal como Call e Carment, Prest e Samy, Fukuyama deu exemplos de Estados com desempenhos diferentes em cada instituição/variável. O Afeganistão, por exemplo, teve eleições democráticas desde 2004, mas o Estado é fraco e não consegue impor a lei em boa parte de seu território, enquanto a Rússia é um Estado forte com eleições democráticas no qual seus governantes não se sentem constrangidos pela lei e Singapura é um Estado forte com nomocracia efetiva, mas deixa a desejar quando se trata de responsabilidade democrática.

Os exemplos expostos por Call, Fukuyama e Carment, Prest e Samy são indícios claros de que subdesenvolvimento e conflitos não necessariamente estejam relacionados. $\mathrm{Na}$ verdade, a própria corrente que visa desagregar as variáveis componentes do Estado demonstra essa possibilidade pelo simples fato de existir. Os mais diversos índices de falência e fragilidade de Estado, por exemplo, abrangem diferentes indicadores e auferem-lhes valores que indicam a existência de um descompasso entre eles na grande maioria dos Estados. Em um continuum, a grande maioria dos Estados não só da África 
Subsaariana, mas do mundo, não está nem no extremo da falência total nem no extremo daquele que seria o paraíso na Terra ${ }^{22}$. O gráfico 1 mostra a distribuição dos 178 países medidos pelo índice de Estados frágeis do índice da revista Foreign Policy do Fund for Peace em 2014 entre as categorias 1 (mais perto da falência e do colapso estatal) e 12 (mais perto do modelo idealizado pela revista). Mesmo que haja uma concentração alta dos Estados da África Subsaariana nas primeiras categorias, a distribuição dos seus 49 Estados confirma a afirmação anterior.

Miller (2013, p. 52) talvez seja um autor um pouco fora da curva quando comparado a Fukuyama, Call, Carment, Samy e Prest. Apesar de ter feito duras críticas às tentativas de se construir uma definição única, sua visão sobre o Estado está presente em cinco aspectos. Em suas palavras, "o Estado é uma instituição que invoca com sucesso uma teoria da justiça", reivindicando a autoridade soberana para fazer e impor regras dentro de determinado território e para servir a vida humana ao que se fornece (pretensamente) bens públicos em troca de sua legitimidade.

Gráfico 1 - Distribuição dos 178 Estados avaliados pela Foreign Policy em 2014.

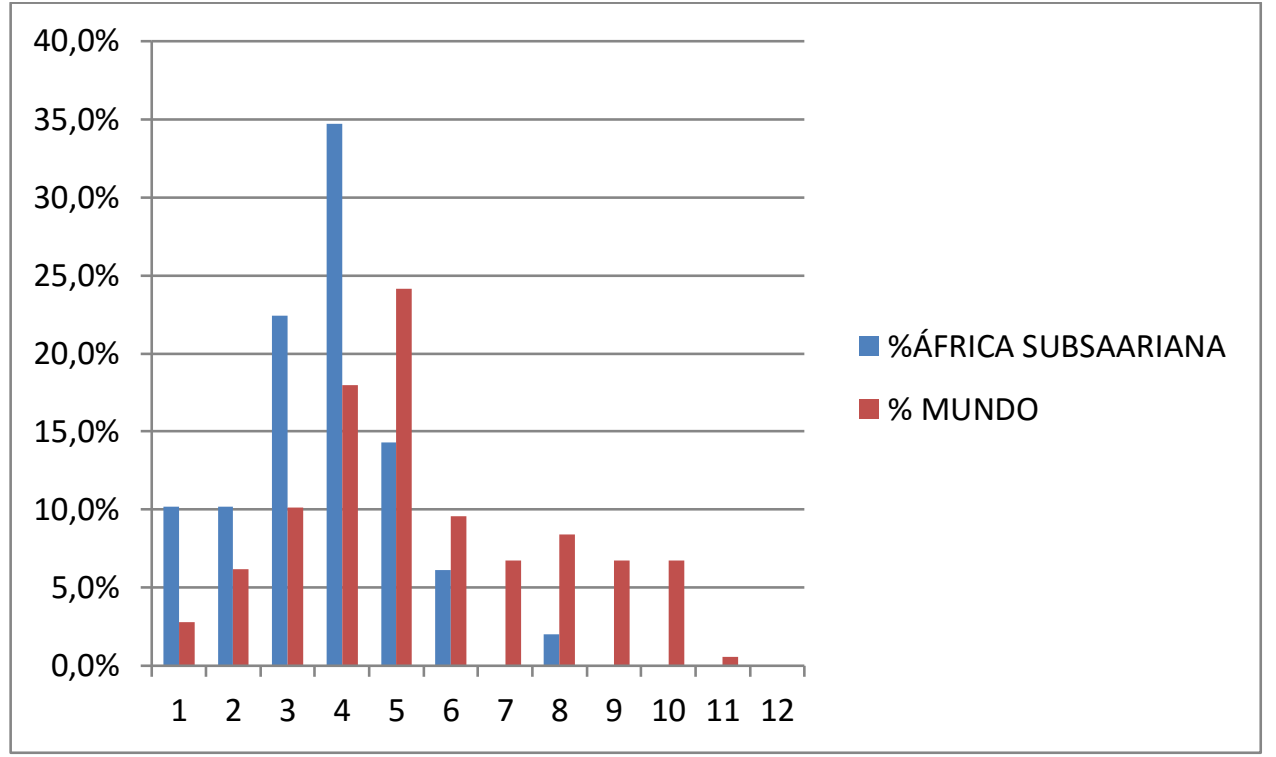

Fonte: Fund for Peace (2014), elaboração própria.

Baseado nesta definição, o autor identificou cinco situações de falência estatal: o Estado anárquico, característica de Estados devastados pela guerra e com grandes

\footnotetext{
${ }^{22} \mathrm{Na}$ verdade, desde que foi lançado em 2005, o índice de Estados falidos da revista Foreign Policy não identificou nenhum Estado na categoria que mais se aproximaria daquilo que ela mesma classificaria como "perfeição".
} 
problemas na segurança; o Estado ilegítimo, quando a população não acredita mais nas reivindicações do Estado; o Estado incapaz, que não cumpre sua parte do contrato social; o Estado improdutivo, que perdeu sua capacidade de agir como ator econômico; e o Estado bárbaro, cujas políticas oficiais violam massivamente os bens e os direitos humanos. Apesar de Miller ter apresentado cinco aspectos nos quais o Estado pode ter fraco desempenho, estes podem ser resumidos nas três variáveis usadas neste trabalho. Primeiro, a conexão entre a variável autoridade (nos seus piores níveis) e o Estado anárquico parece ser óbvia. Estados que não logram impor sua autoridade exigindo o cumprimento da lei e gozando de soberania de facto em seu território estão fadados à anarquia, tal como a Somália. Segundo, os Estados incapaz e improdutivo estão diretamente relacionados com questões de desenvolvimento econômico e social. Por último, apesar de a proteção dos direitos humanos ser uma ação moral imbuída de nobres valores, a violação destes como política de Estado não demonstra que o Estado tenha deixado de ser funcional. Não se pode dizer, por exemplo, que a Alemanha nazista durante o Holocausto e o Império Otomano na época do genocídio armênio fossem falidos, frágeis ou colapsados. Suas ações, inclusive, foram legítimas perante (talvez a maior) parte de suas populações e requereram coesão institucional - algo que é ausente nos Estados falidos.

Apesar de a questão da legitimidade ter sido recentemente inserida na análise do desempenho do Estado, pretende-se aqui analisar primeiramente o papel da autoridade e do desenvolvimento no surgimento dos conflitos intraestatais na África Subsaariana. Por mais frágil e polêmica que esta escolha pode ser, ela foi feita devido a uma premissa e a uma dificuldade. Primeiro, assume-se que a legitimidade - enquanto a aceitação de algo por um grupo de pessoas - pode ser a consequência de Estados com bons desempenhos na autoridade e no desenvolvimento. Até mesmo nos casos em que autoridade pode tornar-se autoritarismo, haverá sempre alguma parcela da população que a aceita como necessária e apoiá-la-á. A comoção popular que ocorreu na Etiópia no ano de 2012 devido à morte do então primeiro ministro Meles Zenawi e a eleição de Muhammadu Buhari para a presidência da Nigéria em 2015 são exemplos de que o autoritarismo pode encontrar aceitação em boa parte da população, ainda que sejam altamente contestados por outros atores políticos.

Zenawi chegou ao poder na Etiópia após a Frente Popular de Libertação do Tigré derrubar o regime de Mengistu Haile-Mariam. Governou a Etiópia entre 1991 e 2012 (ano 
de sua morte) e, neste período, realizou e fraudou as primeiras eleições da história do país. Enquanto opositores lhe acusavam de diversos assassinatos de motivações políticas, a população no geral parece ter aprovado seu governo após o escrutínio: além de altíssimas taxas de crescimento econômico durante os últimos cinco anos de seu governo, a Etiópia também atingiu e ultrapassou com sobras alguns dos Objetivos de Desenvolvimento do Milênio ao diminuir em 2/3 a mortalidade de crianças com menos de cinco anos de idade e garantir o acesso a água potável a $57 \%$ da população. Além disso, a própria ONU assume que a os esforços da Etiópia no que tange às outras metas estão em ritmo satisfatório $^{23}$. Por sua vez, o presidente da Nigéria, Muhammadu Buhari legitimou muitas ações tomadas durante seu governo ditatorial entre 1984 e 1985, no qual vários opositores e críticos do governo foram presos, com sua eleição em 2015. Destituído de seu primeiro mandato em 1985 por outro golpe de Estado, Buhari carregou consigo a imagem de um militar pulso firme que não aceitava opiniões contrárias, o que lhe prejudicou nas eleições presidenciais de 2003, 2007 e 2011. Recentemente, apesar do crescimento econômico no país promovido durante o governo do presidente Goodluck Jonathan, a Nigéria tem enfrentado dificuldades no que diz respeito à segurança com seguidos atentados e ataques do grupo extremista Boko Haram. Foi exatamente empunhando a bandeira de combate a tal grupo que Buhari conseguiu ser eleito presidente do país, desta vez aproveitando-se de sua fama de militar pulso-firme.

O segundo motivo pelo qual a legitimidade não está no centro deste estudo é o fato de que abundam formas de medir a legitimidade estatal e fontes com dados sobre isso abundam, dependendo da perspectiva adotada. Há uma variável crucial na África Subsaariana cujos efeitos sobre a legitimidade estatal são realmente difíceis de medir: a questão das etnias. Apear de Englebert (2000a; 2000b) e Hoslti (1996) terem criado um mecanismo interessante para fazê-lo, seu método é falho uma vez que não captura mudanças com o passar dos tempos, tratando as etnias e as identidades estaticamente. É bem possível que a legitimidade tenha seu papel na origem dos conflitos intraestatais na África Subsaariana. Seu papel e sua relação com as variáveis autoridade e desenvolvimento serão ainda analisados com o devido cuidado, mesmo que de forma secundária.

\footnotetext{
${ }^{23}$ United Nations Country Team Ethiopia (2012); United Nations Economic Commission for Africa, African Union, African Development Bank e United Nations Development Programme (2014).
} 
Uma das maiores dificuldades para conseguir definir autoridade e desenvolvimento em uma discussão sobre espaços não-ocidentais é justamente a forte crítica pós-colonialista que defende que o Terceiro Mundo tem suas especificidades que são, por sua vez, incompatíveis com a necessidade de um Estado forte como referência (Ayoob, 1984; 1995; 1997). O estadocentrismo nos estudos de Relações Internacionais e, mais especificamente, de paz e segurança internacionais se baseava em uma experiência europeia e reproduzia assim uma "geoepistemologia" que fora expandida para a análise de outras regiões do globo. Foi a partir da análise feita por Tilly (1990) sobre a formação dos Estados europeus e sua relação com a guerra - resumida na famosa frase "o Estado fez a guerra e a guerra fez o Estado" - e de sua aplicação para a análise de realidades distintas que muitas das críticas sobre o estadocentrismo e sobre os estudos tradicionais de segurança internacional se organizaram.

Seguindo à risca a máxima sobre a relação entre guerra e a formação estatal, seria simples afirmar o motivo da situação notória dos Estados da África Subsaariana. A falta da experiência capital da guerra entre Estados naquela região teria dificultado processos de coesão social e que induziriam a organizações administrativas semelhantes àquelas dos Estados europeus. Um primeiro problema sobre esta leitura é que a região do Chifre da África, por exemplo, é-lhe um contrafatual. A região apresentou ao longo do século XX duas das raríssimas guerras interestatais de todo o continente (Guerra de Ogaden, 197778; e Guerra Etio-Eritreia, 1998-2000) e não se assemelha em nada aos resultados obtidos na Europa devido à experiência capital da guerra (Clapham, 2000). Outro problema com tal leitura é que o sistema de Estados europeu se formou com uma "forte identificação com a segurança do Estado com a segurança de seus cidadãos" e não considera que o próprio Estado e seu regime podem ser a ameaça aos seus cidadãos (Krause, 1996) ${ }^{24}$. Esta crítica defende, entre outras coisas, que a existência de Estados falidos se deve aos efeitos da colonização tardia e que tal conceito constituiu-se na construção discursiva das identidades. Neste sentido, procedeu-se a construção política e acadêmica do "outro", do não-ocidental como subdesenvolvido e falido. Estas identidades inferiores criadas no Ocidente assumiram, entre outras coisas, a existência de culturas pré-coloniais imutáveis que podem ser mobilizadas pelo Ocidente e pelas elites não-ocidentais (Mamdani, 1996; 2001; Dunn, 2001; Barkawai \& Laffey, 2006).

\footnotetext{
${ }^{24}$ Ênfase no original.
} 
Além desta, também é forte a crítica que alerta para o fato de os estudos de segurança geralmente trabalharem com base em uma suposição de que há um conceito universalmente aceito sobre segurança e que afirma que o objetivo da segurança pode não estar ligado à sobrevivência dos indivíduos ou dos Estados. Segundo esta linha de pensamento, há importantes diferenças não só na forma em que as sociedades se organizam como também constituem seus princípios políticos essenciais tais como e violência, governança e identidade. Neste sentido, permite-se afirmar que o termo "segurança" não deve ser identificado como a "lógica da segurança" das concepções realistas (Buzan \& Hansen, 2012).

As abordagens pós-coloniais, então, chamam a atenção para as especificidades do Estado nos espaços não-ocidentais e daquilo que talvez seja a sua primeira responsabilidade (a segurança). Ora, ao destacar tais especificidades, elas dão ênfase à existência de formas indígenas e mistas de organizações sociopolíticas e relativizam a ideia de Estados falidos e suas causas étnicas e culturais. Denunciam também que os fundamentos aistóricos e normativos do conceito "falência de Estado" demonstram uma linguagem evolutiva e, muitas vezes, acabam tratando as culturas como fator causal do atraso dos Estados africanos quando o real problema seria que "não é qualquer Estado que está colapsando; é especificamente o que restou do Estado colonial na África que está em colapso" (Mamdani, 2001, p. 652).

A rejeição à universalidade do tipo-ideal do Estado ocidental não deve ser levada às últimas consequências. Ainda que recorrentemente o desempenho do Estado seja medido tomando-o como referência, é importante levar em conta que processos políticos indígenas e formas mistas de governo são capazes de restaurar a ordem doméstica e garantir a segurança externa das organizações políticas, tornando-as assim Estados. A questão, portanto, não é se o desempenho dos Estados deva ser medido tomando exclusivamente como referência a experiência ocidental ou que não deva ser medido uma vez que todas as referências devem ser relativizadas. Trata-se de admitir que os Estados (ocidentais ou não) comungam de certas características e é exatamente isso que permite fazer uma avaliação de seus desempenhos. Em outras palavras, é possível afirmar que os Estados tradicionais e contemporâneos na África compartilham de um rol de características semelhantes ao de seus congêneres alhures: todos eles, por exemplo, apresentaram e apresentam relações hierárquicas entre governantes e governados bem como a obrigação de garantir determinada ordem doméstica e a segurança contra ameaças 
externas. Note-se, contudo, que dentre tais características não está a promoção do desenvolvimento e do bem-estar.

A autoridade é uma destas características e talvez seja aquela de trânsito mais fácil entre as correntes de pensamento que visam a avaliar os Estados. Em termos gerais, ela pode ser entendida como "a capacidade de resolver conflitos e estabelecer regras com base em seu status dentro da hierarquia" (Fukuyama, 2011, p. 49). Esta é de certa forma a perspectiva de Morgenthau (1962), Huntington (1968), Gurr (1980) e Merry (1987). Todos eles entendem que a força e a fraqueza dos Estados se medem por sua habilidade de administrar crises, independente do fato de terem surgido endógena ou exogenamente. Isto não significa, contudo, que as crises e a violência sejam necessariamente ruins. Uma vez que as instituições costumam ser resistentes a mudanças, a violência pode ser necessária para romper o equilíbrio institucional que é responsável por mazelas da população. Foi desta forma que ocorreram a Revolução Francesa e a chamada Primavera Árabe. Estas visões de autoridade não são mutuamente excludentes, mas complementares. Elas incluem a noção weberiana de soberania e Herrschaft, considerando a segurança pública, a estabilidade política e as regras e normas que regulam e condicionam as vidas dos indivíduos em dado território. Este é o motivo pelo qual a estatalidade é conceituada como "uma estrutura de regras institucionalizada com a capacidade de governar com autoridade (Herrschaftsverband) e em controlar legitimamente os meios de violência (Gewaltmonopol)" (Risse, 2011, p. 04).

Destarte, a autoridade estatal será definida como a capacidade de um estado promulgar ou outorgar legislação que será cumprida pela população e de garantir a ela e demais atores políticos dentro de seu território um ambiente seguro e estável. Neste sentido, ela é entendida como a resultante da efetividade da governança estatal, da nomocracia e da ausência de violência política. Quanto à efetividade da governança, elas compreendem não apenas as percepções sobre a qualidade dos serviços públicos, mas principalmente sua independência com relação a pressões políticas. A qualidade e o excesso de burocracia também entram nesta avaliação uma vez tanto aquelas quanto estas afetam diretamente a capacidade de um Estado em formular e implementar políticas e regras. Do mesmo modo, a questão da nomocracia mede a percepção e a confiança da população nos agentes políticos e de que também eles estão sujeitos às regras existentes. Ela é composta pela exigibilidade dos contratos, pela velocidade dos processos judiciais e a independência do Judiciário vis-à-vis o Estado e grupos política e economicamente 
poderosos, pela confiança da população nos serviços de segurança (polícia, por exemplo) e pelo grau de segurança que pessoas e bens encontram no Estado. Por fim, a estabilidade política e a ausência de violência política são percebidas mensura a probabilidade de trocas de governo abruptas, violentas ou contra as regras existentes e o uso de violência como instrumento político tanto contra o Estado quanto pelo Estado contra seus cidadãos. Neste sentido, a forma com que protestos são organizados e o modo com que o Estado lida com eles (reprimindo-os ou aceitando-os) compõem esta variável juntamente com a percepção de que o governo está vulnerável a sofrer golpes de Estado, de que um atentado terrorista pode acontecer a qualquer momento e de que conflitos sociais podem eclodir. Esta percepção sobre a autoridade estatal e os indicadores usados para medi-la estão de acordo com essa definição sobre a autoridade estatal e deixam pouca margem para crítica justamente por sua universalidade. É muito difícil imaginar qualquer sociedade na história que tenha se oposto a estes princípios. A divergência pode acontecer, na verdade, nos meios usados para atingi-los.

O desenvolvimento, por sua vez, é um conceito com definições controversas que variam desde o crescimento econômico até o bem-estar da população. No geral, países com alto PIB ou renda per capita são aqueles capazes de fornecer bem-estar a seus cidadãos uma vez que podem pagar por bons sistemas de saúde, educação de alto nível e infraestrutura. $\mathrm{O}$ problema reside nos países com alta renda per capita e, inversamente, população pobre que não tem acesso a serviços básicos fornecidos tanto pelo Estado quanto pelo mercado. Um bom exemplo para ilustrar tal situação é Angola, cujas rendas provenientes do petróleo aumentaram a renda bruta nacional per capita em $1000 \%$ entre 1996 e 2011 e está previsto que deixe a categoria dos PMDs (um conceito muito mais amplo que mede bem-estar e pobreza também) em $2021 .^{25}$

Por causa desta visão estreita que igualou desenvolvimento e crescimento econômico, muitos se referiram ao primeiro como capacidade desenvolvimentista ou simplesmente capacidade. Como já dito, alguns peritos construíram seus índices e procederam suas análises com esta nomenclatura. No geral, o termo capacidade tem sido preferido quando se fala do desempenho dos Estados uma vez que "se refere à mobilização de recursos públicos para propósitos produtivos e defensivos" (Tikuisis, Carment, Samy, \& Landry, 2014). Além disso, tal termo é geralmente entendido como a

\footnotetext{
${ }^{25}$ Com a aprovação da resolução da Assembleia Geral da ONU A/RES/70/253 de 12 de fevereiro de 2016, Angola deixará de ser um dos PMDs cinco anos após a aprovação da mesma.
} 
implementação bem-sucedida de política e a presença de uma burocracia eficiente que está subordinada à lei (Englebert, 2000a). Estas visões são, entretanto, muito amplas e fracamente definidas. A disposição de constranger comportamentos oportunistas que beneficiariam apenas um específico grupo e de subordinar burocratas e elites à lei é mais diretamente ligada à autoridade e à legitimidade do que à capacidade estatal.

Englebert (2000b) ligou o desenvolvimento e a capacidade ao enfatizar a necessidade dos governos em implementar políticas para o crescimento econômico e para gerar boa governança. Esta capacidade desenvolvimentista, segundo ele, é crucial para criar um ambiente que favoreça o crescimento e as iniciativas privadas voltadas para o mercado no sentido de gerar investimentos em novos negócios. Ao fazê-lo, ele e Acemoglu e Robinson (2012) concordaram com o papel da qualidade institucional na promoção do crescimento econômico e das condições que lhe permitem. Em suma, seus argumentos e a forma como definem boa governança e qualidade institucional expõem uma conexão profunda entre legitimidade e capacidade, mas não leva em conta a qualidade de vida, uma vez que assumem a distribuição de renda como uma consequência natural destes padrões institucionais e do crescimento econômico.

$\mathrm{O}$ que as visões supramencionadas provavelmente não consideraram ou negligenciaram foi o fato de que há - conforme advogado por agências e instituições internacionais como o PNUD e o Banco Mundial - muitas outras variáveis que podem influenciar o crescimento econômico e as melhorias sociais, tais como a alfabetização, a saúde e o bem-estar. Neste sentido, o termo desenvolvimento é preferível uma vez que compreende esta e outras variáveis que influenciam e são influenciadas pelo crescimento econômico e pela capacidade estatal. Carment, Prest e Samy (2010), apesar de utilizaramse do termo "capacidade", fizeram um importante movimento para a utilização de uma visão mais abrangente sobre esta questão. Além da alfabetização, saúde e bem-estar, eles também incluíram a demografia e a disponibilidade de recursos como terras aráveis e água potável. Ainda que este alargamento do conceito seja importante, ele ainda carecia de critérios para torná-lo mais amplo e completo. Se for entendido como algo tão multifacetado quanto os indicadores que compõem os Objetivos de Desenvolvimento do Milênio (ODM) e a classificação dos PMDs, que são estreitamente relacionadas e se aproximam da renda per capita, dos recursos humanos e da vulnerabilidade econômica, o desenvolvimento caracteriza-se então como uma variável crucial na análise do desempenho dos Estados. Como se verá no próximo capítulo, é esta última a perspectiva 
adotada pela comunidade internacional e, por isso, será a adotada neste trabalho. Da maneira, o desenvcolvimento

Para levar a cabo este estudo e identificar a origem dos conflitos intraestatais na África Subsaariana, os desempenhos dos estados desta região serão medidos com base na autoridade e no desenvolvimento. Para tal fim, a região foi definida como todo o continente africano, subtraindo-se Argélia, Egito, Líbia, Marrocos e Tunísia. Apesar de haver um movimento intenso de africanistas para que se trate o continente como um todo, é inegável que estes cinco países tiveram experiências com relação a fronteiras, desenvolvimento, estabilidade e geopolítica muito diferentes das de seus congêneres ao sul do Saara. Esta delimitação espacial já fora utilizada por Herbst $(2000)^{26}$, Englebert (2000a; 2000b; 2009) e Moss (2011) e aparenta ser a mesma utilizada por Acemoglu e Robinson (2010). Além disso, a ONU organiza os dados estatísticos de seus Estadosmembros praticamente da mesma maneira ${ }^{27}$. A única diferença é que ela considera o Sudão como “África do Norte”. Este trabalho, contudo, considerá-lo-á como um país da África Subsaariana, seguindo as classificações dos outros autores e de outras organizações internacionais, tal como o Banco Mundial.

Além disso, aplicaram-se análises quantitativa e qualitativa neste estudo justamente com o intuito de dar maior robustez aos resultados. Quanto à primeira, excluíram-se países como Eritréia, Etiópia, São Tomé e Príncipe, Somália, e Sudão do Sul devido a uma impressionante falta de dados. Isto foi um problema uma vez que alguns deles constituem casos de falência estatal ou tiveram sérios conflitos intraestatais. Sua falta na análise poderia afetar significativamente os resultados. Para alguns Estados e indicadores, simples regressões lineares preencheram as pequenas lacunas existentes. Para aqueles, contudo, a falta de dados foi tão grande que as regressões teriam pouca utilidade ou validade. A análise quantitativa, por tanto, é limitada mas oferece um bom indicativo de que desenvolvimento e segurança não caminham necessariamente juntos e de que a autoridade estatal é a variável determinante para a paz ou a guerra nos Estados africanos. A análise qualitativa, por outro lado, é mais forte e visa a, primeiro, suprimir

\footnotetext{
${ }^{26} \mathrm{Herbst}$ exclui os países insulares da África Subsaariana ao afirmar que estes tiveram experiências distintas no que tange à difusão de poder sobre a distância e às fronteiras Nacionais. Englbert (2000b), em contrapartida, oferece evidências suficientes que demonstram que não há um "efeito ilha" ou diferenças nestes países que sejam estatisticamente significantes quando se trata da relação entre a legitimidade dos Estados e do desenvolvimento.

${ }^{27}$ United Nations Statistic Division (2013).
} 
os problemas causados pela falta de dados dos países mencionados acima e, principalmente, explorar a causalidade entre conflitos intraestatais e o baixo nível de autoridade estatal.

Coletaram-se dados de três principais fontes: o Banco Mundial, a FERDI (Fondation pour les Études et Recherches sur Le Développment Internationial) e o Uppsala Conflict Data Program. Os dados disponíveis sobre a autoridade compreenderam os anos entre 1996 e 2011. Para esta, as fontes já haviam definido valores máximos e mínimos que apenas foram convertidos para a escala entre 0 (pior) e 1 (melhor). Para o desenvolvimento, os dados foram convertidos para uma escala semelhante à da autoridade. No entanto, os dados disponíveis sobre este eram bem mais abrangentes, compreendendo o período selecionado entre 1990 e 2011. Quando foi necessário comparar os valores das duas variáveis, utilizou-se o menor intervalo de tempo. Para ambas as variáveis, o dado de determinado país em determinado ano conta como um caso e, portanto, as amostras de autoridade e desenvolvimento são compostas respectivamente por 704 e 968 casos. Quando foi necessário, os casos foram divididos em quatro categorias de acordo com seus valores: A para valores maiores ou iguais a 0,75 ; B para valores menores que 0,75 e maiores ou iguais a 0,5; C para valores menores que 0,5 e maiores ou iguais a 0,25 ; e D para valores menores que 0,25 . Na questão do desenvolvimento, estas categorias foram criadas com o intuído de fortalecer a ideia de heterogeneidade entre os países da África Subsaariana e, assim, representam uma subdivisão uma subdivisão nos grupos dos PMDs e dos não-PMDs: todos os países classificados como D e a grande maioria dos classificados como C estavam entre os PMDs. No que tange à autoridade, essa subdivisão representa a heterogeneidade entre os grupos de países que foram ou não palco de conflitos intraestatais durante o período analisado. Nenhum dos países classificados como A ou B sucumbiram à guerra civil. Além disso, este estudo entende os conflitos intraestatais como aqueles em que ao menos uma das partes foi o governo do país em questão e de acordo com a sua ocorrência.

Para chegar às respostas sobre a origem dos conflitos intraestatais africanos e demonstrar que estes não são vinculados aos níveis de desenvolvimento dos Estados, os próximos capítulos procederão à análise sobre a relação entre eles e os níveis de autoridade e desenvolvimento nos Estados da África Subsaariana. Este trabalho está dividido em duas partes. A primeira (capítulos 1 e 2), mais geral, tem como objetivo dar um panorama sobre como a fusão entre segurança e desenvolvimento atendeu mais a fins 
políticos do que retratou de fato relações de causa e consequência no mundo, com um óbvio enfoque na África Subsaariana. A segunda (capítulos 3, 4, e 5), por sua vez, debruçar-se-á sobre os Estados da África Subsaariana organizados em grupos de acordo com o nível de desenvolvimento e a ocorrência de guerras civis em sua história independente. Ao fazê-lo, esta parte objetiva ilustrar os argumentos apresentados na seção anterior, mas principalmente demonstrar com mais detalhes como os fatores elencados estão relacionados com a paz ou a guerra nesses países.

No primeiro capítulo, demonstrar-se-á como a fusão entre segurança e desenvolvimento foi criada a partir da construção do discurso neoliberal que securitizou o bem-estar dos indivíduos dos Estados e as condições internas a este. Nele, será feita uma análise na história do século XX a fim de demonstrar que pelo menos desde o fim da II Guerra Mundial já havia uma tentativa de vincular as agendas de desenvolvimento e de segurança e como cada tentativa foi tratada pelos Estados dos chamados Primeiro e Terceiro Mundos. Além disso, objetiva expor como a proposta de fusão obteve sucesso principalmente a partir do advento da hegemonia neoliberal nos anos 1990 e concluirá afirmando que há problemas nos conceitos e nas percepções sobre segurança e desenvolvimento que impedem o estabelecimento de uma relação causal entre eles.

O segundo capítulo apresentará dados sobre o desenvolvimento e a ocorrência de conflitos intraestatais na África Subsaariana a fim de demonstrar que não há relação entre ambos. Seu principal argumento será de que são as variações nos níveis de autoridade estatal as responsáveis pela eclosão daquele tipo de conflitos nos Estados da região e que tal variável tem, na maioria dos casos, dinâmica oposta ou independente à do desenvolvimento. Deste modo, aspectos que interferem direta ou indiretamente na autoridade estatal serão apresentados. Além do tamanho dos Estados e da distribuição de sua população sobre o território, aspectos pré-coloniais, coloniais e pós-coloniais que influenciaram na construção das instituições estatais e, consequentemente, na autoridade estatal na região serão discutidos inicialmente para serem aprofundados posteriormente.

O terceiro capítulo trabalhará especificamente a questão dos Estados africanos classificados pela ONU como membros do nada honroso grupo dos PMDs e que nunca tenham passado por guerra civil nem conflitos não-estatais. Com este capítulo, pretendese demonstrar que a paz em sua história não é devida ao desenvolvimento econômico e social do país, mas sim à autoridade do Estado, em boa parte favorecida pela geografia e 
pela manutenção de práticas pré-coloniais na sua governança. Será demonstrado que, com exceção da Tanzânia, o processo de incorporação e acomodação dos líderes tradicionais nas instituições estatais muito facilitou a projeção do poder e consolidação da autoridade estatal nos rincões mais afastados do território estatal. Especificamente nele, procurou-se demonstrar como o subdesenvolvimento não foi capaz de desgastar a autoridade do Estado.

O quarto capítulo seguirá o mesmo roteiro, porém aplicados aos oito não-PMDs do continente que nunca passaram por guerra civil ou conflitos não-estatais. Além de expor a óbvia diferença com relação aos países do capítulo anterior com relação ao desenvolvimento, demonstrará as inúmeras semelhanças que ambos os grupos têm com relação aos fatores que compõem a autoridade estatal e como este segundo grupo têm alguns destes de modo mais intenso e profundo, o que justifica seus níveis mais elevados de autoridade. São exatamente essas diferenças na questão do desenvolvimento e as semelhanças no que tange à autoridade que sustentam o argumento de que o subdesenvolvimento não culmina na falência estatal.

O quinto capítulo, por fim, selecionou quatro países que tiveram correlações altas e positivas entre autoridade e desenvolvimento entre 1996 e 2011 e mesmo assim tiveram guerra civil durante esse período. Analisar a forma como os conflitos de Angola, República do Congo, Libéria e Ruanda foram encerrados demonstram uma predileção dos atores locais e externos envolvidos no processo de reconstrução do Estado pelos mecanismos de autoridade estatal. A história dos conflitos destes países demonstra que os próprios acordos de paz (tendo sido eles cumpridos ou não) visavam à reconstrução de instituições que garantissem a ausência de violência política e terrorismo, a eficácia da governança e a nomocracia - exatamente os três componentes da variável autoridade. Neste sentido, procurou-se demonstrar que o subdesenvolvimento não teve condições de potencializar os conflitos em locais de baixa institucionalização estatal.

Após isto, conclui-se que a autoridade estatal tem papel primordial na estabilidade e paz (ainda que negativa) nos países da África Subsaariana. Desta forma, as poucas sugestões de políticas feitas neste trabalho reforçarão a necessidade de se focar na estrutura dos Estados, uma vez que os conflitos surgem quando a resultante de sua força e da força da agência pende no sentido da segunda. Ainda, será demonstrado que a 
legitimidade do Estado desempenha papel importante no fortalecimento da autoridade estatal, o que era esperado em muito menor grau no início desta pesquisa. 
PARTE 1 - A relação entre autoridade, desenvolvimento e conflitos na África Subsaariana 


\section{A criação histórica de uma fusão forçada}

A ideia da fusão entre segurança e desenvolvimento ganhou maior visibilidade, tornou-se moda nos principais círculos políticos e acadêmicos no imediato pós-Guerra Fria e ganhou nova roupagem após os atentados às Torres Gêmeas em 2001 por meio de uma perspectiva abrangente e genérica sobre os novos conflitos e para os Estados falidos que apontava para a segurança como a exclusão da ameaça e da violência física ao indivíduo e para o desenvolvimento como o crescimento econômico dos Estados e da supressão das necessidades materiais dos indivíduos. O entendimento de que esses dois conceitos poderiam estar íntima e causalmente ligados pré-datava em quatro décadas os marcos considerados inauguradores desta ampliação do conceito de segurança. No decorrer do século XX, tudo indica que a fusão entre segurança e desenvolvimento não passou de uma mera imposição política que viesse a obedecer a interesses de diferentes Estados, tendo no geral, prevalecido o das potências.

\subsection{A securitização do desenvolvimento}

Desde o fim da II Guerra Mundial até os tempos contemporâneos, a questão do desenvolvimento dos Estados se inseriu na agenda internacional sempre visando ao objetivo maior da segurança internacional. Desde então, Estados periféricos e com problemas de desenvolvimento se tornaram preocupação para as grandes potências (principalmente ocidentais) como possível fonte de ameaça, variando desde uma possível adesão ao bloco soviético nos tempos de Guerra Fria até a possibilidade de serem portos seguros para grupos terroristas na virada do século. Com algumas diferenças, todos defenderam uma ideia comum de desenvolvimento que destacava o bem-estar e as liberdades individuais. Neste sentido, é correto afirmar, por um lado, que a ideia do desenvolvimento social permeia a evolução histórica do debate da fusão entre desenvolvimento e segurança enquanto, por outro lado, o entendimento do subdesenvolvimento como ameaça ainda refletia as preocupações estratégicas da Guerra Fria e só foi trazer uma concepção mais ampla de segurança a partir dos anos 1990. Assim, se antes o desenvolvimento era importante para evitar que países sucumbissem às “ameaças" comunistas, ele passou a ser imprescindível a partir dos anos 1990, pois era "a coisa certa a ser feita" e porque havia um interesse comum a todos os Estados do globo (DFID, 1997). 
Tal perspectiva já podia ser verificada logo no fim da II Guerra Mundial, principalmente nos planos de assistência econômica promovidos pelos EUA sob o quadro da Doutrina Truman, identificando o comunismo como a grande ameaça à segurança não só dos Estados europeus, mas também internacional. Para o então presidente americano Harry S. Truman, a ajuda militar e econômica para países devastados pela guerra era condição sine qua non para impedir que sucumbissem àquela que, de acordo com a política externa americana daquele momento, era a maior ameaça à paz e à segurança internacional. Garantir a reconstrução e a estabilidade econômica desses países era, portanto, uma medida de segurança. Inicialmente, a preocupação principal de Truman era com as crises na Grécia e na Turquia, as quais se encontravam completamente destruídas e sem fundos para qualquer tentativa de reconstrução. Para ele, caso ambos os países não recebessem ajuda imediata, eles forçosamente sucumbiriam à "doença do comunismo", o que poderia se alastrar para todo o resto da Europa.

Em uma metáfora que identificou a liberdade na Grécia como um paciente e qualificou as ambições soviéticas sobre aquele país como a doença, Truman denunciou a situação daquele país ao congresso americano alegando que "uma minoria militante, que explora a miséria e as necessidades humanas, foi capaz de criar um caos político que, até agora, tornou a recuperação econômica impossível" (Ivie, 1999, p. 579). Na fala do então presidente americano, a relação de necessidade e miséria humanas com regimes não afeitos à paz se apresentava sempre como a preocupação de uma metástase daquela doença, isto é, que o comunismo pudesse se espalhar pela Europa ameaçando assim os interesses e a segurança americanos. Não à toa, na conclusão de sua mensagem ao Congresso na qual pedia a autorização para prover fundos à Grécia e à Turquia, Truman afirmou que "as sementes dos regimes totalitários são alimentadas pela miséria e pela necessidade" e que "se espalham e crescem no solo mal da pobreza e dos conflitos" (The Avalon Project, 1947).

A ideia de que pobreza e miséria poderiam representar as fontes de uma ameaça à segurança dos EUA foi também reproduzida no extenso nome oficial do ato que institucionalizou e expandiu o Plano Marshall. Imbuído na Doutrina Truman, o "Ato para promover a paz mundial e o bem-estar geral, o interesse nacional, e a política externa dos Estados Unidos, através de medidas econômicas, financeiras e outras medidas necessárias para a manutenção das condições no exterior em que as instituições livres podem sobreviver e ser consistentes com a manutenção da força e a estabilidade dos Estados 
Unidos" 28 antevia a relação entre bem-estar e a paz mundial expandindo a ideia inicial de auxílio à Grécia e à Turquia para o resto da Europa e para a Ásia como forma de contenção da ameaça soviética.

Em seu texto, a relação entre a paz duradoura e o bem-estar geral foi explicitada tanto para a Europa quanto para a China. Constava que "a situação existente na Europa põe em perigo o estabelecimento de uma paz duradoura, e do bem-estar geral e do interesse nacional dos Estados Unidos" e que a cooperação econômica com e na Europa era essencial para uma paz duradoura e prosperidade. $\mathrm{O}$ mesmo constava sobre a situação chinesa, para qual o ato repetiu o texto citado acima apenas substituindo Europa por China. No entanto, para este segundo, o ato foi além e declarou que era a política dos EUA encorajar a República da China a "envidar esforços comuns sustentáveis que rapidamente atingirão a paz interna e a estabilidade econômica na China, que são essenciais para a paz e a prosperidade duradouras no mundo" (The Marshall Foundation, 1948, p. 137 e 158).

Ainda que o entendimento de ameaça à paz e à segurança estivesse sendo retratado como uma ameaça aos interesses dos EUA, é importante ressaltar que já neste momento havia por parte dos principais formuladores de política americanos uma ideia de que a normalidade econômica (não comunista) e o bem-estar eram condições-chave para a estabilidade política e a segurança internacional. Isto é, a própria política de contenção da ameaça soviética entendia que fatores internos aos Estados poderiam ser uma ameaça à paz internacional e que, portanto, era dever dos EUA garantir o restabelecimento da "saúde econômica" dos Estados aliados e de localização estratégica para seus interesses. Como o próprio Secretário de Estado George Marshall afirmou, "é lógico que os Estados Unidos devem fazer qualquer coisa que puderem para assistir no retorno da saúde econômica normal do mundo, sem a qual não pode haver estabilidade política ou paz garantida" (Secretary of State George Marshall Announces a Plan to Save War-Ravaged Europe from Descending into "Chaos", 1999, p. 165).

O Plano Marshall e a Doutrina Truman parecem ter sido, então, as primeiras ocasiões em que foi feita uma ligação direta entre a reconstrução econômica doméstica e as estabilidades políticas doméstica e internacional. Ainda que o termo desenvolvimento não tenha sido diretamente abordado nos documentos e discurso acima demonstrados, a

\footnotetext{
${ }^{28}$ Nome oficial do ato que instituiu o Plano Marshall.
} 
ideia de reconstrução econômica (crescimento econômico) e o bem-estar geral (supressão das necessidades materiais dos indivíduos) são bem próximos de um entendimento mais amplo e hodierno de desenvolvimento, mesmo estando bastante ligado com o mercado de consumo como foram à medida do possível expandidos e implementados para alhures (Spear \& Williams, 2012; Cypher \& Dietz, 2004).

Nos meios multilaterais, as tentativas de vincular segurança e desenvolvimento foram ganhando força conforme o Terceiro Mundismo se apresentava como alternativa a modelos de desenvolvimento ligados à governança global liberal e ao capitalismo e também ao Socialismo Internacional. O movimento apresentava uma perspectiva diferente de como o sistema internacional deveria ser organizado e de como a riqueza deveria ser distribuída, em clara oposição à perspectiva liberal que entendia não haver ligação entre pobreza e riqueza, sendo a primeira consequência de uma "complexa rede de causas relativas" (Duffield, 2001, p. 24)

Baseado na chamada Teoria da Dependência e na tese da deterioração dos termos de troca, o Terceiro Mundismo enquanto movimento político defendia que o subdesenvolvimento da periferia do sistema internacional ocorria em função do desenvolvimento de seu centro. Isto é, a existência de pobreza no mundo era devida não a teorias que responsabilizavam a topografia desfavorável, as culturas incompatíveis com a modernidade e o fato dos líderes nacionais não terem conhecimento técnico e cientifico para promover o desenvolvimento dos Estados como alertaram Acemoglu e Robinson (2012), mas sim à maneira na qual a riqueza era produzida, consequência de novos mecanismos de dependência que - uma vez acabada a dominação direta e a colonização tradicional - se constituíram em novas estruturas econômicas e sociais.

A característica mais marcante dessas novas estruturas se revelou no seio dos Estados subdesenvolvidos no que se convencionou chamar "sociedades duais", compostas de setores tradicionais e modernos culturalmente distintos e cujas existências não dependiam uma da outra. Se por um lado era possível afirmar que a existência de um setor moderno e de vanguarda permitia a agricultores de subsistência ganhar renda extra quando a ocasião permitisse (Berg, 1961) ${ }^{29}$; por outro, a crítica da Teoria da Dependência reclamava a tese da deterioração dos termos de troca e que matérias primas e força de

\footnotetext{
${ }^{29}$ Citado em Duffield (2001).
} 
trabalho dos países subdesenvolvidos eram adquiridas abaixo do preço verdadeiro por empresas do Norte (Frank, 1967) ${ }^{30}$.

Ao passo que a disputa ideológica se aprofundava e os movimentos de independência na Ásia e na África obtinham sucesso, o Terceiro Mundismo ganhava força enquanto movimento político internacional e enquanto alternativa à divisão Leste-Oeste do sistema internacional. Ainda que tal movimento prezasse por determinados valores políticos tais como a autodeterminação dos povos e a condenação firme a toda e qualquer forma de colonialismo como forma de construir a paz, ele não descartava o papel do desenvolvimento na garantia da mesma. Alguns indícios de que já havia forças apontando para a relação direta entre segurança e desenvolvimento podem ser extraídos da declaração final e de alguns discursos de chefes de Estado de Estados periféricos da I Conferência das Nações Unidas sobre Comércio e Desenvolvimento (I UNCTAD) em 1964.

Organizada no âmbito da Assembleia Geral da ONU, a UNCTAD fora convocada como forma de atender à demanda de países subdesenvolvidos que se queixavam que o Acordo Geral de Comércio e Tarifas (GATT) havia deixado de lado assuntos que lhes eram de sumo interesse. Mesmo que a convocação e o escopo da conferência tenham sido limitados estritamente a questões concernentes ao comércio internacional e ao desenvolvimento dos Estados, alguns chefes de Estado - principalmente de países do Terceiro Mundo - tomaram a oportunidade para expor ao mundo o que entendiam como sendo efeito que o desenvolvimento causaria em áreas outras que não as econômicas. A ideia deles era atrair a atenção dos Estados desenvolvidos para necessidade de auxiliar e cooperar com o desenvolvimento dos Estados subdesenvolvidos uma vez que o subdesenvolvimento poderia representar - de algum modo - uma ameaça à segurança internacional.

Dentre os chefes de Estado e governo que estiveram presentes e enviaram mensagens durante os trabalhos da conferência, destacam-se as falas de Ahmed Sékou Touré, primeiro presidente da Guiné e pai-fundador do país; de Sarvepalli Radhakrishnan, filósofo e estadista indiano; e de Josip Broz Tito, militar e presidente da Iugoslávia. Seus discursos, além de incisivos, foram ilustrativos no sentido de indicar que havia algum

\footnotetext{
${ }^{30}$ Idem.
} 
entendimento - ainda se falando de maneira ampla e geral - de que segurança e desenvolvimento estavam ligados.

Para o primeiro, a relação entre desenvolvimento enquanto satisfação individual de necessidades materiais e segurança era clara e direta uma vez que países haviam conquistado suas independências. Se por um lado o colonialismo deixava a cena paulatinamente; por outro, os Estados recém libertados passavam por momentos de (re)contrução das instituições estatais. Em suas palavras, "uma vez que as nações forem libertadas, a paz depende da possibilidade oferecida a cada povo para satisfazer todas as necessidades materiais e morais por meio do seu próprio trabalho". Além disso Touré utilizou-se de premissas liberais para lembrar a relação entre o comércio e a paz, tratando o primeiro como vetor do desenvolvimento: "transações comerciais são atualmente prejudiciais para a grande maioria dos povos do mundo e, consequentemente, para o fortalecimento dos fundamentos da paz mundial" (UNCTAD, 1964, p. 87).

O líder indiano, por sua vez, argumentou alertando para os interesses das Nações Unidas e apontou a pobreza como uma das ameaças à paz mundial. Para ele, este era o motivo pelo qual a ONU havia se interessado em promover o desenvolvimento econômico dos Estados. Na mesma linha, o líder iugoslavo não só afirmou que aquela conferência sobre comércio e desenvolvimento representava um interesse comum da comunidade internacional com relação ao desenvolvimento econômico e progresso social de todos os países do globo, como também representava uma contribuição importante para a preservação da paz mundial (UNCTAD, 1964).

A presença de líderes de países do Terceiro Mundo que entendiam haver algum tipo de vínculo entre desenvolvimento e segurança representou na verdade um argumento a mais na sua tentativa de criar mecanismos de comércio internacional capazes de neutralizar as perdas que julgavam ter tido com a liberalização comercial promovida pelo GATT e de se inserir na economia internacional. Da parte deles, a relação entre desenvolvimento e segurança parecia mais retórica do que uma real percepção dos acontecimentos. Na prática, o fato de muitos deles serem membros ou observadores do Movimento dos Não-Alinhados ou até mesmo orientados politicamente por Moscou fez com que a necessidade de (re)construção de suas economias não fosse necessária uma vez que já haviam sucumbido à ameaça que o Ocidente tanto temia ou não estavam inclinados a se alinhar com o bloco ocidental. 
Em períodos distintos, o Plano Marshall e a I UNCTAD apresentaram as primeiras contribuições às perspectivas que vinculam desenvolvimento e segurança internacional. Ainda que o primeiro tenha apontado a origem do subdesenvolvimento em questões domésticas enquanto o segundo apontava causas estruturais, ambos expuseram de forma clara que a fusão entre os dois conceitos atendia, cada qual à sua maneira, aos interesses daqueles que a promovia. O ponto crucial deste fenômeno e da convergência das agendas de segurança e de desenvolvimento se deu em meados dos anos 1970 quando, findado o período conhecido como Anos Dourados, o liberalismo econômico passou a orientar as economias capitalistas e a minar a coesão do bloco terceiro-mundista. A decadência da alternativa terceiro-mundista e a paulatina exclusão do Sul Global do sistema capitalista estão, portanto, diretamente ligada à problemática liberal que entende o subdesenvolvimento como algo perigoso (Duffield, 2001). ${ }^{31}$

Foi na década de 1970 que duas grandes mudanças tiveram lugar no sistema internacional. Primeiro, o sistema capitalista deixou de ser expansivo ou inclusivo para ser cada vez mais exclusivo e seletivo. A globalização, naquele momento, passava a consolidar diferentes sistemas econômicos regionais cujas ligações em redes produtivas, comerciais e de investimentos foram se tornando cada vez mais profundas dentro do Norte Global de modo a tornar o mundo cada vez mais assimetricamente interdependente. Além disso, a arquitetura da economia global se polarizou em um eixo que opunha áreas produtivas e com muitas informações e áreas pobres, desvalorizadas economicamente e socialmente excluídas (Castells, 1996). Na África, por exemplo, os anos 1970 se caracterizaram por uma queda significativa dos investimentos comerciais por parte dos países do centro (Duffield, 2001).

De todo modo, é importante pensar que essa exclusão não é literal. Ela também apresenta relações sociais subordinantes incorporadas em novas conexões, interação e relações de interdependência. Isto é, falar em exclusão do Sul a partir dos anos 1970 era falar em "novos tipos de restrição e formas emergentes e subordinadoras de integração Norte-Sul" (Duffield, 2001, p. 05). Neste sentido, a exclusão do Sul do sistema capitalista na verdade era ambivalente, uma vez que este continuou integrado ao norte por meio de

31 A expressão "Sul Global" é a correspondente atual à expressão "Terceiro Mundo". Ela tem sido cada vez mais utilizada na literatura pós-colonial para referir-se aos países em desenvolvimento e aos menos desenvolvidos. À diferença de sua versão mais antiga, essa expressão hoje é mais uma generalização acadêmica do que um bloco de solidariedade entre países (Braveboy-Wagner, 2003). Ela é, assim, uma oposição ao termo Norte Global. 
atividades transfronteiriças marginais, utilizando-se de formas novas e expansivas de redes local-global e de padrões inovadores de integração Norte-Sul, extralegais e informais.

Esta nova organização do sistema capitalista mudou de certa forma a geografia mundial: o Norte passava a ser entendido como uma geografia variável com bolsões de pobreza enquanto o Sul tinha sua arquitetura enrijecida e com pequenas seções ligadas às redes produtoras de altos valores. Tal reorganização do sistema capitalista deu maior espaço para atores não-estatais que, muitas vezes, agiam às margens da legalidade dos Estados onde estavam situados e dando assim origem à segunda mudança daquele contexto: a percepção de que a natureza da segurança havia mudado.

A segunda mudança do período apontava para o fato de que as guerras agora passavam a ser também intraestatais. Por mais que o ordenamento bipolar da Guerra Fria ainda perdurasse e que guerras entre Estados continuassem a ser o foco dos Estudos de segurança, os processos de independência da África Portuguesa, principalmente o caso de Moçambique e Angola que logo culminaram respectivamente em 15 e 27 anos de guerra civil, o início da guerra civil etíope, a primeira guerra civil eritreia e outros foram responsáveis pelo entendimento de que as ameaças à paz e à segurança internacionais poderiam vir também de dentro dos Estados, perspectiva esta que se consolidaria ainda mais na década seguinte.

A leitura dessas novas guerras logo ganhou divisões profundas nas análises. Por um lado, viu-se que esses novos conflitos tinham causas que levavam automaticamente a formas de colapso da sociedade e do Estado e eram entendidas pelos doadores internacionais como regressões sociais, isentas de causas políticas maiores. Por outro, eles foram entendidos também como algo que acontecia em função do reordenamento do Estado que resultavam na criação de novos tipos de legitimidade e autoridade (Duffield, 2001). É desta leitura, por exemplo, que Krasner (1999), Herbst (2004) e outros concluíram anos depois os efeitos benéficos da falência dos Estados frágeis e fracos.

Independentemente da leitura feita, era fato que o alto e crescente número de refugiados dos anos 1970 e 1980 era indício de que algo não ia bem em vários Estados do mundo, uma vez que aqueles fugiam precisamente de conflitos domésticos. Foi neste contexto que, logo no início dos anos 1980, discutiu-se em um Comitê Político Especial da ONU a causa do fluxo dos refugiados. Não tardou para que o comitê se visse dividido 
em torno de duas visões sobre as primeiras causas da origem dos fluxos de refugiados. Por um lado, países ocidentais e seus aliados anticomunistas chamavam a atenção para os abusos e as violações dos Direitos Humanos ocorridas internamente. Por outro, países do Terceiro Mundo e os socialistas apontavam seus dedos para o colonialismo, a desigualdade global, os crescentes problemas na balança de pagamentos e para a deterioração dos termos de troca. Ou seja, o debate logo se dividiu entre aqueles que apontavam para as causas domésticas dos fluxos de refugiados e aqueles que acusavam questões externas para justificar a instabilidade geradora desta migração forçada (Suhrke, 1994). É importante notar que os principais países de origem dos refugiados se encontravam neste segundo grupo.

A divisão dentro do comitê foi tão profunda que dois relatórios foram produzidos. O primeiro, em 1981, apontava para as causas internas aos Estados como fator preponderante na produção da migração forçada. $\mathrm{O}$ segundo, que apontava para causas externas, foi concluído e publicado apenas quatro anos depois. Não se pode afirmar ao certo se o que outorgou maior importância ao primeiro foi o fato de ter sido concluído antes ou se foi o novo momento da política internacional combinado com as forças políticas daqueles que o produziram. O que intriga é que ambos os relatórios apontavam - cada qual à sua maneira - para questões ligadas ao subdesenvolvimento como a causa primeira do fluxo de refugiados.

O Relatório do Grupo de Peritos Governamentais em Cooperação Internacional para Impedir Novos Fluxos de Refugiados ${ }^{32}$, publicado em 13 de maio de 1986, era majoritariamente composto por países em desenvolvimento e destacava causas externas aos Estados como as "estruturas globais de desigualdade" como responsáveis pelo fluxo de refugiados nos países em desenvolvimento. Específica e minuciosamente, o relatório apontava dois tipos de circunstâncias causadoras: aquelas causadas pelo homem e aquelas causadas pela natureza. As primeiras, no caso, foram divididas entre causas de natureza política e causas de natureza econômica. No primeiro caso, o relatório acusava o colonialismo, os regimes de segregação racial e a dominação e intervenção estrangeira como origem do fluxo de refugiados. No segundo, eram os "problemas estruturais do desenvolvimento" que mereciam destaque: "o prolongamento de um estado de subdesenvolvimento herdado do colonialismo e agravado por um ambiente econômico

\footnotetext{
${ }^{32} \mathrm{~A} / 41 / 324$ de 13 de maio de 1986.
} 
difícil", caracterizado ainda pela crítica terceiro-mundista que foi tão forte nos anos 1960 (ONU, 1986, p. 11).

Tal relatório, contudo, já fora produzido em um momento de enfraquecimento tanto de seu conteúdo quanto do bloco que o produzira. Além de o fato de o Terceiro Mundo estar perdendo a coerência naquele momento (o que muito contribuiu para a demora da publicação do documento), a divulgação do relatório concorrente em 1981 serviu como uma vitória de correntes neoliberais sobre os adeptos da Teoria da Dependência e do Socialismo Internacional. Conhecido como Relatório Aga Khan, o Estudo sobre Direitos Humanos e Êxodos Massivos ${ }^{33}$ deu mais peso para as questões internas aos Estados, ainda que afirmasse que uma leitura adequada devesse levar em conta tanto as condições nacionais quanto as estruturas econômicas globais (Suhrke, 1994). Apesar disso, o relatório apontou apenas para as questões internas, focando para dois tipos de conflitos: aqueles relacionados à formação dos Estados e aqueles relacionados à ordem social dos países de origem dos refugiados. Enquanto neste o foco foi posicionado sobre problemas socioeconômicos, naquele o centro das atenções residia em problemas de natureza política.

Dentre os problemas socioeconômicos destacados, o relatório apontava para o fato de que, nos países de origem, o alto crescimento populacional, o desemprego massivo, o êxodo rural e a desertificação contribuíam para a "falta de oportunidades econômicas para muitas pessoas" que desencadeava em um corolário inevitável: "ruptura política que desencadeia na eliminação de seções da população". De acordo com o relatório, inquietação e instabilidade política dentro dos países com tais condições socioeconômicas são consequências inevitáveis uma vez que a migração transnacional, que serviria como "válvula de escape", não é facilitada na maioria dos casos. O documento ainda ressaltou que tais "fatores de impulso" 34 podiam ainda agravar-se dado a circunstâncias e opções políticas e econômicas desfavoráveis ao desenvolvimento, tais como a alta proporção de orçamentos anuais dedicados para equipar as Forças Armadas; a inadequação dos serviços públicos; e a perda de mercados internacionais para exportações (ONU, 1981, p. $37)$.

\footnotetext{
${ }^{33}$ E/CN.4/1503, 31 de dezembro de 1981.

${ }^{34}$ NT: "push-factors".
} 
Por outro lado, o relatório compreendeu também os problemas políticos decorrentes da formação dos Estados que haviam se tornado independentes em um passado próximo. Neste sentido, identificou-se que a tentativa de construir uma identidade nacional acompanhando a transição de uma sociedade tribal e feudal para um Estado-Nação moderno costumava desencadear em conflitos étnicos, repressão e perseguição a minorias (Suhrke, 1994, p. 15), o que se agravava com a pronta disponibilidade de armas para os combatentes e com o fato de muitos destes só terem atingido mínima coesão nacional por meio de governos autoritários e unipartidários. Ademais, os legados do colonialismo em boa parte do mundo em desenvolvimento especialmente na África - foram destacados no estudo que reconhecia que as fronteiras artificiais, as economias desequilibradas e os regimes de minoria branca feriam os direitos humanos (ONU, 1981) e, desta forma, levavam a prolongadas lutas de libertação nacional que exacerbaram a destruição e a tensão dentro dos Estados.

O estudo concluiu, então, que a combinação de todos os fatores de impulso - tanto de natureza política quanto de natureza socioeconômica - levava à "inabilidade de muitos governos em criarem condições nas quais a população como um todo pode esperar gozar - além dos direitos civis e políticos - dos direitos econômicos, sociais e culturais estabelecidos na Declaração dos Direitos Humanos" (ONU, 1981, p. 38) e esboçou algumas sugestões de política a serem tomadas tendo em vista a solução do problema, tais como a democracia e a institucionalização da ajuda para os países em desenvolvimento.

Tal relatório foi uma das primeiras claras exposições vinda de uma organização internacional sobre a visão de que "conflito é em última análise um reflexo do mal-estar do subdesenvolvimento" (Duffield, 2001, p. 27). Até então, as tentativas de vincular segurança e desenvolvimento partia de iniciativas de países específicos seja por discurso, legislação ou ato de política externa com vistas a atender a certos interesses nacionais e como tais iniciativas adentraram e permearam debates em organizações internacionais, além do Plano Marshall e da I UNCTAD. O que mudou nesta tentativa de vínculo e conferiu força ao discurso foi o momento de ascensão do Liberalismo no momento de declínio da Guerra Fria. Além disso, ao atentar para problemas políticos e econômicos internos aos Estados, as principais economias mundiais não só se inibiram da responsabilidade que lhes era imputada pelos defensores da Teoria da Dependência e do 
Socialismo Internacional como também puderam aproveitar uma nova oportunidade para satisfazer a seus interesses.

Ainda que durante os anos 1970 o debate por uma Nova Ordem Econômica Internacional (NOEI) fez com que instituições e governos doadores tivessem que ao menos reconhecer a pressão exercida pelo Terceiro Mundo com a Convenção de Lomé35 de 1975, a decadente coesão do bloco periférico abriu espaço para que a partir dos anos 1980 muitas instituições e governos doadores assim como organizações internacionais passaram a criar e incorporar a ideia de que o subdesenvolvimento é perigoso para a paz e segurança internacionais. Tal ideia transferia para os países do Sul e seus atores a responsabilidade de resolver problemas que supostamente seriam apenas seus. Ao que se redefiniu o subdesenvolvimento como algo perigoso a partir de uma posição de dominação, o discurso liberal suprimiu as ideias terceiro-mundistas que atentavam para a existência das desigualdades entre e dentro dos países do mundo e para o fato de que a riqueza gerada no mundo estava diretamente ligada com a pobreza gerada à mesma ou em maior proporção. O entendimento de que o subdesenvolvimento é perigoso "não é um ato imparcial de análise social; é uma construção histórica e política" e bastante cara à guinada neoliberal na política e na economia globais a partir da década de 1980 (Duffield, 2001, p. 28).

Foi a partir dessa mudança e da nova característica da política internacional que se passou a discutir a existência de uma "paz liberal" ou de novas formas de imperialismo. Ainda em 1981 - mesmo ano de publicação do Relatório Aga Khan - o presidente americano Ronald Reagan se pronunciara em discurso na Cúpula de Cancún ${ }^{36}$ e indicou uma guinada internacional para as estratégias neoliberais de desenvolvimento, chamando a atenção para os ajustes estruturais e as condicionalidades que passariam a ser exigidas e impostas dos países em desenvolvimento com vistas a criar um bom ambiente doméstico nos países que seriam financiados para encorajar investimentos externos (Duffield, 2001).

\footnotetext{
${ }^{35}$ A Conferência de Lomé I foi um acordo comercial entre a Comunidade Econômica Europeia e os países da ACP (África, Caribe e Pacífico). Contou com a participação de 46 Estados e definiu uma coordenação comercial entre eles de modo a garantir o aceso dos mercados comunitários aos produtos dos países da ACP e também a garantir a estabilidade das receitas provenientes das exportações de produtos-chave da ACP. Estabeleceu também instituições encarregadas de gerir seus acordos.

${ }^{36}$ A Conferência Norte-Sul de Cancún para a Cooperação Internacional e o Desenvolvimento reuniu 22 países em outubro de 1981 e teve como principal alvo de discussão as políticas que poderiam ser adotadas para retirar os países da América Latina do ciclo vicioso do endividamento externo.
} 
Tal cúpula - mesmo não tendo discutido questões de segurança internacional tornou-se símbolo desta guinada ao neoliberalismo e da responsabilização individual dos países. A abordagem que Reagan deu à questão Norte-Sul em uma reunião conjunta do FMI com o Banco Mundial antes da cúpula deixava clara sua preferência por programas de assistência bi e multilaterais e que "a menos que uma nação ponha suas questões financeiras e econômicas em ordem, nenhuma quantidade de ajuda vai produzir progresso". Além disso, o próprio fato de sua visão não ter encontrando resistência por parte do Terceiro Mundo e de países industrializados como a França do presidente socialista François Mitterrand e ter assim prevalecido indicava cada vez mais que a origem dos problemas bem como suas soluções deveriam ser encontradas dentro dos Estados, e não nas estruturas política e econômica do sistema internacional (The South African Institute of International Affairs, 1981, p. 2).

Dali em diante, a leitura do desenvolvimento como função da relação estrutural entre ricos e pobres não estaria mais presente nas políticas e discursos assim como fortaleceu a ideia de que o desenvolvimento "tornou-se um processo de autoadministração dentro de um ambiente de mercado liberal”. Foi então neste sentido que as questões desenvolvimentistas e de segurança foram focadas diretamente nos assuntos internos aos Estados. A diminuição do escopo dos Estados subdesenvolvidos, e agora endividados, expandiu suas esferas econômicas sobre as políticas uma vez que era necessário atender a uma série de condicionalidades: o desenvolvimento sob o viés neoliberal agora preponderante estava diretamente ligado não apenas à liberalização econômica, mas também à criação e existência de regimes e instituições democráticas (Duffield, 2001, p. 30).

Foi neste sentido, então, que o fim da Guerra Fria acabou na verdade aprofundando e fortalecendo as características do sistema neoliberal emergente daquele momento. É neste período de decadência da lógica da Guerra Fria e consequentemente do afastamento progressivo das superpotências em relação aos países periféricos que a lógica de que a causa dos conflitos, do subdesenvolvimento e - mantendo a discussão que gerou o relatório Aga Khan - da origem dos refugiados residiam no plano interno aos Estados e, assim, deveriam ser resolvidos através de soluções que indicassem uma melhor organização interna dos Estados. Quando os Estado não eram capaz de fazê-lo, outros atores não-estatais (principalmente) se disponibilizavam para auxiliá-los em dita tarefa. 
Assim, começava a entrar em cena nesse período de transição para a ordem internacional do pós-Guerra Fria um sistema no qual a cooperação determinaria os rumos da assistência para o desenvolvimento e o acesso para as variadas redes que compõem a governança global ao passo que a não cooperação possibilita o isolamento do Estado e uma série de condicionalidades a mais que impediriam a ajuda. É importante lembrar, contudo, que a dita cooperação deveria sempre permitir a atuação de atores não-estatais bem como empresas multinacionais e agências e organizações internacionais que, pelo menos teoricamente, ajudariam a promover o desenvolvimento dos Estados e a melhorar as condições de vida de seus cidadãos. Esse sistema, conhecido como a paz liberal, é uma relação não territorial, mutável e enredada da governança global, sem o controle direto do território de um Estado. A paz liberal, então, “aspira a garantir a estabilidade dentro dos complexos políticos que encontra em suas fronteiras movediças por meio dos princípios de desenvolvimento, parceria e auto-gestão" (Duffield, 2001, p. 34).

Durante boa parte da Guerra Fria, as condições políticas do sistema internacional de certa forma impediram que assuntos de segurança nacional e internacional fossem incorporadas pelo discurso do desenvolvimento. Ainda que, como demonstrado, a Doutrina Truman e os discursos durante a I UNCTAD o tenham tentado, é apenas durante os anos 1980 que há uma aproximação entre as duas esferas e um entendimento da comunidade internacional que se pode chamar de significativo. Este período de aproximação das duas agendas e de incorporação da segurança no discurso do desenvolvimento coincidiu com o advento do neoliberalismo econômico e com o fenômeno de internacionalização dos Estados, isto é, com o processo pelo qual as instituições políticas e as práticas nacionais se ajustaram às estruturas evolutivas e às dinâmicas da economia mundial de produção capitalista (Cox, 1987).

As novas condições econômicas e políticas no sistema internacional que emergiram com o declínio da Guerra Fria permitiram, então, que o discurso sobre o desenvolvimento voltasse a incorporar preocupações com a segurança nacional e internacional. A forma com que países e líderes do Terceiro Mundo tentaram unir tais discursos e agendas foram suprimidas do debate e da política internacional que guardou espaço apenas para a leitura advinda dos países centrais do sistema internacional, resgatando o raciocínio presente na Doutrina Truman e no plano Marshall e coerentemente reproduzindo-o no relatório Aga Khan. 
A fusão dos conceitos de desenvolvimento e segurança mostrou-se no começo dos anos 1990, contudo, muito mais abrangente e foi aprofundada e reverberada por acadêmicos, instituições militares, ONGs, empresas privadas de segurança etc. e entrou assim nas perspectivas mainstream das Relações Internacionais. Em um contexto no qual acadêmicos e policymakers se mostravam preocupados com os desdobramentos das guerras na Somália e na antiga Iugoslávia, a crescente participação e interação entre esses agentes institucionalizou o entendimento de que as guerras daquele período não passavam de um "mal-estar desenvolvimentista da pobreza, da disputa por recursos e das instituições fracas e predatórias" e, portanto, refletia a agenda da Paz Liberal que tratava o subdesenvolvimento como perigoso (Duffield, 2001, p. 15).

Naquele contexto, a questão das capacidades Estatais começou a ser incorporada ao debate. A introdução do conceito de "quase-estados" e de "soberania negativa" por Robert Jackson (1990), isto é, de Estados que apenas existiam graças ao reconhecimento formal de suas soberanias externas uma vez que não tinham capacidades de gozar da soberania empírica no plano doméstico, é um exemplo de como o desenvolvimento e a segurança passaram a ser entendidos como problemas domésticos que potencial e eventualmente poderiam perpassar as fronteiras de um Estado tornando uma crise regional. A existência de Estados apenas como soberania negativa e suas consequências foram notadas pela comunidade internacional e expostas no relatório Uma Agenda para a Paz, do então Secretário Geral da ONU Boutros Boutros-Ghali.

No relatório redigido a pedido do Conselho de Segurança da ONU, Boutros-Ghali destacou que não apenas conflitos militares entre os Estados ameaçavam a paz e a segurança internacionais naquele momento, mas também pobreza, fome, doenças, desigualdades, opressão etc. (ONU, 1992). Ainda que tal relatório tenha entrado para a história pela sistematização de formas de prevenção e de soluções de conflitos, ele foi o primeiro documento oficial da ONU a alertar para o fato de que as ameaças à paz poderiam vir de dentro dos Estados. Foi neste sentido que, no ano seguinte, o PNUD lançou o programa Linking Rehabilitation to Development, já apontando para a tendência de vincular desenvolvimento com a solução de conflitos. Foi a partir das práticas de tal programa que uma das primeiras definições de Estado falido surgiu na academia, classificando-o como uma situação onde as estruturas governamentais estão sobrecarregadas pelas circunstâncias e que não são capazes, portanto, de prover segurança física e condições mínimas de bem-estar para seus cidadãos (Helman \& Ratner, 1993). 
Foi finalmente em 1994 que a mudança e ampliação do conceito de segurança, vinculando-o ao desenvolvimento e a outras questões, ganharam sua força máxima enquanto discurso político. Por um lado, a criação do State Failure Task force atendendo ao pedido do então vice-presidente americano Al Gore e que reunia renomados cientistas sociais e peritos em coleta de dados e métodos estatísticos - trouxe uma visão extremamente multifacetada sobre a segurança e a sorte dos Estados, trabalhando com mais de mil variáveis (King \& Zeng, 2001). A maior potência militar, política e econômica da época endossara a fusão das agendas de desenvolvimento e segurança, considerando-a na análise das causas e consequências da falência dos Estados. Por outro lado, a divulgação do Human Development Report de 1994 pelo PNUD tratou de normatizar, no seio das Nações Unidas, uma visão bem menos ambiciosa, mas que ainda assim indicava para uma fusão entre as duas temáticas. Sua perspectiva agora era de que havia uma necessidade de mudar o eixo sobre o qual se baseava o conceito de segurança, saindo de uma lógica exclusivamente preocupada com a segurança territorial e que identificava nos armamentos a única via para garanti-la para uma lógica que dava muito mais ênfase na segurança das pessoas através do desenvolvimento humano sustentável (United Nations Development Programme, 1994).

Foi deste documento que ocorreu a principal força para a construção do vínculo entre os conceitos de segurança e desenvolvimento. Tal entendimento baseou-se em três causas essenciais que são o cumprimento por parte do Estado e da Comunidade Internacional de condições básicas de sobrevivência para a população (freedom from want); a prevenção estrutural da insegurança, tendo como referência uma ideia multidimensional da paz; e o imperativo de proteção em caso de violações dos Direitos Humanos (freedom from fear) (Pureza, 2009). Destas, a primeira é mais ligada à questão do desenvolvimento e é também aquela que permite o diálogo da segurança humana com a literatura de Estados falidos. A exigência do cumprimento de condições elementares para a sobrevivência das pessoas e para a administração das relações entre governos e pessoas trouxe a questão de que a periferia do Sistema Internacional - mais pobre e onde se concentra a maior parte dos Estados falidos - apresentaria uma falha na modernidade institucional e jurídica e, por isso, seus Estados seriam incapazes de fornecer bens públicos tais como o desenvolvimento, a boa governança e a segurança para suas populações. 
Ainda que preservassem a existência de um vínculo causal entre as esferas de segurança e desenvolvimento, os primeiros anos da década de 1990 apresentaram uma importante mudança no modo em que tais conceitos estavam ligados. Até os anos 1980 a questão da segurança havia sido incorporada pelo discurso do desenvolvimento tratando a primeira como um fim e o segundo como um meio passando por uma sensível alteração na década seguinte. A suposta relação direta entre desenvolvimento e segurança passou a ser incorporada, entre outras, à questão da fragilidade dos Estados e como esta poderia ser uma ameaça à segurança internacional. Ao passo que policymakers debruçavam-se sobre o assunto objetivando uma compreensão mais ampla acerca do tema, isto é, que cada vez mais vinculasse as esferas de desenvolvimento e segurança, a academia prontamente se dispunha a sistematizar e acompanhar o progresso de tal ferramenta conceitual que já começava a ganhar a alcunha de Estado falido. Não à toa, os primeiros índices que visavam a medir a falência dos Estados já apontavam como os mais problemáticos justamente aqueles em que a população se encontrava paupérrima e com a ocorrência de conflitos internos, com certa predileção por este com relação àquele.

Com a guinada neoliberal na política internacional, que passou a entender que a solução de problemas domésticos deveria ser de responsabilidade primária de cada Estado, e com o advento da preocupação com as novas guerras e com os Estados falidos, a segurança passou a ser vista como um meio para o desenvolvimento e não mais o contrário. Se até os anos 1970 havia algum consenso entre os países desenvolvidos de que o desenvolvimento era a principal forma de evitar ameaças à segurança internacional principalmente por evitar que a periferia sucumbisse ao comunismo soviético, a guinada neoliberal dos anos 1980 e sua institucionalização na primeira metade da década de 1990 inverteu a situação: agora, era preciso garantir a segurança interna e a qualidade das instituições domésticas para que o desenvolvimento encontrasse solo fértil para sua instalação, permanência e reprodução.

Foi William Zartman (1995) quem começou a trabalhar a complexidade e o amplo espectro de definições e variáveis sobre a falência estatal nesse sentido. Apenas a partir daí que os conceitos de "Estado falido" e de "Estado frágil" começaram a dialogar e se mesclar, sendo o primeiro termo preferido geralmente por peritos e estudiosos do desenvolvimento e o segundo por diplomatas e peritos em segurança. Os próprios discursos proferidos por Boutros-Ghali e a então secretária de Estado americano Madeleine Albright na época ilustraram bem a diferenciação entre falência e fragilidade 
e a cada vez maior aproximação entre segurança e desenvolvimento (Grimm, LemayHébert, \& Nay, 2014).

Não foi apenas nos Estados Unidos, contudo, que os governos criaram órgãos para discutir, estudar e compreender as questões dos Estados falidos e da fusão entre segurança e desenvolvimento. A criação do Department for International Development no Reino Unido em 1997 mostrou que havia sim outros países consternados com a temática e a aparente nova forma de ameaças à segurança. Ao pôr ênfase na redução da pobreza, na segurança humana e no reconhecimento do papel do Estado nos países em desenvolvimento, os britânicos assim alinharam-se com as preocupações americanas e da ONU naquele fim de década. Além deles, também o governo da Suécia passou a entender de modo semelhante naquele momento. O primeiro começou a entender que "ameaças à nossa própria segurança hoje são associadas, entre outras coisas, com as tendências da população global, combinada com desenvolvimento e justiça econômica lentos" (MRE Suécia, 1997) ${ }^{37}$ como também que "enquanto o foco costumava estar nas ameaças à segurança militar, reconheceu-se gradualmente que a segurança internacional e a estabilidade regional deveria também estar baseada no respeito aos direitos humanos e à governança democrática" e que "a segurança humana é uma pré-condição para a estabilidade social que é crucial para a paz e segurança regional e internacional" (MRE Suécia, 2000, p. 12).

Foi seguindo estas linhas de pensamento que, no âmbito acadêmico, o vínculo entre segurança e desenvolvimento ficou ainda mais claro e ganhou bastante espaço no debate quando já parecia quase consensual que a segurança tinha como cerne a sobrevivência e, portanto, deveria incluir outras questões além das militares (Buzan, Waever, \& Wilde, 1998). Nos anos 1990, o binômio segurança-desenvolvimento já aparecia atrelado à discussão sobre Estados falidos, porém só passou a habitar o mainstream das Relações Internacionais apenas após os atentados terroristas de 11 de setembro de 2001, quando a discussão sobre os Estados falidos e frágeis voltou com força após breve interregno focando majoritariamente a paz liberal. Neste novo contexto, os chamados Estados frágeis ou falidos passaram a dominar o debate sobre segurança internacional nos principais centros acadêmicos, diplomáticos e militares americanos e, por conseguinte, acabou reverberando para a agenda de estudos das RI no resto do mundo.

\footnotetext{
${ }^{37}$ Citado em Duffield (2001, p. 36).
} 
Ainda que os EUA considerassem Estados frágeis e falidos em seus discursos, parecia haver um consenso em boa parte dos analistas de que a melhor forma de evitar um novo Afeganistão (que dava porto seguro à Al Qaeda) era o de capacitação de governos nacionais no Sul Global, almejando que estes passassem a controlar seus territórios e fossem capazes de prover serviços essenciais para seus cidadãos (Grimm, Lemay-Hébert, \& Nay, 2014).

Tal perspectiva ficou bastante evidente no próprio discurso do então Secretário Geral da ONU Kofi Annan na cerimônia em que recebeu o Prêmio Nobel da Paz de 2001, quando afirmou que países que violavam a nomocracia e direitos individuais dos cidadãos eram uma ameaça para todo o mundo (Annan, 2001). Além disso, o lançamento da iniciativa Low-Income Countries Under Stress (LICUS) pelo Banco Mundial já demonstrava a preocupação com os países receptores de ajuda internacional que vinham sofrendo com os efeitos da guerra, violência e de rupturas políticas. Tal iniciativa gerou dentro daquela instituição duas novas divisões dedicadas, cada uma, a Estados frágeis e à prevenção de conflitos e reconstrução. Claramente, tanto a ONU quanto o Banco Mundial deslocavam suas preocupações da eficiência da ajuda para uma ênfase maior na construção da paz e dos Estados. A questão da falência e da fragilidade se tornava tão próxima da segurança internacional naquele momento que os EUA chegaram a afirmar que eram mais ameaçados por Estados falidos ou em vias de falir do que por Estados expansionistas e conquistadores (National Security Council, 2002) e a UE classificou-os entre as cinco principais ameaças à sua segurança (União Europeia, 2003).

Uma tímida dissociação entre os entendimentos da academia e as instituições internacionais se notou de 2003 em diante. Ao passo que a primeira continuou apostando fortemente no vínculo entre segurança e desenvolvimento e na paz liberal, dando ênfase à segurança internacional, a segunda passou a focar mais na questão desenvolvimentista dos Estados frágeis, mas ainda motivados pela estreita correlação entre as duas esferas. $\mathrm{Na}$ primeira, havia vozes que defendessem os incentivos materiais para financiar a reforma das instituições estatais em Estados não-liberais, enquanto na segunda, foi a reforma das instituições que passou a se condição para o recebimento de tais incentivos. Foi nesse ano, por exemplo, que o Human Development Report do PNUD elencou 59 países entre as suas maiores prioridades e classificou-os como Estados que combinam baixo desenvolvimento humano e fraco desempenho (United Nations Development Programme, 2003) e que Rotberg (2004) organizou um estudo bastante aprofundado 
sobre as causas e consequências da falência dos Estados. Desde então, organizações e mecanismos internacionais ${ }^{38}$ como a OCDE e a USAID desenharam políticas e compromissos específicos para os Estados frágeis.

Essas organizações faziam, sobretudo, recomendações sobre questões desenvolvimentistas motivadas pela preocupação com a segurança internacional. $\mathrm{O}$ relatório do então Secretário Geral da ONU Kofi Annan intitulado In Larger Freedom: towards development, security and human rights for all tratou de reforçar o vínculo entre a paz liberal e a questão da falência e da fragilidade dos Estados ao discorrer sobre as liberdades de carência, de medo e para viver dignamente. Este acabou se tornando a pedra basilar do entendimento das ameaças à segurança internacional no século XXI, inclusive para os questionamentos da OCDE (2011) sobre como lidar com a questão no início da segunda década do século XXI.

\subsection{Motivos para questionar}

Essa percepção que se consolidou a partir da segunda metade da última década do século XX não é apenas uma questão acadêmica: ela tem implicações políticas profundas que variam desde a percepção de uma ameaça até as políticas feitas para estabilizar e/ou fazer um Estado atingir metas de desenvolvimento. Desde o 11 de setembro de 2001, a percepção dos EUA sobre suas ameaças mudou levando em consideração esta perspectiva. Para o contexto que se inaugurava, as principais ameaças à segurança americana não partiam mais de um Estado forte e armado, mas sim de Estados fracos e frágeis nos quais grupos terroristas poderiam se esconder e operar suas atividades. Isto é, os Estados falidos não poderiam ser mais visto apenas sob o prisma dos Direitos Humanos (Nasser, 2009). A falta de autoridade dos Estados e a precariedade das situações social e econômica em que muitos se encontravam seriam o terreno propício para uma disputa de corações e mentes na qual grupos terroristas cooptariam e arrolariam indivíduos para lutar por suas causas. Deste modo, Estados como a Somália poderiam se converter em novos "afeganistões", servindo de porto seguro para grupos terroristas.

À exceção de autores críticos e pós-coloniais tais como Grovogui (2001), a literatura sobre Estados frágeis e falidos divide-se - de modo superficial - entre aqueles que os enxergam como uma ameaça aos Estados mais poderosos e consolidados (Rotberg,

\footnotetext{
${ }^{38}$ Millennium Challenge Corporation, da USAID de 2004 e a Declaração de Paris sobre a Efetividade da Ajuda, da OCDE de 2005
} 
2005; Le Sage, 2007) e aqueles que os veem como terreno propício para a disputa entre as grandes potências (Nasser, 2009). De qualquer modo, todos parecem concordar que a questão da falência de Estado está diretamente vinculada à autoridade estatal, à legitimidade de suas instituições e/ou governo e ao seu desenvolvimento humano e social. Tal literatura e conceito derivam, portanto, da própria discussão sobre a conceituação de segurança humana e do vínculo causal entre segurança e desenvolvimento. Mesmo que a literatura dê destaque à presença de conflitos nos Estados falidos que são também os mais pobres e subdesenvolvidos, é preciso explorar com profundidade a presença de correlações espúrias entre alguns dos indicadores que compõem boa parte dos índices de falência de Estado e a ocorrência de conflitos e até mesmo a falta de correlação entre eles, principalmente com a questão do desenvolvimento.

À primeira vista, os dados recolhidos no Worldwide Governance Indicators (2014) e na Fondation pour les Études et Recherces sur le Développement International (2015) parecem apoiar a teoria da fusão entre segurança e desenvolvimento na África Subsaariana. Analisando os 968 casos do universo estudado ${ }^{39}$, alguns dados iniciais saltam aos olhos neste sentido. Em primeiro lugar, não houve nenhum caso de conflito intraestatal nos Estados que estavam nas categorias A ou B - as mais altas da amostra e países que progrediram da categoria C para a B (Botsuana, Cabo Verde, Guiné Equatorial e Maurício) não foram palco de conflitos desta natureza em todo o período estudado. Além disso, a África do Sul e o Gabão estiveram na categoria B em todo o intervalo, enquanto Seicheles foi o único país que atingiu a categoria $\mathrm{A}$, embora tenha descendido para a categoria B dois anos depois. Ademais, nenhum país que estava ou atingiu a categoria B foi rebaixado no período analisado. Destarte, tais dados parecem apoiar a ideia de que o desenvolvimento e a segurança estão intimamente relacionados e são interdependentes. Na verdade, eles sugerem que a categoria B pode ser uma linha de graduação que divide os países suscetíveis a conflitos e os países seguros assim como uma linha separando os países com dificuldades no desenvolvimento e os países com desenvolvimento estável e sustentável.

Uma análise mais aprofundada, contudo, mostra que houve graduações em países que eram palco de conflitos intraestatais. Burundi, Chade, Libéria, Ruanda e Uganda foram capazes de melhorar sensivelmente seus níveis de desenvolvimento de modo a

\footnotetext{
${ }^{39}$ Dados anuais de 44 países entre 1990 e 2011.
} 
mudar da categoria $\mathrm{D}$ - a mais baixa de todas - para a $\mathrm{C}$ durante seus conflitos internos. Ainda que seja verdade que o Chade logo voltou para a categoria D e que a Libéria apenas avançou no último ano de seu conflito, os demais países são casos importantes que contradizem (mas não necessariamente invalidam) a tese da fusão entre desenvolvimento e segurança.

De fato, há muitas evidências que parecem apoiar e, paradoxalmente, contradizer tal perspectiva. Por um lado, quanto mais baixa a categoria do desenvolvimento, maior a incidência de conflitos intraestatais: enquanto não houve casos de conflitos nos Estados classificados como A ou B, $12 \%$ dos casos em C e 38,4\% dos casos em D sim apresentaram a incidência de conflitos internos. O que é digno de atenção, por outro lado, é que os casos na categoria D representam apenas 11,6\% de todos os 968 casos. Se houvesse uma relação entre a categoria de desenvolvimento e a ocorrência de conflitos intraestatais, estes deveriam acontecer dentro de uma categoria na mesma proporção que a categoria aparece na amostra. No entanto, a ocorrência de conflitos em Estados na mais baixa categoria de desenvolvimento não segue este critério. Assim sendo, é possível rejeitar a relação entre segurança e desenvolvimento na África Subsaariana. ${ }^{40}$

As origens das guerras intraestatais e da instabilidade podem ser encontradas em variáveis outras além do desenvolvimento. Quando Kapuściński (2005) entrevistou exfuncionários do palácio imperial etíope, ele coletou um depoimento o qual afirmava que a fome era indispensável para "domar e subjugar a fera que o homem é". Por mais cruel que possa parecer, os dados da amostra sugerem que tal pensamento é verdadeiro para a África Subsaariana. Não só os conflitos ocorreram de modo mais recorrente nos casos da categoria $C(67,7 \%$ de todos os casos com conflitos), não se pode rejeitar também a relação entre ela e uma realidade propensa a conflitos dentro de um determinado Estado naquela região. ${ }^{41}$

Como será demonstrado ao longo deste e dos próximos capítulos, a chave para entender a origem dos conflitos intraestatais e a falência dos Estados na África Subsaariana parece não estar, portanto, no subdesenvolvimento de seus Estados. Isto não é boa notícia para indivíduos preocupados e comprometidos com a promoção do desenvolvimento no mundo. A interpretação de desenvolvimento que se tornou

\footnotetext{
${ }^{40} \mathrm{p}$-value $=8.472 \mathrm{e}-15$ para uma confiança de 0.99

${ }^{41} \mathrm{p}$-value $=0.02319$ para confiança 0,99 .
} 
hegemônica abrangendo não apenas a renda per capita, mas também a vulnerabilidade econômica dos países e os recursos humanos que eles têm foi a mais utilizada pela ONU para afirmar sua relação com a ocorrência de conflitos armados. Este talvez seja um dos principais motivos para afirmar, contudo, que o subdesenvolvimento - cujo conteúdo fora securitizado principalmente a partir dos anos 1990 - não está relacionado à ocorrência de conflitos na África Subsaariana. ${ }^{42} \mathrm{Se}$, à primeira vista, os dados pareciam corroborar a ideia de que desenvolvimento e segurança caminham juntos e estão intimamente ligados, uma análise mais aprofundada sobre eles demonstrou que pelo menos na África Subsaariana a suposta relação causal entre desenvolvimento e segurança não deve ser levada como dogma. A fusão entre estas duas áreas é problemática principalmente por três motivos.

Primeiro, a segurança e o desenvolvimento são conceitos essencialmente controversos. Eles delimitam a área de interesse do pesquisador mais do que representam uma condição particular de como as coisas acontecem. Isso geralmente acontece uma vez que são definidos em termos gerais e negativamente, isto é, são definidos como o alívio de ameaças às necessidades primeiras do ser humano. Tal fato se deve às dificuldades nas definições positivas que esbarram em controvérsias acadêmicas e que acabam refletindo a realidade de povos e locais em determinados tempo na história (Spear \& Williams, 2012). Tal crítica também é válida para o conceito de Estado, principalmente em locais não-ocidentais, para os quais uma vasta literatura pós-colonial questionou e rechaçou suas premissas. Ainda que relativize os conceitos, destacando-os de seus vínculos espaçotemporais de modo a torná-los operatórios como meros modelos analíticos ${ }^{43}$, é preciso levar ter em mente que tal empresa dificulta e fragiliza os esforços de análise científica sobre tais objetos. Em outras palavras, a conceituação de segurança, desenvolvimento e Estado acabam sendo elaboradas muito com base no know it when you see it. Para não cometer o mesmo erro, este trabalho apresentará detalhadamente seu entendimento sobre tais conceitos.

\footnotetext{
${ }^{42} \mathrm{O}$ processo de securitização assume que um determinado assunto passou a ser entendido como uma ameaça à segurança internacional contra a qual deve-se agir imediatamente, correndo-se o risco de perder, no futuro, as habilidades de lidar com tal problema. A percepção dessa ameaça é a responsável por fazer o tema securitizado ser inserido na agenda de segurança (Buzan, Waever, \& Wilde, 1998). Foi este o processo seguido ao longo do século XX e começo do século XXI que permitiu o vínculo entre segurança internacional e desenvolvimento.

${ }^{43}$ Este é o exercício que Sindjoun (2002) fez e usou como argumento para justificar uma leitura estadocêntrica das relações internacionais na África.
} 
O segundo motivo é que segurança e desenvolvimento são conceitos relativos e derivados. Isto é, diferentes concepções, atitudes e comportamentos dos atores associados aos termos podem ser rastreados e identificados de acordo com a corrente de teoria política que seguem. Isto quer dizer que "como alguém pensa sobre segurança e desenvolvimento depende das premissas que ele tem sobre a natureza humana e sobre as unidades, estruturas e processos significantes que caracterizam a política mundial" (Spear \& Williams, 2012, p. 10). Neste sentido, os entendimentos sobre segurança e desenvolvimento seriam tão diversos e calcados em teorias já consolidadas que dificilmente uma contribuição nova surgiria, à exceção de estudos críticos destinados mais ao debate sobre os conceitos do que à criação de alternativas às políticas ora implementadas. O número especial Special Section: What is 'Human Security'? da revista Security Dialogue (2004) é um exemplo quase caricato. Este trabalho pretende, então, utilizar uma abordagem corriqueira mais na política internacional do que na academia para auferir o vínculo entre segurança e desenvolvimento.

O terceiro e último motivo que induz a acreditar que a fusão entre desenvolvimento e segurança é problemática é o fato de que há percepções distintas e, por vezes equivocadas, sobre ambas as esferas e conceitos. Isto se dá porque as pessoas e as sociedades geralmente "perseguem valores distintos, têm diferentes tolerâncias com o perigo (ou seja, resiliência), e possuem habilidades desiguais para lidar com os desafios do desenvolvimento" No caso do desenvolvimento, deve-se entender grupos podem ter diferentes interpretações e entendimentos sobre quais condições podem ser-lhes adversas e, consequentemente, sobre como lidar com elas assim como, no campo da segurança, os diferentes níveis de tolerância aos riscos, que são definidos pelas experiências vividas pelas comunidades (Spear \& Williams, 2012, p. 11).

Isto quer dizer que o que constitui a pobreza pode claramente ser alvo de debate assim como o que constitui a violência. Por um lado, saber ler e escrever, por exemplo, pode ser extremamente necessário para as condições de vida em grandes centros urbanos como São Paulo, Paris ou Nova Iorque, porém pode ser completamente inútil em comunidades e tribos afastadas no interior do Sudão, do Tadjiquistão e nos locais mais remotos da Amazônia. Por outro lado, pessoas vivendo em Caracaraí, Roraima (cidade brasileira com a maior taxa de homicídios por 100 mil habitantes em 2014), podem entender os riscos às suas vidas e prevenir-se de modo diferente do que pessoas regularmente sujeitas a explosões, como em Bagdá, ou que vivem em locais de 
permanente guerra civil como em Mogadíscio. Em todos estes casos, de alguma forma, as pessoas continuam a viver e a aperfeiçoar suas habilidades a fim de tornar gerenciáveis os elevados riscos sob os quais vivem.

Se estes motivos estiverem certos, por que houve tanto esforço durante os séculos XX e XXI para vincular causalmente subdesenvolvimento e guerras intraestatais? A resposta parece residir precisamente na construção do consenso neoliberal que se consolidou a partir dos anos 1980. A perspectiva de que desenvolvimento e segurança estão íntima e causalmente ligados não só ignora a controvérsia relativa aos tais conceitos como também, da forma que foi feita, exclui os países do chamado Primeiro Mundo da responsabilidade direta pelas causas, mas inclui-os na solidariedade de reconstruir os países afetados pelos conflitos e pelo subdesenvolvimento. Isto é, o rechaço às teses terceiro-mundistas e a incorporação do ideário neoliberal nos programas e agências das organizações internacionais acabaram reduzindo tal problema à mera inadequação de instituições e de políticas econômicas, o que só poderia ser resolvido - mesmo que com pressões externas - pelos atores internos.

Há vários estudos que, ao contrário, indicam que os esforços para ajustar as políticas econômicas por parte dos países da África Subsaariana (em particular) tiveram consequências não intencionais e opostas ao que era esperado. Várias tentativas de Estados africanos de implementar políticas já adotas por países ocidentais ou não surtiram o efeito esperado, provando-se completamente inócuas para aquela realidade, ou tiveram um efeito desestabilizador tanto econômico quanto político. Sobre os efeitos econômicos, o economista William Easterly (2001) apresentou uma série de dados que provam que muitas das políticas desenvolvimentistas exigidas pelo Ocidente ou copiadas do Ocidente na África Subsaariana geraram resultados muito longe dos esperados. Alguns dos exemplos citados são inquietantes. $O$ investimento em capital físico e na educação e seus pífios resultados no continente são apenas dois exemplos de que adequar as políticas econômicas e sociais ao exemplo ocidental não é a solução.

Isto talvez explicaria o porquê de a Nigéria ter tido crescimento per capita anual de $-1,5 \%$ entre 1981 e 1998 . O aumento de $250 \%$ no estoque de capital físico por trabalhador entre 1960 e 1985, semelhante ao de Hong Kong no mesmo período, gerou apenas um acréscimo de $12 \%$ na produtividade por trabalhador (contra 328\% em Hong Kong). A Gâmbia é outro caso emblemático: aumentou seu estoque de capital físico em 
$500 \%$ nesse período, mas a produtividade por trabalhador aumentou apenas $2 \%$. Além delas, a Tanzânia talvez seja o caso mais dramático. O capital por trabalhador no setor manufatureiro cresceu 8\% por ano entre 1976 e 1990, mas a produção por trabalhador caiu 3,4\%. O que é interessante nestes casos, é que o baixo (ou negativo) crescimento na produtividade, isto é, a falha no desenvolvimento não gerou forçosamente conflitos intraestatais: a Tanzânia e a Gâmbia, que constam na lista dos PMDs respectivamente desde 1971 e 1975, nunca passaram por conflitos intraestatais.

Algo semelhante também foi dito sobre a educação. Países como Madagascar, Moçambique, Níger, Nigéria, Sudão e Zâmbia eram desastres em números de matrícula nos anos 1960, mas apresentaram significativas melhoras em 1990. Entretanto, não se viu reflexos dos investimentos em educação no crescimento econômico neles e na média da África Subsaariana. Enquanto o crescimento em capital educacional da região cresceu pouco mais de $4 \%$ entre 1960 e 1985, seu PIB per capita cresceu apenas 0,5\% no mesmo período $^{44}$. No geral, países africanos que tiveram acelerado crescimento em capital humano nesse período como os supracitados além de Angola, Gana e Senegal, foram os mesmos cujas taxas de crescimento econômico foram desastrosas. Além disso, o fato de Angola, Moçambique, Níger, Nigéria, Senegal e Sudão terem experimentado conflitos domésticos após este período poderia sugerir hipóteses ingênuas de que os investimentos em educação criaram situações propícias ao conflito, o que não pode ser crível uma vez que países - como Comores e Guiné-Bissau - que não tiveram melhorias na educação foram palco de conflitos igualmente. ${ }^{45}$

Outra área em que a adaptação das políticas e instituições gerou resultados inesperados ou indesejados foi com os programas de ajuste estrutural dos anos 1980. Estes conjuntos de políticas designados para reformar as economias dos Estados endividados do Terceiro Mundo foram elaborados a partir dos chamados Estados desenvolvidos e de organizações internacionais tais como o Banco Mundial e o FMI, mas se assemelhavam em conteúdo. De certa forma, todos eles exigiam reformas dos Estados do Terceiro Mundo que garantisse a liberalização econômica e uma economia orientada para o mercado por meio do controle dos orçamentos deficitários e da oferta de moeda e da

\footnotetext{
${ }^{44}$ Pritchett (1999), citado por Easterly (2001).

${ }^{45}$ Nem Comores nem Guiné-Bissau chegaram a ter guerras civis desde a conclusão de seus respectivos processos de independência. O primeiro foi palco de conflitos não-estatais em 1998 e o segundo viu a violência política escalar a conflitos menores entre 1998 e 1999.
} 
liberalização do regime de câmbio. Tais reformas estavam em acordo com as exigências econômicas dos anos 1980 e começo dos anos 1990 e consoantes com os mecanismos os quais se supunha fossem capazes de gerar o desenvolvimento.

Os relatórios Accelerated Development in Sub-Saharan Africa de 1981 e Africa's Adjustment and Growth in the 1980s de 1989 representaram bem esse novo momento econômico. O segundo, especificamente, afirmava que aqueles Estados que haviam adotado as medidas do ajuste e da reforma econômicos conseguiram administrar melhor suas economias do que aqueles que não o haviam feito. Desde o começo dos anos 1980, países como Quênia, Malaui, Maurício e Senegal já estavam passando pelos primeiros ajustes. Uma década depois, praticamente toda a África Subsaariana havia aderido a tais programas. As consequências, contudo, foram trágicas para a grande maioria dos Estados africanos.

Os efeitos trágicos causados pelo processo de reestruturação da economia global e a crise econômica que começara na década anterior foram agravados nos anos 1980 devido à globalização dos mercados financeiros e à queda abrupta dos preços das commodities, o que contribuiu para uma violenta queda nas exportações dos países africanos. Neste cenário, as já frágeis e irregulares economias africanas foram obrigadas a recorrer ao FMI e ao Banco Mundial assim como a outras instituições financeiras e doadores internacionais. Em troca do empréstimo ou auxílio econômico que necessitavam, os países africanos tiveram que implementar uma série de medidas relativas à desvalorização monetária, liberalização comercial, corte de subsídios e no orçamento, privatização das fazendas e empresas estatais etc.

Embora se argumente que tais instituições não tenham tido efeitos profundos e influência sobre decisões domésticas feitas pelos líderes africanos e do resto do Terceiro Mundo, as prescrições dos programas de ajuste estrutural culminaram em desastres financeiros, econômicos e principalmente políticos nos Estados da África Subsaariana. De modo geral, os Estados africanos tiveram que desvalorizar suas moedas significativamente durante os anos 1980, o que resultou no progressivo fim dos mercados cambiais paralelos, uma das mais óbvias distorções econômicas no continente, até meados dos anos 1990 uma vez que a moeda não era mais um produto valioso (Herbst, 2000, p. 223). Além disso, as exigências de privatização das empresas tiveram um impacto profundo sobre a base patrimonialista dos regimes, que dependiam da 
distribuição dos benefícios para manter-se no poder devido à sua total falta de legitimidade (Clapham, 1996).

Os ajustes estruturais daquela década desafiaram, acima de tudo, o Estado patrimonial na África. Apesar de isto parecer um efeito positivo, o colapso deste tipo de Estado está diretamente conectado ao colapso do próprio Estado. Ao desafiar o controle dos governantes e Estados sobre a economia doméstica, as instituições internacionais que promoveram e exigiram os ajustes desafiaram a própria consolidação dos Estados africanos uma vez que desafiaram as bases políticas e econômicas do monopólio sobre a estatalidade, que garantira às elites governantes a possibilidade de extrair os recursos econômicos para manter-se no poder e para distribuí-los de modo a ganhar apoio político. Em outras palavras, os ajustes estruturais alteraram a distribuição de recursos alocativos e autoritativos de tal modo que desafiaram o Estado neopatrimonial na África. Desta forma, os Estados africanos tiveram de intensificar a repressão contra as dissidências já que não conseguiam mais cooptá-las pela persuasão ou distribuição de benefícios. Os efeitos dos ajustes estruturais talvez sejam a conexão mais clara existente entre a distribuição de benefícios econômicos e a estabilidade política (Clapham, 1996; 1998b).

Ainda que os programas de ajuste estrutural tenham exercido influência direta no prejuízo sobre o estado patrimonial e a distribuição dos benefícios econômicos nos Estados da África Subsaariana, é importante ressaltar que tais prejuízos não foram reproduzidos no desenvolvimento dos Estados: comparados aos níveis de desenvolvimento de 1990, apenas 11 dos 44 Estados analisados da região estavam piores passados dez $\operatorname{anos}^{46}$ e apenas 4 passados vinte $\operatorname{anos}^{47}$. Destes, Burquina Faso, Gabão e Zimbábue não apresentaram conflitos domésticos entre 1990 e 2011. No geral, a grande maioria dos Estados da África Subsaariana apresentou melhorias após os programas de ajuste estrutural dos anos 1980, inclusive aqueles que foram palco de conflitos intraestatais. Os ajustes, aparentemente, foram responsáveis pela melhoria dos índices de desenvolvimento do continente e também pela origem das guerras na África Subsaariana durante os anos 1990.

\footnotetext{
46 Angola, Burquina Faso, Comores, Congo, República Democrática do Congo, Gabão, Guiné-Bissau, Quênia, Serra Leoa e Zimbábue.

${ }^{47}$ Chade, República Democrática do Congo, Serra Leoa e Zimbábue.
} 


\subsection{Considerações finais}

Ora, o que se percebe, portanto, é que as falhas desenvolvimentistas medidas pela perspectiva preponderante sobre o desenvolvimento (renda, recursos humanos e vulnerabilidade econômica) não estão relacionadas com a ocorrência de conflitos intraestatais na África Subsaariana. Ademais de ter sido fruto da construção de um consenso imposto em um momento neoliberal da economia, a fusão entre segurança e desenvolvimento não deve ser levada como garantida. Ao que tudo indica, ela deve ser entendida como uma forma em que os agentes econômicos internacionais encontraram para continuar suas ações e em que os países do chamado Primeiro Mundo se desvincularam da responsabilidade de reconstrução e ajuda aos seus congêneres periféricos. Parece ser, portanto, em outra variável que os conflitos intraestatais africanos têm sua gênese. Guiados pelos efeitos que os ajustes estruturais causaram na distribuição de recursos autoritativos e alocativos, argumentar-se-á no próximo capítulo que as variações na autoridade estatal são as responsáveis para a eclosão das guerras e para a escalada da violência nos Estados da África Subsaariana. 


\section{Construção de autoridade como construção de Estado}

No capítulo anterior, buscou-se demonstrar que o vínculo entre as esferas de desenvolvimento e segurança não passou, na verdade, de uma criação política do século XX e que foi reverberada nos círculos acadêmicos, dando-lhe fundamentação científica. A construção de tal vínculo ocorreu em um processo de criação de consenso a partir dos anos 1980 e que ganhou força principalmente na década seguinte, após o fim da Guerra Fria e na virada do século, quando o assunto dos Estados frágeis e falidos tornou à tona devido aos atentados terroristas de 11 de setembro de 2001. Além disso, argumentou-se também que as causas das guerras intraestatais na África Subsaariana, principalmente no período pós-Guerra Fria tinham suas origens em outra variável que não o desenvolvimento. Neste capítulo, analisar-se-á o papel da autoridade estatal na garantia da segurança interna dos Estados daquela região e na consolidação dos mesmos.

Como já dito, entende-se por autoridade a percepção que os atores de um Estado têm sobre a eficiência da governança estatal, da nomocracia e da ausência de violência política naquele Estado. De modo geral, esta perspectiva de autoridade está ligada ao entendimento de que o Estado deve ser capaz de criar e implementar políticas e legislação vinculante sobre seu território e seus cidadãos e sancionar aqueles que as violarem. Este capítulo apresentará os motivos pelos quais se pode afirmar que a autoridade e o desenvolvimento de um Estado ou são separadas ou que a primeira submete a segunda e qual a relação que guarda com a ocorrência de conflitos intraestatais.

\subsection{A autoridade estatal como viabilizadora do Estado}

Os dados coletados indicam que a chave para compreender os conflitos intraestatais assim como para dar conta da falência de Estados na África Subsaariana pode estar na relação entre a autoridade estatal e o desenvolvimento dos Estados daquela região. Apesar de 65\% dos casos analisados entre 1996 e 2011 estarem na mesma categoria para autoridade e desenvolvimento, estas são duas variáveis pouco parelhas de modo geral quando se analisa a correlação entre elas: apenas oito dos 44 países apresentaram correlações altas e positivas entre autoridade e desenvolvimento (Angola, República do Congo, Djibuti, Gana, Guiné Equatorial, Libéria, Moçambique e Ruanda), dos quais quatro apresentaram conflitos intraestatais neste período (Angola, República do Congo, Libéria e Ruanda). Além disso, é digno de nota que metade dos países analisados apresentou correlações negativas entre as duas variáveis. Por outro lado, apenas quatro 
Estados (Benim, Comores, República Centro-Africana e Gabão) apresentaram correlações altas e negativas entre as duas variáveis em questão. Estes dados reforçam a hipótese de que o desenvolvimento dos Estados e a autoridade estatal comumente não seguem os mesmos caminhos.

O que é interessante sobre estes dados é que eles apontam para a necessidade de entender autoridade e desenvolvimento de modo em separado para a análise da África Subsaariana, visto que as altas correlações foram encontradas apenas em um pequeno número de Estados da região. Dado que no capítulo anterior argumentou-se que o subdesenvolvimento não é a causa de conflitos na África Subsaariana e que a promoção do desenvolvimento nos países da região tampouco produziu efeitos pacificadores, é importante deixar claro que estes dados enfatizam a necessidade de um estudo mais detalhado acerca da autoridade estatal na região e sua ligação com a origem dos conflitos intraestatais daquela região. No mais, eles geram mais perguntas do que respostas quando o assunto é a eclosão das guerras domésticas. O que explica estes dados? Indicam que os conflitos surgirão quando um Estado não tem bom desempenho tanto na autoridade como no desenvolvimento? Ou que a incompatibilidade entre os recursos e a governança - e não simplesmente a falta de recursos - os gera?

O que as histórias de Ruanda e Libéria durante a década de 1990 (e também de Angola e República do Congo, conforme será demonstrado no capítulo 5) sugerem é que tanto a eclosão dos conflitos como o assentamento das tensões que a eles levaram estavam ligadas às crises de autoridade estatal e às disputas pelo comando do Estado e que o nível de desenvolvimento pouca relação teve com a eclosão ou com o término da guerra. Um dos principais indícios disso é que Angola e Gana, por exemplo, estiveram na mesma categoria de desenvolvimento em todo o período entre 1990 e 2011, o que não aconteceu com a autoridade. Estes casos servem, portanto, para que se averigue a existência de uma causalidade entre os níveis de autoridade e desenvolvimento e entre os primeiros e a ocorrência de conflitos intraestatais. Ruanda e Libéria são ilustrativas neste ponto: seus conflitos começaram logo no final da Guerra Fria e serviram de exemplo para as principais explicações sobre a falência de Estados no continente e para a eclosão de conflitos domésticos em seus Estados. Geralmente, as explicações sobre seus conflitos que se baseiam nas incompatibilidades étnicas de seus povos, isto é, concentram sua 
atenção na agência e não na estrutura. Os gráficos 2 e 3 demonstram a evolução do desenvolvimento entre 1990 e 2011 e da autoridade nos dois países entre 1996 e $2011 .^{48}$

Em um extremo das correlações, encontram-se Ruanda e Libéria, países cujos níveis de autoridade e desenvolvimento evoluíram no mesmo sentido entre 1996 e 2011, principalmente após a conclusão de suas guerras civis. No outro, encontra-se a Costa do Marfim, país cujos níveis de autoridade e desenvolvimento seguiram caminhos opostos após o final da Guerra Fria, conforme mostra o gráfico 4. O golpe de Estado e a eclosão do conflito doméstico neste país foram visto como uma surpresa por muitos, devido à sua estabilidade de longa data.

Gráfico 2 - Evolução do desenvolvimento e da autoridade em Ruanda entre 1990 e 2011.

\section{RUANDA}

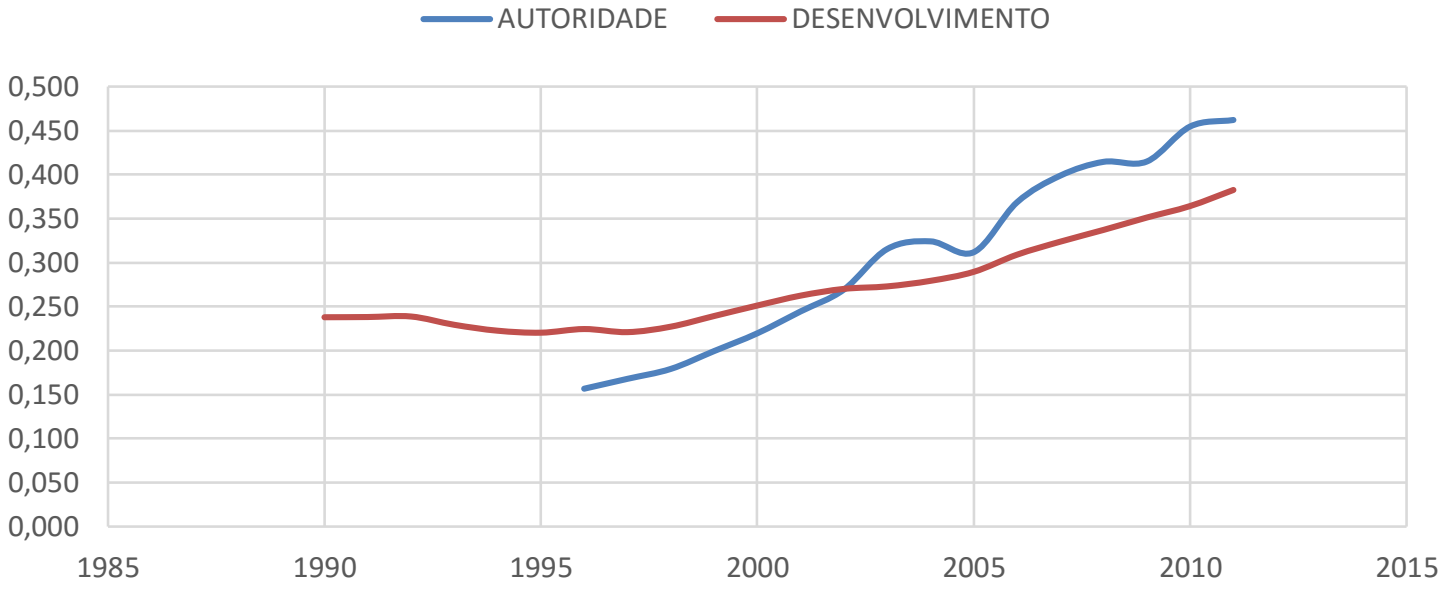

Fonte: Worldwide Governance Indicators (2014), Fondation pour les Études et Recherches sur le Développement International (2015). Elaboração própria.

${ }^{48}$ Tal como explicado na introdução, a autoridade estatal é composta pela ausência de violência política e terrorismo, pela nomocracia e pela eficácia da governança. O desenvolvimento, por sua vez, compreende a renda per capita, os recursos humanos e a vulnerabilidade econômica de um país. Há mais detalhes e informações no Apêndice I. 


\section{LIBÉRIA}

- AUTORIDADE DESENVOLVIMENTO

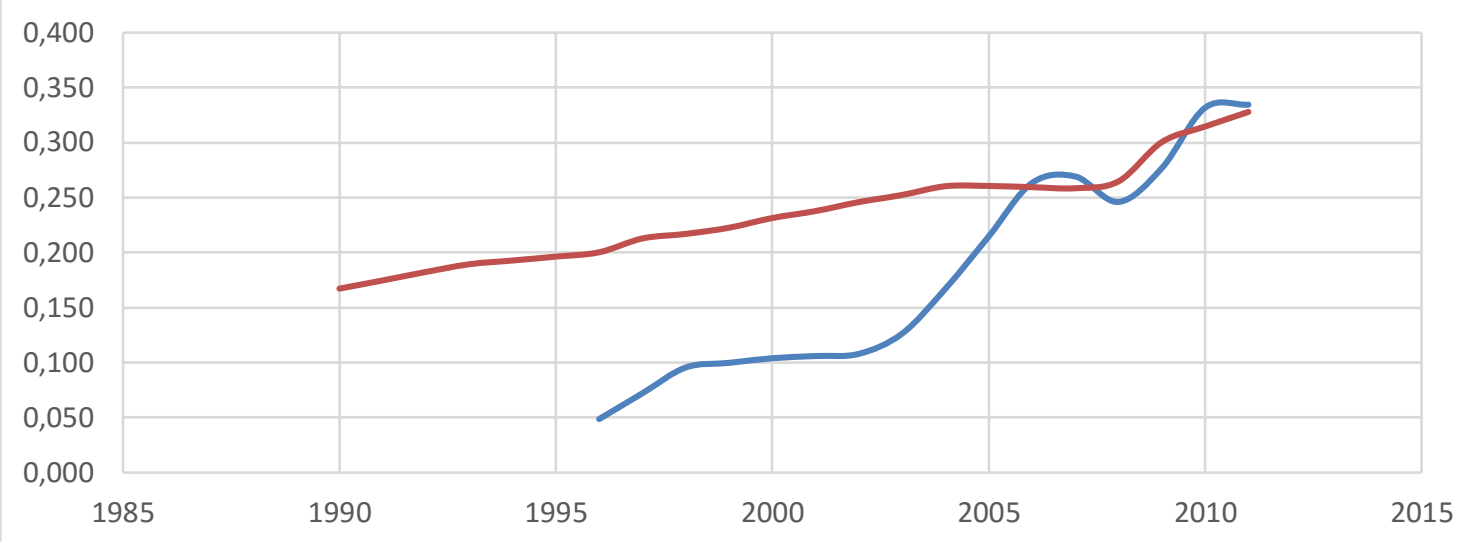

Fonte: Worldwide Governance Indicators (2014), Fondation pour les Études et Recherches sur le Développement International (2015). Elaboração própria.

Gráfico 4 - Evolução do desenvolvimento e da autoridade na Costa do Marfim entre 1990 e 2011.

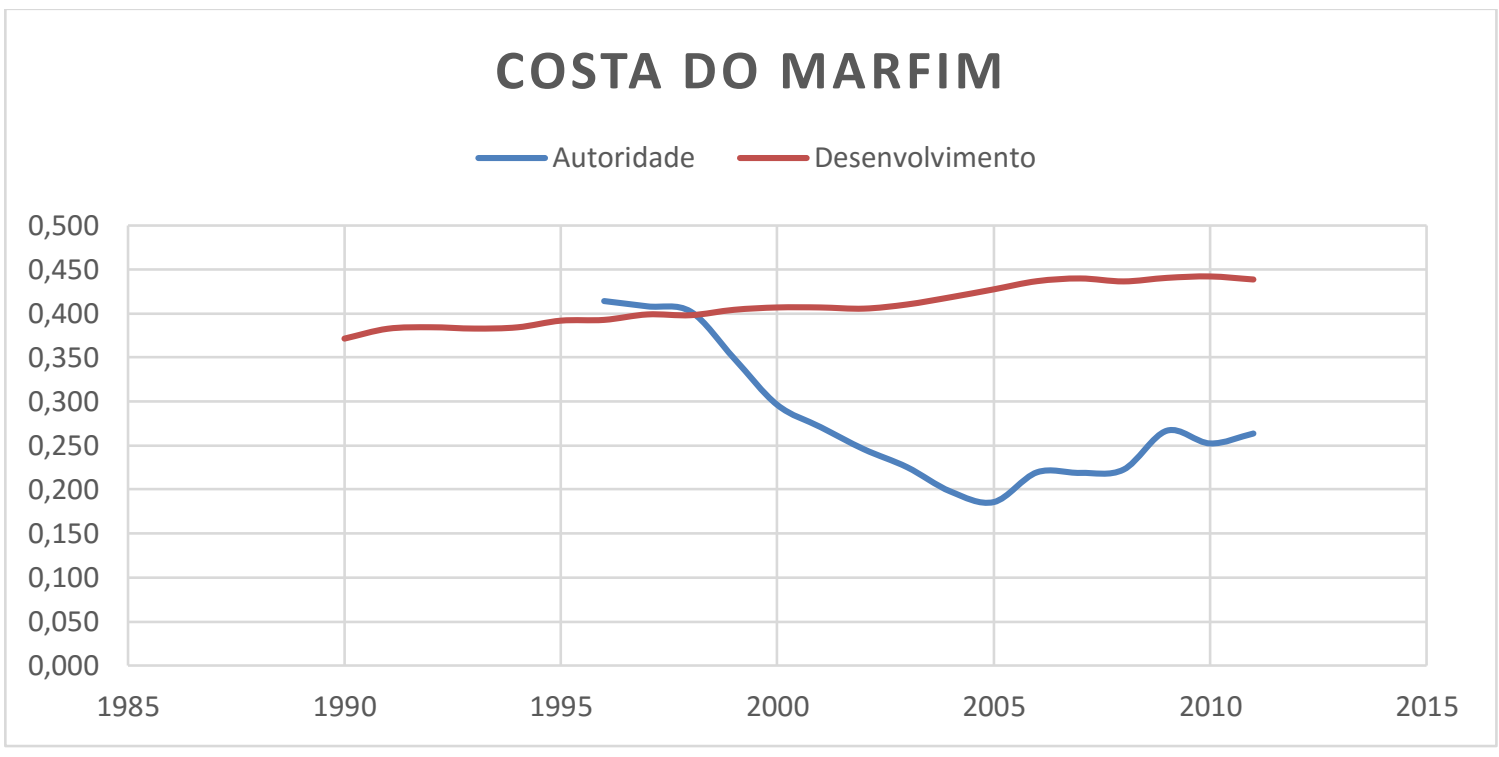

Fonte: Worldwide Governance Indicators (2014), Fondation pour les Études et Recherches sur le Développement International (2015). Elaboração própria.

No caso de Ruanda, a disputa pelo controle do Estado foi central na eclosão do conflito em 1991 que culminou no genocídio de abril de 1994. Nesta guerra, as partes tiveram total controle sobre técnicas de manipulação da opinião internacional. Após três décadas no exílio em Uganda, grupos tutsis que serviram ao exército daquele país durante 
os anos 1980 organizaram-se para retornar a Ruanda e retomar o poder que havia sido usurpado por facções hutus que derrocaram a monarquia ruandesa (tutsi) durante a Muyaga ${ }^{49}$, como ficou conhecida a Revolução hutu que ocorreu entre 1959 e 1961, e instituíram a república naquele país. Isolados e marginalizados no exército ugandês pelo então presidente Yoweri Musevini, os exilados passaram a tomar como objetivo principal seu regresso para Ruanda. Organizados sob a Frente Patriótica Ruandesa (FPR), os exilados retornaram para (invadiram) o país em um contexto de crescente instabilidade política. No momento, uma das questões chave a ser respondida era se a invasão representou o "retorno dos tutsis" em si ou se foi um aspecto mais amplo, uma consequência da resposta que o governo de Juvénal Habyarimana dava a cada vez pior situação política no país, isto é, uma "reação destinada a combater a inadequação de uma cultura política enraizada no tribalismo, na ditadura, no temor e no mito" (Huband, 2004, p. 237).

De todo modo, boa parte da instabilidade que se foi criando no começo dos anos 1990 deveu-se à estratégia política da FPR. Tal estratégia visou desestabilizar não só o regime de Habyarimana, mas também todo o conjunto hutu do país. Para levá-la a cabo, a Frente cometeu e com êxito fez acusar o regime de vários assassinatos políticos entre os anos de 1991 e 1994 assim como promoveu entre 1991 e 1992 dezenas de atentados sem objetivos ou alvos específicos com minas, granadas e outros armamentos e logrou culpar os chamados escadrons de la mort, homens fortes do regime de Habyarimana. Além disso, a FPR esteve diretamente envolvida na criação do grupo que deu o drama final e maior à guerra civil ruandesa: a milícia Interahamwe.

Associada ao Chefe do Estado-Maior de Ruanda o Coronel Théoneste Bagosora, que comandou o comitê de crise criado e instituído após o assassinato do presidente Juvénal Habyarimana, tal organização paramilitar foi responsável em fazer o "jogo sujo" que o governo ruandês não podia fazer para evitar problemas com a opinião pública internacional, isto é, o genocídio. Na sua criação estava Jerry Robert Kajuga, um tutsi, que virou ministro do governo de Paul Kagame (líder da FPR) ao fim da guerra. A FPR pretendia assim desempenhar um papel duplo: "provocar o caos a fim de criar o irreversível e desacreditar os Hutus aos olhos da opinião internacional” (Lugan, 2013, p. $334)$.

\footnotetext{
49،"Ventos de destruição" em quiniaruanda.
} 
Tal caos só seria possível atacando a fundação do poder hutu no país e minando a sensação de autoridade e de capacidade de implementar a ordem doméstica que o governo transmitia à população. Isto porque o país vinha obtendo importantes melhorias no plano desenvolvimentista durante o governo de Juvénal Habyarimana, considerado autoritário, porém afável. Entre 1976 e 1990, o PIB per capita do país cresceu significativamente e mostrou-se muito superior aos de seus vizinhos da região dos Grandes Lagos (Burundi, Zaire, Uganda e Tanzânia), a economia foi diversificada aumentando as atividades no setor secundário vis-à-vis no primário, logrou reduzir a mortalidade infantil e melhorar os indicadores de higiene e de cuidados médicos e fez crescer a proporção de crianças na escola, que era de 49,5\% em 1978 para 61,8\% em 1986 (Pruntier, 1995). Visto que o caos inexistia no país, a FPR foi obrigada a criá-lo. O desenvolvimento apenas tornou a crescer no país uma vez que foi posto término à guerra e o (novo) governo conseguiu restabelecer sua autoridade e a das instituições estatais.

Na Libéria, por sua vez, a disputa pelo poder desde o golpe de Estado promovido por Samuel Doe em dezembro de 1980 fragilizou ainda mais o já fraco arranjo institucional que havia sido criado pelos chamados "honoráveis", isto é, aqueles descendentes de escravos americanos que retornaram para a África durante o século XIX. Ainda que já houvesse uma disputa pelo poder entre os "honoráveis" e os "autóctones", o país logrou durante a presidência de William Tubman (1944-71) importantes avanços na construção do Estado e da nação liberiana. Foi durante este governo que inclusive aos autóctones foram concedidos direitos políticos tais como o voto (Novati \& Valescchi, 2005) e que o país atingiu a segunda maior taxa de crescimento econômico do mundo durante os anos 1950 (Marinelli, 1964), além dos importantes crescimentos na quantidade de crianças matriculadas na escola quem, em 1973, chegou a 13\% da população (Clapham, 2009). Além disso, mesmo a aproximação do conflito não representou a decadência desenvolvimentista desse país cujas instituições operavam e apresentavam resultados melhores do que outros países em desenvolvimento. De acordo com os indicadores de desenvolvimento do Banco Mundial (BM), em 1990 40\% dos liberianos tinham acesso a sistema de esgoto e 57\%, a água potável (Miller, 2013).

Esta imagem de estabilidade e prosperidade que a Libéria possuía antes do golpe de Estado e da consequente eleição de Doe à presidência do país cinco anos depois, no entanto, pode ser questionada. A estrutura do país vinha sendo "devorada pelos cupins da repressão política, desigualdade econômica e massivo mal-estar social", o que só não fez 
eclodir a guerra antes por causa do que ele chamou de "inibidores de conflito", isto é, repressão política, maciça rede de patrimonialismo, mitologia e a ação das forças armadas. "Os inibidores de conflito foram fundamentais para atrasar a aflição do país com as duas doenças gêmeas de decadência estatal e desintegração" (Kieh, 2008, p. 04). Durante os nove anos em que esteve no poder, Samuel Doe não soube manter esta estrutura que fora capaz de garantir a estabilidade no país por muitos anos o que permitiu, assim, as condições para que a Frente Patriótica Nacional da Libéria (FPNL), liderada por Charles Taylor, tomasse o poder pela força e fizesse eclodir a guerra que duraria até 1997, da qual saíra vitoriosa. Taylor ainda teria de enfrentar, a partir de 1999, o Liberianos Unidos pela Reconciliação e Democracia (LURD), apoiado pela Guiné e liderado por Charyee Doe, irmão do presidente deposto Samuel Doe.

A presença e a força dos "inibidores de conflitos" no país demonstram que a questão do subdesenvolvimento social e econômico não foi chave para a eclosão de nenhuma das duas guerras civis. Ainda que a desigualdade econômica e o mal-estar social tenham sido apontados como responsáveis por arruinar a estrutura política do país, é importante notar que as estreitas relações que o país guardava com os Estados Unidos, que por meio de investimentos e ajuda financeira, permitiram taxas crescentes de desenvolvimento durante os anos 1980 e 1990. Ora, sua importância estratégica para aquele país devia-se apenas à sua debilidade institucional e ao seu atraso de seu sistema de governo (Huband, 2004).

Pode-se afirmar assim que os inibidores de conflito não tiveram forças face à "patologia institucional” que assolava o país (Dolo, 1996). Isto é, a incapacidade das instituições públicas em desempenhar efetivamente as funções para as quais foram criadas gerou mais incentivos para o conflito do que os inibidores de conflito geraram para a manutenção do status quo. Dolo afirmava que as relações entre os três poderes no país eram, na verdade, de subordinação do executivo vis-à-vis o legislativo e o executivo. O resultado negativo desta soma era tão evidente que até Herman Cohen, secretário de Estado adjunto norte-americano de assuntos africanos (1988-1993) assumiu que "os liberianos tinham motivos legítimos para crer que devíamos [os EUA] assumir algum papel na guerra" (Huband, 2004, p. 121) uma vez que os americanos souberam explorála em acordo com seus interesses. Estando o governo liberiano incapaz de lidar com os desafios que confrontavam seu país, erigiu-se um forte ressentimento e uma forte 
hostilidade contra as elites que administravam as instituições públicas liberianas. O resultado disto só poderia ser o solo fértil para a eclosão da primeira guerra civil liberiana.

O caso marfinense ilustra muito bem como o desenvolvimento pôde e pode ser sacrificado em detrimento da autoridade e da estabilidade e como o desenvolvimento não garante melhorias na autoridade estatal. Ainda que careçam os dados sobre esta, os 33 anos de governo de Félix Houphouët-Boigny representaram um momento de pujança econômica - mas não de desenvolvimento - e de estabilidade política no país. Enquanto a primeira fora conseguida graças às suas alianças e relações com países do bloco Ocidental durante a Guerra Fria, em especial, com a França, fazendo com que o país tornasse-se "a vitrine do capitalismo africano", a segunda só foi possível devido à sua posição de "homem forte" no país. Assim como outros líderes no continente, HouphouëtBoigny exercia as funções de chefia do executivo e das forças armadas, de legislar assim como tinha influência forte e direta sobre o judiciário e tratou de "excluir e desclassificar possíveis competidores" (Novati \& Valescchi, 2005, p. 318). No caso desta última, o "pai da nação" marfinense fez Laurent Gbagbo fugir do país em 1982 após ter criado a Frente Popular Marfinense (FPM), partido de oposição.

Por mais que sua popularidade fosse frequentemente contestada, principalmente quando tratou de investir milhões de dólares na sua cidade natal e nova capital do país, Iamussucro, sua autoridade não chegou a ser questionada ou seriamente ameaçada até começo dos anos 1990, quando teve de ceder e convocar eleições multipartidárias. No começo dos anos 1980, a recessão econômica global e uma forte seca local derrubaram o preço do açúcar e sacudiram a economia marfinense, tendo impacto direto na dívida externa do país, o que não foi exclusividade sua. Além da Costa do Marfim, países com economia mais sólida como Quênia e Nigéria viram os pagamentos de suas dívidas subirem de $27 \%$ para $32 \%$ das receitas de suas exportações. Os impactos da crise e do ajuste estrutural, por outro lado, tiveram seus reflexos na política dos Estados africanos. Líderes puderam distribuir os valores emprestados entre seus aliados políticos enquanto os custos dos ajustes foram passados para o povo, que não tinha nenhuma influência política. "Na Costa do Marfim, o programa ajudou a liderança política a reimpor o controle sobre sua própria burocracia” (Clapham, 1996, p. 178).

Os níveis de corrupção e as dificuldades econômicas e sociais fizeram com que houvesse, em 1990, protestos e greves generalizadas de estudantes e funcionários 
públicos que pressionavam pela legalização de partidos oposicionistas - que passaram a receber apoio externo - e eleições livres, plurais e diretas. Na Costa do Marfim, Houphouët-Boigny concordou com a demanda da oposição por eleições imediatas e tratou de organizá-las antes mesmo que seus rivais pudessem representar qualquer ameaça. Desta forma, Henri Konan Bédié enfrentou uma oposição fragmentada e desorganizada e venceu com facilidade as eleições de 1995. No entanto, faltava-lhe a habilidade de seu antecessor para costurar apoios políticos, tendo que recorrer à opressão e à prisão de vários opositores. Durante seu mandato, sua popularidade decadente não acompanhou o crescimento econômico pelo qual o país passou.

Destarte, Bédié tratou de impedir a candidatura de Alassane Ouattara para as eleições do ano 2000. Dando ênfase na Ivoirité, Bédié fez aprovar um ato que excluía milhares de pessoa da nacionalidade marfinense ${ }^{50}$, inclusive Ouattara (de origem burquinabesa), que fora o último primeiro-ministro de Houphouët-Boigny. As eleições, contudo, foram precedidas por um golpe militar em dezembro de 1999, que depôs Bédié e empossou o General Robert Guéï. No escrutínio, o general enfrentou Laurent Gbagbo, que havia sido feito candidato pelo presidente deposto. Sem Ouattara no caminho, que tinha apoio forte em distritos que somavam cerca de $35 \%$ do eleitorado nos quais houve altíssima taxa de abstenção, Gbagbo, que tinha apoio de cerca de $42 \%$ do eleitorado, derrotou Guéï e foi eleito presidente do país. Além das acusações de fraude, sabe-se que a participação em alguns distritos, onde o presidente eleito tinha maior apoio, foi de quase 100\%. "Para 70\% dos marfinenses, o novo presidente era então ilegítimo e a contestação aumentou", dando origem à guerra civil naquele país (Lugan, 2013, p. 299). ${ }^{51}$

Estes três casos (Ruanda, Libéria e Costa do Marfim), principalmente, são importantes para ilustrar primeiro que autoridade e desenvolvimento não evoluem necessariamente juntos e, quando o fazem, é aquela que cria condições para as variações neste. Ora, as constantes melhorias no desenvolvimento durante os anos 1980 e 1990 não foram capazes de evitar os conflitos em nenhum dos três casos. Além disso, Ruanda e Libéria - países que tiveram alta e positiva correlação entre desenvolvimento e autoridade - trilharam caminhos extremamente distintos para a reconstrução após seus conflitos:

\footnotetext{
${ }^{50} \mathrm{O}$ norte do país era povoado por muitos descendentes de imigrantes serra-leoneses e liberianos. $\mathrm{O}$ ato aprovado por Bédié exigia que uma pessoa devesse ter ambos os progenitores nascidos na Costa do Marfim para ter direto à nacionalidade marfinense.

${ }^{51}$ Segundo a quantidade de mortos e as classificações do UCDP, o conflito na Costa do marfim não chegou a ser uma guerra civil, ficando apenas na categoria de conflitos menores.
} 
enquanto a primeira sacrificou a democracia e utilizou-se forte centralização do poder para atrair investimentos externos, a segunda democratizou-se com auxílio da missão da ONU e conseguiu investimentos graças aos contatos internacionais de sua presidente (Mills, 2014). Em ambos os casos, a paz apenas voltou quando houve a quase total supressão de uma das partes beligerantes ou a percepção de que nenhuma das partes seria capaz de ganhar a guerra: a FPR tomou o poder em Ruanda ainda em 1994 e lá permanece até o presente, enquanto a Libéria de Charles Taylor ainda passaria por uma segunda guerra civil, resultado do mau assentamento institucional e da má distribuição de poder entre os atores da cena política nacional. Esses dois países, assim como Angola, demonstram que a autoridade estatal é capaz de resgatar e impulsionar o desenvolvimento do país. O fim da longa guerra civil no país lusófono em 2002, só foi possível quando o Movimento Popular para a Libertação de Angola (MPLA) impôs derrota militar significativa à União Nacional para a Independência Total de Angola (UNITA) que culminou, inclusive, na morte de seu líder, Jonas Savimbi. É justamente após tal fato que o movimento marxista-leninista conseguiu garantir o controle efetivo do país e de suas instituições que o desenvolvimento passou voltou a crescer, principalmente, com a exploração de petróleo offshore.

O fato de a grande maioria dos países na África Subsaariana não apresentar correlações altas e positivas entre autoridade e desenvolvimento e que metade deles apresentam correlações negativas entre as duas variáveis confirma as teses de Acemoglu e Robinson (2010; 2012), Chabal e Daloz (2001), Englebert (2000a; 2000b) e Moss (2011) de que os governantes na África Subsaariana comumente tiveram de escolher entre aprimorar seu governo e poder ao "compartilhar o botim" com aliados políticos ou implementar políticas desenvolvimentistas. A lógica imbuída aqui é de que os governos costumam ser tão ilegítimos que apenas logram garantir apoio político pelo loteamento de cargos. É intrigante neste sentido, o fato de que todos os 11 países os quais tiveram conflitos intraestatais ente 1996 e 2011 - com a exceção do Burundi e do Chade apresentaram fortes tendências de crescimento e melhoria no desenvolvimento antes da eclosão dos conflitos e mantiveram-nas depois, o que, na maioria dos casos, não foi acompanhado por mudanças na autoridade ${ }^{52}$. Destarte, estes dados parecem sugerir que, ao contrário do que preza a corrente que vincula desenvolvimento e segurança, promover

\footnotetext{
52 As tendências de melhoria no desenvolvimento desses países era real. A tendência de 12 deles apresentava um coeficiente de determinação maior que 0,85 enquanto a dos outros seis era maior que 0,625 .
} 
o desenvolvimento em países subdesenvolvidos tem potencial para gerar conflitos intraestatais neles desde que seus benefícios sejam distribuídos de maneira desigual, tal como sugeriria a teoria da privação relativa.

Seguindo o argumento proposto por tal teoria, as pessoas que forem privadas de bens materiais e imateriais tais como capital, empregos, justiça, privilégios etc. revoltamse contra a ordem vigente e contra aqueles que a mantêm uma vez que tal privação se percebe na comparação com o que outros têm ou com o que os revoltosos já tiveram ou podem ter no futuro. É a partir desta comparação a outros indivíduos ou grupos e dos agravos dela derivados que surgem as causas para os movimentos sociais que, em situações extremas, levam a violência política como motins, terrorismo e guerras civis (Boudon, 1977; Gurr, 2011a). A privação relativa aplica-se não só a indivíduos em suas relações intragrupos, mas também às relações entre os grupos. Neste sentido, a posição social desfavorável de um grupo com relação a outro poderia levar gerar tensões entre eles.

Gurr (2011a), em sua tentativa de entender os protestos e as rebeliões que ocorreram no fim dos anos 1960, apresentou um modelo que levava em consideração a privação relativa; as justificativas ou crenças sobre elas e a utilidade das ações políticas das pessoas; e a balança entre a capacidade de ação dos descontentes e a capacidade do governo em reprimir ou canalizar o descontentamento popular. No entanto, o próprio autor admitiu - quarenta anos depois - que seu modelo tem duas limitações. A primeira é que ele não incorpora a identidade dos grupos que, segundo o autor, "é fundamental para compreender o grupo de referência das pessoas, seu sentimento de injustiça coletiva e sua suscetibilidade aos apelos para a ação política". A segunda é que o modelo falha ao presumir a irracionalidade daqueles que reagem com violência ao seu senso de injustiça sob a justificativa de que as consequências de tais reações costumam ser mais destrutivas que construtivas. Para o autor, não se pode definir à priori a ausência de racionalidade em tais ações uma vez que "elementos de racionalidade permeiam todo o processo de conflito político" (Gurr, 2011b).

A correção destas duas falhas torna mais claro seu argumento sobre as respostas que os governos dão às ações políticas e como aquelas - e não estas - são os determinantes principais que levam à violência contra as autoridades. Desta forma, desigualdades entre os grupos impostas pelo governo e a negação do direito de usar a política convencional 
costuma criar condições propícias para o surgimento de terrorismo, revoluções e resistência armada (Gurr, 2011a). Este seria, portanto, o caso dos regimes de segregação racial que assolaram países como a África do Sul, a Namíbia e a Rodésia. O fato de governos poderem responder às demandas populares reprimindo-as ou fazendo-lhes concessões podem contribuir, respectivamente, à eclosão de revoltas e rebeliões ou a um estado de maior paz social. Em ambos os casos, está em jogo a capacidade (e as estratégias) de os governos implementarem e exigirem o cumprimento a suas políticas e leis, ou seja, está em jogo sua autoridade.

Além dele, Bayart (2006) apresentou em sua tese sobre a "política do ventre" uma abordagem bastante profícua para capturar não só a essência da política nos Estados da África Subsaariana, mas também para compreender como estes parecem ser mecanismos chave para a manutenção de determinados grupos no poder. Utilizando-se de termos gramscinianos, Bayart afirmou que o bloco histórico ${ }^{53}$ que surgiu nos Estados africanos logo após suas independências não constituiu uma classe dominante, mas no máximo uma classe em processo de formação que se envolveu na busca pela hegemonia. Tal processo permitiu que ocorresse naqueles países a chamada "revolução passiva", isto é, a promoção da mudança social e econômica através da assimilação recíproca das elites nos setores público e privado. Desta forma, ao invés de identificarem-se com as categorias na base da pirâmide social, os evolués continuaram usando a máquina que lhes permitia acumular poder.

A disputa pela hegemonia nos Estados da África Subsaariana trouxe, segundo o autor, cenários que variaram entre a "modernização conservadora" e a "revolução social", o que permitiu o advento de centralizações monárquicas (Burundi e norte da Nigéria), trajetórias baseadas em linhagem (Camarões, Costa do Marfim e República do Congo) e governo de minorias exógenas (Quênia durante a colonização, Rodésia, Angola, Moçambique, Zanzibar e Serra Leoa). No geral, estes cenários intermediários configuraram-se um tipo de situação na qual a assimilação recíproca das elites serviu como um vetor para a "revolução passiva" e forneceram as fundações para o Estado póscolonial, o qual ele chama de "Estado Rizoma", uma vez que permite redes subterrâneas (isto é, ilegais e extra-institucionais) de laços familiares e facções e de patrões e clientes.

\footnotetext{
${ }^{53}$ Conjunto da estrutura e da superestrutura, ou seja, as relações sociais de produção e seus reflexos ideológicos.
} 
É assim que - continua o autor - as redes rizomáticas fecham o ciclo entre as sociedades africanas e as instituições pós-coloniais. A precariedade dos equilíbrios nacionais não seria, portanto, resultado da inadequação orgânica Estado às sociedades africanas nem mais uma prova de seu caráter exógeno, mas sim "de sua estreita simbiose com os terroirs que o sustentam". A construção de uma ordem política pós-colonial, assim, consistiu na criação de uma rede capaz de dar poder e autonomia ao presidente que, nos casos limite, conseguiu sua preponderância absoluta "eliminando política e fisicamente seus rivais e renunciando à lógica da assimilação recíproca das elites" (Bayart, 2006, p. 273). O uso destas redes políticas que caracterizam o Estado Rizoma é uma das formas de não só os governantes, mas também os Estados garantirem sua perpetuação no poder - o que não se faz sem autoridade.

Os dados coletados entre 1996 e 2011 sobre a autoridade do Estado e a percepção que atores têm sobre ela apontam no sentido de que esta é indispensável para garantir a estabilidade e paz internas aos Estados africanos, ainda que às vezes tenha de ser conquistada em detrimento do desenvolvimento dos mesmos. Neste sentido, quase metade dos países que foram palco de conflitos intraestatais ou não-estatais apresentou tendência decrescente de autoridade em todo o período, como também todos eles apresentaram problemas com os níveis de autoridade e viram quedas significativas neles nos períodos que antecederam a eclosão do conflito. ${ }^{54}$ Em outras palavras, tais Estados já estavam falindo, pois estavam falhando em desempenhar suas funções mais básicas (segurança e regras) e estavam aderindo forçosa e (quiçá) voluntariamente cada vez mais ao regime de soberania negativa.

Estes dados também - é importante ressaltar - indicam a ampla heterogeneidade que existe entre os Estados da região também em seus níveis de autoridade e na percepção que seus atores têm sobre ela, tal como ilustrado na figura 1 . Na verdade, tanto estes como outros índices e medições sobre os desempenhos dos Estados da África Subsaariana indicam para grandes diferenças no exercício da soberania empírica. Isto significa que houve diferentes graus de adesão ao regime de soberania negativa. Assim sendo, é mister que se leve em consideração que os Estados da região apresentem variedades que vão além do binarismo "com conflito doméstico" e "sem conflito doméstico". Essas

\footnotetext{
${ }^{54}$ Chade, Comores, Costa do Marfim, Guiné, Mali, Mauritânia e Sudão. É importante ressaltar que a autoridade estatal no Mali e na Mauritânia apresentou leve tendência decrescente (inclusive com baixíssimo coeficiente de determinação).
} 
diferenças, principalmente para os países que foram palco de guerras intraestatais, são bastante visíveis no que concerne a duração e a gravidade dos conflitos e indicam, portanto, diferentes tipos e graus de falência estatal.

Foi por esse motivo que Call (2008; 2010); Carment, Prest e Samy (2010); e Miller (2013) trataram de designar diferentes categorias de falência que se baseavam, principalmente, em diferentes aspectos que compunham os Estados (tal como já foi explicado na introdução deste texto). Das categorias que estes criaram, há uma importante porção delas que está diretamente ligada à existência de conflitos domésticos. Call é um bom exemplo que ilustra como a relação da segurança está mais relacionada à falência e fragilidade estatal do que qualquer outra função que se possa atribuir ao Estado. Nas quatro categorias que ele sugeriu em seu artigo de 2008, nota-se a relação entre a falência de Estados e a ocorrência de conflitos domésticos (Estados colapsados, Estados com capacidade institucional formal fraca e Estados devastados pela guerra) e a relação entre os níveis de autoridade Estatal e a ocorrência destes conflitos (Estados/regimes autoritários). Igualmente, sua percepção no artigo publicado dois anos depois demonstra como a "lacuna na segurança" dos Estados é mais comum em casos de Estados falidos do que as lacunas na legitimidade e na capacidade.

Neste sentido, é possível afirmar que a falência de um Estado está ligada à sua capacidade de fornecer a segurança contra ameaças externas e, quiçá principalmente, a ordem e a segurança domésticas. Em outras palavras, um estado falido é um estado em que a guerra se tornou característica da rotina de seus habitantes e que o próprio governo é alvo de grupos armados e parte do conflito. Esta é a percepção dos mais variados índices que visam medir o desempenho dos Estados. É no mínimo sugestivo, por exemplo, que em 2015 nove dos dez países listados como os mais frágeis do mundo - e oito dos dez países africanos pior classificados - pelo Fund for Peace estejam em guerra doméstica ou recuperando-se de conflitos encerrados recentemente ${ }^{55}$. Além disso, apenas quatro dos dez países do mundo pior colocados no indicador "pobreza e declínio econômico"

\footnotetext{
${ }^{55}$ No caso dos países africanos, Sudão do Sul, Somália, República Centro-Africana, Sudão, República Democrática do Congo, Chade, Nigéria e Costa do Marfim estão entre aqueles que estão em guerra civil ou recuperando-se de conflito doméstico recente. Guiné e Zimbábue completam a lista dos dez Estados africanos mais frágeis do mundo segundo tal ranking.
} 
estavam também listados entre os 10 mais frágeis do mundo. ${ }^{56} \mathrm{~A}$ mesma proporção acontece para os países africanos. ${ }^{57}$

Por mais que exista uma suposta necessidade de "transformar os Estados em Dinamarca" e que esta seja o grande desejo da Comunidade Internacional, há igualmente uma hierarquia entre as características principais que compõem essa "Dinamarca". Este desafio, contudo, é de execução bastante difícil uma vez que as instituições não foram criadas do dia para a noite e guardam um elevado grau de complexidade que refletem os valores culturais das sociedades nas quais foram criadas e estão inseridas. No entanto, é possível resgatar e identificar elementos comuns a todas as sociedades que desenvolveram instituições políticas.

Fukuyama (2005; 2011), por exemplo, escreveu sobre como a diminuição do escopo dos Estados - proposta pelos programas de ajustes dos anos 1980 - afetaram negativamente sua força. Isto gerou uma nova demanda por instituições nos países principalmente do chamado Terceiro Mundo e requereu a reconstrução de instituições e, consequentemente, de Estados. A diminuição dos Estados e, até mesmo, a existência de sociedades com Estados mínimos ou inexistentes já era uma realidade que apenas foi intensificada por aqueles programas. A baixa capacidade de arrecadar impostos e, por conseguinte, a existência de sistemas débeis de justiça e polícia permitiu que ironizasse ao afirmar que "muitas partes da África Subsaariana são o paraíso de um libertário" (Fukuyama, 2011, p. 28). Ao usar a caótica situação da Somália (país que não tem um governo central realmente efetivo desde 1991) e da Nigéria (incapaz de proteger os direitos de propriedade intelectual de sua intensa indústria de cinema), Fukuyama lembrou que a primeira instituição política criada foi justamente o Estado - cuja função é a garantia de segurança e de aplicação da lei - seguido do Estado de Direito (capaz de constranger os governantes a não violarem as leis que eles mesmos criaram) e do Governo Responsável (democracia).

Seguindo esta linha de pensamento, Migdal (2011, p. 67) compilou uma série de problemáticas acerca dos elementos constitutivos do Estado e afirmou que um Estado fraco seria "quase impotente em um turbilhão de mudanças sociais [...] em grande medida independentes de todo impulso do Estado". Em sua tese, o autor ecoou a percepção de

\footnotetext{
${ }^{56}$ Sudão do Sul, Somália, Iêmen e Afeganistão.

${ }^{57}$ Sudão do Sul, Somália, Sudão e Guiné.
} 
Huntington (1968) de que a principal distinção que existe entre os Estados não é o tipo de governo, mas sim o governo que realmente governa. Deste modo, o autor concordou com Fukuyama e apontou para o fato de que, em muitos casos, o maior problema não é que haja muita autoridade, mas pouca.

A discussão que se inaugura a partir de então é se tal perspectiva sobre os Estados, isto é, se sua função primeira é a garantia de segurança externa e ordem doméstica, vale também para a África Subsaariana ou se apenas é reflexo de experiências ocidentais (principalmente europeias). Afinal, há uma vasta literatura que critica a aplicação de modelos universalizantes uma vez que foram criados com base em realidades geoepistemológicas específicas. A obra de Fukuyama (2011) intitulada As Origens da Ordem Política, por exemplo, sequer menciona experiências e trajetórias da África Subsaariana (com a exceção de um comentário mínimo sobre a Etiópia) e, do mesmo modo, há uma corrente de pensamento bastante forte que afirma que as tradições (e instituições) africanas teriam evoluído para formas bem distintas das que têm hoje caso não houvesse havido ou se pudessem ir além do encontro colonial (Mamdani, 1996; Adjaye \& Misawa, 2006).

Outra crítica que aponta neste sentido é a análise da historicidade dos Estados africanos feita por Jean-François Bayart (1996; 1999; 2006). Ele faz coro às denúncias feitas ao fato de que literatura jornalística ou acadêmica repete ad nauseam a hipótese "da marginalização do subcontinente ou de sua "desconexão" e assim "reproduz o estereótipo hegeliano do isolamento desta parte do planeta" (Bayart, 1999, p. 01). Talvez pior do que isto - de acordo com o autor - seja o fato de que nenhuma das teorias ou dos modelos de análise aplicados à região tenha sido elaborada com base em estudos profundos e minuciosos de sua realidade, dado que "o continente, decididamente, nunca foi o epicentro das ciências do político" (Bayart, 2006, p. 24).

Isto é um problema dado que historicidade do Estado pós-colonial tem o poder de refutar a Teoria da Dependência, o conceito de etnicidade e a análise de classes. Para ele, nenhum destes constitui unidade de análise pertinente. Além disso, Bayart (2006, pp. , 24) queixa-se das periodizações que dividem e caracterizam a história da região foram produzidas exogenamente, com base no mundo ocidental e re-enfatizam a dependência da região: "a continuidade das formações históricas africanas no longo prazo é obscurecida, enquanto a penetração europeia adquire relevância decisiva”. 
O uso de modelos e teses não-africanas - e corriqueiramente ocidentais - para a análise dos Estados africanos e de suas funções tem sido frequentemente criticado por uma série de autores. De certo modo, isto se deve ao fato de que não apenas suas periodizações foram feitas tomando como base acontecimentos históricos que lhe eram estranhos, mas também pelo fato de que tais análises pressupõem certo determinismo e assumiam que as sociedades chegarão todas um dia a um mesmo patamar e padrão. É neste sentido que Clapham (2000) e Herbst (2000), por exemplo, refutaram a aplicação do modelo de Tilly (1990) para a África.

Este tratou de identificar as variações no tempo e no espaço entre as formas dos Estados europeus e o que fez com que convergissem a Estados Nação. Mesmo admitindo que os países Europeus não tivessem passado por processos uniformes, eles foram moldados por duas forças principais: coerção e capital. Eles foram determinados pela necessidade de ir à guerra, o que impulsiona seus governantes a extrair recursos de algum lugar, originando os Estados Nação uma vez que os recursos não podiam ser prontamente traduzidos em potencial de guerra. Foi a relação entre a coerção e o capital que determinou, entre outras coisas, a necessidade de contrapartidas e prestação de contas dos governantes para com sua população. Vista sob este ângulo, a própria fraqueza dos Estados africanos estaria explicada. Contudo, outras variáveis para a formação dos Estados na África Subsaariana foram indicadas. Por um lado, Herbst (2000, p. 13) afirmou que "a experiência africana de política em meio a grandes quantidades de terra e baixas densidades demográficas enquanto enfrentava um ambiente fisicamente inóspito" representava um claro contraste às experiências europeias de construção de Estados. Por outro, Clapham (2000) apresentou motivos bastantes convincentes pelos quais se pode afirmar que o fim da Guerra Fria deu lugar a condições novas e que, a partir de aí, não se pode afirmar que a relação entre do capital e da guerra com a formação dos Estados possa ter levado a um mesmo tipo de instituição.

É neste sentido que uma boa parte dos estudos sobre o Estado na África está direcionada. A rejeição de modelos teóricos e políticos para a construção dos Estados encontra respaldo em uma ríspida crítica que trata de combater a ideia de que a África é o terroir no qual o resto do mundo (principalmente as potências) agem e que ignoram, portanto, as trajetórias históricas concretas existentes no continente tais como a dos reinos de Madagascar ou da costa angolana e que foram os eventos dos dez primeiros anos após 
o fim da Guerra Fria que "corroboraram com a instrumentalização do constrangimento externo pelos detentores do poder ou outros atores políticos” (Bayart, 1999, p. 101).

Figura 1 - Ordem dos Estados em termos de autoridade média entre 1996 e 2011

\begin{tabular}{|l|}
\hline Maurício \\
\hline Botsuana \\
\hline Cabo Verde \\
\hline Seicheles \\
\hline Namíbia \\
\hline África do Sul \\
\hline Gana \\
\hline Benim \\
\hline Lesoto \\
\hline Gâmbia \\
\hline São Tomé and Principe \\
\hline Senegal \\
\hline Gabão \\
\hline Maláui \\
\hline Moçambique \\
\hline Mali \\
\hline Mauritânia \\
\hline Zâmbia \\
\hline Madagascar \\
\hline Tanzânia \\
\hline Burquina Faso \\
\hline Suazilândia \\
\hline Níger \\
\hline Djibuti \\
\hline Uganda \\
\hline Camarões \\
\hline Togo \\
\hline Quênia \\
\hline Eritreia \\
\hline Ruanda \\
\hline Guiné Equatorial \\
\hline Etiópia \\
\hline Comores \\
\hline Serra Leoa \\
\hline Guiné-Bissau \\
\hline Costa do Marfim \\
\hline Zimbábue \\
\hline Congo \\
\hline Nigéria \\
\hline Chade \\
\hline Guiné \\
\hline Angola \\
\hline Rundia \\
\hline \\
\hline Congo Centro Africana \\
\hline
\end{tabular}

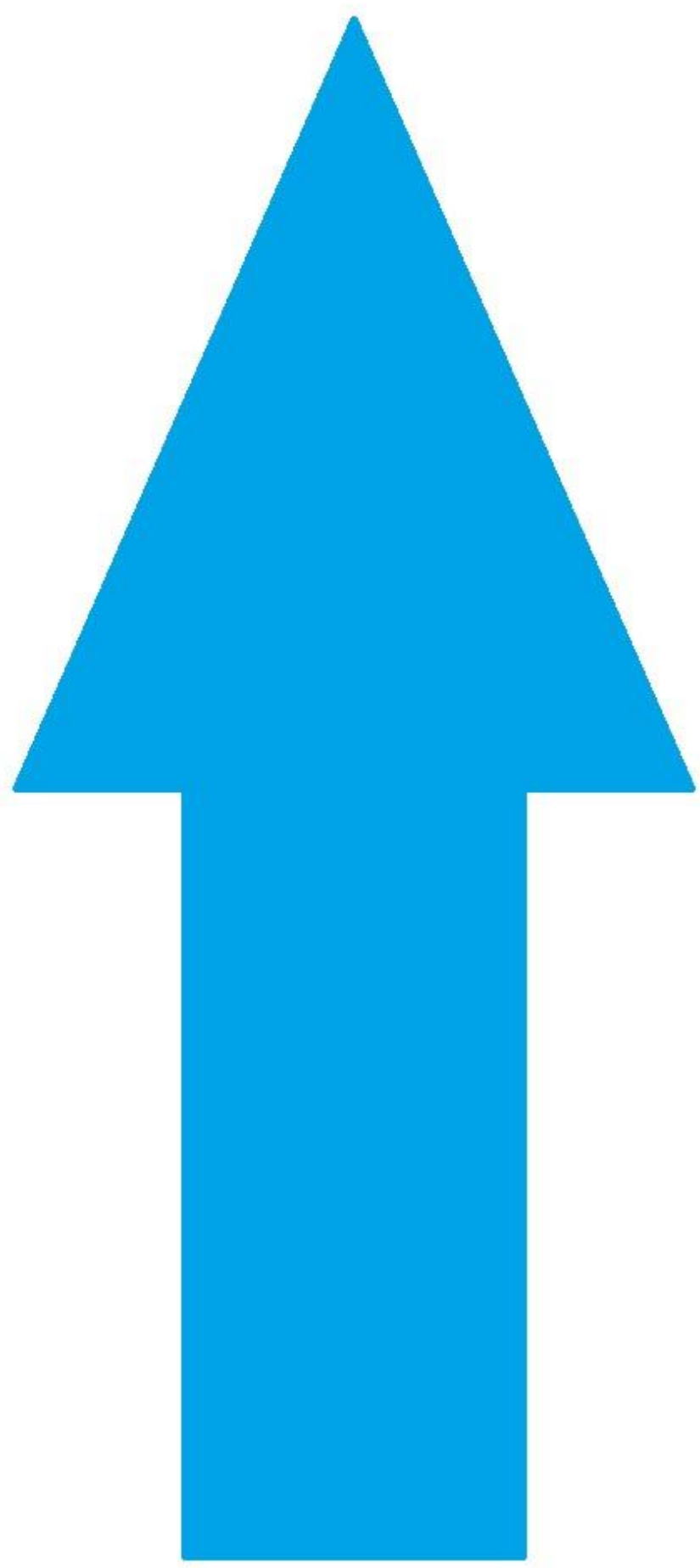

Fonte: Worldwide Governance Indicators (2014), elaboração própria. 
Se esta crítica estivesse por inteiro correta, poder-se-ia imaginar que a falha na universalização do modelo weberiano de Estado, ou seja, que a presença de Estados falidos seria "a revanche de uma cultura concebida como dominada sobre uma cultura apreendida como dominante" e que "à lógica da hibridização se opõem então com violência aquela da rejeição da recomposição identitária" (Badié, 1992, p. 223) ${ }^{58}$. Entretanto, há ainda assim elementos comuns às polities da África Subsaariana que existiram antes da colonização, das quais muitas continuaram a existir após as independências disputando, na prática, o poder e a autoridade com os Estados formais.

O que houve realmente de imposição e de universalização foi o componente territorial do Estado, que se pretende ser fixo, e não a importação de todo um modelo de organização social e institucional. As características mais elementares do Estado (governo, instituições e povo) e suas funções (a garantia da segurança e da ordem domésticas) representam o ponto em comum das polities do mundo. Os Estados, ou as polities que a eles se assemelham, guardam importantes semelhanças entre si. Como disse Migdal (2011), os Estados funcionam em dois ambientes. Por um lado, no âmbito mundial, no qual o Estado - por meio de seus funcionários - interage com outros e com grandes empresas, organizações internacionais e vários atores transnacionais. Por outro, os Estados funcionam em âmbito doméstico, sendo composto e relacionando-se com sociedade que pretende governar. Não se pode afirmar, contudo, que tais características tenham sido impostas ou que só foram do conhecimento dos povos da África Subsaariana após a colonização em nenhum dos casos.

Afirmar que os Estados pós-coloniais da região desempenham (ou tentam desempenhar) as funções externas do Estado não é difícil nem polêmico. Eles se relacionam entre si e com outros Estados do mundo; são membros e participam de várias organizações internacionais tanto de alcance regional como global; estão integrados à economia mundial uma vez que fazem parte do comércio mundial e são locais onde diversas empresas estrangeiras atuam; relacionam-se de um modo ou de outro como uma série de atores transnacionais que varia de organizações não-governamentais a grupos terroristas. A discussão mesmo sobre as funções externas do Estado na África Subsaariana encontra-se nas polities do período pré-colonial e na suposta imposição das funções domésticas. Caso conclua-se que tais funções não sejam alienígenas à dinâmica

\footnotetext{
${ }^{58}$ Citado em Bayart (1996).
} 
política da região, será possível afirmar a continuidade da política do período pré para o pós-colonial e assim rechaçar hipóteses pós-coloniais tais como a de Mamdani (1996) que afirma que a colonização foi um divisor de águas na forma em que o poder era exercido na África.

\subsection{A historicidade e a atualidade do Estado na África Subsaariana}

Tal questão é prescindida pela discussão da historicidade do "Estado" na região. $\mathrm{O}$ argumento que defende que as instituições ocidentais foram impostas ao continente induz à conclusão de que os colonizadores encontraram povos que eram tabulas rasas, sobre os quais se poderiam criar quaisquer tipos de instituições e costumes. Isto pode até ser verdade - em parte - para colônias nas quais não havia assentamento humano prévio tais como Cabo Verde e São Tomé e Príncipe, arquipélagos desabitados até a chegada dos portugueses, respectivamente em 1460 e $1470^{59}$. No restante, contudo, a colonização não foi um processo ex nihilo. Suas criações, inclusive, foram alvo de "múltiplos processos de re-apropriação da parte dos grupos sociais autóctones” (Bayart, 1996, p. 09).

A hipótese da "continuidade das civilizações" do historiador Fernand Braudel, por exemplo, auxilia o entendimento deste fato. Baseia-se na ideia de que os eventos e revoltas não são capazes de pôr termo às civilizações, dado que estas são históricas e sempre incompletas e que atravessam trajetórias políticas que, na verdade, não passam de tipos ideais. "As civilizações sobrevivem às convulsões políticas, sociais, econômicas e até ideológicas que elas comandam insidiosamente e, às vezes, poderosamente" (Braudel, $1985)^{60}$. Por esta razão, podem-se identificar entidades estatais e civilizações na África pré-colonial que eram fortemente estruturadas e diretamente ligadas aos conflitos contemporâneos de Moçambique, Angola, Chade e Sudão, por exemplo.

Os chamados Estados tradicionais ${ }^{61}$, ou seja, os Estados que existiram antes da colonização européia na África Subsaariana também se encaixavam nestas funções de

\footnotetext{
${ }^{59}$ Afirma-se que pode ser verdade apenas em parte uma vez que os colonos que foram levados para os arquipélagos carregavam consigo - assim como todos os povos - culturas, valores e costumes os quais são a base para a interação e para o julgamento de instituições e povos estranhos.

${ }^{60}$ Citado em Bayart (1996, pp. , 15).

61 O termo "Estado tradicional" é usado aqui para designar as polities existentes na África antes da colonização, isto é, o "Estado pré-colonial". Ambos os termos são problemáticos. O primeiro, ao usar o termo "tradicional" como oposição ao Estado "moderno", demonstra uma linguagem evolutiva e induz a concluir que a modernidade apenas teria chegado ao continente com a chegada do homem branco. $\mathrm{O}$ segundo, por sua vez, trata a chegada dos europeus ao continente e a colonização da África como um divisor de águas na história do continente e trata os Estados que lá existiam antes da colonização como semelhantes e homogêneos, ignorando as centenas (quiçá milhares) de anos de sua existência e as
} 
interação com outros Estados e demais atores nacionais e transnacionais. Ainda que renomados autores como Hans Morgenthau e Robert Jackson ${ }^{62}$ tenham seguido a tradição hegeliana e afirmado que a África era, antes da colonização, um espaço politicamente vazio e ocupado por entidades muito mais afeitas à Antropologia do que às Relações Internacionais, abundam exemplos sobre Estados e cidades-estados que lá havia antes da chegada dos europeus e que com eles mantiveram relações políticas e comerciais.

É neste sentido em que se pode denunciar que, longe de ser passiva na sua relação com relação ao Ocidente, a África desempenhou um papal bastante ativo na definição de sua dependência com relação a este e que tal fato antecedeu a intensificação de suas relações assimétricas com as potências imperialistas no fim do século XIX. Esses Estados tradicionais africanos nunca deixaram de ter relacionamentos políticos e comerciais com outras entidades políticas africanas ou de alhures. Já havia, inclusive, um sistema econômico mundial do qual eles faziam parte mesmo antes da expansão mercantilista e capitalista do Ocidente. As rotas comerciais berberes que ligavam os mercados da África Subsaariana com os portos do Mediterrâneo, por exemplo, são claras ilustrações dessas relações do mesmo modo que a integração das cidades-estados da costa suále como Zanzibar (na atual Tanzânia) e Mombaça (no atual Quênia) com polities da Península Arábica e da Índia representavam o poder comercial destes naquele sistema econômico que perduraria até meados do século XIX.

Além das especiarias, as cidades-estados da Costa Suaíle eram importantes entrepostos para o comércio de escravos, assim como os reinos do Kongo e do Benim e o Império de Oió, na costa atlântica do continente. Desconhecendo o terreno e cientes dos custos da interiorização e da dominação, os europeus utilizaram-se das relações políticas e sociais daqueles Estados tradicionais para participar do comércio de escravos. Deve-se admitir, portanto, que "a África participou voluntariamente do comércio de escravos, sob os auspícios de dirigentes africanos" uma vez que os europeus não tinham recursos nem econômicos nem militares para forçá-los a vender escravos (Thorton, 1998, p. 125) ${ }^{63}$. Tal participação dos Estados tradicionais africanos neste comércio e sua integração com o sistema econômico mundial de então era tão forte que seu interesse na manutenção do

mudanças que ocorrem naturalmente em qualquer instituição política em tanto tempo de existência. Por falta de termo melhor, mas ciente e de acordo com estas críticas, este trabalho usará o termo "Estados tradicionais".

${ }^{62}$ Morgenthau (2003) e Jackson (1990).

${ }^{63}$ Citado em Bayart (1999). 
volume deste comércio os faziam engajar, na medida do possível, nos acontecimentos políticos ultramarinos. Foi o Reino do Benin - e não os Estados Unidos - o primeiro a reconhecer a independência do Brasil (Serrano \& Waldman, 2007).

Essas relações políticas e econômicas dos Estados tradicionais estendiam-se além da questão do comércio de escravos e eram bastante presentes entre eles e seus congêneres europeus e de alhures. A definição das fronteiras do Império Etíope no fim do século XIX e no começo do século XX são apenas um exemplo que se pode destacar neste sentido. Mesmo que esta seja considerada por muitos como uma exceção à regra na África Subsaariana devido a sua centralização política, a Etiópia representa como líderes dos Estados tradicionais africanos foram capazes de relacionar-se e de negociar diretamente com os países da Europa. É importante notar, neste contexto, como tal país foi capaz de apresentar uma resposta à expansão imperialista e à corrida colonial que se organizava sobre o continente naquele momento.

Após a aproximação e ações colonizadoras por parte da Itália na região da atual Eritreia no fim do século XIX, o imperador etíope Menelik II passou a intensificar o processo de centralização do poder e modernização política do país e começou a uma importante expansão territorial sobre as regiões não-abissínias de Ogaden e Harar uma vez que a Itália tinha como objetivo a colonização não só dos territórios que hoje correspondem à Somália, mas também da própria Etiópia. “A reorganização territorial concluída pelo Imperador Menelik [...] permitiu dizer que a Etiópia participou do scramble compartilhando de suas intenções" (Novati \& Valescchi, 2005, p. 241). Ainda que pela perspectiva do governo da época, tais ações tenham sido tomadas como modo de defesa contra o avanço imperialista, argumenta-se que, na verdade, a Etiópia foi tão imperialista quanto as potências europeias naquele momento. De todo modo, o uso de suas funções externas permitiu não só que o Império Etíope da época triplicasse o tamanho de seu território entre 1865 e 1890 como também celebrasse acordos que o delimitassem e estabelecesse suas fronteiras com a Eritreia (colônia italiana) em 1900, 1902 e 1908 (Negash \& Tronvoll, 2000; Woodward, 2003).

Embora tenha sido uma das poucas a elaborar mapas, a Etiópia não foi a única que teve de se preocupar com suas fronteiras e, assim, deixar claro que o princípio de territorialidade era inerente à sua política. Muitos outros povos localizados em diferentes e distantes pontos do continente também indicavam sua preocupação com o território e 
exerciam seus direitos sobre ele de modo comum. O Império Axânti - que em seu auge chegou a ter 11 milhões de habitantes - caracteriza um outro exemplo de que a territorialidade importava para os Estados tradicionais da África Subsaariana. Sua percepção sobre o exercício político pautava-se no fato de que "os direitos sobre a soberania eram distinguíveis do exercício de autoridade” (Wilks, 1975, p. 191) ${ }^{64}$. Para a lei axânti, a terra poderia pertencer a uma pessoa enquanto o povo que a ocupasse pertencesse a outra: as províncias meridionais, por exemplo, pertenciam ao Asantahene (título conferido aos imperadores axântis) enquanto seu povo estivesse sob o jugo dos Fanti ou do governador britânico. Os nunus (que viveram no que hoje seria o território da República Democrática do Congo) também se relacionavam com o território de modo similar ao que "distinguiam entre os guardiões da terra e os guardiões do povo". Neste caso, um pedaço de terra que não fosse ocupado pelo seu guardião poderia ser usado por estrangeiros que continuariam a ser governados pelo seu próprio líder, desde que "reconhecessem o controle ritual do guardião original sobre a terra" (Harms, 1987, p. $220)^{65}$.

Além destes, as fronteiras também eram objeto de atenção e recebiam tratamento semelhante em uma série de outros Estados tradicionais tais como o Califado de Socoto, os Emirados de Bauchi e Kano e os reinos Iorubá. O princípio da territorialidade presente de algum modo no tipo ideal hodierno e ocidental de Estado também já se fazia presente nos Estados da África pré-colonial e era extremamente funcional. Tal como atualmente, as fronteiras separavam polities e não culturas, etnias ou grupos linguísticos. Desde modo, não só pode-se afirmar que houve a continuidade das funções externas dos Estados período pré-colonial para o período colonial e posteriormente para o pós-colonial como também, para usar as palavras de Döpcke (1999, p. 81), “é importante sublinhar que, para o continente como um todo, a fronteira 'importada' não representava uma novidade absoluta".

$\mathrm{Na}$ verdade, tanto as fronteiras como o princípio da territorialidade não representavam nenhuma novidade, pois elas eram os fatores que e viabilizavam, de certo modo, as funções domésticas dos Estados tradicionais e avisavam aos estrangeiros de sua validade naquele território. Os diários dos viajantes europeus na África durante o século XIX, por exemplo, sempre indicavam a presença de fronteiras e os diferentes domínios

\footnotetext{
${ }^{64}$ Citado por Herbst (2000, p. 40).

${ }^{65}$ Id. Ibid.
} 
sobre a terra. Via de regra, percebiam que haviam saído da zona de jurisdição de um governante e entrado na de outro toda vez que necessitavam pagar impostos e taxas de trânsito (pedágio) para o governante daquela polity: "o controle político era simbolizado por estes dois poderes, taxar e dar justiça, e eles eram definitivamente confinados entre fronteiras" (Döpcke, 1999, p. 79).

O princípio da territorialidade não esteve relacionado apenas com as funções externas dos Estados tradicionais da África Subsaariana. Ainda que de modo um pouco distinto dos padrões ocidentais, era este quem determinava as possibilidades de exercício do poder e de governo. A Confederação Fanti, criada em 1871, talvez tenha sido o melhor exemplo de que a territorialidade era importante para o exercício das funções domésticas dos Estados mesmo antes da colonização no continente. Após uma guerra dos Estados fantis contra o império Axânti, aqueles decidiram unir-se em uma confederação de modo a juntar forças e proteger-se de possíveis ameaças futuras. Esta nova entidade política outorgou inclusive uma constituição escrita (a Constituição de Mankessim) que estabelecia como principais objetivos seus a promoção de relações amigáveis, as melhorias no país e a construção de estradas, uma vez que a integração física entre os Estados da confederação seria a única forma de difundir o poder e assim dar algum significado para o novo Estado. Além disso, a constituição ainda delegava para os reis e chefes de cada estado-membro o poder e a responsabilidade de cumprir e pôr em prática as decisões da assembleia nacional e do Rei-presidente. Deste modo, "tanto os requisitos físicos reais para estender a autoridade formal e precariedade absoluta para a difusão do poder foram prontamente reconhecidos pelos líderes pré-coloniais que compreenderam a geografia hostil que enfrentavam" (Herbst, 2000, p. 42).

As funções domésticas dos Estados podem ser identificadas em outros tantos Estados tradicionais da África Subsaariana, fortalecendo não só a hipótese da continuidade das civilizações, como também demonstrando que a figura do Estado não era exatamente uma novidade para os povos daquela parte do mundo. Tanto na concepção de que o Estado é composto e se relaciona com a sociedade que pretende governar quanto na ideia de que o controle político se resume ao poder de taxar e dar justiça (note-se que estas concepções não são excludentes, mas sim complementares), as funções domésticas dos Estados já eram cumpridas naquele continente, em maior ou menor grau, pelos Estados pré-coloniais e continuaram sendo-o pelos Estados hodiernos. 
Há um argumento bastante forte que aponta para a distinção entre as fronteiras dos Estados pré e pós-coloniais uma vez que naqueles o que realmente importava eram as pessoas e não a terra (ainda que esta continuasse tendo alguma importância). $O$ fato de que o direito de propriedade sobre as pessoas fosse altamente desenvolvido naqueles Estados indica que as relações interpessoais teriam sido base para a dominação política e para a jurisdição do Estado. Este argumento que defende que era o povo quem definia as extensões territoriais de um Estado na África pré-colonial e não o contrário foi reproduzido por Zartman (1965) e por Herbst (2000), entre outros. Seguindo esta linha de pensamento, o Estado africano originou-se da posse de circuitos espaciais e de fluxos de comércio. Em uma situação de baixa densidade demográfica e de altos custos para a difusão da autoridade e do controle político, os líderes dos Estados tradicionais da África Subsaariana reconheceram a importância de alvejar a população para exercer seu poder uma vez que a baixa produtividade agrícola gerava menos excedentes para serem taxados e elevava, assim, os custos fiscais. A consolidação da autoridade e do controle na África Subsaariana teria se baseado, então, mais sobre as pessoas dado que seria excessivamente oneroso fazê-la sobre certa extensão territorial.

A importância das pessoas na difusão do poder vis-à-vis a terra não contradiz o princípio da territorialidade. Primeiro pelo motivo de que de nada adianta uma polity bastante povoada se a população não tiver onde produzir os produtos de sua subsistência. Segundo, pelo fato de que os próprios Estados tradicionais da África Subsaariana conciliaram estes dois elementos na sua constituição. A mobilidade da extensão territorial daquelas entidades políticas só foi possível graças à ênfase da difusão do poder na população fez com que as divisões fossem muito mais alocadas e delimitadas, mas raramente fisicamente demarcadas. De todo modo, muitas vezes não era necessário que se o fizesse uma vez que geralmente eram fronteiras do tipo "zona".

Isto quer dizer que a organização e constituição dos Estados tradicionais africanos se dava muitas vezes por uma espécie de soberania graduada e compartilhada. Primeiro, a presença do Estado e sua autoridade eram sentidos com intensidade inversa à distância em que se estava de seu centro político, isto é, quanto mais longe se estava, menos se sentia a presença do Estado. Segundo, quanto mais se distanciava do centro político daquele Estado, maior era a necessidade de delegar o poder de coerção a outras chefias e lideranças que, em troca, pagariam tributos ao centro (Döpcke, 1999; Herbst, 2000). 
Os Estados da África pré-colonial eram organizados em três zonas. A primeira correspondia ao "Estado nuclear", isto é, o centro político e econômico do Estado, por onde passavam as principais rotas comerciais que garantiam sua vida econômica. A segunda, que circunscrevia a primeira, era uma zona constituída por chefias e lideranças locais que tinham o direito de taxar excedentes e cobrar tributos bem como de exercer poder e autoridade sobre a população que vivesse naquela zona desde que rendessem tributos para o Estado nuclear. Por fim, a terceira zona era constantemente sujeita a saques violentos (Grenzwilderniss) e, algumas vezes, caracterizada como terra de ninguém (Niemandsland). Esta estrutura estatal foi característica de boa parte da África Subsaariana até o século XIX. Apesar de esta estrutura em três zonas ter sido originalmente descrita como um fenômeno da África Austral, especificamente do Império de Monomotapa (localizado em extensões territoriais que hoje corresponderiam a Moçambique, Zimbábue, Lesoto, Suazilândia e África do Sul) e dos Estados Ndebele (localizados onde atualmente seriam a África do Sul, Botsuana e Zimbábue) ${ }^{66}$, é possível afirmar a soberania graduada e compartilhada era uma característica geral dos Estados da África Subsaariana até o século XIX.

No geral, os Estados tradicionais da África Subsaariana surgiram e variaram em tamanho e poder de acordo com a coerção que eles podiam infligir, a partir do centro, a seu povo e território. Até o século XIX, pelo menos, o crescimento (principalmente territorial) dos Estados da África Subsaariana dependeu das melhorias dos meios de coerção e de uso da força. "Por todo o período pré-colonial, os Estados africanos foram primorosamente concebidos em torno da quantidade precisa de autoridade que eram capazes de transmitir em áreas específicas" (Herbst, 2000, p. 52). Foi assim que os Estados tradicionais africanos passaram a ter capacidades para, entre outras coisas, exercer (e abusar) das noções de justiça que lhes eram inerentes. Nas áreas em que a coerção permitia a aplicação da autoridade estatal, havia, inclusive, a possibilidade de escapar da jurisdição de dado Estado transferindo-se para a de outro. Como lembrou Döpcke (1999, p. 79), "refugiados, e às vezes vilas inteiras podiam escapar da jurisdição de uma autoridade ao cruzar um rio ou uma floresta, e aqueles que fugiam da justiça poderiam ser acolhidos ou extraditados pelas autoridades que também tinham esta consciência".

\footnotetext{
${ }^{66}$ Beach (1980; 1986).
} 
Após o período colonial e as independências, os Estados africanos "modernos" continuaram a existir graças a um sistema de estatalidade que os protegia e lhes conferia rigidez territorial, mas que não alterava os custos de difusão do poder. Desta forma, estes novos Estados não precisaram esforçar-se para garantir sua existência e soberania. Além disso, a manutenção das fronteiras coloniais (rígidas) para o período pós-colonial combinado com a manutenção de um padrão de difusão de poder responsável justamente pela flexibilização do território dos Estados tradicionais criaram vácuos de poder nas hinterlândias dos Estados pós-coloniais.

A lógica apresentada aqui é de que quanto mais distante e remota a localidade com relação aos maiores centros urbanos (centro econômico e político do Estado), menos poder e autoridade central sentir-se-á. Isto se deve justamente a este encontro entre "tradição" do modo de difusão do poder e a "modernidade" das fronteiras dos Estados pós-coloniais: a autoridade e o controle continuaram a ser exercidas principalmente onde haveria algum tipo de retorno para o Estado, ou seja, nos maiores centros urbanos e não nas zonar mais remotas. Esta espécie de "retornos decrescentes em escala" do exercício da autoridade e do controle e sua incompatibilidade com a força atual das fronteiras dos Estados africanos indicam que o tamanho de seu território passou a importar para a governança do Estado, porém não do modo que seria esperado. Quando se trata em difusão de poder e autoridade na África Subsaariana, quanto menor o território do Estado, melhor a governança (Clapham, Herbst, \& Mills, 2006). Não à toa, três dos seis maiores Estados africanos estavam entre os dez países com os piores índices de autoridade em $2011^{67}$.

Neste sentido, pode-se dizer que a colonização não mudou grandes coisas nas dinâmicas políticas da África Subsaariana. Por mais que seja óbvio e evidente que os Estados tradicionais tenham deixado de existir e sido substituídos por novos Estados estes sim legados do colonialismo tardio - e que houve, no geral, a substituição das elites governantes, ainda é possível defender a ideia da continuidade na política da região. Trata-se, na verdade, de uma discussão sobre o exercício de poder que opõe o como contra

\footnotetext{
${ }^{67}$ Segundo Clapham, Herbst e Mills (2006), os Grandes Estados Africanos são aqueles que apresentam grandes proporções territoriais e demográficas. Seis países encaixaram-se nesta categoria: África do Sul, Angola, República Democrática do Congo, Etiópia, Nigéria e Sudão (a categoria foi criada antes da divisão entre Sudão e Sudão do Sul). Enquanto a África do Sul representa a grande exceção a este grupo, os demais apresentam grandes disfuncionalidades nos serviços do governo. No tocante aos níveis de autoridade de 2011, o Congo teve o segundo pior índice; o Sudão, o terceiro; e a Nigéria, o nono.
} 
o quem. Até o momento, deu-se especial atenção à forma como o poder era e é exercido nos Estados da África Subsaariana. De certo modo, tal perspectiva permite, entre outras coisas, concluir que, coeteris paribus, os governantes e líderes políticos estariam sujeitos às mesmas oportunidades e constrangimentos e, portanto, tomariam decisões semelhantes a qualquer momento.

Por outro lado, é importante pensar sobre "quem" exerce o poder e quais as consequências de uma mudança na liderança do Estado poderiam causar nas suas dinâmicas políticas. Tal discussão assumiria, por exemplo, que a ascensão ao poder por um grupo de visões opostas ao antecessor representaria uma grande mudança na política e nas políticas adotadas. Abundam exemplos que poderiam explicar tal diferença. A chegada ao poder da União Nacional Africana do Zimbábue - Frente Popular (ZANUPF) no Zimbábue em 1980, da Organização do Povo do Sudoeste Africano (SWAPO) na Namíbia em 1990 e do Congresso Nacional Africano (CNA) na África do Sul em 1994 representaram mudanças significativas nas respectivas políticas domésticas e externas. Nestes três países, tais mudanças representaram o fim definitivo dos regimes coloniais e de segregação racial que privilegiavam minorias brancas e inserção dos três países no sistema internacional com a independência dos dois primeiros e retirada de uma série de sanções que haviam sido aplicadas à última.

Também a Etiópia pode ilustrar tais mudanças. No primeiro caso, a proclamação da República em 1974, que depôs o Imperador Hailé Selassié I e faz ascender ao poder dos militares liderados por Mengistu Haile-Mariam, representou o fim do privilégio dado à capital e províncias amaras e inaugurou um período de 27 anos de regime socialista e antiamericano. Após a queda do Derg em 1991, a Frente Popular de Libertação do Tigré (FPLT) chegou ao poder prometendo a descentralização administrativa do país com base nas etnias, povos e nacionalidades existentes na Etiópia e permitiu, inclusive, a independência da Eritreia, que seria oficializada dois anos mais tarde.

Seguindo esta linha de pensamento que põe ênfase em quem - e não como - exerce o poder, o processo de colonização merece destaque. Os interesses econômicos das potências europeias sobre o continente, movidos pelo fim da escravidão e pela depressão na indústria têxtil inglesa entre 1861 e 1865, conhecida como a "Fome do Algodão de Lancashire", motivaram-nas a tentar colonizar o continente e garantir assim mão-de-obra, matérias primas e novos mercados consumidores. Para fazê-lo, copiou-se o modelo inglês 
posto em prática na Índia que garantiu poucos custos de dominação para os colonizadores que enfatizava a chamada "invenção das tradições", um modelo de cultural de "autoridade costumeira" para impor à África de modo a governá-la. O modelo consistia em descentralizar o governo das novas colônias utilizando-se de reis e chefias locais eleitos pelos colonizadores. As tribos e comunidades foram reestruturadas de modo que lhes era garantida alguma autonomia (não independência). Isto só foi possível dado que "o domínio europeu na África passou a ser definido por uma obstinada e imperiosa ênfase no consuetudinário" (Mamdani, 1996, p. 50).

O "despotismo descentralizado" foi, então, resultado de uma série de ações tomadas pelos europeus para garantir o controle das novas colônias sem ter de arcar com elevados custos da ocupação direta. Neste sentido, a dominação hegemônica só foi possível por meio de um projeto cultural "aproveitando o ímpeto moral, histórico e comunitário por trás dos costumes locais para um projeto colonial maior" (Mamdani, 1996, p. 286). Os europeus, desta forma, exerceram o poder de modo indireto, modificando as noções de cultura e do consuetudinário para dividir e governar e deram a elites locais que os apoiavam poderes alocativos e autoritativos (ainda que limitados). Elas foram responsáveis, em muitos casos, por conduzir o processo de independência das colônias africanas e tornaram-se os primeiros governos dos novos Estados africanos.

Tanto na corrente de "como se exerce o poder" quanto na corrente do "quem o exerce", as independências das colônias europeias na África não podem ser consideradas um retorno à história, pois não fizeram os Estados voltarem a ser endógenos às dinâmicas africanas. Como já dito, os novos Estados africanos (legado do colonialismo tardio) foram importados e tal processo representou-lhes apenas uma mera mudança de status e de liderança: antes colônias, agora independentes; antes com elites coloniais, agora com elites domésticas. Neste sentido, Englebert (2000b), chamou a atenção para o fato de que as independências não resolveram problemas criados pela colonização. Dentre eles, não se resolveu a questão da sobreposição de instituições pré e pós-coloniais. Isto é, muitas das fontes indígenas de autoridade e controle territorial não foram eliminadas nem neutralizadas pelos poderes coloniais e continuaram a existir e competir com as novas elites governantes. Este não foi um problema de "Tradição vs. Modernidade" nem de "Estado vs. Nação", mas sim de "instituições incompatíveis e conflitantes, soberania impugnada, e lealdade contestada" (Englebert, 2000b, p. 79). 
Tais fontes seguiram tão fortes que foram utilizadas diretamente ou tiveram alguns de seus métodos resgatados para resolver uma série de questões como justiça, governança, segurança e até reconstrução do Estado. Em Ogaden (região somali da Etiópia), os guurti (conselho de anciãos, em somali) foram reconhecidos e oficializados pelo governo etíope para aplicar o xeer (lei consuetudinária somali) e resolver conflitos locais (Hagmann, 2007); enquanto em Ruanda, o governo resgatou a ideia das gacacas (justiça sobre a grama, em quiniaruanda) para criar tribunais comunitários responsáveis por julgar os envolvidos no genocídio de 1994 que vitimou cerca de 800 mil pessoas (Clark, 2010) ${ }^{68}$. Em Burquina Faso, chefes tradicionais locais passaram a desempenhar papel importante e paradoxal na resolução da violência política desde o começo dos anos 2000, sendo vistos como acima de lealdades partidárias e interesses sectários, mas participando, ao mesmo tempo, dos partidos políticos (Hagberg, 2007). No Zimbábue, a Lei dos Líderes Tradicionais, sancionada em 1998, reconheceu e incorporou líderes tradicionais na política nacional em um contexto de crise econômica e política, e deu poder a tais atores para atuar junto de governos locais democraticamente eleitos o que aumentou consideravelmente a governança e a accountability das administrações locais (Mapedza, 2007). Na Somalilândia, os anciãos utilizaram-se do xeer não apenas para resolver conflitos locais como em Ogaden, mas para construir as bases institucionais do novo Estado, autodeclarado independente em 1991 e que tem conseguido se manter estável e funcional até os dias atuais (Menkhaus, 2006). De modo geral, as instituições tradicionais foram restauradas constitucionalmente ou se tornaram agentes de facto de governança e administração de bens públicos em vários outros lugares no continente como na África do Sul, Burquina Faso, Gana, Maláui, Moçambique, Namíbia, Nigéria, Uganda e Zâmbia. Não à toa, afirma-se que há uma onda de retradicionalização das instituições estatais na África Subsaariana (Ray \& van Nieuwaal, 1996; Englebert, 2002; Buur \& Kyed, 2007).

O que estes e vários outros casos demonstram é que a ideia da continuidade na política da África Subsaariana parece - neste momento - estar sobressaindo-se sobre a perspectiva de que a colonização refundou a política no continente. Isto quer dizer que mesmo com a substituição das elites e dos governos e a imposição de novas instituições políticas, a ideia de Estado (e principalmente, do Estado tradicional) não fora esquecida

\footnotetext{
${ }^{68}$ As gacacas julgaram indivíduos que foram acusados de tomar parte no genocídio, mas que não tinham grandes responsabilidades no processo. Utilizando-se de linguagem informal, elas jugaram os "peixes pequenos". Os "peixes grandes", isto é, os líderes e principais perpetradores do genocídio foram julgados pelo Tribunal Penal Internacional para Ruanda, instância ad hoc criada especialmente para esse caso.
} 
ou deixada de lado em momento algum. Ou seja, continuou presente no imaginário dos povos africanos a perspectiva de que há um ente responsável por controlar e pôr fim à violência - o que está entre as funções clássicas do Estado que almeja impor o monopólio do uso legítimo da força. Os movimentos de "retradicionalização" da política em vários Estados africanos podem até ter desempenhado, em alguns casos, papel importante em favor de ideais mais contemporâneos como a boa governança e a accountability. ${ }^{69}$ No geral, porém, todos eles favoreceram a instituição política básica e fundamental que é o Estado, pois fortaleceram sua autoridade.

Tanto os Estados hodiernos que passaram ou não por este processo quanto os Estados tradicionais africanos (e até mesmo os Estados enquanto eram colônias) lidaram com a questão da autoridade a partir de uma ótica semelhante uma vez que esta é, acima de tudo, condição sine qua non para o sucesso de toda e qualquer política pública. Tratase, portanto, de uma concepção de autoridade que leva em conta três características essenciais:1- a eficácia da governança, que compreende a capacidade de o Estado exigir o cumprimento de suas leis e a qualidade dos serviços públicos que o Estado se propõe a oferecer e sua independência com relação a pressões políticas; 2- a nomocracia, isto é, a ideia de que as ações do governo também são limitadas pelas leis; e 3- a ausência de violência política, ou seja, a baixa probabilidade de que o governo nacional seja deposto por meios violentos e inconstitucionais e de que a violência não será usada como meio de pressionar atores políticos.

\subsection{Exercício da autoridade estatal: funções e atores}

Estas características estão diretamente relacionadas com a manutenção de regras e da segurança e da ordem domésticas. Alguns exemplos bastante genéricos são capazes de ilustrar como elas são importantes na vida cotidiana da população e na estabilidade política dos Estados. Elas geram oportunidades e constrangimentos para várias ações assim como podem gerar descontentamentos e frustrações coletivas. Um Estado em que se ofereçam serviços públicos para apenas uma determinada parcela de sua população ou que dê flagrante prioridade para aliados políticos pode ter sua autoridade afetada negativamente. A nomeação para cargos no Estado de aliados e parentes e a ausência de concursos públicos para concorrer a eles geram descontentamento na população. Tal fato piora quando a possibilidade de concorrer a tais cargos ou de receber atendimento destes

\footnotetext{
${ }^{69}$ Relacionadas diretamente com duas das três instituições fundamentais nomeadas por Fukuyama (2011): o Estado de direito e o governo responsável.
} 
serviços seja condicionada à etnia, religião ou cor da pele dos indivíduos. Tal situação leva indivíduos preteridos a se organizarem para exigir - pacífica ou violentamente mudanças e extensão de direitos para toda a população. Foi o que ocorreu, por exemplo, com a Namíbia, com a Rodésia e com a África do Sul devido aos seus governos de segregação racial e, de certa forma, com todas as colônias na África.

Do mesmo modo, a capacidade em criar leis que sejam efetivamente vinculantes está diretamente ligada à autoridade Estatal. O objetivo de todo sistema legislativo é o de criar regras que possam ordenar minimamente a vida e as relações entre seus sujeitos. Para tanto, as mais variadas legislações criam oportunidades e constrangimentos para que os indivíduos as cumpram e comportem-se do modo estabelecido por elas. Aquele que seguir e obedecer à legislação poderá, por exemplo, exercer atividades permitidas como as de abrir um negócio, solicitar passaporte, viajar ao exterior etc. enquanto quem a descumprir sofrerá com sanções das mais diversas formas como multas, privações da liberdade e de outros direitos.

Por outro lado, quando o Estado não é capaz de exigir cumprimento às suas decisões e legislações, sua autoridade está comprometida e corrobora com a ideia hobbesiana de que pactos sem espadas são apenas palavras. É em momentos assim que surgem as oportunidades em violar a lei superam os constrangimentos. Um ladrão roubará pertences de um indivíduo comum na ausência de forças policias assim como a baixa capacidade de taxar produtos e defender os direitos intelectuais favorecerá o contrabando, a pirataria e a existência de comércio informal. É por estes motivos que as fronteiras porosas da grande maioria dos Estados da África Subsaariana são uma preocupação os EUA, que acreditam que por elas possam passar armamentos e suprimentos para grupos terroristas, e que a indústria cinematográfica da Nigéria que produz tantos - senão mais - filmes do que Bollywood, sua congênere indiana, tem dificuldades para obter rentabilidade e desenvolver-se ainda mais.

Por fim, nenhuma destas duas características pode ser alcançada em um Estado se nele houver a constante ameaça de que seu governo possa ser destituído de modo inconstitucional e se a política não encontrar outra expressão que não a violência. Quando grupos com interesses políticos (elites econômicas, militares etc.) passam a colocar em jogo a continuidade do governo no poder ignorando as regras estabelecidas, o Estado talvez tenha chegado aos mínimos níveis de autoridade. Por mais que seja verdade que 
em muitos casos a troca de governo por meios violentos e não constitucionais não represente a refundação do Estado, ela representa o questionamento completo de todas as suas instituições. Não é à toa que, geralmente, quando ocorre um golpe de Estado, aqueles indivíduos que podem juntam a família e alguns pertences e tentam escapar do país. Além da possibilidade de eclosão de uma guerra civil quando o golpe fracassa ou quando o governo deposto tenta voltar ao poder pelos mesmos meios que o retiraram de lá, há uma volta à anarquia ou, na melhor das hipóteses, a instauração de um estado de exceção. Desta forma, mesmo quando um golpe de Estado tem lugar e não é seguido de guerra civil, o novo governo tem o dever de recuperar a autoridade das instituições que ele mesmo tornou desacreditadas ou substituí-las.

Não se trata, contudo, de abrir o debate sobre a relação de democracia e autoritarismo com a autoridade estatal. Apesar de muitos dos índices que visam medir a falência dos Estados levarem em consideração o caráter democrático ou não dos regimes e classificarem aqueles não democráticos de modo mais próximo da falência, não se pode insistir nesta relação quando estiverem sob avaliação os Estados da África Subsaariana. Casos como o de Madagascar e da Nigéria indicam neste sentido. No primeiro caso, os relativamente altos níveis de autoridade de que o país gozava durante a primeira década dos anos 2000 não foram suficientes para impedir que o governo de Marc Ravalomanana, eleito em 2006, fosse dissolvido três anos depois por uma revolta militar liderada pelo então prefeito da capital de Antananarivo, Andry Rajoelina. No segundo caso, mesmo em meio ao turbilhão causado pelos ataques do grupo extremista Boko Haram, a Nigéria conseguiu realizar eleições presidenciais sem maiores problemas e eleger o candidato oposicionista, Muhammadu Buhari.

Neste sentido, além de o autoritarismo poder ser visto como uma forma de exercer a autoridade e como um mecanismo para neutralizar e eliminar fontes concorrentes de autoridade, os regimes autoritários na África Subsaariana também parecem ter profunda responsabilidade, paradoxalmente, no sucesso da institucionalização da democracia em seus países. A trajetória de países como Gana, Senegal, Zâmbia e Benim indicou que os primeiros estágios da abertura democrática ofereceram, na verdade, oportunidades para que os líderes autoritários moldassem o novo sistema multipartidário de acordo com seus próprios interesses. Nos países em que os líderes autoritários eram fortes e tinham o apoio necessário, eles conseguiram controlar o processo de transição e assim permitiram uma maior institucionalização do sistema partidário no novo regime democrático. Por outro 
lado, onde estes eram fracos e não gozavam do apoio necessário, eles não tiveram o controle da agenda da transição e assim os novos atores contribuíram de descoordenadamente para o processo, o que prejudicou a institucionalização do novo sistema (Riedl, 2014).

Portanto, é a partir destas características que se pode afirmar que a construção da autoridade estatal está diretamente ligada à construção do Estado. A eficácia da governança, a nomocracia e a ausência de violência política e terrorismo resumem as funções mais básicas e clássicas dos Estados de forma geral e universal assim como são a base para que perspectivas mais modernas sobre o Estado (como o Estado de direito e o governo responsável) ocorram. É difícil pensar numa polity na África Subsaariana ou fora dela que não as tenha tido como objetivo para garantir sua sobrevivência. É a partir desta análise minimalista sobre os Estados na África Subsaariana que se permite fazer uma avaliação deles e de seu desempenho baseada na longa duração e que os compare aos Estados de outros lugares do mundo.

Como se vê, a questão em debate aborda a capacidade que os Estados na África Subsaariana têm em desempenhar as funções básicas inerentes aos Estados. Garantir a segurança e a ordem internas e a existência externa têm sido a preocupação de todos os Estados da região, tradicionais ou pós-coloniais. O próprio fato de guerras interestatais serem bastante raras entre os Estados hodiernos da região é, na verdade, consequência não só do padrão de difusão do poder que torna extremamente custoso um conflito nas áreas mais remotas do Estado, mas também de uma série de medidas que trataram de santificar as fronteiras (Touval, 1972; Herbst, 2000). Ademais, a garantia da segurança e ordem internas é a melhor expressão da capacidade de governar a sociedade que um Estado tem. Afinal, seguindo Huntington (1968), a principal distinção que se pode fazer entre os Estados não é sobre o tipo de governo que eles têm, mas sim sobre grau em que realmente são capazes de governar e exercer suas funções mais básicas. É por isso que a autoridade estatal parece estar no centro das questões quando se trata do desempenho dos Estados africanos e por isso pode-se dizer que "o maior problema não é que haja muita autoridade, mas pouca" (Zolberg, 1969, p. x). Dentro desta discussão, Carment, Prest e Samy (2010, p. 111) apresentaram evidências bastaste fortes que lhes permitiram afirmar que há "uma relação significante entre eventos de falência estatal e mudanças de curto prazo na autoridade e, sob certas circunstâncias, na legitimidade". 
Uma das características bastante marcantes sobre os Estados falidos na África Subsaariana talvez seja a de que o governo central não consegue ou não quer governar sobre todo seu território. Vácuos de poder em áreas remotas e distantes do centro político e econômico do Estado são, supostamente, áreas onde poderes paralelos e atividades criminais ocorrem com maior frequência pois não há o medo de sofrer sanções oriundas do Estado. Esta característica especificamente é bastante clara quando se avalia os Estados com maior extensão territorial como os "Grandes Estados Africanos", já citados anteriormente. Contudo, também em Estados menores tal característica pode ser encontrada. Assim, uma forma de avaliar a autoridade estatal é por meio da implementação das políticas e regras impostas pelo governo central nas áreas mais remotas do Estado.

A falha de um Estado em propagar sua autoridade para além do centro político pode ser devida a fatores que envolvem sua capacidade e, até mesmo, sua vontade em fazê-lo. No que tange à capacidade, pode-se afirmar que faltam aos Estados os recursos necessários para fazer-se presente em tais regiões. Quanto à falta de vontade, o já mencionado retorno decrescente em escala explica o porquê de muitos Estados na África Subsaariana (principalmente os maiores) não investirem e não se mostrarem presentes em áreas mais distantes da capital. Ou o Estado realmente não os possui ou então seus agentes executam o cálculo sobre os possíveis retornos e decidem então aplicá-los em outras regiões. Não é à toa, por exemplo, que a região de Ogaden, na Etiópia, e do Darfur e a que correspondia ao Sudão do Sul antes da secessão em 2011, no Sudão, são as regiões com menor presença de seus respectivos Estados e que, no caso sudanês, os conflitos domésticos começaram a surgir, principalmente no Darfur, após a descoberta de petróleo na região, o que alterou o resultado do cálculo feito por Cartum sobre os custos e retornos da difusão do poder sobre a região.

Outro fator que impede que os Estados implementem suas políticas e fazerem-se presente em seus rincões mais distantes é que, devido à dificuldade e à falta de capacidade em fazê-lo, pode haver nesses lugares fontes concorrentes de autoridade. Neste sentido, eles evidentemente falharam em constituir-se como única autoridade no território que pretendem governar. Isto é, não são os únicos provedores de justiça e também não detêm o monopólio do uso legítimo da violência. As populações nessas regiões acabam sendo sujeitas a mais de uma fonte de autoridade. A grande questão é a qual elas efetivamente obedecem. Os casos em que houve a "retradicionalização" da autoridade ilustram 
especificamente esta realidade. O reconhecimento por parte do Estado etíope dos guurti em Ogaden demonstra este ponto. Além disso, grupos armados que reivindicam maior autonomia ou até mesmo a secessão de determinadas regiões dentro dos Estados também ilustram tal fato. Em 2012, por exemplo, foi necessária que o governo do Mali solicitasse uma intervenção militar francesa para que pudesse ter maior controle sobre a região do Azauade, onde o Movimento Nacional de Libertação do Azauade (MNLA) havia praticamente conquistado o monopólio da coerção. Além destes, a atuação da União das Cortes Islâmicas (UCI) na Somália entre 2006 e 2009, quando controlou a capital e o sul do país a despeito da existência do Governo Federal Transitório no país, foi também um claro exemplo de uma fonte de autoridade paralela ao Estado.

Estes casos demonstram que a luta pela autoridade e para decidir quem faz as regras vai além do uso da violência e não se resolve simplesmente com a força e que outros incentivos são necessários para fazer as pessoas obedecerem às regras independentemente de quem as tenha feito. O caso da Somália é bastante interessante neste sentido. O longo período sem a presença de um governo central no país fez com que surgissem sistemas informais, porém mais orgânicos de segurança e governança, liderados por grupos empresariais, autoridades tradicionais etc. Enquanto alguns espoliadores conseguiram perturbar o processo de paz e encontram vantagens em perpetuar o conflito armado e o estado de anarquia, outros trabalharam em prol da construção da paz e da redução da criminalidade. Este tipo de processo não é particular da Somália. No geral, comunidades que ficaram de fora da autoridade estatal "procuram elaborar arranjos para fornecerem-se as funções essenciais que o Estado deve assumir, especialmente a segurança básica" (Menkhaus, 2006, p. 75). Também na província de Ituri, na República Democrática do Congo, a Segunda Guerra do Congo devastou o tecido social local e criou, paradoxalmente, "uma plataforma perfeita para atores políticos e econômicos locais redefinirem suas posições neste novo cenário político e econômico", uma vez que o próprio governo não podia dedicar-lhe atenção dado que o próprio estava para ser derrubado (Vlassenroot \& Raeymaekers, 2004, p. 385).

A autoridade do Estado e de outros atores, portanto, apresenta duas faces complementares e que são essenciais para que imponha regras e se exija o cumprimento das mesmas. O que os casos anteriores demonstraram é que a autoridade pode ser identificada tanto pelo seu lado tangível (recursos) quanto pelo intangível (percepção). No primeiro caso, o Estado (ou atores que detém graus de estatalidade) devem ter os 
recursos para criar regras e punir aqueles que não as cumpram. No geral, esses recursos estão diretamente ligados com a coerção e com a coação. $\mathrm{O}$ ator que pretende impor sua vontade tem como sua ultima ratio o uso da força física. Neste sentido, o descumprimento da lei é punido com medidas que variam desde meras advertências até a pena capital, passando pela aplicação de multas e privação de liberdades. Onde o Estado detiver o monopólio do uso destes recursos, ele será soberano.

O problema reside, contudo, no fato de que muitos Estados não têm recursos suficientes para impor sua autoridade e fazer valer suas leis e políticas em partes do próprio território. Neste caso, a autoridade estatal pode ser completada pela percepção que a população e outros atores têm dela. Voltando ao exemplo que afirmava que um ladrão roubará os pertences de um indivíduo comum na ausência de forças policiais, ele também o fará na presença das mesmas se julgar que estas não lhe deterão ou tentarão impedi-lo. Do mesmo modo, de nada adiantará o policial ter os recursos para pará-lo (armas) se não souber manejá-los. Seguindo esta lógica, um grupo guerrilheiro pegará em armas e começará a impor suas regras e vontades em determinada parte do território ou até mesmo desafiará o governo central se entender que este tem menos poder efetivo do que ele e, consequentemente, menores chances de derrotá-lo.

É por isso que os Estados na África Subsaariana e no resto do mundo buscaram aumentar a capilaridade de sua autoridade e trataram de criar instituições e órgãos estatais capazes de aplicar sanções e espalharam-nos por todo o território. Ainda que isto não modifique os retornos decrescentes em escala, é importante salientar que o Estado assim se faz presente em seu território, dando novos contornos e determinantes para os conflitos locais: os grupos beligerantes que lutaram pela secessão geralmente estavam mais interessados em controlar as instituições estatais do que efetivamente separar-se. Este seria o caso do conflito de Casamança, Senegal, das revoltas tuaregues no Níger e no Mali e da longa guerra perpetrada pelo Sudão do Sul contra Cartum. Uma vez que os Estados são dotados de "comando legal", que lhes autoriza a retirar a renda da população sem que esta seja capaz de sancioná-los, sua resiliência pode ser explicada pelo interesse de parte das elites em manter suas rendas e sinecuras garantidas indiretamente pelo sistema internacional. É por isso que em lugares como Baroce, na Zâmbia; as províncias Kivu, na República Democrática do Congo; e nas áreas anglófonas de Camarões, os escritórios dos organismos estatais continuam funcionando mesmo que não sejam capazes de exercer efetivamente suas funções (Englebert, 2009). 
A disputa pela autoridade nos Estados da África Subsaariana destaca, assim, seu componente intangível. Além da questão pela posse de instituições que não funcionam, é preciso ressaltar que o Estado costuma disputar a autoridade com fontes que não tem nada de tangível para oferecer como líderes religiosos e figuras de referência na sociedade, como os anciãos na Somália, por exemplo. Os casos em que Estados africanos reconheceram e incorporaram os líderes tradicionais demonstram, na verdade, quão frágil é a sua autoridade e como a relação entre as autoridades estatal e tradicional pode ser de alinhamento ou concorrência. Do mesmo modo, o uso das instituições públicas para fins privados prejudica a própria ideia de capilaridade do poder estatal e não oferece nenhuma resistência aos "Estados-sombra" que, segundo Reno (1993), é um sistema de domínio pessoal construído normalmente por trás da fachada de um Estado formal e fundado sobre o controle de mercados de modo a manipular o aceso aos recursos daí oriundos. $\mathrm{O}$ problema é que os atores que se beneficiam diretamente dele muitas vezes também controlam os meios de coerção, necessários tanto para manter a obediência quanto para depor o próprio governante. Não bastasse o "Estado sombra" comprometer tanto a nomocracia quanto a eficácia da governança, o fato de aqueles que o controlam deterem recursos que podem tanto favorecer quanto depor o governante abre espaço para mudanças inconstitucionais de governo e para o uso de violência como ferramenta política. Em suma, o Estado sombra age prejudicialmente em todos os componentes da autoridade estatal.

\subsection{Considerações finais}

Como já foi dito, esta concepção sobre autoridade estatal vale para todas as polities que se assemelham a Estados, inclusive na África Subsaariana desde seus tempos tradicionais até os hodiernos. É com base nela que se buscou demonstrar neste capítulo que os conflitos intraestatais na África Subsaariana estão diretamente ligadas às mudanças nos níveis de autoridade dos Estados. Mesmo nos casos de Ruanda e Libéria, em que a autoridade estava parecia estar diretamente relacionada com o desenvolvimento dos Estados, procurou-se demonstrar que a alta correlação entre as duas variáveis não se refletiu em causalidade e que, se não fosse pelas crises de autoridade ocorridas naqueles Estados, é bem provável que o conflito não tivesse eclodido. Na próxima parte deste estudo, será demonstrado como a variação nos níveis e nos fatores que incidem na composição da autoridade estatal influenciam na manutenção da paz ou na ocorrência da guerra. 


\section{Parte II - Os caminhos para a paz e para o conflito}

Na primeira parte deste trabalho, buscou-se realizar uma avaliação não apenas da literatura sobre o vínculo entre subdesenvolvimento e eclosão de conflitos, mas também questionar a relação causal entre eles. A esta altura, o leitor deve ter percebido - e quiçá se incomodado com - o fato de este volume defender uma visão mais estruturalista sobre o surgimento de conflitos na África Subsaariana. Por mais que se reconheçam os males sociais que o subdesenvolvimento pode causar, é importante destacar que alegar sua causalidade com a eclosão de conflitos intraestatais é, na verdade, tornar absolutas suas consequências. Como foi dito, se por um lado é verdade que as guerras civis vêm de longa data se concentrando em países subdesenvolvidos, é igualmente verdadeiro que muitos destes têm a guerra como uma exceção em sua história e que alguns deles inclusive tiveram a paz como regra em sua política doméstica desde sua independência.

Além disso, esta parte deste estudo pretende mostrar - acima de tudo - que as coisas mudam. Ao contrário do que o imaginário popular e midiático (e de alguns acadêmicos também) alega, os países na África Subsaariana têm política dinâmica e são capazes de se recuperar dos conflitos pelos quais passaram. Em 2006, por exemplo, o número de conflitos havia caído pela metade e a quantidade de baixas havia sido reduzida em $98 \%$ após atingir o pico em 1999 de acordo com o Human Security Brief (2007). Além disso, é digno de nota que diferentes bancos de dados tendem a concordar entre si quando se trata de tendências sobre os conflitos africanos. Como um autor destacou, os dados do Political Instability Task Force, do Monty Marshall e do Uppsala Conflict Data Programme apontam (mesmo que com metodologias distintas e números diferentes) que os anos 1980 foram particularmente sangrentos no continente e que houve, nas décadas seguintes, uma importante redução no número de conflitos armados no continente (Williams P. D., 2011).

Outro dado importante de ser ressaltado é que boa parte da África tem permanecido alheia às dinâmicas de violência e conflitos intra e interestatais. Não à toa, um importante centro de pesquisas para a paz declarou 10 países na região como “zonas de paz", por não terem sucumbido a tais dinâmicas (Stockholm International Peace Research Institute, 
2016).$^{70}$ Isto não apenas reforça a ideia da heterogeneidade entre os países africanos como também abre espaço para uma nova indagação: se há zonas de paz no continente, será possível a existência de zonas onde a guerra e a violência sejam endêmicas? A resposta parece ser positiva. Se por um lado isto é uma má notícia uma vez que há lugares em que não se consegue quebrar tal ciclo, por outro, isto é uma boa notícia uma vez que indica um número cada vez mais diminuto de países com conflitos internos na África (e no mundo todo). Foi neste sentido que um relatório do Banco Mundial chamou a atenção para o fato de que enquanto no número total de guerras vinha diminuindo desde os anos 1960, sua concentração em países com passado de guerra civil e violência aumentava: entre os anos de 2000 e 2010, 90\% das guerras aconteceram em países que já haviam sido palco de conflitos nos dez anos anteriores (World Bank, 2011). No caso africano, países como a Burundi, República Centro-Africana e República Democrática do Congo são exemplos que ilustram estes ciclos repetidos de violência. Tal concentração dos conflitos em um número cada vez mais reduzido de países é revelada também na quantidade de mortes que os conflitos têm produzido. Em 2014, apenas 9 países foram responsáveis por $92 \%$ das mortes em conflitos em todo o continente africano (Cilliers, 2015). ${ }^{71}$ Isto não só demonstra que a guerra não é um problema generalizado e endêmico no continente, mas também permite relativizar a gravidade das guerras existentes uma vez que chegam a ser menos violentas que a realidade dos crimes em países ditos em paz. ${ }^{72}$

Estes dados que inauguram a segunda parte deste estudo são relevantes pois cumprem dois propósitos. Primeiro, ajudam a desconstruir uma imagem monolítica do continente que, ao destacar os conflitos e outras mazelas, acabam fazendo-o de forma generalizante. Segundo, auxiliam ao leitor a compreender a real dimensão do problema em questão na África Subsaariana. Destarte, compreende-se que análises mais corretas e rigorosas bem como uma formulação de políticas mais justa e adequada às realidades e necessidades dos países da África Subsaariana são possibilitadas quando se possui tais dados em mãos. Longe de aderir à lógica de "cada caso é um caso", este estudo destaca que tal heterogeneidade é consequência da variação dos estados em um mesmo eixo, o que

\footnotetext{
${ }^{70}$ Benim, Botsuana, Cabo Verde, Guiné Equatorial, Maláui, Maurício, São Tomé e Príncipe, Seychelles, Suazilândia e Zâmbia.

${ }^{71}$ Em ordem decrescente do número de mortes: Nigéria, Sudão do Sul, Somália, Sudão, República CentroAfricana, Líbia, Egito, Camarões e República Democrática do Congo.

72 Segundo o Mapa da Violência, relatório anual produzido pelo sociólogo Julio Jacobo Waiselfisz, a taxa de homicídios para cada 100 mil habitantes no Brasil em 2014 foi de 25,86. Em comparação com os países que mais concentraram mortes por conflitos na África, o país teria ficado atrás apenas de República CentroAfricana, Sudão do Sul, Líbia e Somália no mesmo ano.
} 
permite análises generalizantes mais parcimoniosas e científicas e menos preconceituosas.

Na parte anterior, foram feitas menções a casos e dinâmicas de nove países da África Subsaariana (África do Sul, Angola, Costa do Marfim, Etiópia, Libéria, Mali, Ruanda, Somália e Zimbábue). A maior parte destes será retomada nesta parte uma vez que aqui proceder-se-á com análise baseada na sistematização dos países da região separados de acordo com o nível de desenvolvimento e a ocorrência de conflitos intraestatais e falência de Estado em sua história. Deste modo, esta segunda parte analisará vinte e cinco Estados da região. República Centro-Africana, Comores, Costa do Marfim, Gana, Guiné, Quênia, Madagascar e Níger serão privados de análise mais profunda nesta seção uma vez que tiveram conflitos não-estatais, mas não tiveram guerras civis em sua história. Esta decisão não afeta os resultados e as conclusões desta pesquisa. Apesar de os conflitos não-estatais também terem maior ocorrência em locais onde a autoridade estatal é mais fraca e por muitas vezes estarem relacionados com os processos políticos em países frágeis, eles não chegam a desafiar a própria existência do Estado. Mesmo assim, os achados desta pesquisa - insiste-se - são válidos para estes países também.

Neste trabalho, a classificação feita dos países entre aqueles que nunca passaram por guerras civis ou conflitos não-estatais foi feita da seguinte forma: primeiro, se o país nunca passou por nenhum conflito armado intraestatal é classificado como pacífico; segundo, caso tenha passado por algum, será considerado como guerra-civil se tiver vitimado fatalmente mais de 1000 pessoas em um ano-calendário ou durante o período ininterrupto em que o conflito ocorreu; terceiro, a simples ocorrência de um conflito nãoestatal desde sua independência (independentemente da duração, quantidade de partes envolvidas ou número de mortes) impede de categorizar o Estado como pacífico. A separação entre conflitos intraestatais (guerra civil) e conflitos não-estatais deve-se sobretudo a dois fatores: a natureza dos combatentes e ao número de mortos por anocalendário ou duração do conflito. Enquanto nas guerras intraestatais há grupos organizados que se opõem ao governo do país e tem como objetivo tomá-lo de assalto ou secessão, os conflitos não-estatais envolvem grupos menos organizados (e às vezes sem nenhuma organização hierárquica) e não têm como objetivo assaltar as instituições estatais. No que tange ao número de mortos, os oito países que tiveram conflitos nãoestatais (ver tabela 1) tiveram sensivelmente menos baixas do que os países que tiveram conflitos intraestatais. Como a maioria dos conflitos não-estatais aconteceram após 
manifestações políticas (devido a denúncias de fraude eleitoral como no Quênia em 2008 e a apoiadores de político deposto como em Madagascar em 2009), a onda de violência acabou servindo apenas como uma forma de protesto e apoio dos envolvidos. ${ }^{73}$

As figuras 2 e 3 oferecem fluxogramas que guiam estes questionamentos. Todos os países que, ao fim deles, chegarem à expressão pacífico são aqueles classificados como pacíficos, isto é, são os que nunca passaram por guerra civil ou conflitos não-estatais desde sua independência. Por outro lado, aqueles que chegarem à expressão não-pacífico são aqueles que tiveram guerra civil, conflitos menores cuja duração causou o mesmo número de mortes que uma guerra civil ou conflitos não-estatais. Para fins de classificação neste estudo, o país deve ter atingido o resultado pacífico em ambos fluxogramas para serem considerados como tal.

A grande quantidade de países que nunca passaram por guerra civil ou conflitos nãoestatais após a independência demonstra um quadro interessante. Ao contrário do que um senso comum (fomentado pela mídia em boa parte) de que o continente todo é palco constante de guerras e barbáries, a parcela dos países pacíficos na África Subsaariana após a independência ultrapassa os $40 \%$. Mesmo assim, boa parte dos estudos em segurança da região preferiram focar-se nos países que passaram por processos de falência estatal e onde a instabilidade reinou por algum (senão todo) o período após as independências. Um dos motivos para isso é que talvez seja muito mais fácil identificar variáveis que causem a guerra do que a paz e que pensar a paz e suas causas como a negação da guerra e suas causas é um exercício longe de ser consensual. Mesmo assim, este trabalho considera que paz e guerra são extremos de um mesmo continuum e por isso podem ser trabalhados como a negação um do outro. A grande questão é que muito da literatura apontou para aquelas que não são as causas do conflito. Além do subdesenvolvimento per se, muito da literatura apontou para a questão da má vizinhança; os regimes políticos que não são nem democracias bem estabelecidas ou ditaduras estáveis; a questão étnica; e a abundância de recursos naturais (Hegre \& Sambanis, 2006). Estes fatores estão, no geral, ligados à capacidade e vontade dos indivíduos de agirem (agência) e, talvez pela fraqueza endêmica dos Estados que passaram por processos de falência, as análises que os consideram como causas dos conflitos na África Subsaariana

\footnotetext{
${ }^{73}$ Apenas Gana teria atingido o critério do número de mortos por ano-calendário ou duração do conflito. Em 1994, membros dos grupos étnicos Dagomba, Gonja e Namumba enfrentaram o Konkomba, vitimando 2004 pessoas por questões comerciais (Uppsala Conflict Data Program, 2016).
} 
praticamente desconsideram os constrangimentos que o Estado pode impor à ação que leve à guerra (estrutura).

Figura 2 - Classificação de país com ou sem conflito com relação a conflitos intraestatais

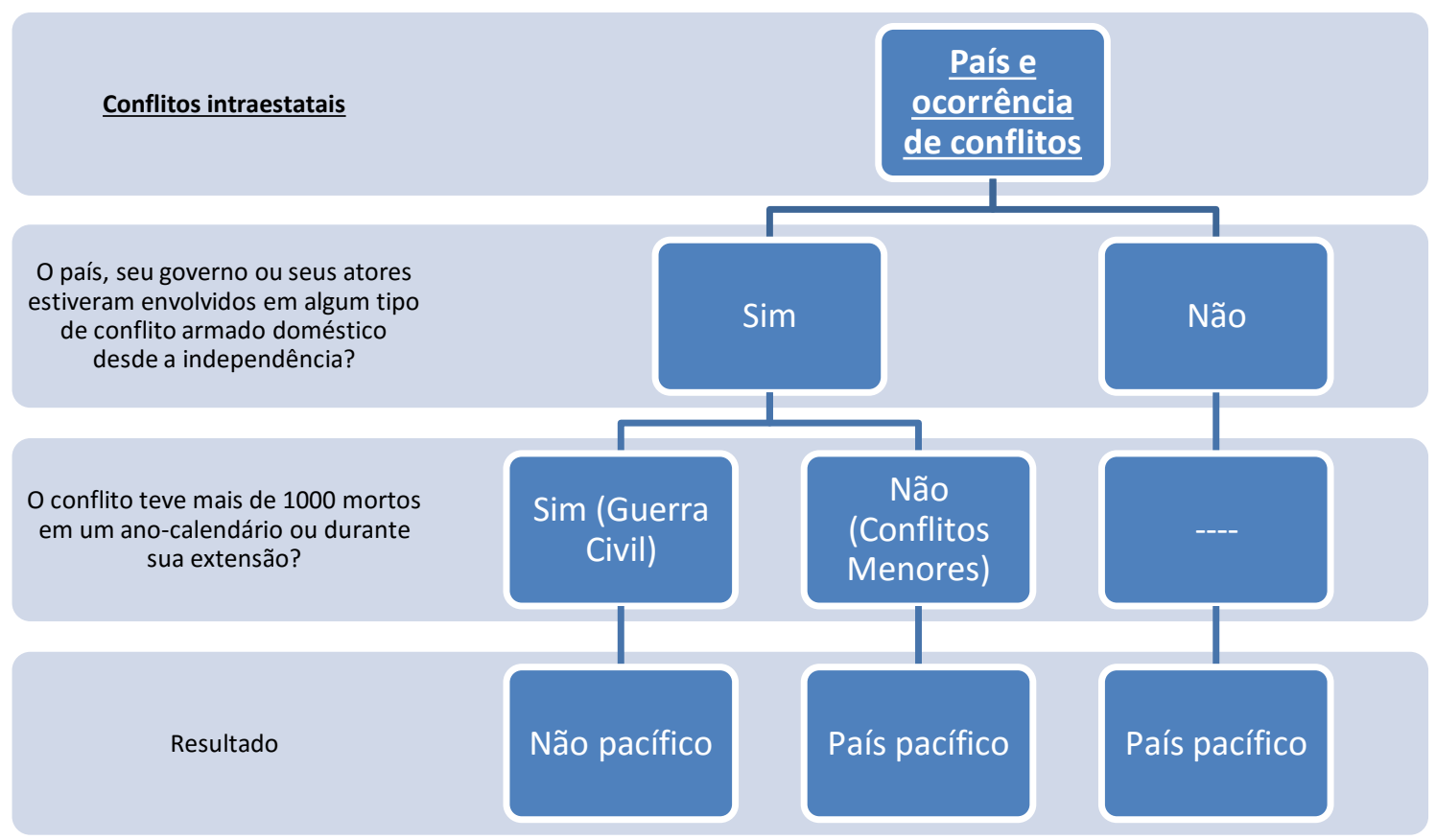

Figura 3 - Classificação de país com ou sem conflito com relação a conflitos não-estatais

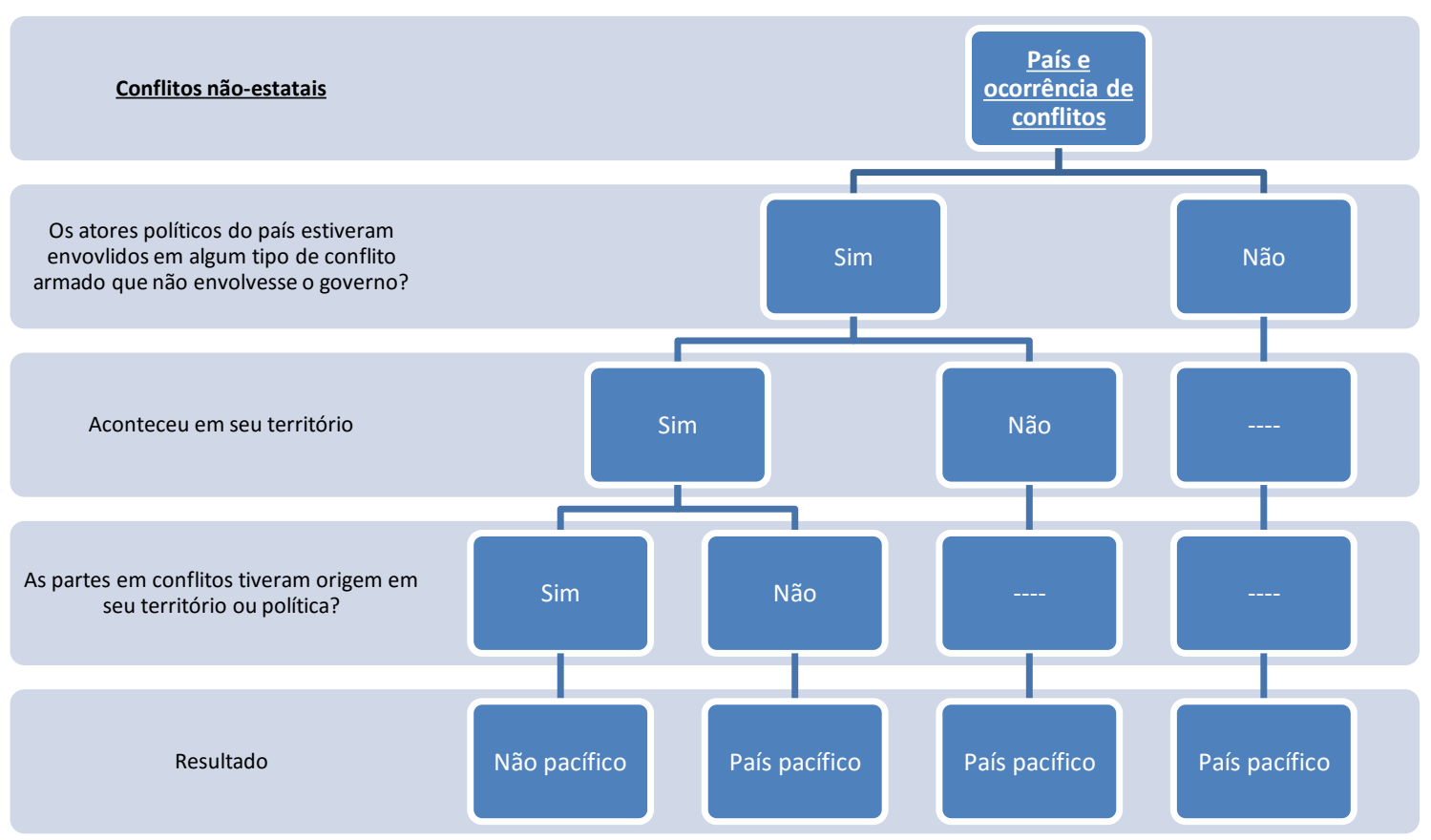


Tabela 1- Lista de países conforme a ocorrência de guerra civil ou conflitos não-estatais em sua história independente

\begin{tabular}{|c|c|c|}
\hline $\begin{array}{l}\text { Sem guerra civil ou } \\
\text { conflitos não-estatais }\end{array}$ & Com guerra civil & $\begin{array}{l}\text { Com conflitos não- } \\
\text { estatais }\end{array}$ \\
\hline Benim* & África do Sul* & Rep. Centro-Africana \\
\hline Botsuana* & Angola & Comores \\
\hline Burquina Faso* & Burundi & Costa do Marfim \\
\hline Cabo Verde* & Camarões* & Gana \\
\hline Djibuti & Chade & Guiné \\
\hline Eritreia & Congo-Brazzaville & Quênia \\
\hline Gabão* & Congo-Kinshasa & Madagascar \\
\hline Gâmbia* & Etiópia & Níger \\
\hline Guiné-Bissau & Libéria & \\
\hline Guiné Equatorial* & Mali & \\
\hline Lesoto & Mauritânia & \\
\hline Maláui* & Moçambique & \\
\hline Maurício* & Nigéria & \\
\hline Namíbia* & Ruanda & \\
\hline São Tomé e Príncipe* & Senegal & \\
\hline Seicheles* & Serra Leoa & \\
\hline Suazilândia* & Somália & \\
\hline Tanzânia* & Sudão & \\
\hline Togo* & Sudão do Sul & \\
\hline Zâmbia* & Uganda & \\
\hline \multicolumn{3}{|l|}{ Zimbábue* } \\
\hline 21 países & 20 países & 8 países \\
\hline
\end{tabular}

Como será apresentado nos próximos capítulos a autoridade estatal - composta pela ausência de violência política e terrorismo, eficácia da governança e nomocracia encontra suas fundações na geografia política, isto é, na combinação do tamanho do território com a distribuição da população sobre ele; na legitimidade vertical, isto é, no consenso da população sobre as instituições estatais que a governa; na cultura política do país, que revela que a população tem ou não predisposição a obedecer o governo seja ele qual for; no papel dos líderes tradicionais, que podem agir como fontes concorrentes de autoridade e assim desafiar o Estado; e nas regras costumeiras, que se impõem sobre a população principalmente em questões sensíveis como a posse da terra. No caso dos quatro países analisados no quinto capítulo, notar-se-á que nenhum ou quase nenhum desses fatores estavam presentes quando tais Estados sucumbiram à guerra civil. Deles, apenas Libéria e Ruanda tinham geografia política favorável à projeção do poder e consolidação da autoridade estatal e apenas o segundo tinha legitimidade vertical. Isso é 
um motivo pelo qual, como se verá, a reconstrução pós-conflito desses países baseou-se primordialmente em uma concepção de autoridade estatal baseada em instituições semelhantes às ocidentais.

Além disso, esta segunda parte mostrará mais a fundo como o papel da continuidade das civilizações e do tamanho do território facilitam a consolidação da autoridade estatal e, consequentemente, diminuem a probabilidade de conflito intraestatal e do processo de falência do Estado. Como se verá, a semelhança dos Estados tradicionais que estavam presentes nos territórios dos atuais Estados pós-coloniais que não passaram por guerra civil ou conflitos não-estatais era maior do que naqueles que tiveram tais fenômenos. ${ }^{74} \mathrm{O}$ tamanho pequeno do território dos Estados atuais também é documento neste sentido: os Estados que nunca tiveram guerra civil ou conflitos não-estatais durante sua história independente estão em sua maioria nos dois primeiros quartis (até o $25^{\circ}$ e até o $50^{\circ}$ percentil) do tamanho dos territórios dos Estados da África Subsaariana. ${ }^{75}$

\footnotetext{
${ }^{74}$ A diferença da média dos dois grupos é significante para $99 \%$ de confiança.

${ }^{75}$ Excluindo-se os países insulares, sete países do primeiro quartil e cinco do segundo eram pacíficos. Somando-se os países insulares e os continentais, nove países do primeiro quartil e seis do segundo eram pacíficos. Apenas com os países continentais, cada um dos quatro quartis eram compostos por onze Estados. Considerando-se todos os países, esse número sobe para doze.
} 


\section{Contra as probabilidades: a paz nos países menos desenvolvidos}

Como já se disse exaustivamente neste estudo, seu argumento central é de que o subdesenvolvimento não é a causa dos conflitos intraestatais e da falência dos Estados africanos. Conforme foi exposto na introdução, os países menos desenvolvidos do mundo deveriam ter conflitos domésticos segundo as perspectivas que unem desenvolvimento e segurança. No entanto, este cenário não se fez verdadeiro. No início, mencionou-se um grupo de países que jamais passou por uma guerra civil desde a independência, mas em uma nota de rodapé afirmou-se que alguns deles poderiam ter sim passado por episódios de violência política. Mesmo assim, há outros seis países na África Subsaariana que, além de jamais terem tido guerra civil, também nunca passaram por episódios de violência política (conflitos menores). Pois bem, este capítulo tem como objetivo analisar justamente este grupo de treze países que contrariam a tese que vincula segurança e desenvolvimento e demonstrar como a estrutura estatal evitou a formação de guerras civis, mesmo diante de abruptas rupturas da ordem política e legal, em um cenário de extremo subdesenvolvimento.

Primeiramente, é necessário reforçar que as definições que compõem a categoria dos PMDs são interdisciplinares e tratam o desenvolvimento como algo multidimensional. Isto é, não se trata apenas de tamanho ou crescimento do PIB e do PIB per capita. Tratase de uma abordagem que leva em conta obviamente a renda bruta per capita do país, mas também leva em conta (e com igual peso) os recursos humanos disponíveis no país (nutrição da população, saúde e educação) e também a vulnerabilidade econômica de sua economia (choques externos, dependência de exportações, tamanho da população etc.). Esta abordagem utilizada pela ONU para medir e classificar os Estados como PMDs compreende as metas e alvos estabelecidos na Declaração do Milênio, que estabeleceu os ODMs mas que ainda reconhecia o vínculo entre segurança e desenvolvimento.

Segundo, é importante destacar que os PMDs são um grupo bastante representativo da realidade africana e que esses treze países alvo deste estudo constituem importante parcela deles. Dos 48 PMDs do mundo, 34 ficam na África Subsaariana. Isto é, eles representam quase $70 \%$ de toda a sub-região. Além disso, treze deles nunca tiveram guerra civil ou conflitos não-estatais desde a independência e destes, seis nunca tiveram nem mesmo conflitos menores desde sua emancipação. Ou seja, este espaço amostral 
engloba praticamente 38,2\% dos PMDs na África Subsaariana (ou 26,5\% do total de países na região) e impressiona o tempo em que tais estados estão nessa nada honrosa categoria: seis deles estão lá desde 1971 - quando a categoria foi criada - e outros pioraram seus índices de desenvolvimento de tal modo que foram incluídos na lista. ${ }^{76}$

Terceiro, e por fim, chama a atenção a heterogeneidade existente entre esses países, o que dificulta ainda mais classificá-los como meramente excepcionais. No tocante ao tamanho do território, a Tanzânia (maior deste grupo) tem um território 982 vezes maior que o de São Tomé e Príncipe (menor deste grupo) e 84 vezes maior que o da Gâmbia (menor país de território continental do grupo). Ela também tem a maior população do grupo (52 milhões de habitantes), 265 vezes maior que o de São Tomé e Príncipe (país menos populoso do grupo) e 69 vezes maior que a da Gâmbia (país continental menos populoso do grupo). ${ }^{77}$ Além disso, também o histórico colonial apresenta proporções semelhantes à do resto do continente. Destes treze países em questão, cinco foram colonizados pelo Reino Unido, quatro pela França, dois por Portugal, um pela Espanha e um que era possessão da Etiópia.

Diante deste quadro, a história de paz deste seleto grupo de países precisa ser investigada com profundidade na esperança de que suas experiências possam servir de inspiração a policymakers na tentativa de pôr fim às guerras que estão em andamento em outros países e, principalmente, de evitar a eclosão de novos conflitos. Como se vê, não foi por causa do desenvolvimento que estes países lograram viver sem passar pela experiência da guerra civil, uma vez que esteve ausente durante suas histórias enquanto países independentes. Também fica difícil explicar se forem tomados como base em outros quatro fatores aos quais geralmente se atribui a eclosão de guerras civis e falência estatal: má vizinhança, regime político, etnias e recursos naturais.

\subsection{Avaliando a causalidade convencional}

Primeiro, a questão da má vizinhança não parece ser suficiente para fazer com que estes países sucumbam a guerras civis ou que tenham guerras não-estatais, tal como mostra a Figura 3. Os treze PMDs que nunca passaram por guerra civil ou abrigaram conflitos não-estatais estão cercados de países vizinhos que sim passaram pela

\footnotetext{
${ }^{76}$ Gâmbia, 1975; Guiné-Bissau, 1981; Djibuti, Guiné Equatorial, São Tomé e Príncipe e Togo, 1982; Zâmbia 1991. Pode-se afirmar que a Eritreia já estava em situação merecedora desta categorização quando de sua independência. Após referendo patrocinado pela ONU, o país ficou independente da Etiópia em 24 de maio de 1993 e passou a ser um dos PMDs já em 1994.

${ }^{77}$ Dados do CIA World Factbook (Central Intelligence Agency, 2016).
} 
experiência da guerra. É interessante, contudo, que a proximidade de alguns deles pode ajudar a criar um componente de "boa vizinhança", que neutralizaria os efeitos desestabilizadores dos vizinhos em guerra. Deles, apenas Gâmbia, Lesoto, Guiné-Bissau e São Tomé e Príncipe não fazem fronteira com outro país pacífico. Os dois primeiros são um enclave dentro do território de algum outro Estado maior (Senegal e África do Sul, respectivamente), enquanto o último é um arquipélago e por isso não faz fronteiras com ninguém. Guiné-Bissau, por sua vez, está cercado entre Senegal e Guiné - países que tiveram guerras civis ou conflito não-estatais. Há, contudo, algumas diferenças no registro de guerras civis nas vizinhanças onde tais países estão localizados. Em um extremo, apenas um dos três países que fazem fronteira com o Maláui passou por guerra civil em sua história (Moçambique). No outro extremo, todos os vizinhos de GuinéBissau tiveram guerra civil ou conflitos não-estatais.

Figura 4 - PMDs da África que não tiveram guerras civis, conflitos menores ou conflitos nãoestatais

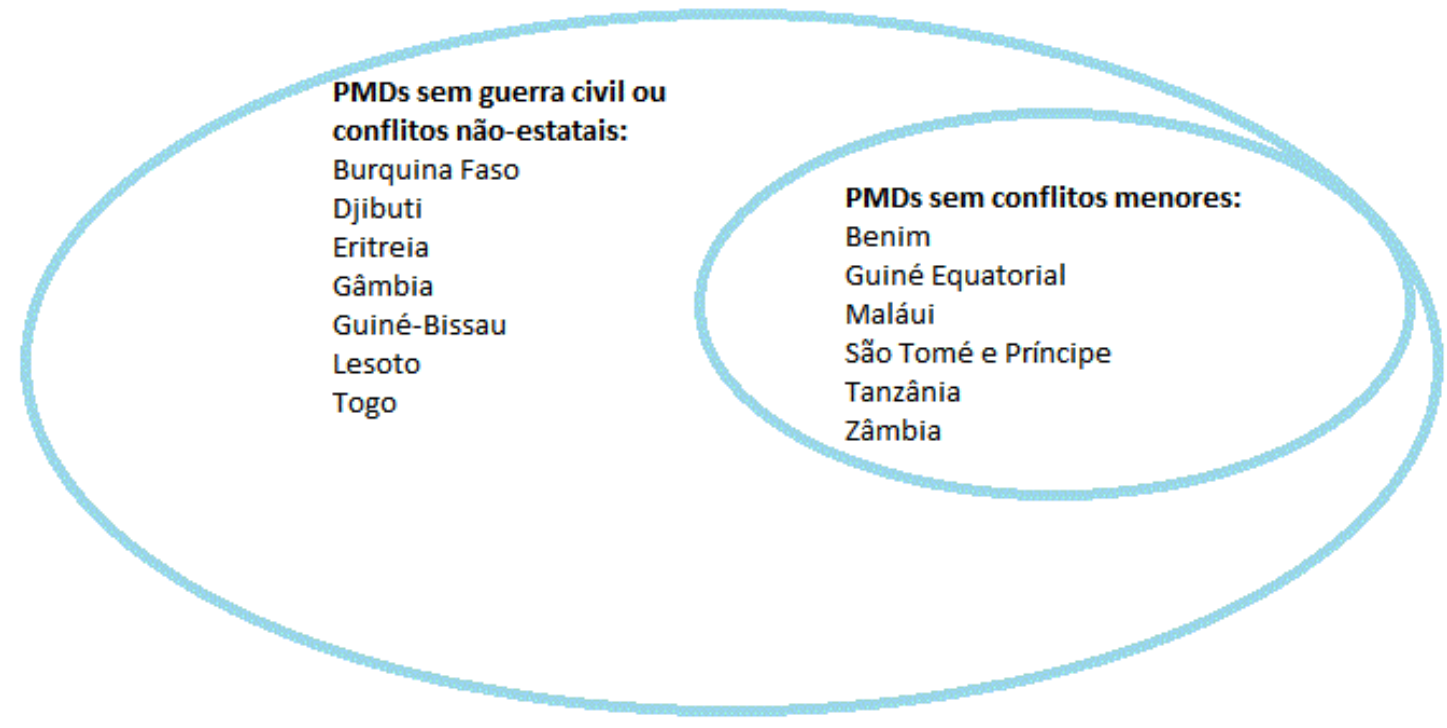

Fonte: Uppsala Conflict Data Program (2016), elaboração própria.

Além disso, deve-se recordar também que apesar de as guerras civis que aconteceram na região dos Grandes Lagos e da África Austral terem sido em boa medida concomitantes, o mesmo não aconteceu na África Ocidental. Isto não apenas demonstra como a má vizinhança pode não ser suficiente para desestabilizar um país como também leva a questionar se a vizinhança ruim é de fato um problema. No caso tanzaniano, por exemplo, poderia ter se esperado que a má vizinhança lhe surtisse efeito entre os anos de 1981 e 1989 quando tanto Quênia e Moçambique passavam por conflitos e entre 1996 e 2001, quando metade dos países com que faz fronteira estive envolvida em conflitos 
menores ou guerras civis. ${ }^{78} \mathrm{O}$ país, contudo, saiu ileso de ambos os períodos. A Eritreia, circundada por vizinhos com histórico e presente de violência e o Djibuti, também demonstra que os efeitos da má vizinhança podem ser neutralizados de algum modo. Nos dois primeiros anos de independência, todos os vizinhos da Eritreia (Djibuti, Etiópia e Sudão) passavam por conflitos menores. Entre 1995 e 1996 e 1998 e 2015, a Etiópia continuou passando por conflitos menores enquanto o Sudão esteve em guerra civil durante quase todo esse tempo. ${ }^{79}$

Segundo, os regimes políticos também não parecem ter sido responsáveis pela ausência de guerras civis nesses países. Apesar do argumento de que democracias bem estabelecidas e autocracias tendem oferecer menos risco para a eclosão de uma guerra civil do que qualquer estágio intermediário, esses treze países passaram longos períodos e grandes parcelas de sua história em regimes intermediários. Essas proporções, além de tudo, são bastante próximas de países que foram palco de guerras civis e falência estatal. Togo, Zâmbia e Tanzânia, por exemplo, passaram em média 42,4\% de suas histórias independentes sob regimes que não eram nem democracias nem autocracias. Essa proporção é semelhante à de países como Sudão, Costa do Marfim, Uganda, Ruanda e República Democrática do Congo que passaram em média 42,2\% de suas histórias em regimes intermediários. ${ }^{80}$

\footnotetext{
${ }^{78}$ O Burundi foi palco de conflitos menores entre 1996 e 1999 e de uma guerra civil de dois anos iniciada em 2000. A República Democrática do Congo esteve em guerra civil entre 1996 e 2000 e foi palco de conflitos menores em 2001. A violência em Uganda chegou a escalar em 1996 para uma guerra civil e depois perdeu o status para conflitos menores entre 1997 e 2001. Por fim, Ruanda foi palco de conflitos menores entre 1996 e 1997 e 1999 e 2000. Nos anos de 1998 e 2001, a escalada da violência permitiu classificá-la como guerra civil

${ }^{79}$ Neste caso, um dos fatores que podem ter auxiliado a Eritreia a não sofrer consequências da guerra civil no Sudão é que o foco da violência se deu na região sul (que culminou com a independência do Sudão do Sul em 2011) e no oeste do país, com a crise do Darfur. Ou seja, ambos bastante distantes do território eritreu.

${ }^{80}$ Center for Systemic Peace (2016). Não se pode descartar taxativamente que a relação entre regimes intermediários e a falência estatal e a eclosão de guerras civis. Os seis países deste grupo que não tiveram nem mesmo conflitos menores desde sua independência são também aqueles que passaram menos tempo sob regimes intermediários,
} 


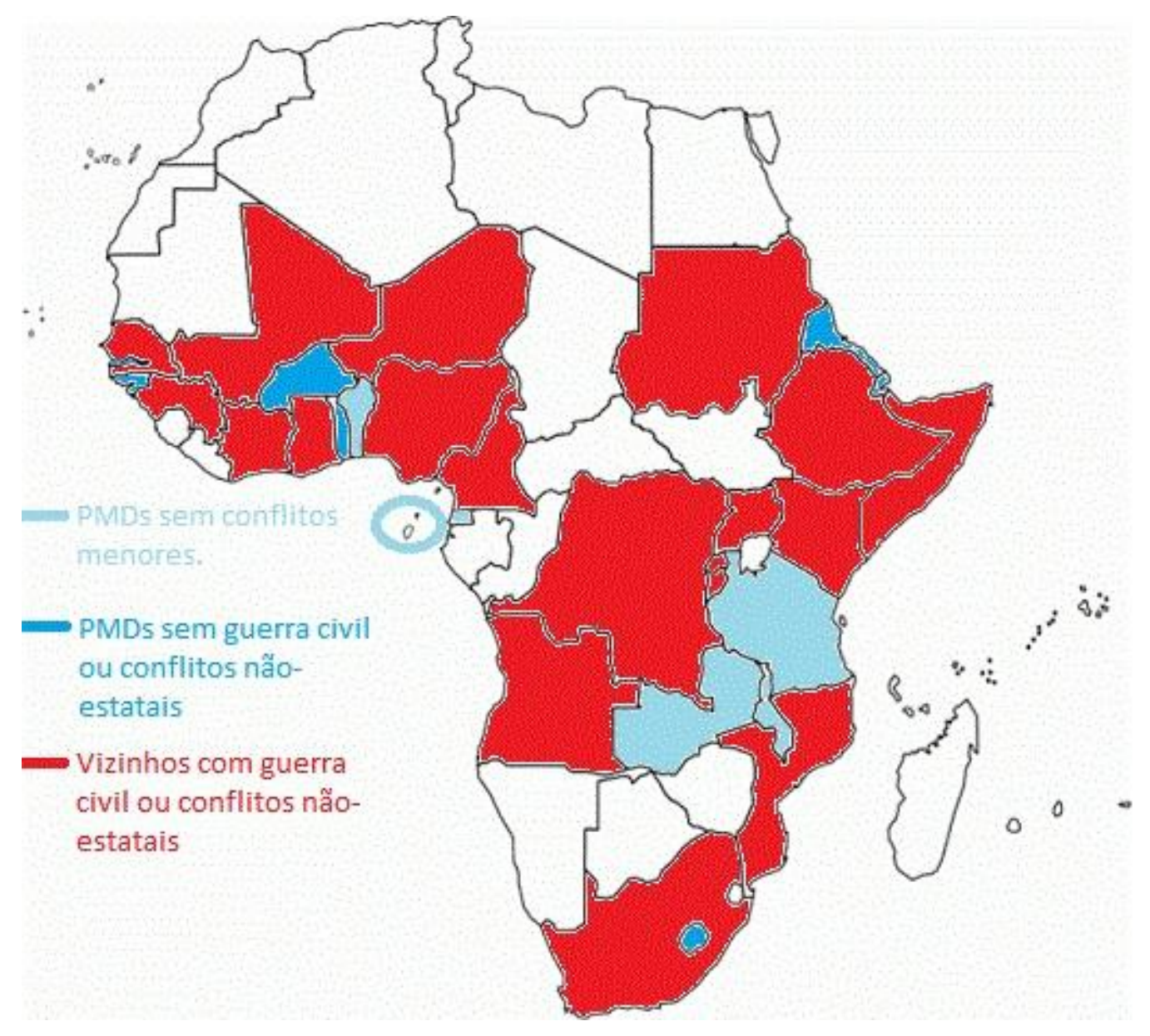

Fonte: Uppsala Conflict Data Program (2016), elaboração própria.

Terceiro, a questão das etnias também não contribui com a ausência de guerras civis nestes países. Tanto com base no banco de dados do Ethnic Power Relations (EPR) - que mede a quantidade de grupos étnicos politicamente relevantes que houve na história do país - e do Political Ethnic Relevant Groups (PREG) - que mede o fracionamento étnico da população - e também na medição de Englebert (2000b) sobre a legitimidade horizontal (LEGITH) dos Estados africanos, não se pode afirmar qualquer relação entre a diversidade étnica e a falência estatal ou a eclosão de guerras civis. Eles não apresentam nenhuma regra ou padrão no tocante à diversidade étnica ou quantidade de grupos étnicos politicamente relevantes e alguns deles são bastantes semelhantes inclusive a Ruanda e Libéria, países cujos conflitos costumam ser amplamente explicados pela questão étnica. Dentre eles, a Zâmbia é o país que tem a maior quantidade de grupos étnicos

\footnotetext{
${ }^{81}$ Os países em branco ou não fazem fronteira com os PMDs que nunca tiveram guerra civil ou conflitos menores ou então são não-PMDs que não tiveram guerras civis ou conflitos menores.
} 
politicamente relevantes (sete) e também o país etnicamente mais fragmentado, mas não é o que tem menos legitimidade horizontal. Além disso, Djibuti e Togo têm a mesma quantidade de grupos étnicos politicamente relevantes que Ruanda, mas também não tiveram guerras civis e Benim e Tanzânia têm fragmentação étnica semelhante à Libéria e Ruanda respectivamente, mas nem por isso sucumbiram às guerras civis e colapso estatal. A tabela 1 mostra a diversidade étnica dos treze países analisados neste capítulo e os compara com Libéria e Ruanda.

Tabela 2 - Questão étnica nos PMDs que não passaram por guerras civis e Ruanda e Libéria

\begin{tabular}{lccl}
\hline País & EPR & PREG & LEGITH \\
\hline & Sem Guerra Civil & & \\
Burquina Faso & 1 & 0,00 & 0,574 \\
Djibuti & 2 & N/A & 0,114 \\
Eritreia & 5 & N/A & N/A \\
Gâmbia & 5 & 0,37 & 0,829 \\
Guiné-Bissau & 5 & 0,05 & 0,558 \\
Lesoto & 1 & 0,00 & 0,990 \\
Togo & 2 & 0,49 & 0,591 \\
& Sem Conflitos & & \\
Benim & Menores & & \\
Guiné Equatorial & N/A & 0,30 & 0,675 \\
Maláui & 3 & 0,19 & 0,150 \\
São Tomé e Príncipe & N/A & 0,55 & 0,340 \\
Tanzânia & 6 & N/A & 1,000 \\
Zâmbia & 7 & 0,59 & 0,741 \\
\hline Libéria & $\mathbf{0}$ & $\mathbf{0 , 6 2}$ & 0,443 \\
Ruanda & $\mathbf{2}$ & $\mathbf{0 , 2 6}$ & $\mathbf{0 , 5 6 4}$ \\
\hline
\end{tabular}

Fonte: Cederman, Min e Wimmer (2009); Posner (2004); e Englebert (2000b), elaboração própria.

Por fim, tampouco é possível explicar a ausência de guerras nestes países pelo fato de não possuírem ou não dependerem de recursos naturais tais como diamantes, petróleo ou cobre. Apesar de a grande maioria destes treze países ser classificada como "países com recursos escassos" pelo Banco Africano de Desenvolvimento (BAD), a parcela que os recursos naturais ocupam nas exportações de alguns destes países é próxima à relação em países onde houve guerras e, neste ponto, há importantes semelhanças com países que passaram por conflitos. ${ }^{82}$ Por exemplo, a Guiné Equatorial (que nunca passou por guerra

\footnotetext{
${ }^{82}$ Dos treze PMDs que não tiveram guerra civil na história, apenas Guiné Equatorial e Tanzânia estão listadas como países ricos em recursos (African Development Bank, 2007).
} 
civil) não apenas é altamente dependente da exportação de petróleo e outros hidrocarbonetos (91,7\% das exportações em 2014) como também tem suas vendas internacionais mais concentradas nesses produtos do que o Sudão (que tem uma das guerras civis mais longas da história), cujas exportações de petróleo representaram $66,1 \%$ do total em 2014. Igualmente, o cobre representa quase $60 \%$ das exportações tanto da Zâmbia quanto da República Democrática do Congo (African Economic Outlook, 2014). A primeira, contudo, jamais passou por guerra civil enquanto a segunda passa por uma guerra civil que transpassou suas fronteiras e foi conhecida como a "Guerra Mundial da África". ${ }^{83}$

Até este momento, verificou-se que não se pode afirmar que os treze países analisados neste capítulo não experimentaram a falência estatal e a guerra civil devido à ausência de fatores aos quais são atribuídas as origens de muitas guerras no continente. No geral, estavam em regiões politicamente instáveis e violentas, passaram boa parte de sua história com um regime político que não era nem uma democracia bem estabelecida ou uma autocracia, têm populações cuja complexidade étnica semelhante foi alegada como a causa de guerras civis alhures e também são bastante dependentes de recursos naturais assim como países que sucumbiram à violência política e viram suas instituições estatais entrarem em colapso. Assim sendo, a pergunta permanece: quais as causas da paz nestes Estados? Como será exposto a seguir, é oportuno afirmar que a resposta a tal pergunta está na manutenção ou resgate das instituições políticas pré-coloniais e na forma como novas instituições foram construídas após a independência desses Estados. Além disso, é possível que a geografia e a demografia de tais países também tenham ajudado bastante. Portanto, é provável que tenha sido a autoridade do Estado e de suas instituições que foi capaz de evitar que esses países falissem e de garantir-lhes uma história pacífica até o presente momento.

\subsection{Continuidade das civilizações, geografia política e legitimidade estatal}

Este argumento ergue-se primeiro no fato de que os treze países deste capítulo se encontram nas categorias C e B de autoridade entre 1996 e 2011. Destarte, não seria exagero imaginar que que tal status seria verdadeiro também fora do período para o qual os dados quantitativos estavam disponíveis. ${ }^{84}$ Além disso, por estarem entre os países

\footnotetext{
${ }^{83}$ Prunier (2009).

${ }^{84}$ Apenas a Guiné-Bissau atingiu a categoria mais baixa no período. O país teve conflitos menores entre 1998 e 1999.
} 
menos desenvolvidos do mundo, o argumento de que os países africanos teriam sacrificado o desenvolvimento em detrimento da estabilidade e da sobrevivência do regime parece ser facilmente aplicável. Contudo, o fato de que eles apresentaram diferentes correlações entre autoridade e desenvolvimento no período entre 1996 e 2011 leva a questionar tal argumento. Por um lado, as melhorias desenvolvimentistas de Benim e Gâmbia no período não foram acompanhadas pelo aumento da autoridade estatal. Neste sentido, a correlação alta e negativa entre autoridade e desenvolvimento nestes dois países pode justamente indicar a necessidade de o governo sacrificar o desenvolvimento para garantir a autoridade estatal. Por outro lado, Tanzânia e Maláui apresentaram correlações altas e positivas em ambas as variáveis no intervalo analisado. Tal como dito anteriormente, isto não significa necessariamente uma relação causal entre elas.

Nos indicadores em separado que compõem a variável autoridade, é impressionante como esses treze países tiveram melhor desempenho em garantir a ausência da violência política comparado com o desempenho na eficácia da governança e da nomocracia. Apenas a Guiné-Bissau (1996-98) e o Togo (2005) atingiram a categoria mais baixa em tal critério. Este poderia ser mais um fator de queixas da população e que poderia gerar maior tensão e revoltas tanto populares quanto armadas, uma vez que a eficácia da governança e a nomocracia melhorariam a vida das pessoas e dariam mais previsibilidade e regras que norteariam o comportamento dos atores civis e políticos. Em situações de baixa eficácia da governança e de nomocracia frágil, isto é, em situações nas quais o Estado tem dificuldade de impor leis e cobrar o respeito a elas, é de se esperar que a população crie regras próprias e mecanismos de cobrá-las (justiça com as próprias mãos, por exemplo) e questione ou julgue que não seja importante cumprir as leis formuladas pelo governo. No entanto, esse não é o quadro indicado por três pesquisas de opinião sobre o assunto em diferentes momentos. No geral, a pesquisa indicou que quase $90 \%$ dos entrevistados nos PMDs concordam com a frase "é importante obedecer ao governo no poder independentemente de para quem você votou", conforme mostra a tabela 2.

Dos países nos quais tal pesquisa não foi realizada, é preciso fazer um breve comentário sobre a Eritreia. Desde sua independência de jure em 1993, o país vem sendo governado sob pulso firme do autocrata Isaias Afwerki. A constituição de 1997 ainda não foi implementada e as eleições previstas para o mesmo ano foram adiadas indefinidamente devido à escalada da tensão com a Etiópia (que culminou na guerra entre os dois países entre 1998 e 2000). Além disso, um relatório do Conselho de Direitos 
Humanos das Nações Unidas (CDHNU) de 2015 afirmou que a população eritreia era "controlada, silenciada e isolada" e que o regime sistematicamente mantinha vigilância sobre seus cidadãos e tolhia seus direitos de movimento, expressão e opinião. Ademais, o mesmo relatório afirmou a existência do "governo pelo medo" no país. ${ }^{85}$ Tal estado das coisas leva a crer que a pesquisa não foi realizada no país devido ao medo da população em expressar-se e também que a estabilidade política do país tem sido garantida justamente devido ao pulso firme do governo.

Tabela 3 - Obediência ao governo, independentemente de para quem se votou ${ }^{86}$

\begin{tabular}{llll}
\hline País & 2005-2006 & $\mathbf{2 0 1 1 - 2 0 1 3}$ & $\mathbf{2 0 1 4 - 2 0 1 5}$ \\
\hline $\begin{array}{l}\text { Burquina Faso } \\
\text { Djibuti }\end{array}$ & Sem guerra civil & & \\
Eritreia & & $86,8 \%$ & $89,4 \%$ \\
Gâmbia & & \\
Guiné-Bissau & & & \\
Lesoto & $91,3 \%$ & $89,2 \%$ & $87,1 \%$ \\
Togo & & $92,0 \%$ & $92,1 \%$ \\
& & \\
Benim & Sem conflitos & & \\
Guiné Equatorial & $96,4 \%$ & $93,5 \%$ & $94,2 \%$ \\
Maláui & $79,7 \%$ & & $88,4 \%$ \\
São Tomé e Príncipe & & $88,2 \%$ & $88,5 \%$ \\
Tanzânia & $91,4 \%$ & & $88,3 \%$ \\
Zâmbia & $86,5 \%$ & $92,4 \%$ & \\
\hline Total & $89,1 \%$ & $90,7 \%$ & \\
\hline Fonte: Afrobar & & \\
\hline
\end{tabular}

Fonte: Afrobarometer (2015), elaboração própria.

De todo modo, os níveis de obediência política sugerido pelas pesquisas de opinião mencionadas acima são tão altos que é pouco provável que pelo menos naqueles Estados sejam devido ao carisma do governante ou que tenham sofrido e venham a sofrer alguma mudança abrupta. Neste sentido, é possível que se trate de uma cultura política desenvolvida há muito tempo naquelas populações. Se isto for assim, pode-se afirmar que seja devido ao fato de que as instituições políticas no geral não são estranhas à população. Afinal, como foi dito no segundo capítulo, não era a ideia de Estado e fronteiras que era

\footnotetext{
${ }^{85}$ A/HRC/29/42 de 04 de junho de 2015.

${ }^{86}$ As células em branco significam que a pesquisa não foi realizada no país e ano correspondentes.
} 
nova aos povos africanos quando a colonização começou, mas sim o Estado e as fronteiras impostas pela colonização.

Desta forma, faz sentido uma breve análise sobre as unidades políticas pré-coloniais existentes nos territórios correspondentes aos Estados atuais em questão. Todos os países deste grupo (com a exceção de São Tomé e Príncipe, cujas ilhas eram desabitadas quando da chegada dos portugueses na década de 1470) foram criados e sobrepostos a Estados tradicionais, ora dividindo-os, ora suprimindo-os. Como já dito anteriormente, isto não foi capaz de apagar da memória coletiva das sociedades a vida em um Estado, instituição política primeira e fundamental, e às vezes, em um Estado de direito. Por isso, o fato de os iorubás terem sido divididos durante a colonização não alterou sua experiência e herança política, uma vez que já viviam organizados em Estados, ainda que diferentes daqueles que se formariam após as independências. Também os cheuas, que vivem nos atuais Maláui e Zâmbia, e os ewés, no atual Togo, viviam em sistemas políticos que foram partidos pela colonização (Englebert, 2000b).

Além destes, algumas unidades políticas pré-coloniais desenvolveram complexidade institucional importante que não apenas lhes permitiu garantir a estabilidade e sobrevivência do Estado por longo tempo, mas também a expandir-se e serem reconhecidos como atores políticos com os quais se deveria negociar e até mesmo celebrar tratados, tal como aconteceu com a Eritreia, que virou protetorado italiano após um acordo celebrado e mal interpretado entre a Itália e o imperador etíope Menelik II. Ao longo do século XIX, Estados comerciais evoluíram de forma significativa e desenvolveram-se dando origem um sistema de coordenação de populações. O Daomé (que ocupou boa parte do atual Benim), por exemplo, construiu uma rede de palácios em todo o interior do Estado de modo não apenas a remodelar a paisagem política, mas também a afirmar o poder e a autoridade da dinastia e de seus burocratas em terras mais distantes da capital. Para garantir a estabilidade e diminuir a influência de facções dentro do aparato estatal, o reino contava com indivíduos leais ao rei designados a relatar-lhe as ações dos agentes do estado (Monroe, 2010).

A grande questão, contudo, é que estes Estados tradicionais não compartilhavam o mesmo modo de projeção do poder e da autoridade sobre o território que seus congêneres coloniais e pós-coloniais. Neste sentido, a existência de relações de vassalagem dentro dos limites territoriais dos Estados pré-coloniais e os diferentes graus de complexidade 
institucional que eles detinham poderiam ter culminado em diferentes relações de poder e percepções dos novos Estados por parte das populações. Foi por isso que houve algumas tentativas em medir o grau de diferença dos sistemas políticos pré-coloniais com relação aos pós-coloniais. Seguindo a medição proposta por Morrison, Mitchel e Padden (1989), é interessante notar que dos treze países analisados neste capítulo, em média, aqueles que não tiveram nem mesmo conflitos menores eram mais parecidos com o que os autores chamaram de Estado no período pré-colonial. Ou seja, a estrutura do Estado nestes trezes PMDs é condicionante do comportamento dos agentes. Não à toa, mesmo a questão das etnias nestes países (que muitos teóricos afirmam serem mobilizadas em contextos de subdesenvolvimento crônico) era semelhante a países que passaram por guerras civis com causas atribuídas a tal fator. Isto indica que há algo capaz de inibir os impulsos dos agentes políticos a pegar em armas e promoverem o colapso do Estado: nos PMDS pacíficos - como se demonstra - é a estrutura estatal.

Tabela 4 - Grau de Semelhança com Estado de Morrison, Mitchell e Paden (1989) ${ }^{87}$

\begin{tabular}{|c|c|c|c|}
\hline SEM GUERRA CIVIL & $\begin{array}{l}\text { Grau de } \\
\text { semelhança com } \\
\text { Estado }\end{array}$ & $\begin{array}{l}\text { SEM CONFLITOS } \\
\text { MENORES }\end{array}$ & $\begin{array}{l}\text { Grau de } \\
\text { semelhança com } \\
\text { Estado }\end{array}$ \\
\hline Burquina Faso & 1,25 & Benim & 2,76 \\
\hline Djibuti & & Guiné Equatorial & 1,00 \\
\hline Eritreia & & Maláui & 1,80 \\
\hline Gâmbia & 1,60 & $\begin{array}{l}\text { São Tomé e } \\
\text { Príncipe }\end{array}$ & \\
\hline Guiné-Bissau & 1,67 & Tanzânia & 1,67 \\
\hline Lesoto & 3,00 & Zâmbia & 2,00 \\
\hline Togo & 1,33 & & \\
\hline
\end{tabular}

Para olhar a estrutura desses Estados e sua conexão com os sistemas políticos tradicionais, é necessário olhar primeiro para a geografia e a demografia dos países em questão. Um dos motivos para tanto é a maneira em que o poder é projetado do centro para a periferia nos Estados africanos desde épocas pré-coloniais. Destarte, apesar de os Estados africanos pós-coloniais não serem os mesmos que os tradicionais, os constrangimentos que a geografia lhes impõe continuam sendo os mesmos, com retornos decrescentes em escala, de acordo com os custos e benefícios sobre a taxação e a projeção

\footnotetext{
${ }^{87} \mathrm{O}$ grau de semelhança mede "para cada país a média do sistema político pré-colonial, com sociedades acéfalas marcando 1, chefaturas sem importância marcado 2; e chefaturas tribais maiores e reinos, 3". (Englebert, 2000b, p. 162). Em suma, quanto maior o valor, maior a semelhança com os Estados póscoloniais.
} 
da autoridade estatal (isto é, quanto mais longe do centro do Estado, maior o custo para projetar o poder e cobrar impostos e tributos e, consequentemente, menor o retorno para o Estado).

Como quase não houve mudanças territoriais na África desde as independências, a geografia pode ser tratada como uma constante. As secessões da Eritreia em 1993 e do Sudão do Sul em 2011 não parecem ter alterado as dinâmicas de projeção do poder sobre território e população e é muito pouco provável que haja outra secessão no continente. Apesar da existência de grupos separatistas como o MNLA e a FNLC, seu poder para conseguir separar o território que pretendem libertar é questionável. Além disso, o fato de a Eritreia ser um dos treze PMDs que nunca passou por guerra civil tampouco muda as conclusões sobre o tamanho dos Estados e sua aplicabilidade a esse seleto grupo de países. Esses países ainda desafiam a tradicional máxima de que quanto maior o território do Estado, melhor seu desempenho. Também para estes, territórios pequenos representam menos desafios para o Estado projetar e consolidar sua autoridade sobre sua população e, porque não dizer, sobre seu território. Este padrão que vigorava antes e durante a colonização permaneceu no período das independências. Isto é, o território ainda importava menos do que o tamanho da população e a acessibilidade a ela. Não à toa, a cobrança do "imposto por cabeça" foi muito comum na África durante o período colonial e se manteve em muitos Estado após a independência (Wallerstein, 2005). Por isso, quanto menor o território, maior a acessibilidade à população e maior a chance de conseguir dividendos provenientes dos impostos cobrados por pessoas.

Assim como os demais Estados africanos, estes treze países também foram desenhados de modo a garantir determinada densidade demográfica e assim torná-los lucrativos para as metrópoles. Foi por isto que o Alto Volta (atual Burquina Faso) foi extinto em 1932 pela França e sua parte mais meridional mais populosa foi anexada à Costa do Marfim, auxiliando assim os agricultores locais a recrutar mão de obra (Gervais \& Mande, 2000). ${ }^{88}$ Também os ingleses tentaram promover tal política de ajustes territoriais e demográficos entre suas colônias na tentativa de maximizar a rentabilidade advinda dos impostos cobrados. Logo após o fim da I Guerra Mundial e a aquisição de

\footnotetext{
${ }^{88} \mathrm{O}$ restante do território foi anexado para o Níger e para o Sudão Francês (atual Mali), ambos ainda eram possessão francesa. O Alto Volta, contudo, foi reestabelecido em 1947 devido a pressões de grupos locais cujas ações acabaram alterando o resultado da taxação e da lucratividade dos territórios adicionados a essas outras colônias.
} 
colônias alemãs na África, a Inglaterra tratou de criar a Federação da África Oriental, que unificaria as colônias de Tanganica, Quênia e Uganda. A oposição do Reino de Buganda, contudo fez com que a federação não fosse efetivada. Ao contrário, os ingleses conseguiram criar a Federação da África Central que, entre 1953 e 1963, unificou os protetorados da Niassalândia (atual Maláui), da Rodésia do Sul (atual Zimbábue) e da Rodésia do Norte (atual Zâmbia).

O que torna essas experiências coloniais interessantes para a análise da geografia é que - tomando como base os Estados atuais - elas tentaram combinar territórios com geografia política favorável com territórios de geografia política neutra, difícil ou de hinterlândias. O Alto Volta, de geografia política favorável, fora repartido com duas colônias de grandes hinterlândias (Níger e o Sudão Francês) e com uma colônia de geografia política difícil (Costa do Marfim) e a Niassalândia e a Rodésia do Norte, de geografia política neutra foram unidas à Rodésia do Sul, de geografia política favorável. Como resultado, pode-se afirmar que as alterações não reproduziram as melhorias na autoridade e o incremento na rentabilidade da taxação que eram esperados uma vez que teriam diluído os benefícios daquelas com geografias políticas favoráveis em unidade não favoráveis. ${ }^{89}$

O período pós-colonial, como já dito, não trouxe mudanças nos territórios e na demografia das ex-colônias africanas e, com isso, também não alterou as oportunidades e os constrangimentos que eram apresentados à projeção e à consolidação do poder estatal sobre sua população e território. Dentre os treze PMDs que nunca tiveram guerra civil nem experimentaram a falência de Estado, é digno de nota que oito deles apresentam geografia política favorável; dois deles, neutra; e um, difícil. ${ }^{90}$ Essa geografia praticamente imutável guarda algumas características importantes também para a transição do período colonial para o pós-colonial. No caso dos países com geografia política favorável, sua conformação territorial dá a impressão de que foi a inspiração dos

\footnotetext{
${ }^{89}$ No caso específico da Federação da África Central, houve boas expectativas com relação aos possíveis resultados da unificação das Rodésias e da Niassalândia. Contudo, tal otimismo ficou muito mais concentrado na produtividade econômica (comandada por colonos brancos) e não nas possibilidades de projeção da autoridade e dos retornos advindos da taxação. Além disso, as melhores expectativas concentravam-se na economia da Rodésia do Sul, curiosamente a única que tinha geografia política favorável à projeção do poder (Hance, 1954).

${ }^{90}$ A análise de Herbst (2000) desconsidera São Tomé e Príncipe pelo fato de ser um arquipélago e, portanto, ter passado por experiências diversas com relação ao território. O autor também não classifica o Djibuti.
} 
colonizadores na hora de fazer o cálculo sobre o tamanho e a população a ser repartida nas novas colônias.

No caso do Benim, por exemplo, o desenho territorial do Estado compreendeu um pouco mais do que os alcances do antigo Daomé, Estado tradicional que sucumbiu à colonização. Também o território de Burquina Faso representa de certa forma o território dos Reinos Mossi, cujo processo de centralização e consolidação do poder de Uagadugu estava em curso quando da chegada dos franceses (Tiendrebeogo, 1963). Além disso, Gâmbia, Guiné-Bissau, Guiné Equatorial, Lesoto e Togo são tão pequenos que se pode afirmar que "suas distribuições de densidade de população são obviamente bastante favoráveis à consolidação política", uma vez que as maiores concentrações populacionais são de fácil alcance da capital (Herbst, 2000, p. 155). Por fim, foi exatamente a geografia desfavorável da Etiópia que permitiu a secessão da Eritreia em 1993, uma vez que os dois núcleos populacionais do país (anterior à secessão) estavam separados sendo que o localizado na região de Asmara (atual Eritreia) era de difícil projeção para o poder de Adis Abeba. ${ }^{91}$

Dos três países que não tem geografia favorável à projeção e consolidação da autoridade estatal, Maláui e Zâmbia (de geografia política neutra) não chegam a ter problemas com a densidade demográfica e sua distribuição ao longo do território. Apesar de o território do primeiro ser longo, ele também é pequeno o bastante para evitar que orientações políticas regionais (norte e sul) tornem-se um problema para a projeção de sua autoridade e consolidação do poder sobre o território. Quanto ao segundo, sua população bem distribuída e sua capital Lusaca ficam exatamente no centro demográfico do país e não geram incidentes, uma vez que o grosso da população e do território estão ao alcance da autoridade estatal.

Único país do grupo com geografia política difícil, a Tanzânia apresenta desafio um pouco diferente dos demais. Suas áreas menos povoadas estão circundadas por regiões com populações bastante maiores e foram alvo de uma parte específica da Ujamaa, poltícia econômica dos anos 1960 e 1970 que nacionalizou instituições financeiras

\footnotetext{
${ }^{91}$ A secessão eritreia e a Guerra Etio-Eritreia (1998-2000) são abordadas sob esta perspectiva em minha dissertação de mestrado "Conflitos no Chifre da África: oportunidades e constrangimentos da difusão do poder”, PPGRI “San Tiago Dantas” UNESP/UNICAMP/PUC-SP, 2010.
} 
privadas e estabelecimentos comerciais e de produção importantes que existiam no país. ${ }^{92}$ Especificamente, a Ujamaa vijijini (Ujamaa nas vilas, em suaíle), primeiro incentivou e depois forçou a mudança de milhares de pessoas para vilas nas quais se viveria seguindo um modo de produção camponês. Um dos argumentos utilizados pelo governo tanzaniano na época é que aqueles que fossem viver nas vilas "estariam muito mais acessíveis para o trabalhador de extensão agrícola, o dispensário rural, a escola primária e outros agentes de desenvolvimento". Além disso, em um de seus últimos discursos como presidente do país, Julius Nyerere defendeu a Ujamaa e afirmou que a política teve "sucesso considerável no desenvolvimento rural e nas políticas de taxação" (Pratt, 1999, p. 139; Johnson \& Korica, 2015, p. 36). Com base nesta afirmação, pode-se ver que a Ujamaa Vijijini teve como objetivo não apenas o desenvolvimento e a superação da pobreza, mas também trazer parte da população para as áreas onde o poder do Estado estava mais consolidado. $^{93}$

Um outro fator interessante que contribuiu para que outros países da África Subsaariana não passassem por guerras civis, contudo, está presente apenas menor grau entre os treze PMDs pacíficos do continente. Deles, apenas Lesoto e São Tomé e Príncipe tem este fator, que Englebert (2000b) chamou de "legitimidade vertical". O primeiro tem tal tipo de legitimidade por ter mantido as instituições pré-coloniais após a independência e o segundo, por não ter tido assentamento humano prévio em seu território quando da chegada dos colonizadores portugueses no século XV. A colonização das duas ilhas que compõem o país lusófono começou na década de 1490 quando - após fracassar em atrair colonos para as novas ilhas - a Coroa portuguesa começou a enviar para lá os indesejados do país (judeus e cristãos novos, em sua maioria). Esses novos colonos passaram a ocupar-se do plantio de cana de açúcar e passaram a adquirir mão-de-obra escrava para o trabalho na lavoura. Esses angolares passaram a compor importante grupo demográfico

\footnotetext{
${ }^{92}$ A Ujamaa (cuja tradução aproximada para o inglês seria "familyhood") foi a base do sistema socialista implementado por Julius Nyerere na Tanzânia a partir de 1967. Na Declaração de Arusha, os princípios de tal sistema foram descritos como a ausência da exploração, o controle dos principais meios econômicos pelos camponeses e trabalhadores e democracia. A declaração expôs também a preocupação com o desenvolvimento agrário após muito foco ter sido dedicado às indústrias e também a criação de uma identidade nacional tanzaniana por meio do uso do idioma suaíle (The Arusha Declaration and the TANU'S Policy on Socialism and Self-Reliance, 1967).

${ }^{93}$ O sucesso da Ujamaa Vijijini é discutível. Por um lado, Ibhawoh e Dibua (2003) descriminaram as três principais falhas desta política apontadas pela literatura: a imposição de sua criação e implementação, o uso da força para garantir a deslocamentos em massa para as vilas e o papel dos burocratas, que passaram a desviar recursos destinados para a sobrevivência das mesmas. Por outro lado, Ibott (2014), mesmo reconhecendo que políticos arruinaram os ideais e as práticas da Ujamaa Vijijini, afrma que a política foi capaz de superar a pobreza e a subordinação das mulheres nas vilas.
} 
nas ilhas e até mesmo desafiaram o jugo português nas duas ilhas em meados do século XVII. No final do século XIX, o sistema de roças - que havia permitido que São Tomé e Príncipe se tornasse o maior produtor de cacau do mundo - acabou por empoderar demais os proprietários de terra que, como consequência, praticavam abusos contra boa parte da mão-de-obra local. As revoltas daí decorrentes pavimentaram o caminho para a independência do país em 1972, três anos antes da queda do regime salazarista em Portugal. De então, o país foi governado pelo presidente Manuel Pinto da Costa, líder do Movimento de Libertação de São Tomé e Príncipe (MLSTP), até 1991, quando conduziu reformas democráticas e possibilitou que outros partidos acedessem ao poder pela via democrática. Costa ainda voltaria à presidência do país como candidato independente em 2011 para mais um mandato de cinco anos.

Ainda que se possa atribuir o caráter pacífico da história do país ao fato de ter tido suas instituições construídas juntamente com sua população, é necessário considerar a influência de seu território também. É verdade que a população que para lá se mudou e seus herdeiros não conheceram outro Estado ou outros tipos de instituições políticas naquele território que não aquele no qual eles mesmos tiveram papel na construção. É igualmente verdade, por outro lado, que tais instituições podem ter sido criadas de acordo com os desafios territoriais e demográficos que se lhe apresentavam. Por mais que a literatura sobre o tamanho e a forma dos Estados africanos não costume destacar atenção para os países insulares, cabe aqui a indagação se em maior ou menor grau também eles não tiveram semelhantes oportunidades e constrangimentos da projeção e consolidação da autoridade estatal. O tamanho extremamente diminuto do país faz com que a densidade demográfica não seja um problema para o Estado assim como acontece com Gâmbia, Guiné-Bissau, Guiné Equatorial, Lesoto e Togo. Por outro lado, o fato de o país estar dividido em duas ilhas pode complicar a projeção de poder em uma delas, forçando uma presença bastante forte do Estado em ambas, tal como as complicações que Senegal tem com o movimento separatista de Casamança. ${ }^{94}$ No caso são-tomeense, o fato de $95,5 \%$

\footnotetext{
${ }^{94} \mathrm{O}$ caso do Senegal (geografia política difícil) é no mínimo curioso. Apesar de ser bastante pequeno, sua geografia política é dificultada justamente por um país de geografia política favorável, a Gâmbia, que é quase um enclave dentro do território senegalês com quem faz fronteira a sul, leste e norte. Os dois principais pólos demográficos do Senegal são assim separados pela Gâmbia e dificultam que Dacar lide com o movimento separatista de Casamança. É difícil saber se a continuidade da Confederação da Senegâmbia (1981-89) teria ajudado Dacar nesta questão. Se por um lado as forças senegalesas poderiam marcar mais sua presença em Casamança sem ter de passar pelo território gambês, por outro é pouco provável que os benefícios da geografia favorável da Gâmbia surtissem algum efeito positivo para o Senegal.
} 
da população do país residir na Ilha de São Tomé ${ }^{95}$ - onde fica a capital - e estar necessariamente limitada pelo mar aproxima o país mais ao caso daqueles com tamanho diminuto do que daquele como movimento separatista.

Estes fatores constantes (geografia política e legitimidade vertical) parecem ter contribuído bastante para fortalecer a autoridade estatal nestes treze países. De fato, apesar de sua média no indicador agregado de autoridade estatal estar na mesma categoria (C) que a média dos demais países no período entre 1996 e 2011, seu valor médio é mais altos do que a média do continente (0,396 e 0,362, respectivamente). Estes valores são ainda mais favoráveis (obviamente) quando se analisa a variável ausência de violência política e terrorismo. Neste caso, o valor médio de toda a África Subsaariana para o período analisado é de 0,455 contra 0,474 do grupo de Estados em questão. Apesar de análise qualitativa ter abordado um período muito maior do que esses dezesseis anos que permitiram a análise quantitativa utilizada nesta pesquisa, não parece ser exagero considerar que os fatores constantes presentes na estrutura do Estado deram uma importantíssima contribuição para sua estabilidade política e assim para prevenção de sua falência e eclosão de guerras civis.

\subsection{Costume, resiliência e capilaridade da autoridade estatal}

Assim, além da geografia, a existência de Estados tradicionais nos territórios correspondentes aos países analisados neste capítulo (à exceção de São Tomé e Príncipe, cujas ilhas eram desabitadas quando da chegada dos portugueses) parece ter contribuído de maneira importante para a estabilidade política e a ausência de violência política em tais países. No entanto, apenas esse fato ainda não explica a manutenção e o fortalecimento da autoridade estatal, uma vez que instituições alienígenas foram implantadas e tiveram de competir com as fontes de autoridade anteriores, que eram baseadas em fatores outros além da coerção e continuaram bastante influentes não apenas durante a colonização, mas também após ela.

A acomodação, incorporação ou supressão da fonte de autoridade dos líderes tradicionais compôs um elemento importante na construção desses novos Estados. Antes da colonização eles participavam ativamente da política local, desempenhando papel na governança e na nomocracia do Estado tradicional, sua participação após a colonização continuou existindo e não passou desapercebida. Essas autoridades tradicionais passaram

\footnotetext{
${ }^{95}$ Instituto Nacional de Estatística (2010).
} 
a representar um desafio aos novos líderes nacionalistas, uma vez que haviam tido um papel ambivalente durante a colonização e que não havia nenhum tipo de garantia de que esse quadro seria alterado após as independências. Durante a colonização, as autoridades tradicionais (chefes e líderes dos Estados tradicionais que coexistiram com o Estado colonial) ora apresentaram resistência ao jugo europeu, ora ocupavam posições burocráticas oferecidas pelos colonizadores. Após as independências, os novos chefes de Estado e de governo não confiavam na possibilidade de que tais líderes iriam ajudá-los a constituir o novo Estado.

Desta forma, seguindo a regra do continente, os PMDs que nunca passaram por guerra civil desenvolveram processos de "africanização" de sua burocracia sem inicialmente promover ou incentivar a "indigenização" das instituições de governança. Isto é, visavase a troca dos quadros de funcionários das instituições coloniais, substituindo os europeus por funcionários africanos apesar de não se pretender inicialmente desmantelar as instituições construídas pelos colonizadores ou substitui-las pelas instituições locais outrora existentes. ${ }^{96}$ A construção de um esquema e de um aparato de poder coeso no pósindependência deu-se de forma geral com base na supressão das autoridades tradicionais. Por isso, os líderes tradicionais foram sendo removidos das posições que ocupavam na burocracia dos Estados coloniais. A Tanzânia, por exemplo, tratou de abolir os sistemas que davam poder aos líderes tradicionais (chiefdoms, em inglês) enquanto o Mogho Naba, regente dos Mossi, foi sendo gradativamente marginalizado na política do Alto Volta. Tal fato não significou, contudo, o fim dos poderes tradicionais nestes Estados. Ao contrário, os líderes tradicionais passaram a utilizar as instituições pós-coloniais para atingir a objetivos políticos. Na própria Tanzânia, onde se buscou desde o início a centralização do poder no Estado por meio da Ujamaa, Nyerere tinha conhecimento de que simplesmente tentar neutralizar tais influências poderia quebrar os laços que uniam o governo local com o povo, que ainda muito se orientava pela influência dos líderes tradicionais. Assim, sua deposição dos cargos oficiais traduziu-se não em confronto político direto ou na sua supressão, mas sim na sua nomeação em oficiais do governo local em suas próprias aldeias (Herbst, 2000). ${ }^{97}$

\footnotetext{
${ }^{96}$ Isto não se aplica a São Tomé e Príncipe uma vez que lá não houve instituições políticas pré-coloniais. Isto foi, segundo Mamdani (1996), a regra da África Subsaariana.

${ }^{97}$ Citação de Henry S. Bienen, Tanzania: Party Transformation and Economic Development (Princeton: Princeton University Press, 1970).
} 
A luta pela consolidação da autoridade estatal passou assim não só pela disputa sobre quem seriam os tomadores de decisão mais influentes sobre as populações, mas também sobre a posse da terra. Neste ponto, as políticas adotadas pelos Estados pós-coloniais variaram entre a propriedade individual, que favorecia as autoridades e práticas tradicionais, e a estatal, que as desafiava e ao contrário do que se poderia esperar, o maior desafio às práticas tradicionais de posse da terra foi feito não pela oposição ou supressão, mas pelo seu reconhecimento e legalização afinal tais políticas refletiam o processo e resultado da disputa entre as autoridades estatais e as autoridades tradicionais. Desta forma, tal como aconteceu na Gâmbia, o Estado foi capaz de lotear e demarcar a terra de modo que as práticas tradicionais já não se fizeram mais relevantes. Com base nisso, Herbst (2000) sistematizou os tipos de propriedade da terra na grande maioria dos Estados africanos e classificou-os de acordo com a existência de propriedade privada e estatal da terra e do reconhecimento explícito do mandato costumeiro sobre a terra. Sua sistematização foi reproduzida parcialmente na tabela 5 .

Tabela 5 - Propriedade da terra nos PMDs sem guerra civil

\begin{tabular}{|c|c|c|c|}
\hline País & Propriedade Privada & Propriedade Estatal & $\begin{array}{l}\text { Reconhecimento } \\
\text { explícito do } \\
\text { mandato costumeiro }\end{array}$ \\
\hline & Sem guerras civis & & \\
\hline Burquina Faso & Não & Existe & Não \\
\hline \multicolumn{4}{|l|}{ Djibuti } \\
\hline \multicolumn{4}{|l|}{ Eritreia } \\
\hline Gâmbia & Existe & Existe & Sim \\
\hline Guiné-Bissau & Existe & Não & Sim \\
\hline Lesoto & Não & Significante & Não \\
\hline \multirow[t]{2}{*}{ Togo } & Existe & Existe & Sim \\
\hline & $\begin{array}{l}\text { Sem conflitos } \\
\text { menores }\end{array}$ & & \\
\hline Benim & Existe & Existe & Não \\
\hline Guiné Equatorial & & & \\
\hline Maláui & Significante & Significante & Sim \\
\hline São Tomé e Príncipe & & & \\
\hline Tanzânia & Não & Significante & Não \\
\hline Zâmbia & Não & Significante & Sim \\
\hline
\end{tabular}

Fonte: Herbst (2000), elaboração própria.

Utilizando-se das mesmas classificações e atribuições de valor usadas pelo autor, fica difícil estabelecer algum padrão na forma da posse da terra e nos critérios que a 
determinam. ${ }^{98}$ A diferença do valor médio atribuído dos nove PMDs que não tiveram guerra civil que cujas formas de posse fundiária foram avaliadas pelo autor e para os quais tal valorização foi feita não é muito diferente do valor médio para todo o resto do continente (2,56 e 2,50, respectivamente), o que apontaria para o fato de que os critérios de posse e a posse efetiva da terra podem não corresponder à estabilidade e autoridade do país. No entanto, esse delta é maior se comparado o valor médio dos países que não passaram por guerras civis ou conflitos não-estatais com aqueles que tiveram tal experiência (2,73 e 2,20 respectivamente). Do mesmo modo, uma diferença maior aparece ao separar os nove países mencionados na tabela entre aqueles que não tiveram guerras civis durante sua história independente e aqueles que não tiveram nem mesmo conflitos menores (2,2 e 3,0 respectivamente). Isto indica, portanto, uma correlação entre a variedade da posse da terra (propriedade privada significante, propriedade estatal significante e reconhecimento explícito do mandato costumeiro) e a estabilidade do país.

Para o autor, estes resultados demonstraram uma importante forma de acomodação e incorporação da lei costumeira e dos líderes tradicionais nos países africanos. O Maláui (que apresentou a maior soma de todos os países que analisou) possuía uma "estrutura de posse altamente dualista com grandes propriedades ocupando grandes faixas de terra". Estas propriedades rurais são resquícios ainda dos primeiros assentamentos, de quando "fazendeiros brancos tomaram boa parte da extensão da terra". Aqui, o que realmente desafiou a posse costumeira da terra não foi a legislação nacional, mas sim o crescimento do setor privado. Por outro lado, Burquina Faso e Senegal (que apresentaram baixas somas) tiveram um trato distinto bastante distinto no tocante à posse da terra. No primeiro, o governo não tem força de trabalho para compor os conselhos locais que são, na maior parte do país, baseadas nas estruturas de poder locais enquanto no segundo, as diretrizes que baseariam as decisões sobre a posse da terra não eram claras e os conselhos rurais pouco agiam. Como ele chamou a atenção, o fato de haver ao menos alguma correlação entre o desenho nacional (geografia política favorável) e o sucesso em romper com a posse de terras costumeira indica que "as políticas domésticas tem importado menos do

\footnotetext{
${ }^{98} \mathrm{O}$ autor sistematizou 38 países da África Subsaariana, deixando de lado os países insulares e aqueles para os quais não conseguiu dados suficientes. Desses, quinze (sendo dez PMDs analisados neste capítulo) nunca passaram por guerra civil ou conflito não-estatal e Quando considerou que a propriedade "privada" ou "estatal" da terra existia, o autor marcou um ponto para o país e quando tal tipo de propriedade era "significante", marcou 2. Também, marcou um ponto para o reconhecimento explícito do mandato costumeiro da terra e nenhum para quando este não houvesse. Um país pode somar no máximo 5. Nenhum país somou zero.
} 
que as estruturas impostas externamente herdadas do período colonial”. Isto é, o Estado seria soberano, mas não proprietário das terras, sendo a geografia assim um obstáculo para usurpar o poder dos líderes tradicionais (Herbst, 2000, p. 188 e 194).

Contudo, o fato de os PMDs que nunca passaram por guerra civil apontarem uma correlação entre não ocorrência de guerra civil e a diversificação da posse da terra indica que os líderes tradicionais podem ter mais poder do que se imaginava e até mesmo estarem sendo não apenas acomodados, mas também incorporados no aparato estatal. Além disso, uma tentativa de atualizar e completar os dados sobre a propriedade da terra nesses PMDs apontam para um movimento em favor do reconhecimento dos mecanismos tradicionais de posse de terra. Na Eritreia, a lei reconhece o tsilmi e a diesa como formas de arrendamento e posse da terra. ${ }^{99} \mathrm{Na}$ Guiné Equatorial, a lei explicitamente prevê a "posse tradicional" da terra e estabelece um "Conselho dos Povoados" que regulamenta e media contenciosos sobre o assunto (FAO). No Lesoto, a instituição da propriedade estatal das terras teve impacto mínimo nas áreas rurais onde o jugo costumeiro prevalece. ${ }^{100}$ Por fim, no Maláui - onde quase $80 \%$ das terras do país são terras costumeiras - uma nova política lançada em 2002 fortaleceu ainda mais o sistema já dualista de posse da terra. ${ }^{101}$

Para esta pesquisa, por outro lado, o cruzamento dos dados levantados por Herbst sobre a posse e os critérios para a posse da terra com os dados coletados aqui sobre a eficácia da governança para o período entre 1996 e 2011 reforçam ainda mais a relação das autoridades e leis costumeiras com a autoridade estatal. Como era de se esperar, os países que nunca passaram por guerra civil tiveram um valor médio neste indicador melhor do que aqueles que já haviam passado (0,339 e 0,316, respectivamente) e o valor médio dos PMDs presentes na tabela acima que nunca passaram por conflitos menores é

\footnotetext{
${ }^{99}$ Proclamação de Terras n ${ }^{\circ} 58$ de 1994 . O Tsilmi é um sistema que garante a posse da terra por praticamente toda a vida do mandatário e o Diesa garante a posse da terra às vilas. Ambas as formas de posse fundiária existiam na Eritreia antes mesmo da chegada dos italianos, que tentaram alterar o primeiro na década de 1930 alegando que eram a fonte de muitos contenciosos (FAO).

100 O Ato de Terras de 1979 deu aos "proprietários tradicionais" a opção de converter suas terras em um direito de arrendamento, que poderia ser vendido ou alugado mediante aprovação do Ministério do Interior. A conversão automática das terras aconteceu apenas em áreas agrícolas julgadas estratégicas pelo governo (FAO).

${ }^{101}$ A Política de Terras de 2002 manteve e fortaleceu as distinções entre a propriedade privada, estatal e costumeira da terra. Além disso, ela mudou a nomenclatura utilizada no Ato de Terras de 1965 e passou a referir-se por "terras costumeiras" o que antes era chamado de "fundo de terras africanas". Na prática, os chefes, subchefes e os homens grandes das aldeias ocupam-se da proteção das terras costumeiras contra “estrangeiros" (FAO).
} 
maior do que aqueles que apenas não passaram apenas por guerras civis $(0,353$ e 0,327 , respectivamente). A única diferença com relação ao achado indicado no parágrafo anterior é que aqui a diferença entre o valor médio dos nove PMDs com dados na tabela acima e que nunca passaram por guerra civil com dados na tabela e o do continente todo é a menos expressiva (0,354 e 0,336, respectivamente). Ou seja, os países pacíficos têm sistema de terras dual e maior efetividade da governança, o que diminuiu a probabilidade de conflitos não-estatais sobre a terra.

Como se vê, a combinação das autoridades e instituições tradicionais com a capacidade administrativa do Estado reforçou de modo ainda mais intenso a autoridade estatal, seguindo tendência do continente. O que chama a atenção entre os PMDs que nunca passaram por guerra civil em sua história independente é sua maior parte não viu em tais autoridades uma concorrência ou obstáculo para a construção do Estado, mas sim uma força complementar. A própria opinião pública nesses países tende a corroborar esta afirmação. Primeiro, há uma confiança popular bastante alta e crescente nos líderes tradicionais de tais países. Mesmo na Tanzânia, onde se buscou abolir o sistema de chefias desde a independência, a confiança nesses líderes atingiu 60,1\% da população em 2014. No mesmo ano, a parcela da população que declarava confiar nos líderes tradicionais em Burquina Faso chegou a 81,3\%. Na zona rural, estas taxas são ainda mais altas: nos dois países mencionados a cima, a confiança atinge $62,4 \%$ e $87,1 \%$, respectivamente. A maior diferença entre as opiniões da população urbana e rural foi no Benim, onde disseram confiar nos líderes tradicionais $58,1 \%$ da população urbana e $75,2 \%$ da rural. ${ }^{102}$ No geral, $65,9 \%$ dos entrevistados nesses países disseram confiar nos líderes tradicionais, mais do que o resultado agregado do continente.

Segundo, há também nestes países uma vontade popular em aumentar a influência dos líderes tradicionais nos governos locais. Nos seis PMDs que nunca passaram por guerras civis em que tal pesquisa foi realizada, 56,9\% dos entrevistados disseram querer aumentar o grau de influência dos líderes tradicionais nos governos locais. Duas coisas

\footnotetext{
102 Pesquisa feita pelo Afrobarometer (2015) perguntou aos entrevistados "quanto você confia em cada um dos seguintes, ou não ouviu falar suficientemente sobre eles para dizer? Líderes tradicionais". Os respondentes podiam escolher entre "nada", "bem pouco", "um pouco" ou "bastante". Os números apresentados aqui são a soma das respostas "um pouco" e "bastante". A pesquisa entrevistou 11985 pessoas em Benim, Burquina Faso, Maláui, Tanzânia, Togo e Zâmbia e também foi feita em outros 15 países do continente, totalizando 46743 entrevistados. Duas pesquisas semelhantes foram realizadas em $2003 \mathrm{e} \mathrm{em}$ 2009. Seus resultados fortalecem a interpretação apresentada acima. Também foram realizadas tais pesquisas na Argélia, Egito, Marrocos e Tunísia, que não foram consideradas nesta análise uma vez que tais países estão fora da área geográfica que constitui o objeto de estudo desta pesquisa.
} 
chamam a atenção neste ponto. A primeira é que a vontade em fortalecer o papel de tais líderes nesses países é proporcionalmente maior nas zonas rurais $(56,2 \%)$, onde os líderes têm maior apoio e confiança, do que nas urbanas $(48,9 \%)$. A segunda é que a parcela de entrevistados favorável a aumentar o poder dos líderes tradicionais nos governos locais é menor no resultado agregado em todos os 20 países onde tal entrevista aconteceu do que nesses seis PMDs que nunca passaram por guerra civil (53\% e 56,9\% respectivamente). Tais resultados não indicam necessariamente uma saturação do modelo ou desejo por recuo na tendência tanto no menor quanto no maior grupo de países analisados: em ambos, a proporção de respondentes que querem que a influência permaneça igual foi praticamente a mesma (19\% dos entrevistados nos 20 países e 19,6\% dos entrevistados nos seis PMDs que nunca passaram por guerra civil e onde a pesquisa foi realizada). Do grupo menor, apenas na Tanzânia $(35,1 \%)$ a vontade em aumentar a influência de tais líderes não superou $50 \%$ dos entrevistados. ${ }^{103}$

Apesar de demonstrarem uma satisfação geral com o papel das autoridades tradicionais na governança das comunidades locais, esses números mostram também que a taxa de rejeição a elas foi maior nos países onde elas tiveram mais avanço, ou seja, nos PMDs que nunca passaram por guerras civis. Isto é natural e não significa que estejam perto do retrocesso. Mesmo com uma parcela maior da população querendo diminuir a influência dos atores tradicionais, a taxa corresponde a 10,8\% da população desses seis países (11,4\% na zona rural). Individualmente, Benim, Burquina Faso e Tanzânia são os que tiveram a maior rejeição: $10,4 \%, 14,7 \%$ e $19 \%$ respectivamente. No primeiro caso, essa proporção baixa representa apenas uma rejeição natural a um processo político e pode também representar a insatisfação com algum líder específico e não com a ideia geral de permitir a influência dessas autoridades. Nos outros dois países, por outro lado, o número mais alto é reflexo da política de proibição e recusa em reconhecer as instituições tradicionais. Surpreendentemente, a satisfação com as autoridades tradicionais foi maior nas áreas urbanas desses países. No entanto, a diferença para as

\footnotetext{
${ }^{103}$ Pesquisa feita pelo Afrobarometer (2009a) perguntou aos entrevistados "você acha que a influência que os líderes tradicionais que governam sua comunidade local deve aumentar, permanecer igual ou diminuir?". Os respondentes podiam escolher entre "diminuir muito", "diminuir um pouco", "permanecer igual", "aumentar um pouco" e "aumentar bastante". Os números apresentados aqui são a soma das respostas "aumentar um pouco" e "aumentar bastante". A pesquisa entrevistou 7208 pessoas em Benim, Burquina Faso, Lesoto, Maláui, Tanzânia e Zâmbia e também foi feita em outros 13 países do continente, totalizando 27713 entrevistados. Também foram realizadas tais pesquisas na Argélia, Egito, Marrocos e Tunísia, que não foram consideradas nesta análise uma vez que tais países estão fora da área geográfica que constitui o objeto de estudo desta pesquisa.
} 
áreas rurais - onde os Estados têm mais dificuldade de se fazer presente - é irrisória (57\% e $56,2 \%$, respectivamente).

Desse modo, é compreensível que a incorporação de tais autoridades tenha sido na verdade um subterfúgio do Estado para garantir sua presença nas áreas mais remotas e garantir assim os efeitos de sua governança e autoridade. Ao invés de vê-las como concorrentes e como uma ameaça, preferiram enxergá-las como um complemento à suas forças e, ao fazê-lo, diminuíram os custos da projeção do poder estatal nas áreas mais afastadas de seu território. Com avanços e retrocessos, esta foi a realidade nos PMDs que nunca passaram por guerras civis de geografia política favorável e neutra, mas curiosamente não foi a realidade da Tanzânia, que têm geografia política difícil e teoricamente seriam os que mais se beneficiariam de tal movimento. ${ }^{104}$

Entre os que têm geografia política favorável, destacam-se o Benim e o Togo pelo grau de organização dessas autoridades tradicionais. No primeiro, seu papel crescente acabou culminando na criação da Associação dos Reis do Benim (ARB) em 1991 e do Conselho de Administração das Famílias Reais de Abomei (CAFRA) em 2002, sendo que esta última mantém relações políticas formais com o governo do país. Além disso, o país também foi sede em agosto de 1999 da Conferência Mundial dos Reis, Rainhas, Chefe Tradicionais e Líderes Religiosos sobre Prevenção de Conflitos no Século XXI, admitindo o papel que tais autoridades possuem na estabilidade política dos Estados africanos. No segundo, onde os líderes tradicionais haviam sido regulamentados como funcionários públicos do Estado em 1959 (um ano antes da independência), o ressurgimento político aconteceu enquanto classe ao lançar a União dos Chefes Tradicionais do Togo (Englebert, 2002; van Rouveroy, 1987).

No Maláui e na Zâmbia - os dois países do grupo com geografia política neutra - as autoridades tradicionais tiveram forte influência e papel na governança desde suas independências. Como já foi dito, ambos reconhecem explicitamente o mandato

\footnotetext{
${ }^{104}$ Entre esses PMDs com geografia política favorável à projeção do poder e consolidação da autoridade, Burquina Faso foi o único que buscou banir e neutralizar a influência dos líderes tradicionais. Dentre as medidas tomadas logo após a independência estava a proibição de substituir os chefes tradicionais logo após sua morte por um período determinado. No entanto, a influência dos líderes tradicionais continuou a fazer-se presente na cena política do país e de maneira paradoxal. Por um lado, eles compõem uma entidade que está acima das lealdades partidárias e do debate político nacional. Por outro, o processo de democratização do país permitiu-lhes envolver-se diretamente na política dos partidos e passaram a ser importantes pois são capazes de mobilizar grandes números de eleitores para determinado partido. Desta forma, a democratização do país acabou servido de mecanismo para o reconhecimento formal dos líderes tradicionais (Hagberg, 2007; Baldwin, 2016).
} 
costumeiro das terras e, além disso, foram países onde o reconhecimento das autoridades e das instituições tradicionais foram utilizadas para a democratização da governança rural. No primeiro, a descentralização do poder e a abertura política de 1994 que culminou no fim do governo de trinta anos de Hastings Banda permitiu que líderes tradicionais participassem mais abertamente da política de tal modo que chegaram a ser mais influentes que os próprios governos locais, já que estavam mais próximos do eleitorado rural. Talvez por isso e como forma de tentar equilibrar a política tradicional e moderna, o Senado do país (que seria ocupado unicamente por líderes tradicionais) nunca tenha saído do papel e sua previsão na Constituição de 1994 tenha sido retirada sete anos depois. Mesmo assim, os líderes tradicionais malauianos ainda são reconhecidos como interlocutores importantes por ONGs, agentes externos e doadores internacionais e desempenham função judiciária ad hoc nas comunidades (Englebert, 2002; Chiweza, 2007; Muriaas, 2009).

Na vizinha Zâmbia, a abertura política no começo dos anos 1990 foi acompanhada de envolvimento maior dos líderes tradicionais na tarefa de mobilizar o eleitorado rural. Essa nova atuação política deles não foi uma surpresa uma vez que desde a independência em 1964, o presidente Kenneth Kaunda havia tentado subordiná-los à disciplina do Partido Unido da Independência Nacional (PUID), trazendo-os para a atividade política e fazendo-os ocupar postos da administração pública. Por isso, ainda hoje tais líderes estão no topo de instituições que conseguem cobrar impostos, resolver disputas locais e alocar terra. Assim como todo processo político, este também não é harmônico. Em 2014, um dos mais influentes líderes tradicionais escreveu ao jornal Lusaka Times uma carta aberta ao então presidente Michael Sata denunciando o que chamou de "guerra aos chefes", ou seja, uma série de medidas que vinham sendo postas em prática nos últimos 20 anos voltadas a diminuir o poder dos líderes tradicionais. ${ }^{105}$

Também durante os 27 anos do governo de Kaunda, ressurgiu no país uma entidade política que havia tomado parte e participado das negociações de independência com o Reino Unido: os Lozi da Barotselândia. Até a abertura política, eles gozaram de certa

105 Mwinelubemba Chitimukulu Kanyanta-Manga II do povo Bemba afirmou que nem mesmo durante o período colonial "os direitos tradicionais e culturais, bem como a dignidade dos governantes tradicionais, foram tão desprezados quanto hoje”. Conforme a denúncia, a Lei de Terras de 1995 autorizava os líderes tradicionais a ceder compulsoriamente as terras à Presidência do país e o Projeto de Política de Terras de 2002 introduziram a possibilidade de mudança de status das terras costumeiras para estatais assim como o Projeto de Constituição de 2010 feito pela Conferência Constitucional Nacional pretendia condicionar o uso das terras costumeiras à aprovação parlamentar (Sosala, 2014). 
autonomia e até mesmo privilégios advindos de Lusaca, não obstante a tácita oposição que faziam ao governo. A abertura política e a consequente eleição de Frederick Chiluba em 1991 não atenderam às demandas dessa entidade conforme esperam. Por isso, chegouse até a iniciar um processo no sistema judiciário do país reivindicando maior autonomia e a secessão do Barotselândia. De certo modo, a pressão política que exerceram foi tamanha que é possível afirmar a relação entre tais episódios e a restauração da Casa dos Chefes em 1996 (Baldwin, 2016; Englebert, 2002). ${ }^{106}$

A Tanzânia, por sua vez, é um país cuja falta de incorporação dos poderes tradicionais ao Estado e até mesmo a não ocorrência de seu ressurgimento demonstra que houve outras formas de compensar a dificuldade que a geografia impôs à autoridade estatal. Como já dito, ela tem geografia política difícil para a projeção do poder e consolidação da autoridade estatal e por isso seria um país que bastante se beneficiaria em incorporar tais autoridades. No entanto, isto não aconteceu. As autoridades tradicionais foram tratadas como inimigas do projeto de consolidação nacional desde o momento da independência do país. Um motivo bastante atribuído para tanto é que a ênfase na construção da nação dos novos países dissolveu outras identidades e enfraqueceu os líderes tradicionais uma vez que, como consequência, perderam a influência sobre as populações locais, tal como aconteceu na Tanzânia.

Lá - assim como em boa parte do continente - a construção do Estado passou por regime unipartidário e por políticas de orientação socialista que acabaram por suprimir muitas das identidades subnacionais e também por desacreditar autoridades tradicionais. ${ }^{107}$ Esta foi a realidade política tanzaniana entre 1963 e 1992. O estabelecimento do controle nacional do Partido da Revolução (CCM, Chama cha Mapinduzi em suaíle) foi acompanhado da proibição de greves e da criação de uma administração centralizada, capaz de suprimir qualquer tipo de oposição. A Ujamaa Vijijini foi uma medida importante no sentido de construção da nação tanzaniana. Com ela, o governo enfatizava não apenas a cooperação entre os agentes econômicos do país,

\footnotetext{
${ }^{106}$ Criada pelo Ato ${ }^{\circ} 18$ de 1996, a Casa dos Chefes é um órgão consultivo ligado ao Presidente do país sobre questões tradicionais e costumeiras, alocado no Ministério dos Chefes e Assuntos Tradicionais. Ele é composto pelos 288 líderes tradicionais existentes na Zâmbia (MoCTA).

${ }^{107}$ Nos anos de 2004/5, 2008/09, 2011/12 e 2014/15, o Afrobarometer realizou uma série de pesquisas de opinião na África. Em todas elas, a maior parte da população da Tanzânia disse que se sentia mais pertencentes à identidade nacional do que à étnica. Proporcionalmente, tal parte da população nesse país é maior do que o resultado agregado dos PMDs que nunca passaram por guerra civil (Benim, Burquina Faso, Maláui, São Tomé e Príncipe, Togo e Zâmbia) e do que o resultado agregado dos outros 29 países onde foi realizada a pesquisa (Afrobarometer, 2005, 2009, 2012 e 2015).
} 
mas também o que se chamou de "auto-sacrifício racial e tribal". Para tanto, Nyerere aproveitou-se do fato de que toda a população dominava o idioma suaíle (ainda que esta fosse uma língua franca no país e língua-mãe de uma pequena parcela da população) para lançar as bases de uma identidade nacional e linguística (Hesseling, 2000; Martin, 1988).

Uma das implicações diretas que as políticas de supressão ou incorporação das autoridades tradicionais geraram sobre a governança nos países e consequentemente na autoridade estatal foi a construção do juízo que as populações fazem sobre qual o nível em que as leis e as decisões devem ser feitas e quem deve fazê-las. Apesar de a opinião pública nesses países ser tão mutável quanto em qualquer outro lugar do mundo, parece que neles há uma tendência ao consenso sobre tais pontos. Além daquilo que a legislação prevê, o entendimento da população sobre as prerrogativas dos governos central e local, dos líderes tradicionais e até mesmo dos membros da comunidade pode ser fontes de desentendimento na estrutura e assim culminar em sobreposição de autoridades.

Dos seis PMDs que nunca passaram por guerras civis onde se fez pesquisa de opinião sobre o assunto, não houve acordo da população sobre onde reside e quem tem a responsabilidade primária alocar as terras, coletar imposto de renda e resolver disputas locais em apenas três: Burquina Faso, Lesoto e Zâmbia. Nos dois primeiros, a falta de acordo está apenas na questão da alocação de terras, o que demonstra potencial conflito devido ao fato de que a legislação do país prevê apenas a propriedade estatal da terra e não reconhece explicitamente o mandato costumeiro sobre a terra. Apesar de haver um indicativo de que a população entenda que tal função do Estado tenha que ser desempenhada pelas autoridades do nível local, há uma parcela importante dela que atribui tal responsabilidade aos líderes tradicionais, ou seja, a autoridades fora da arena estatal.

A Zâmbia é o único país onde não há acordo em duas funções: a alocação de terras e a resolução de disputas locais. A diferença é que ainda que tais tarefas sejam atribuídas também ao nível local, a primeira tende a ser atribuída aos agentes estatais enquanto a segunda aos agentes não-estatais. Pode-se argumentar que a diferença entre esses três 
países ainda se deve aos efeitos do governo indireto, característica da colonização inglesa no continente, que delegou as funções do Estado a atores locais durante a colonização. ${ }^{108}$

Um outro achado interessante desses números corresponde à prerrogativa de coletar impostos de renda. Na verdade, este é a única prerrogativa onde as maiorias concordaram em todos os países deste grupo onde a pesquisa foi feita. A diferença, contudo, é que a opinião pública estava dividida entre reconhecer tal função como prerrogativa do governo central ou local na Tanzânia, país de geografia política difícil. Em boa medida, isso se deve às políticas empreendidas para compensar as dificuldades criadas por sua geografia e pela demografia, já que uma série de atividades e implementação de políticas foi delegada aos governos locais justamente devido ao fato de que o governo central tem dificuldades de atingir a todos os rincões do território nacional. Em tal país, as relações conflituosas entre as autoridades locais e as organizações comunitárias locais faz com que se recorra frequentemente à intervenção do Estado para resolver tais problemas. ${ }^{109}$ Desta forma, até mesmo as autoridades não-estatais acabam contando com o Estado para tentar asseverar sua autoridade em suas comunidades.

Estas situações indicam uma certa resiliência dos Estados que seguem existindo e operando do ponto de vista legal e por vezes pouco questionado. Os Estados, argumenta Englebert (2009), retêm um comando residual e suas instituições continuam a ter sua autoridade reconhecida pelos demais agentes políticos. Tal resiliência se deve ao fato de a autoridade estatal derivar-se da relação mais que simbiótica entre Estado e lei na qual o Estado é a lei. Até mesmo movimentos separatistas como a Barotselândia, na Zâmbia, mostram-se mais preocupados em controlar as instituições locais do que com a secessão propriamente dita. Não à toa, a liderança Lozi deste decidiu cumprir com o projeto nacional zambiano. Englebert (2005) argumenta que neste e em outros casos, as elites que comandavam tais movimentos estavam mais interessadas em conquistar as benesses oriundas do acesso à estatalidade legal do que na secessão em si. Seguindo sua linha de pensamento, um Estado frágil manteria sua "capacidade de controlar, dominar, extrair, ou ditar por meio da lei”, isto é, manteria seu comando legal já que tais funções dependem menos da efetividade institucional doméstica e mais do status soberano do Estado. Por

\footnotetext{
$108 \mathrm{O}$ governo indireto (indirect rule) foi um sistema de governo colonial utilizado pelo Reino Unido e pela França na colonização da África e da Ásida que aproveitava as estruturas de poder local pré-existentes. Os governantes locais eram mantidos e fortalecidos enquanto a polity tornava-se protetorado do país europeu. ${ }^{109}$ Moore (1996) citado em Englebert (2009).
} 
outro lado, esse Estado frágil já não teria capacidade de garantir ordem e segurança e muito menos implementar políticas coerentes.

Tabela 6 - Responsabilidade Primária de Elementos da Governança do Estado nos PMDs pacíficos ${ }^{110}$

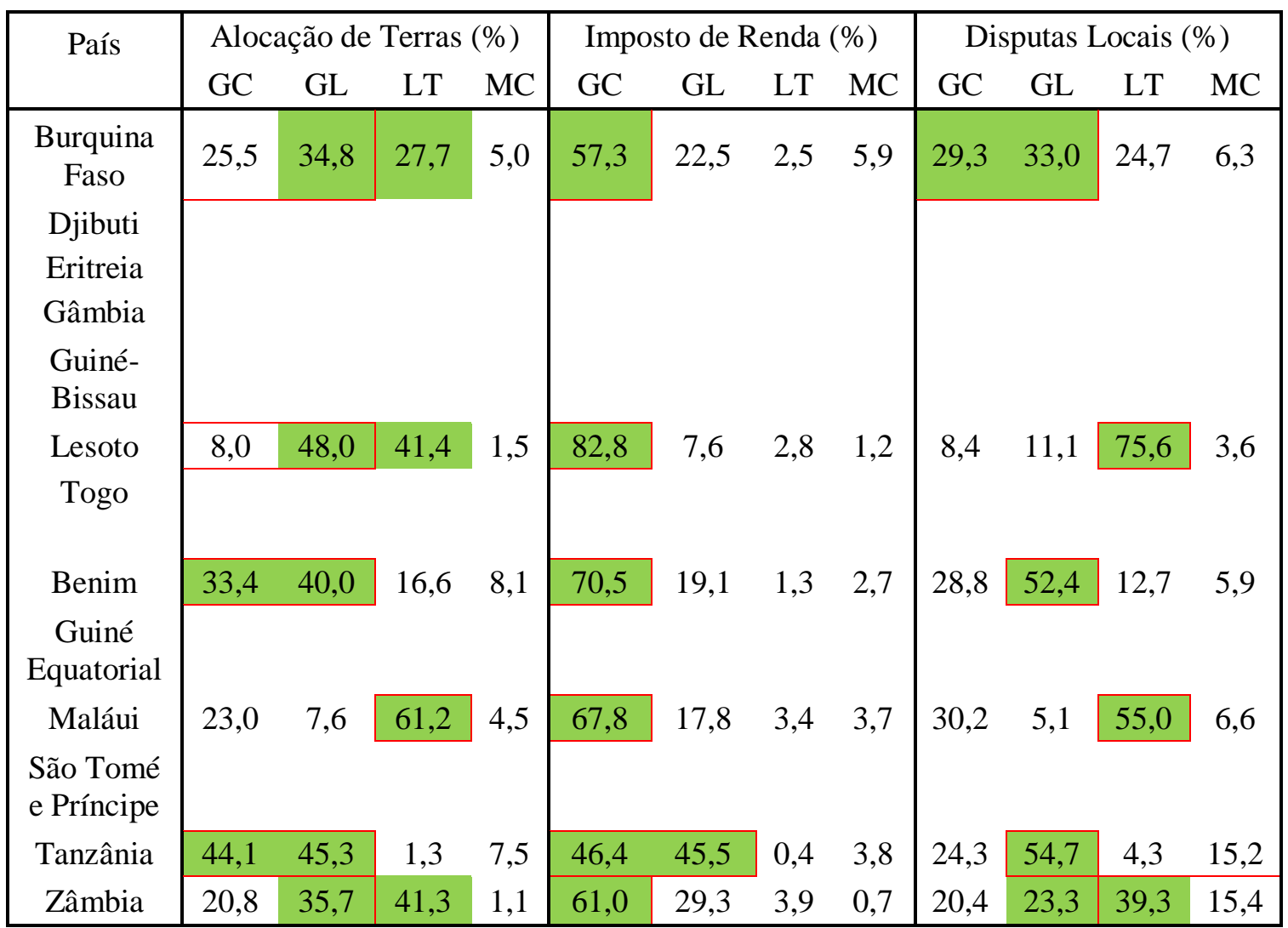

Fonte: Afrobarometer (2009b; 2009c; 2009d), elaboração própria.

No que diz respeito aos PMDs pacíficos, este argumento ajuda parcialmente a explicar sua resiliência e a ausência de guerras civis em sua história no período pós-colonial. Neles, a existência legal de suas instituições e também a falta de recursos para implementar uma série de políticas desenvolvimentistas foram utilizadas para justificar o rótulo de "Estados frágeis". Talvez pela falta de recursos, muitas leis (de trânsito e de padrões higiênicos, por exemplo) não são sequer aplicadas ou têm seu cumprimento cobrado em boa parte do território, independentemente de sua natureza. Em alguns casos, até mesmo as forças policiais não se fazem regularmente presente em muitas cidades ou

\footnotetext{
${ }^{110}$ GC = Governo Central; GL = Governo Local; LT = Líderes Tradicionais; MC = Membros da Comunidade. As células em branco correspondem aos países onde a pesquisa não foi realizada. As células pintadas de verde são o valor ou a soma dos valores mais altos superior ou igual a $50 \%$. Elas indicam o(s) nível(is) a que a metade ou mais da população atribui a responsabilidade desta governança (central ou local). As células com contorno vermelho representam o valor ou a soma dos valores em GC e/ou GL e LT e/ou MC superiores ou iguais a 50\%. Elas indicam se metade ou mais da população atribui essa responsabilidade ao governo (ou seja, ao aparato estatal) ou a agentes não-estatais.
} 
vilas do interior desses países. Além disso, a falta de dados específicos sobre a quantidade de agentes policiais neles não impede de imaginar que tais países tenham taxas bastante baixas de agentes para cada grupo de 100 mil habitantes. ${ }^{111}$ Mesmo assim, eles apresentam taxas de homicídio menores que a taxa média do continente e em alguns casos bastante inferiores à média mundial e em padrões europeus, o que indica que há ordem e segurança em tais países em grau maior do que se esperaria seguindo argumento de Englbert. ${ }^{112}$

\subsection{Considerações finais}

O fato de tais países não terem passado por nenhuma guerra civil desde suas independências não pode, portanto, ser atribuído ao seu nível de desenvolvimento. Se assim o fosse, esses treze países deveriam ter passado ou passar por guerras civis bastante sangrentas e ter visto sua fraqueza culminar em um completo colapso. Como foi demonstrado neste capítulo, a paz nestes países parece ser devida à força da estrutura, isto é, das instituições estatais, que se sobrepõe aos incentivos para que os agentes políticos do Estado peguem em armas para tomá-lo. Destarte, o Estado em si não é questionado significativamente pelos atores políticos e, quando o foi, tratou de incorporar as fontes concorrentes de autoridade em seu aparato de modo a fortalecer sua autoridade sobre seu território.

Isso tudo não significa, contudo, que tais países não sejam instáveis na sua política ou que sejam imunes a crises institucionais. Ao longo de suas histórias, é possível encontrar golpes de Estado, impasses institucionais importantes entre os poderes executivo, legislativo e judiciário e até mesmo períodos nos quais o executivo controlou os outros dois poderes de tal forma que a divisão de poderes não passou de mero conceito, estando inexistente na prática. A questão aqui, contudo, é que o modo que encontraram para compensar as dificuldades na projeção de seu poder e na consolidação de sua autoridade fez com que até mesmo os desafios ao Estado viessem de dentro de suas instituições ou então que atores passassem a integrá-las. Por isso, é possível dizer que as instituições

\footnotetext{
111 Deste grupo, apenas a Gâmbia (265 agentes policiais/100 mil habitantes), Lesoto (125 agentes policiais/100 mil habitantes) e Togo (55 agentes policiais/100 mil habitantes) tinham dados disponíveis. (ONU, 2010).

${ }^{112}$ A taxa de homicídios média para cada 100 mil pessoas nesses quatorze PMDs pacíficos em 2012 foi de 11,23 contra 12,5 de toda a África (incluindo os cinco países da África do Norte). Entre eles os países com as duas taxas mais altas foram Guiné Equatorial $(19,3)$ e Lesoto (38) e os dois com as menores taxas foram Maláui $(1,8)$ e São Tomé e Príncipe $(3,3)$. Os oito PMDs que nunca tiveram guerra civil ou conflitos menores tiveram uma taxa média de 12,63 enquanto os seis PMDs que nunca tiveram nem conflitos menores tiveram taxa média de 9,37 (UNODC, 2013).
} 
estatais se ramificaram de tal modo que, mesmo sendo fracas e às vezes mais simbólicas do que efetivas, o Estado não é mais o prêmio da política. Ao contrário de outros países na África Subsaariana e no mundo em que a queda de um governo significa necessariamente o colapso da ordem política do país, os treze países analisados neste capítulo parecem ter fundações institucionais sólidas o suficiente para ver as mudanças de governo sem a necessidade de se refundar o Estado. Alguns acontecimentos recentes envolvendo processos eleitorais e sucessórios em três países desse grupo ilustram essa afirmação.

Primeiro, a morte do presidente do Maláui Bingu wa Mutharika em 2012 foi sucedida de muitas ações nos bastidores da política para a definição de seu sucessor. Seu irmão, Peter Mutharika orquestrou para impedir que a vice-presidente Joyce Banda assumisse e pudesse então ele ser empossado. $\mathrm{Na}$ época, Banda fez vários pronunciamentos à população, pedindo obediência de todos às leis. Ironia do destino, a mesma Joyce Banda, que teve de lutar para garantir sua posse em 2012, tentou agir em desrespeito às regras eleitorais tentando manter-se no poder após ter perdido as eleições de 2014. Desde então, o país é governando por Peter Mutharika e se ele logrará superar os principais desafios econômicos e políticos do país e implementar reformas de governança que incluam, entre outras coisas, o financiamento partidário ainda permanece uma dúvida e representa-lhe uma excelente oportunidade para pôr em prática seus estudos acadêmicos. ${ }^{113}$

Segundo, a morte do presidente zambiano Michael Sata dois anos depois trouxe ao poder Guy Scott, o primeiro presidente branco democraticamente eleito e também do pósapartheid em um país africano. Scott era vice-presidente de Sata e tinha como função constitucional convocar novas eleições presidenciais no prazo de 90 dias. Nesse período Scott não cedeu a pressões de seu próprio partido para renunciar e também conseguiu passar imune por uma tentativa fracassada de golpe de Estado. Suas pretensões de concorrer à reeleição fracassaram quando a Suprema Corte do país o declarou inelegível pelo fato de seus pais não serem zambianos de nascimento. Em 2015, Edgard Lungu da Frente Patriótica (mesmo partido de Scott) derrotou Hakainde Hichilema do Partido

\footnotetext{
${ }^{113}$ Peter Mutharika formou-se em Direito pela Universidade de Londres (Reino Unido) e tem mestrado e doutorado na mesma área na conceituadíssima Universidade de Yale (EUA). Lecionou na Universidade de Dar es Salaam (Tanzânia) e na Universidade Hailé Selassié (Etiópia), Universidade Makerere (Uganda) e na Universidade Rutgers e Universidade Washington (EUA) e na Escola de Economia e Ciência Política de Londres (Reino Unido). Também foi consultor informal de seu irmão mais velho Bingu wa Mutharika enquanto este ocupava a presidência do Maláui. Entre suas principais publicações, destaca-se Some Thoughts on Rebuilding African State Capability (1998).
} 
Unido para o Desenvolvimento Nacional (PUDN) por uma diferença de apenas $1,66 \%$ dos votos. O candidato derrotado definiu as eleições como "fingidas", mas mesmo assim pediu para que seus seguidores permanecessem calmos.

Em 2015, na Tanzânia, as eleições gerais se aproximavam já com a garantia de que o então presidente Jakaya Kikwete respeitaria o limite constitucional de dois mandatos seguidos e não tentaria concorrer a um terceiro mandato, seguindo a tradição política naquele país desde 1985, quando Mw. Julius Nyerere deixou o poder. As eleições de 2015 que opuseram John Magufuli do CCM (partido dominante do país) e Edward Lowassa do Partido da Democracia e do Progresso (CHADEMA, Chama cha Demokrasia na Maendeleo em suaíle), ex-primeiro-ministro e defector do CCM, eram previstas para terem resultados muito apertados e por isso era considerada imprevisível. O grau de incerteza e tensão foi tamanho que até a Universidade de Dar es Salaam, a maior do país, atrasou seu calendário acadêmico para assegurar a segurança de seus alunos e instalações. Ao contrário do que se esperava, as eleições aconteceram em ambiente calmo e Magufuli foi eleito com quase $60 \%$ dos votos.

Talvez a única dúvida real que exista sobre os treze PMDs pacíficos esteja pairando sobre o futuro da Eritreia. Segundo país mais novo da África, esse Estado de apenas 23 anos de existência oficial tem sido governando com mãos de ferro por Isaias Afwerki que, apesar tê-lo livrado de guerras civis até o momento, já entrou em disputas armadas com todos os seus vizinhos, sendo a mais grave a guerra contra a Etiópia entre 1998 e 2000. A atual onda de refugiados que tem saído do país mostra claramente que algo não vai bem e, por isso, não se pode descartar ainda que a Eritreia não vá colapsar e entrar numa guerra civil nos próximos vinte anos, talvez.

De todo modo, esses treze países têm mostrado que é possível evitar guerras civis e o colapso estatal apesar do subdesenvolvimento. Partindo de realidades distintas no que tange às geografias de seus territórios e a composição étnica e de identidades de suas populações, eles lograram reforçar a projeção de seu poder e consolidar sua autoridade sobre o território de modo a compelir atores políticos a disputarem o governo, mas não o Estado. Deste modo, ainda que haja altos níveis de corrupção e que o governo não esteja emancipado inteiramente da sociedade, nota-se que as instituições estatais (tendo ou não incorporado as autoridades tradicionais) apresentam-se fortes bastante para que os atores políticos prefiram exercer a política de acordo com as regras do jogo. 


\section{Os não-PMDs e construção da autoridade estatal}

No capítulo anterior, analisou-se os treze PMDs que nunca passaram por guerras civis e conflitos não-estatais desde suas independências com o objetivo de demonstrar que o subdesenvolvimento não poderia ser a causa determinante de conflitos em países africanos uma vez que aqueles estavam entre os menos desenvolvidos do mundo e a fim de indicar uma explicação alternativa que pudesse apontar para as causas da paz e da guerra. Deste modo, demonstrou-se que a construção da autoridade estatal desempenha um papel bastante importante neles e garante a estabilidade política e até mesmo certos níveis de governança e conformidade com as leis e determinações dos agentes políticos autorizados a legislar. Neste capítulo, as mesmas hipóteses e procedimentos serão utilizados para averiguar os motivos da paz em um outro grupo de países: os oito países restantes da África Subsaariana que nunca passaram por tais fenômenos em sua história independente e que não estão entre os PMDs.

O objetivo deste capítulo é verificar se os mesmos fatores que impediram aqueles treze PMDs de sucumbir à guerra civil e colapso estatal estão presentes nestes países, também pacíficos. A grande questão neste grupo é que o nível de desenvolvimento mais alto pode ter desempenhado algum papel na garantia da estabilidade política. $O$ primeiro indicativo disto é que estes oito países representam pouco mais da metade dos Estados da África Subsaariana que não estão na categoria dos PMDs. Ou seja, se no capítulo anterior alertava-se para o fato de que dos 34 PMDs da região, treze tinham história pacífica e alegava-se que tal proporção é significativa, neste capítulo salienta-se o fato de que dos quinze não-PMDs da África Subsaariana, oito nunca tiveram guerra civil ou conflitos não-estatais. Isto significa que um maior nível de desenvolvimento pode não ter sido suficiente para garantir-lhes a estabilidade política. Desta forma, se a autoridade estatal tiver níveis menores e menores impactos nestes do que naqueles ela terá de ser descartada como a causa da paz destes países e aí haverá de se atribuir tal pacifismo ao maior desenvolvimento.

Por outro lado, é importante ressaltar que dos oito não-PMDs que nunca tiveram guerras civis, sete também nunca tiveram nem mesmo conflitos menores. Isto é, em comparação ao grupo de países do capítulo anterior, pode-se pensar que o maior 
desenvolvimento auxiliou ao menos a sustentabilidade da paz nestes países. Este pode ser um segundo fator que aponta para a hipótese de que o desenvolvimento possa ter desempenhado um papel na manutenção histórica da paz nestes países. Partindo-se disto, pode-se levantar a hipótese de que um nível mais alto de desenvolvimento implica em menos violência e maior sustentabilidade da paz. Esta proporção não é alterada ao se considerar a natureza continental ou insular território destes países. Os três deles que são arquipélagos (Cabo Verde, Maurício e Seicheles) também nunca tiveram nem mesmo conflitos menores ao passo que dos cinco países restantes, apenas um teve conflitos menores. ${ }^{114}$ Se a geografia pode ter alguma influência sobre isso e sobre o papel que o desenvolvimento desempenha ou não na estabilidade política desses países será abordado mais para frente neste capítulo. Por ora, é importante destacar a representatividade que este grupo tem para o continente e também que é tão heterogêneo quanto o grupo analisado no capítulo anterior.

Primeiro, esses oito países ocupam apenas 6,9\% de toda a superfície da África Subsaariana e representam 16,3\% da quantidade de Estados na região. Apesar de o tamanho médio indicar Estados relativamente pequenos, a realidade não poderia ser mais heterogênea neste quesito. A Namíbia (maior país deste grupo e quarto maior país da África Subsaariana) tem o território 1826 vezes maior que o de Seicheles (menor país deste grupo) e quase 48 vezes maior que o de Lesoto (menor país continental deste grupo). Do mesmo modo, o Zimbábue, país mais populoso desta amostra, tem uma população 150 vezes maior que a de Seicheles (país menos populoso do grupo) e quase dez vezes maior que a do Lesoto (país continental menos populoso do grupo). Além disso, as experiências coloniais desses países também foram diversificadas e se aproximam da proporção do resto do continente: três deles foram colonizados pelo Reino Unido; três, pela França; um, por Portugal; e um, pela África do Sul. ${ }^{115}$

\footnotetext{
${ }^{114}$ Esta é, na verdade, uma realidade dos países insulares africanos. Dos cinco, apenas Comores teve conflitos não-estatais. Os outros quatro (Cabo Verde, Maurício, São Tomé e Príncipe e Seicheles) nunca tiveram nem conflitos civis nem conflitos menores.

115 A partir de 1884, a Namíbia foi um protetorado da Alemanha (Sudoeste Africano) e ficou sob o jugo dos alemães até a I Guerra Mundial, quando foi ocupada por forças do Reino Unido e da União SulAfricana. Esta última recebeu da Liga das Nações a tutela do Sudoeste Africano em 1921 e solicitou às Nações Unidas autorização para incorporar o território tutelado ao seu - o que foi negado. Em 1964, as Nações Unidas votaram por terminar a tutela do Sudoeste Africano exercida pela República da África do Sul, que desobedeceu a determinação e manteve a ocupação do território. A Namíbia tornou-se efetivamente independente apenas em 1990, após 69 anos de jugo sul-africano.
} 


\subsection{Avaliando a causalidade convencional}

Face tal quadro de heterogeneidade dentro do grupo e visto que este é tão heterogêneo quanto o grupo de países analisados no capítulo anterior, a pesquisa sobre as causas da paz nestes oito países seguirá os mesmos passos. Serão abordados primeiro fatores como a qualidade da vizinhança desses países, os regimes políticos que eles tiveram ao longo de sua história, sua composição demográfica e étnica e também o papel dos recursos naturais em sua economia. Analisando estes fatores como causas da guerra ou da paz, verificou-se no capítulo anterior que nenhum deles pode ter sido um fator estabilizador nos treze PMDs que nunca passaram por conflitos. Se tal quadro for semelhante para estes oito países, o debate sobre as causas de sua paz será restrito à autoridade estatal e ao desenvolvimento.

Figura 6 - Não-PMDs da África que não tiveram guerras civis, conflitos menores ou conflitos não-estatais

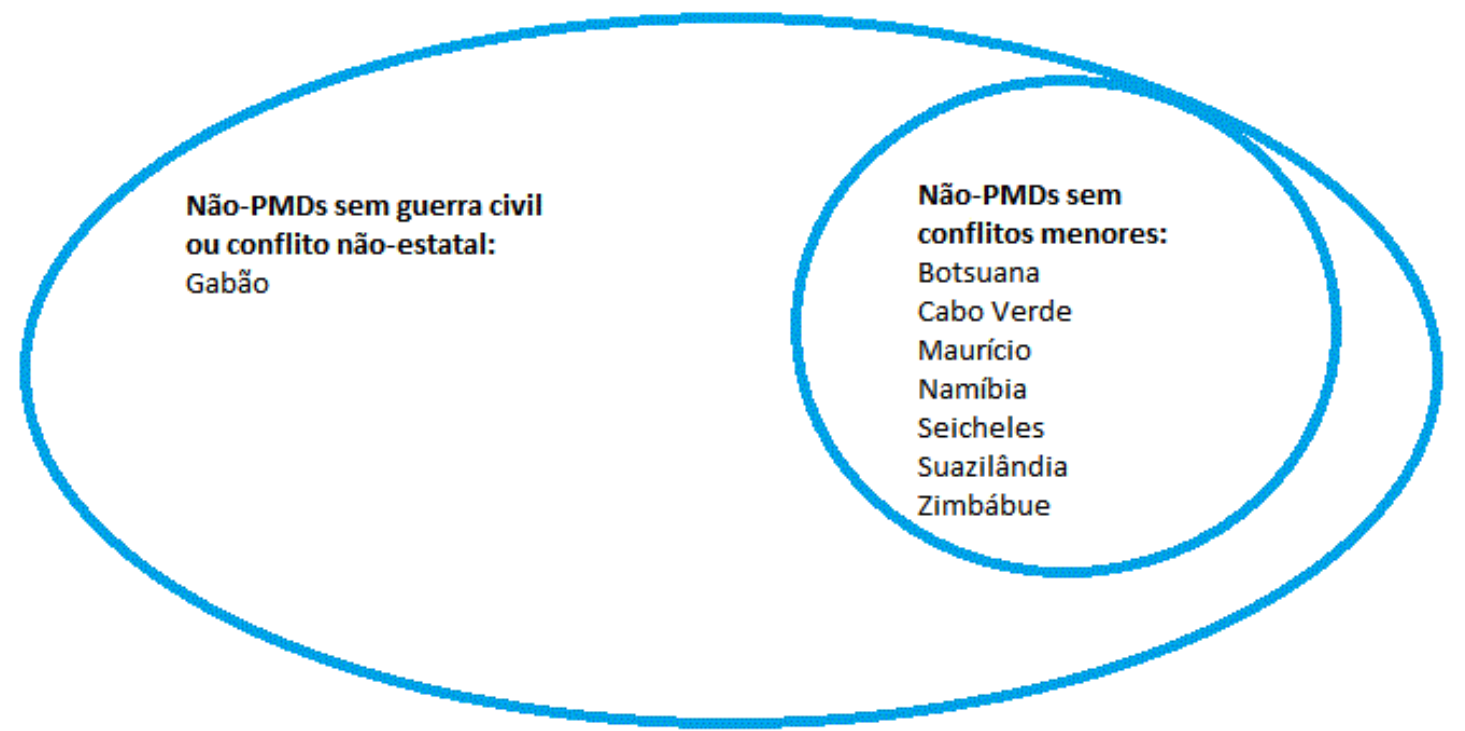

Fonte: Uppsala Conflict Data Program (2016), elaboração própria.

Assim como no capítulo anterior, a hipótese da má vizinhança não parece encontrar respaldo neste grupo de países. Em média, quase dois terços dos Estados com quem estes fazem fronteiras passam ou passaram por guerras civis ou conflitos nãoestatais. Em um extremo, pode-se dizer que a Suazilândia é o país com a pior vizinhança deste grupo, uma vez que ambos os países com quem faz fronteira (África do Sul e Moçambique) tiveram guerras civis e, para piorar, concomitantemente entre 1981 e 1983 e 1986 e 1988. Para piorar, a violência (seja como guerra civil ou conflito menor) esteve presente em ambos no período que vai desde 1977 a 1988. No outro extremo, apenas um dos quatro países com quem Botsuana faz fronteira passaram por guerra civil ou conflito 
menor desde a independência. ${ }^{116}$ Além desses, o caso do Gabão é interessante: ele é único país do grupo que teve conflitos menores e dois de seus três vizinhos tiveram guerra civil ou conflitos não-estatais (República do Congo e Camarões). Outro ponto que chama a atenção sobre a vizinhança destes países é o fato de que quatro deles (Namíbia, Botsuana, Zimbábue e Suazilândia) encontram-se na África Austral, uma região historicamente conhecida pela luta contra o apartheid na África do Sul e pela intervenção desta, a partir da Namíbia, na guerra civil de Angola. Nela, a questão da concomitância dos conflitos faz sentido: África do Sul, Angola e Moçambique estiveram em guerra civil ou conflitos menores ao mesmo tempo por onze anos. Além disso, chama a atenção a sua proximidade com a Zâmbia e o Maláui, outros dois países que nunca passaram sequer por conflitos menores e o fato de que três deles também foram colonizados pelo Reino Unido. Se isto influenciou de alguma forma a estabilidade neles será visto mais a frente.

A questão dos regimes políticos também não é conclusiva quando se analisa sete destes oito Estados, mas indica um cenário mais favorável à estabilidade das instituições políticas do que o grupo de países do capítulo anterior. ${ }^{117}$ Contando-se cada ano desde as independências e cada país como algo distinto, estes países eram democracias ou autocracias em cerca de 58,4\% do tempo de independência. Além disso, seguindo-se o mesmo critério, os tais países foram democracias em cerca de 48,9\% do tempo. Alguns países são responsáveis por esses valores altos: Botsuana, Namíbia e Maurício passaram todo o tempo desde suas independências baixo regimes democráticos. Por outro lado, a Suazilândia também passou apenas cinco primeiros dos 48 anos de sua história independente baixo um regime político que não era nem uma democracia nem uma autocracia. Ao contrário daqueles três mencionados há pouco, o país tornou-se uma autocracia e assim o é desde então. Por outro lado, o Gabão passou o tempo todo de sua história independente sem ser nem uma democracia nem uma autocracia. ${ }^{118}$

A análise sobre este grupo de Estados poderia favorecer o argumento de que as guerras civis tenderam a ocorrer onde não há nem uma democracia bem estabelecida ou uma ditadura. No entanto, o fato de o Zimbábue também nunca ter passado nem mesmo

\footnotetext{
${ }^{116}$ De certo modo, esta não foi sempre a realidade de Botsuana. O país tem longa fronteira com a Namíbia, que esteve sobre tutela da África do Sul até 1964 e depois ficara ocupada pela mesma. Até 1990, a SWAPO lutou pela independência do Sudoeste Africano. Durante esse período, a Namíbia foi também palco de conflito que poderia ter afetado negativamente Botsuana.

${ }^{117}$ Seicheles não foi incluído na classificação do Center for Systemic Peace (2016).

${ }^{118}$ Center for Systemic Peace (2016)
} 
por conflitos menores desafia tal raciocínio. O país governado por Robert Mugabe nunca foi e definitivamente não é uma democracia, mas foi uma autocracia por apenas doze anos (1987-1999) desde sua independência em 1980. Ou seja, o país passou quase dois terços de sua história baixo um regime que não era nem uma autocracia nem uma democracia. Além disso, a comparação dele com os treze PMDs analisados no capítulo anterior leva a desacreditar que esta tenha sido a razão para a paz nesses países. Afinal, os dois grupos tiveram o mesmo resultado (não tiveram guerras civis) mesmo com proporções diferentes na ocorrência de regimes democráticos ou autocráticos.

Figura 7 - Má vizinhança: não-PMDs pacíficos e seus vizinhos

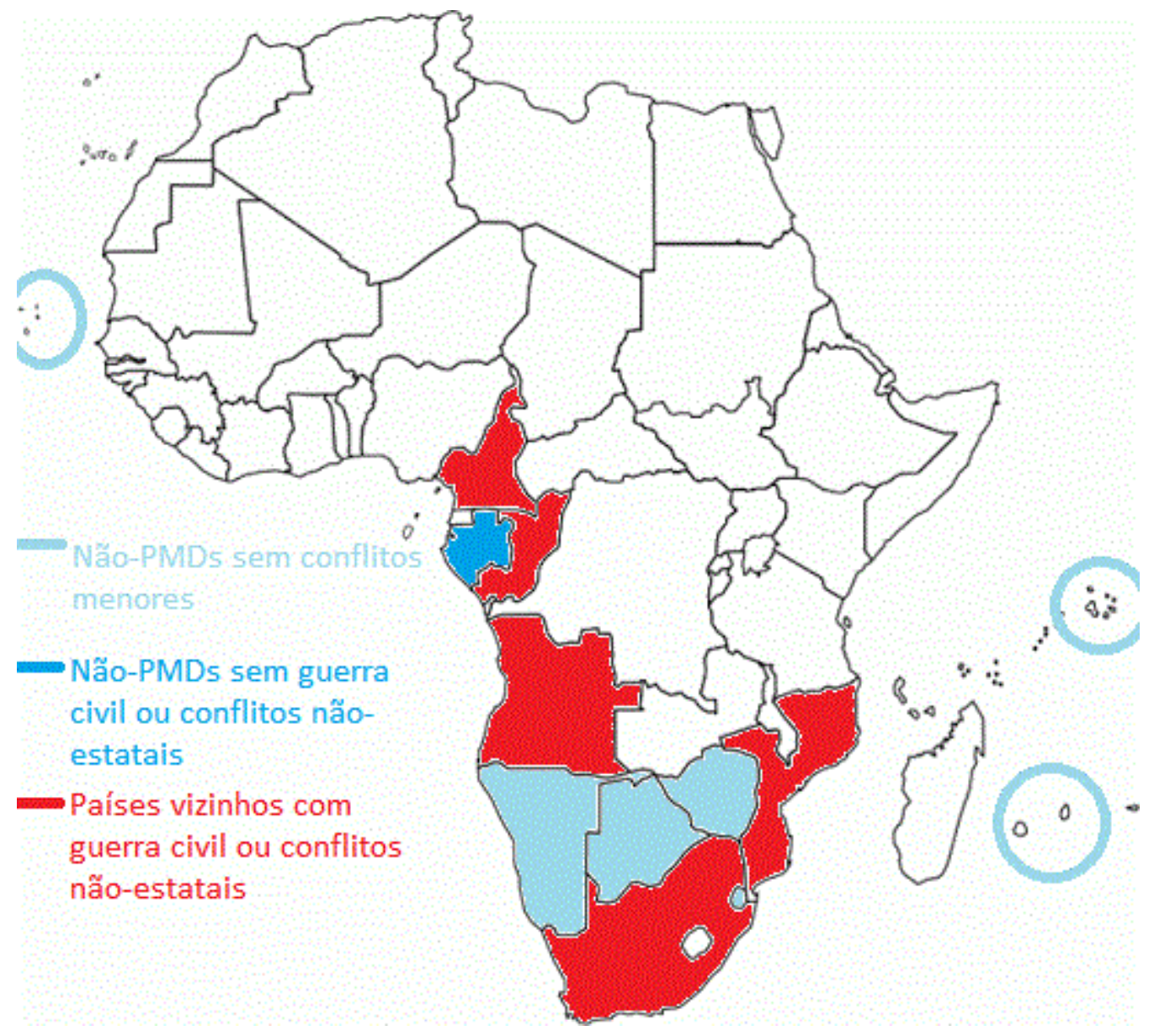

Fonte: Uppsala Conflict Data Program (2016), elaboração própria.

A questão étnica tampouco parece apontar para o motivo pelo qual a paz prevaleceu em tais países. A comparação com Libéria e Ruanda nos três indicadores utilizados para tanto, tal como feita no capítulo anterior, demonstra que há resultados diferentes para fatores causais semelhantes. Botsuana e Maurício, por exemplo, têm assim, como a Libéria, bastantes grupos étnicos politicamente relevantes, mas não apenas 
não tiveram guerras civis ou conflitos não-estatais como também não chegaram a ter nem mesmo conflitos menores. Situação parecida é encontrada na análise do fracionamento étnico dos países em questão. Maurício e Libéria apresentam valores bastante parecidos neste sentido assim como Gabão e Ruanda. Os primeiros de ambos os pares, contudo, não conheceram a guerra civil em sua história independente. $O$ único indicador aqui que pode jogar alguma luz sobre a questão parece ser a legitimidade horizontal. Apesar de Botsuana e Ruanda terem o mesmo valor neste ponto, mas terem tido sortes bastante distintas no que concerne à paz e à guerra, não se pode fechar os olhos para o fato de que os países que obtiveram pontuação máxima neste quesito não passaram por conflitos menores, independentemente se PMD ou não. Isto é, Cabo Verde, Maurício e Seicheles podem ter recebido uma contribuição bastante importante neste quesito. O motivo para isto é o mesmo para São Tomé e Príncipe (um dos PMDs do capítulo anterior): nenhum deles tinha assentamento humano prévio e assim suas instituições políticas foram criadas junto com o povoamento de suas ilhas, fazendo com que não houvesse sobreposição de entidades políticas e que as populações não conhecessem nenhuma outra instituição política que não as que estavam sendo criadas.

A comparação das médias desses países com os dos PMDs pacíficos também não parece ajudar muito para a compreensão da origem da paz e da guerra diretamente, mas sim chamam a atenção pelo fato de que podem ter influenciado nos níveis de desenvolvimento de tais países. Primeiro, tal como concluiu Englebert (2000b), Estados com legitimidade vertical e maior legitimidade horizontal têm maiores níveis de desenvolvimento. Apenas quatro países pacíficos da África Subsaariana têm legitimidade vertical segundo o autor: Cabo Verde, Maurício, São Tomé e Príncipe e Seicheles. Deles, apenas São Tomé e Príncipe está entre os PMDs. Tais países são também os únicos que atingiram o maior valor em legitimidade horizontal. Além disso, a legitimidade média dos PMDs pacíficos é menor que a dos não-PMDs pacíficos $(0,545$ e 0,727 respectivamente). $\mathrm{O}$ resultado também se mantém ao analisar o valor médio apenas daqueles que não tiveram nem mesmo conflitos menores: 0,558 e 0,862, respectivamente. Ademais, o autor também afirmou que os Estados menos legítimos eram também aqueles que mais tiveram conflitos intra-estatais. Ou seja, ele não descartou o papel do desenvolvimento e da legitimidade estatal na pacificação dos Estados na África Subsaariana. 
Segundo, o fracionamento étnico dos países também apresenta diferenças de acordo com a categoria de desenvolvimento dos países em questão. No geral, os nãoPMDs pacíficos são menos fracionados do que os PMDs pacíficos $(0,295$ e 0,354 respectivamente). Ao excluir os países que tiveram conflitos menores, a diferença entre os dois grupos aumenta 3,5 vezes e os valores dos grupos seguem direções opostas: os não-PMDs pacíficos ficam ainda menos fracionados $(0,260)$ enquanto os PMDs pacíficos ficam ainda mais fracionados $(0,468)$. Isto induz a se pensar em uma relação inversa entre o fracionamento étnico da população e o desenvolvimento, o que contradiz o achado exposto no parágrafo anterior. Por outro lado, tais números poderiam corroborar o argumento de quando se trata de guerras étnicas, o problema não é ter muitas etnias, mas poucas. Não à toa, os países pacíficos da África Subsaariana que não tiveram guerra civil ou conflitos não-estatais são mais fracionados do que aqueles que não tiveram nem mesmo conflitos menores. Inclusive, quando se foca nos não-PMDs, essa realidade acentua-se, especialmente se for levado em consideração a quantidade de grupos étnicos politicamente relevantes (EPR), apesar de não haver correlação entre tal quantidade e o fracionamento étnico da população (PREG). Além disso, a quantidade de grupos étnicos nesses países é ainda mais potencializada, tal como mostram a Namíbia e Botsuana.

Tabela 7 - Questão étnica nos não-PMDs que não passaram por guerras civil e Ruanda e Libéria

\begin{tabular}{lccc}
\hline País & EPR & PREG & LEGITH \\
\hline Gabão & Sem Guerra Civil & & \\
& 6 & 0,21 & 0,326 \\
& Sem Conflitos & & \\
Benores & & 0,904 \\
Cabo Verde & 10 & 0,00 & 1,000 \\
Maurício & N/A & N/A & 1,000 \\
Namíbia & 9 & 0,60 & 0,381 \\
Seicheles & 12 & 0,55 & 1,000 \\
Suazilândia & N/A & 0,00 & 1,000 \\
Zimbábue & 1 & 0,00 & 0,750 \\
\hline Libéria & 7 & 0,41 & $\mathbf{0 , 5 6 4}$ \\
Ruanda & $\mathbf{8}$ & $\mathbf{0 , 6 2}$ & $\mathbf{0 , 9 9 0}$ \\
\hline
\end{tabular}

Fonte: Cederman, Min e Wimmer (2009), Posner (2004), Englebert (2000b), elaboração própria.

A partir das três ferramentas usadas para medir o fracionamento étnico dos Estados, percebeu-se uma diferença interessante entre os não-PMDs pacíficos e os PMDs pacíficos, sendo os primeiros menos fracionados. Por outro lado, não foi possível completar de forma consensual a tríplice relação entre fracionamento étnico, 
desenvolvimento e ocorrência de conflitos menores. Utilizando-se o LEGITH, chegou-se a uma relação inversa entre legitimidade horizontal e conflitos e direta entre e a primeira e o desenvolvimento, corroborando assim com a tese que vincula desenvolvimento e segurança. Usando o PREG/EPR, nota-se que o menor fracionamento étnico de um Estado também leva a maiores níveis de desenvolvimento.

A ausência de recursos naturais em tais países e seu papel nas economias deles tampouco podem explicar o fato destes oito países não terem passado por guerras civis ou conflitos não-estatais. O primeiro motivo é que Botsuana e Namíbia e Gabão são países ricos em recursos naturais e são exportadores de minérios e de petróleo. Se tal condição pode ter levado outros Estados à guerra, estes não sucumbiram a ela nem entraram em colapso. Inversamente, e talvez diretamente relacionado ao maior nível de desenvolvimento destes Estados, está o fato de que no geral eles não são dependentes das exportações de recursos minerais. Como era de se esperar, Botsuana e Gabão tem suas exportações concentradas nos recursos nos quais são ricos: $80,9 \%$ das exportações do primeiro é de diamantes e $81,3 \%$ das exportações do segundo é de petróleo. A Namíbia, o outro país rico em recursos naturais deste grupo, não tem uma economia dependente de tais produtos, apesar de estes ocuparem uma importante parcela de suas exportações. ${ }^{119}$ Além desses, os recursos naturais representam importante parcela das exportações apenas em Cabo Verde. ${ }^{120}$

Diferentemente dos PMDs que não passaram por guerra civil ou conflitos nãoestatais, alguns fatores que costumam ser usados para explicar o colapso estatal e a eclosão de guerras civis na África ou estão ausentes ou não são fortes o bastante para explicar a paz nestes oito países. Como foi visto, o único dos quatro fatores que realmente não se pode alegar para sua realidade pacífica foi a questão da vizinhança. No geral, eles estavam em regiões onde sangrentas guerras civis aconteceram sendo que, em alguns casos, concomitantemente. No entanto, a situação destes países no que concerne os regimes políticos, das etnias e dos recursos naturais não parecem ter força para contradizer de forma significante e assim para invalidar as hipóteses comumente levantadas.

119 Os diamantes representaram 28\% das exportações namibianas em 2014 e o zinco, 13,7\% (African Economic Outlook, 2014).

${ }^{120}$ O petróleo representou 50,1\% das exportações de Cabo Verde em 2014 (African Economic Outlook, 2014). 
No geral, estes Estados raramente estiveram em regimes intermediários, que não eram nem democracias bem estabelecidas nem autocracias. Houve, inclusive, uma forte presença de regimes democráticos entre eles e o país que passou mais tempo em regimes intermediários foi também o único país que teve conflitos menores. Na questão das etnias, as medidas usadas para lidar com elas indicaram, por um lado, a falta de padrão e também a proximidade de alguns desses países com a realidade étnica de Libéria e Ruanda. As três ferramentas (EPR, PREG e LEGITH), porém, apontaram para uma relação inversa entre o fracionamento étnico de um país e seu desenvolvimento, mas não permitiram indicar tendências na mesma direção no que tange à relação destes com a ocorrência de conflitos intraestatais. Por fim, também com os recursos é difícil chegar a uma conclusão sobre a dependência dos Estados a eles e a ausência de conflitos. Ainda que Maurício, Seicheles, Suazilândia e Zimbábue não sejam ricos em recursos naturais e que tais produtos representem parcelas diminutas de suas exportações, o quadro é bastante diferente para a outra metade dos países deste grupo.

Pensando ainda nas causas da paz como a negação das causas da guerra, a única hipótese que não pode ser afastada pensando-se nestes oito países é a dos regimes políticos, isto é, aquela que afirma que democracias bem estabelecidas e autocracias são mais estáveis do que regimes políticos intermediários. Esses países passaram boa parte senão todo o tempo de sua história independente como democracias (destaque para Botsuana, Maurício e Namíbia que tiveram tal regime político desde o momento de suas independências) e o Gabão, único país que teve conflitos menores, foi justamente o que passou mais tempo em regimes intermediários. Estas constatações são interessantes por dois motivos: elas vão ao encontro de uma série de argumentos que vinculam a democracia ao desenvolvimento e à paz doméstica, ou seja, corroboram com a tese da Paz Liberal, mas também estão na esfera que mais se aproxima da questão da autoridade estatal.

A discussão a partir deste momento terá, portanto, o objetivo de avaliar se o papel que o maior nível de desenvolvimento e de autoridade estatal desempenham na estabilidade em tais países. Essa discussão sobre as causas da paz terá, necessariamente, que levar em consideração a possibilidade de que ambos sejam responsáveis por ela ou se apenas um deles (e neste caso, qual deles). Tal feita representa um esforço não apenas entre estabelecer uma causalidade entre um deles e a paz nestes Estados, mas também apontar para uma antecedência ontológica entre estabilidade e desenvolvimento. Afinal, 
tais Estados são estáveis porque têm mais desenvolvimento ou têm mais desenvolvimento porque são estáveis?

A resposta desta pergunta é mais importante do que se pode imaginar. Se a resposta for que a estabilidade precedeu ou é a causa do desenvolvimento, estes oito países endossarão o achado do capítulo anterior e assim corroborarão com o argumento apresentado na primeira parte desta obra de que o que realmente evita as guerras civis e o colapso estatal na África Subsaariana é a consolidação da autoridade estatal e não o desenvolvimento. Assim, será necessário também demonstrar como a autoridade estatal foi construída nesses Estados de modo a suprimir ou incorporar as fontes concorrentes de autoridade. Por outro lado, afirmar que o desenvolvimento é a causa da estabilidade nesses países pode indicar que a fusão entre desenvolvimento e segurança é devida e que ambos podem ter influenciado positivamente este grupo de países ou que tais países representam uma exceção à tese que desvincula desenvolvimento e segurança.

No geral, estes oito países estavam melhor que os demais do continente (pacíficos ou não) tanto em termos de autoridade quanto de desenvolvimento. No entanto, também neste grupo há um descompasso entre tais variáveis, uma vez que 40,6\% dos 128 casos (8 países e 16 anos) não estavam na mesma categoria. Este descompasso, contudo, é menor do que o dos PMDs que nunca passaram por guerra civil $(41,5 \%)$ e de toda a África Subsaariana (44\%). Apesar de serem bastante pequenas, essas diferenças não surpreendem principalmente quando se compara os dois grupos de países pacíficos. $\mathrm{O}$ principal motivo para que mais casos estivessem na mesma categoria entre os não-PMDs pacíficos do que entre os PMDs pacíficos é justamente que os primeiros tiveram entre 1996 e 2011 (e em toda a história também) melhores níveis de desenvolvimento.

O fato de os não-PMDs terem mais da metade de seus casos em categorias diferentes aponta para o fato de que também neles autoridade e desenvolvimento tiveram dinâmicas distintas e, por isso, sugere que pode haver uma antecedência ontológica e um sequenciamento entre eles tal como a regra da região. Além disso, os casos onde houve diferenças geralmente indicaram que a autoridade estava em níveis mais altos do que o desenvolvimento. A distribuição dos casos nas categorias em ambos os indicadores também demonstra melhores desempenhos naquela do que neste. Apesar de a categoria mais alta ter sido atingida apenas no desenvolvimento (Seicheles entre 2000 e 2001) e não ter sido atingida na autoridade, o inverso acontece com a categoria mais baixa (Zimbábue 
entre 2001 e 2011). Além disso, a distribuição dos casos nas categorias demonstra o melhor desempenho médio da autoridade também nestes países $(62,5 \%$ dos casos de autoridade estavam em B contra 48,4\% de desenvolvimento). A autoridade estatal de Botsuana, Cabo Verde e Namíbia estiveram o tempo todo em categoria melhor ou igual que o desenvolvimento. Em Maurício, Suazilândia e Seicheles, autoridade estatal e desenvolvimento estiveram praticamente o tempo todo na mesma categoria enquanto no Gabão e no Zimbábue, o desenvolvimento esteve quase sempre em situação melhor. ${ }^{121}$

Ainda comparando as evoluções desses países em autoridade e desenvolvimento, as correlações entre as duas variáveis também reforçam a ideia de que autoridade e desenvolvimento seguem caminhos distintos. Apenas Botsuana e Maurício apresentaram correlações positivas entre elas para o período entre 1996 e 2011. Contudo, nenhum dos países chegou a apresentar alta correlação entre elas (seja positiva ou negativa). O fato de todos os países deste grupo estarem mais desenvolvidos em 2011 do que em 1996 combinado com o fato de seis deles terem correlações negativas entre autoridade e desenvolvimento mostra que houve, no geral, um movimento de queda nos níveis da autoridade estatal em tais Estados. De fato, apenas, Botsuana, Maurício e Namíbia apresentaram tendências crescentes para autoridade estatal. Três casos aqui chamam a atenção.

O primeiro é que a autoridade estatal da Namíbia estava pior em 2011 do que em 1996, apesar da tendência crescente nesse período. Essa contradição se deve às fragilidades e à crise política que se instauraram no país entre 1996 e 2000. Durante a primeira década de independência do país, a consolidação das instituições democráticas fora desafiada pelo entendimento pré-democrático que os líderes da SWAPO mantinham. Ainda com mentalidade colonial e refletindo seus anseios para garantir a independência do país, o agora partido governista continua sendo intolerante a opiniões divergentes, inclusive (e principalmente) aquelas que questionassem o Estado namibiano. Foi neste sentido que a questão da Faixa de Caprivi escalou para uma importante crise política, quando um campo de treinamento Exército de Libertação de Caprivi (ELC) foi descoberto e destruído pelas Forças de Defesa da Namíbia (FDN) em 1998. No ano seguinte, a

\footnotetext{
${ }^{121}$ O desenvolvimento de Seicheles atingiu a categoria A em 2000 e 2001 . Todo o restante do período, foi $\mathrm{B}$, mesma categoria para sua autoridade. A autoridade do Zimbábue regrediu da categoria C para a D em 2000 e ficou lá até o fim do período analisado. Seu desenvolvimento esteve tempo todo na categoria C, mesmo com a crise monetária que assolou o país no ano 2008.
} 
situação se deteriorou quando o grupo separatista atacou prédios do governo central na capital da região, chegando a ocupar e assumir o controle da rádio estatal. $\mathrm{O}$ governo retomou o controle da província após decretar estado de emergência na região, que foi muito criticado uma vez que permitiu várias violações de direitos humanos, como detenções arbitrárias (Melber, 2009; 2010; 2011). ${ }^{122}$ A crise afetou a autoridade estatal de tal modo que o país atingiu seu valor mais baixo para o período no ano 2000 e que, apesar da recuperação desde então, não atingiu o mesmo patamar que estava no início do período.

O segundo caso é o Gabão, que apresentou um quadro exatamente contrário ao da Namíbia no mesmo período: tendência decrescente da autoridade estatal entre 1996 e 2011, mas situação melhor no fim do período. A crise pela qual o país passou entre 2001 e 2006 foi tão forte que fez com que fosse do auge para o antauge da autoridade estatal no período, que foi marcado por forte disputa política e fraudes eleitorais. Após as eleições presidenciais de 1998 que elegeram Omar Bongo para seu sexto mandato como presidente do país, o país entrou em uma espiral política que foi minando suas instituições. De fato, o processo resumiu-se em adequá-las para garantir a Bongo o controle total da Assembleia Nacional e também a reeleição a mandatos ilimitados. Paradoxalmente, foi justamente o sucesso de tal processo que culminou na decadência gabonesa. As eleições presidenciais de 1998 já haviam sido questionadas pela oposição derrotada que reclamava de uma série de irregularidades, que foram confirmadas por observadores internacionais. No entanto, segundo os mesmos, estas não haviam sido suficientes para alterar o resultado da votação. Em 2001, Omar Bongo ampliou seu poder quando seu partido conquistou 86 das 120 cadeiras no parlamento em eleições com denúncias de fraude e boicotadas por partidos da oposição. Foi essa base parlamentar que permitiu a aprovação da emenda constitucional que removeu o limite máximo de dois mandatos seguidos para presidente do país - não sem protestos. Mais uma vez, em 2005, Bongo se apresentou às eleições presidenciais para concorrer ao seu sexto mandato seguido. O pleito, como esperado, não foi sem problemas. Adversários reclamaram de

\footnotetext{
${ }^{122} \mathrm{O}$ grupo pivô da crise era liderado por um velho conhecido da SWAPO. Mushake Muyongo era dissidente do partido desde os anos no exílio em Angola e foi derrotado por Sam Nujoma nas primeiras eleições presidenciais do país em 1994. Foi expulso da ADT, partido que presidiu por oito anos e pelo qual concorreu às eleições, por apoiar a causa separatista de Caprivi, sua região natal. Tal apoio não era apenas ideológico: ele era líder tradicional e membro da família real do grupo étnico Mafwe.
} 
irregularidades e houve também violência após o anúncio da vitória. O clima de tensão alastrou-se até as eleições legislativas do ano seguinte, quando vários assentos no parlamento foram contestados na Corte Suprema do país com base em irregularidades durante a votação. A Corte validou os resultados e o segundo turno das eleições legislativas confirmaram a maioria absoluta do Partido Democrático Gabonês (PDG) na Assembleia Nacional. Foi a partir do restabelecimento de tal controle que a autoridade estatal retomou seu crescimento no país. ${ }^{123}$

O terceiro é o Zimbábue, que apresentou deterioração significativa dos níveis de autoridade entre 1996 e 2011, chegando a seu nível mais baixo em 2009, quando uma turbulência política relacionada às eleições presidenciais se combinou com uma crise de hiperinflação que literalmente acabou com a moeda local. Desde o ano 2000, o país enfrentava uma crise econômica profunda. A partir de 2003, a diferença entre a taxa de câmbio oficial e do mercado negro aprofundaram a falta de moeda estrangeira que lastreava o dólar zimbabuano. A consequente e inevitável des valorização da moeda gerou um processo inflacionário que atingiu seu pico em 2008 quando o governo admitiu que a taxa de inflação havia atingido pelo menos impressionantes $231.000 .000 \%$ enquanto o Instituto Cato, think tank americano que avalia a economia de diversos países do mundo, afirmava que havia chegado à impressionante casa do sextilhões, isto é, atingindo a marca de aproximadamente 89.000.000.000.000.000.000.000\%. ${ }^{124}$ Em 2009, o governo do país decidiu parar de emitir e abandonar a moeda local e dolarizar a economia, o que permitiu o crescimento positivo do PIB pela primeira vez em uma década.

Foi justamente no começo de 2008, ano do auge da crise de hiperinflação, que aconteceram as problemáticas eleições presidenciais no país. Robert Mugabe, presidente do país desde o fim do colonialismo em 1980, apresentou-se candidato à reeleição pela ZANU-PF enquanto Morgan Tsvangirai, do Movimento para Mudança Democrática (MDC), apresentou-se como candidato concorrente. Estas eleições seriam as primeiras da história do país em que um candidato necessitaria a maioria dos votos para se eleger. Com o contexto da crise econômica, esperava-se resultados apertados e até mesmo uma eventual derrota de Mugabe - o que aconteceu no primeiro turno em março daquele ano.

\footnotetext{
${ }^{123}$ O Gabão é o único país analisado neste capítulo que teve conflitos menores. Estes, no entanto, não aconteceram durante a onda de violência que assolou o país após as eleições presidenciais de 2005, mas sim em fevereiro de 1964 quando o presidente Leon M'Ba sofreu uma tentativa de golpe de Estado. 124 "Inflação do Zimbábue pode ter superado 89 sextilhões por cento, diz instituto" (2009).
} 
Ao contrário do primeiro turno, a campanha para o segundo foi bastante problemática. A oposição queixou-se de intimidação e anunciava que uma série de fraudes estavam sendo armadas para manter Mugabe no poder e a poucos dias do pleito, Tsvangirai anunciou que estava se retirando das eleições devido à violência política e à falta de transparência e idoneidade do processo. Seu nome não foi retirado das cédulas e Mugabe obteve vitória esmagadora, apesar da derrota e consequente recuo de seu partido nas eleições para a Assembleia Nacional. Pela primeira vez desde a independência do Zimbábue, a ZANUPF não tinha mais a maioria dos assentos no órgão legislativo. O impasse político que se instalou no país só foi resolvido meses depois com mediação da Comunidade para o Desenvolvimento da África Austral (SADC) e com a criação de um acordo de partilha de poder que instituiu Tsvangirai como primeiro-ministro do Zimbábue.

De todo modo, os oito não-PMDs que não passaram por guerra civil ou conflitos não-estatais apresentam semelhança importante entre eles e também com os PMDs pacíficos. Assim como no segundo grupo, estes também têm desempenho superior em garantir a ausência da violência política e terrorismo do que na eficácia da governança e na nomocracia. Entre 1996 e 2011, três em cada quatro casos dos não-PMDs pacíficos estavam melhor naquele indicador do que nesses. Este é um indicativo importante de que medidas que garantam a ordem e a segurança bem como o respaldo que a população dá à presença da instituição e dos governantes fazem com que os atores dispostos a competir para ocupar postos na administração e gestão estatal o façam por meio das regras e das instituições e não contra elas. Além disso, esses oito Estados aparecem bastante na categoria B nos três indicadores que compõem a variável autoridade. No que diz respeito à efetividade da governança e à nomocracia, eles têm desempenho bastante superior do que os PMDs pacíficos: $60 \%$ de seus casos estão na categoria $\mathrm{B}$, contra apenas $2 \%$ dos casos dos PMDs pacíficos.

Botsuana é um país importante neste sentido. Uma série de autores e de relatórios indicam que seu sucesso econômico e desenvolvimentista se deve não apenas às políticas macroeconômicas tomadas, mas também às instituições do país que historicamente favorecem um ambiente de investimento e desenvolvimento econômico. Desde sua independência em 1966 até 2014, o país teve a terceira economia que mais cresceu no mundo (5,9\% ao ano) segundo o Banco Mundial (2015) e, no contexto da África Subsaariana, teve o quinto melhor desempenho em desenvolvimento entre 1990 e 
2011. ${ }^{125}$ Tal desempenho foi financiado pela exploração de diamantes, que teve seu primeiro boom logo após a independência, e com objetivos de longo prazo conseguiu evitar que efeitos negativos comuns a países ricos em recursos naturais afetassem sua economia. ${ }^{126}$ Assim, Botsuana tornou-se um exemplo de que a combinação de boas instituições políticas e boas políticas econômicas promovem o crescimento e o desenvolvimento econômico mesmo financiado por recursos naturais. Desde a independência, esses recursos são constantemente investidos em infraestrutura hídrica e de transportes, educação e saúde. Tais áreas, contudo, ainda são bastante dependentes da renda proveniente da exportação dos diamantes (Acemoglu, Johnson, \& Robinson, 2003; Mbabazi \& Taylor, 2005; Beaulier \& Subrick, 2006; Lewin, 2011). ${ }^{127}$

Botsuana serve de exemplo de como esse grupo de países não necessitou sacrificar o desenvolvimento para garantir a estabilidade. Ainda que hajam correlações negativas entre autoridade e desenvolvimento neles, os níveis em que ambos indicadores se encontram mostram que tais países realmente têm desempenho bastante superior que seus congêneres da África Subsaariana, inclusive aqueles que não passaram por guerras civis ou conflitos não-estatais. Por mais que o neopatrimonialismo seja uma característica forte também nesses não-PMDs pacíficos (o que pode impedi-los de almejar níveis melhores de desenvolvimento), ele não parece ser determinante ou ter atingido condição sine qua non para a autoridade estatal e a estabilidade do regime em tais países. Tal situação leva a um questionamento importante sobre a relação entre autoridade e desenvolvimento. Se há países que sacrificam o desenvolvimento para garantir a autoridade estatal e há também componentes desta que favorecem o desenvolvimento, como dissociá-los e assim estabelecer causalidade entre autoridade estatal e ausência de guerra civil e conflitos nãoestatais?

A questão é que a grande diferença entre os não-PMDs que nunca passaram por guerras civis ou conflitos não-estatais e os PMDs que também não sucumbiram a tais fenômenos é justamente o desenvolvimento, e não a autoridade. Enquanto o primeiro

\footnotetext{
${ }^{125}$ De acordo com a definição de desenvolvimento usada neste estudo. O país está atrás apenas da Guiné Equatorial, Maurício, Gana e Cabo Verde.

${ }^{126}$ Dentre os efeitos negativos mais comuns está a chamada doença holandesa, "uma falha de mercado originada na existência de recursos humanos ou naturais baratos e abundantes que mantêm a moeda nacional sobrevalorizada por período de tempo indeterminado, fazendo assim não lucrativa a produção de bens que usam tecnologia" (Bresser-Pereira, 2008).

${ }^{127} \mathrm{O}$ sucesso das políticas desenvolvimentistas de Botsuana é questionado por autores como Maipose (2008) pelo fato de não terem conseguido superar a pobreza.
} 
grupo teve desenvolvimento médio entre 1996 e 2011 cerca de 55\% maior que o segundo, a diferença no valor médio de autoridade não passou de $31 \%$. Mais especificamente, a diferença entre eles no componente ausência de violência política e terrorismo foi de $22 \%$, a menor de todas. O fato de os não-PMDs em questão estarem melhores que os PMDs tanto em desenvolvimento quanto em autoridade demonstra que as teorias de sequenciamento que privilegiam a autoridade e tratem o desenvolvimento como possível consequência têm respaldo uma vez que o Estado consegue emancipar suficientemente suas instituições da sociedade de modo a diminuir ou até mesmo erradicar o neopatrimonialismo e as redes clientelistas que se ocupam da administração pública para atingir seus objetivos privados. ${ }^{128}$ Assim, os governantes não são obrigados a sacrificar o desenvolvimento do Estado distribuindo cargos públicos a atores aliados incapacitados de ocupá-los. Tais atores teriam espaço suficiente na iniciativa privada para conseguir a rentabilidade que desejam.

Assim, visto que o desenvolvimento pode ser tanto sacrificado em detrimento da construção da autoridade estatal como também ser uma consequência de determinadas políticas derivadas da autoridade, nota-se mais uma vez que não apenas estas duas variáveis podem viver dinâmicas distintas como também aquela pode variar em função desta e dada esta predominância da autoridade estatal, os mesmos testes levados a cabo no capítulo anterior serão feitos neste. De todo modo, é importante ressaltar que a diferença entre as médias dos dois grupos em autoridade estatal e na ausência de violência política e terrorismo não é significante, o que mostra que estes dois grupos de países são bastante semelhantes no que diz respeito a elas. ${ }^{129}$ Se os resultados relativos aos oito nãoPMDs que nunca passaram por guerra civil ou conflitos não-estatais continuarem a ser semelhantes em alguma medida aos dos trezes PMDs do capítulo anterior, poder-se-á afirmar que a causa da paz nestes países é justamente consequência da autoridade estatal.

\subsection{Continuidade das civilizações, geografia política e legitimidade estatal}

O primeiro fator a se pôr em prova é a parcela da população que acredita que "é importante obedecer ao governo no poder independentemente de para quem você votou". Como dito anteriormente, é de se esperar que uma parte menor da população concorde com tal frase em situações de fraca eficácia da governança e nomocracia. No entanto,

\footnotetext{
${ }^{128}$ O valor médio de desenvolvimento dos PMDs entre 1996 e 2011 excluiu a Eritreia e São Tomé e Príncipe, uma vez que tais dados não estavam disponíveis.

${ }^{129}$ A diferença entre as médias não é significante para os níveis de confiança de $99 \%$.
} 
neste grupo de países a situação se mostrou diferente nas três rodadas de pesquisa feitas. Em todas elas, o total de respondentes dos não-PMDs pacíficos que concordaram ou concordaram fortemente com tal afirmação foi inferior ao total dos PMDs pacíficos e nas duas primeiras rodadas de pesquisa, a diferença foi estatisticamente significante. ${ }^{130}$ Isto mostra uma interessante tendência de convergência entre os dois grupos de países. O curioso, no entanto, é que foi justamente nos países com melhor desempenho em eficácia da governança e nomocracia que se assistiu o aumento na quantidade de respondentes que concordava com tal afirmação. Este movimento de convergência aponta para o fortalecimento da estrutura do Estado perante a percepção de seus agentes políticos e cidadãos. Afirmar obediência ao governo independentemente se ele teve ou não o voto do cidadão significa tanto que o agente não vê vantagens ou possibilidade de sucesso em tentar aceder ao poder ilegalmente quanto que a população aceita voluntariamente cumprir com a legislação ou regulação criadas, independentemente de concordar com elas.

Tabela 8 - Obediência ao governo, independentemente de para quem se votou

\begin{tabular}{llll}
\hline País & $\mathbf{2 0 0 5 - 2 0 0 6}$ & $\mathbf{2 0 1 1 - 2 0 1 3}$ & $\mathbf{2 0 1 4 - 2 0 1 5}$ \\
\hline Gabão & Sem guerra civil & & \\
& & & \\
& $\begin{array}{l}\text { Sem conflitos } \\
\text { menores }\end{array}$ & & \\
Botsuana & $89,5 \%$ & $92,2 \%$ & $84,5 \%$ \\
Cabo Verde & $86,1 \%$ & $85,0 \%$ & $89,7 \%$ \\
Maurício & & $90,2 \%$ & $90,0 \%$ \\
Namíbia & $67,9 \%$ & $69,9 \%$ & $83,5 \%$ \\
Seicheles & & & \\
Suazilândia & & $88,3 \%$ & $91,2 \%$ \\
Zimbábue & $83,6 \%$ & $87,9 \%$ & $89,9 \%$ \\
\hline Total & $\mathbf{8 1 , 6 \%}$ & $\mathbf{8 5 , 9 \%}$ & $\mathbf{8 8 , 2 \%}$ \\
\hline
\end{tabular}

Fonte: Afrobarometer (2015), elaboração própria.

A grande responsável por esse processo de convergência é a Namíbia, cujos resultados alteraram-se e a parcela da população que concorda em obedecer ao governo cresceu de maneira significativa. Os baixos resultados iniciais do país é que chamam a atenção, afinal a Namíbia apresentou índices altos de autoridade estatal desde 1996, apenas seis anos após sua independência. No entanto, talvez seja justamente essa proximidade com a independência e o passado colonial que possa ter gerado desconfiança

\footnotetext{
${ }^{130}$ A significância estatística foi calculada para nível de confiança de $99 \%$. A diferença não foi significante para níveis de confiança de $90 \%, 95 \%$ e $99 \%$ apenas para a rodada de pesquisa mais recente $(2014 / 15)$.
} 
e receio por parte da população em obedecer às determinações do governo. Uma comparação da Namíbia com a África do Sul e com o Zimbábue pode ajudar bastante a compreender tal diferença. Tais países são comparáveis devido a três semelhanças importantes: 1- todos tiveram regimes de segregação racial durante sua história; 2- a luta armada foi o meio que pôs termo a tais regimes; e 3-os grupos que promoveram a luta armada transformaram-se em partidos políticos e governam esses países desde então. ${ }^{131}$ Nesta questão, a África do Sul também apresentou parcela menor de respondentes que concordavam com a frase proposta pela pesquisa, mas ficava inicialmente em um estágio intermediário entre a Namíbia e o Zimbábue. ${ }^{132}$ Além disso, o significado das diferenças das proporções nestes países indica uma tendência de convergência entre a Namíbia e o Zimbábue e divergência entre a África do Sul e os outros dois países.

Um dos motivos que explica essas tendências é a força da ruptura com o status quo promovido pelos regimes de segregação racial que existiram nesses países. Primeiro, a semelhança inicial entre África do Sul e Namíbia em muito se explica devido ao fato que a primeira ocupou a segunda por setenta anos e implementou nela também o regime do apartheid que, entre outras coisas, impedia o acesso da população negra às terras mais férteis. Igualmente, um regime semelhante esteve vigente na Rodésia até que a ZANUPF logrou pôr fim ao colonialismo, libertando o Zimbábue em 1980. O que gerou a diferença inicial entre eles, no entanto, foi o nível de ruptura com a ordem segregacionista. Apesar da diferença de tempo entre o fim de tais regimes em cada um desses países e a primeira rodada de pesquisa de opinião, não se pode subestimar os efeitos de rupturas parciais no reconhecimento da autoridade governamental e estatal. Na África do Sul e na Namíbia questiona-se ainda hoje status das terras e da ordem econômica vigente, ao passo que no Zimbábue as terras que pertencem à população branca foram em boa parte expropriadas. Assim, tanto na África do Sul quanto na Namíbia, pode-se afirmar que há certa desconfiança de parte significativa da população negra sobre as decisões que o governo pode tomar e de sua real capacidade ou vontade de mudar tal situação. ${ }^{133}$

\footnotetext{
${ }^{131}$ É importante ressaltar que a luta armada na Namíbia e no Zimbábue ocorreram antes de suas independências, ao contrário da África do Sul.

${ }^{132}$ Foram entrevistadas cerca de 2400 pessoas na África do Sul em cada uma das três rodadas de pesquisa (2005-06, 2011-13 e 2014-15). Em ordem cronológica, 77,9\%, 77,1\% e 78,4\% dos respondentes disseram concordar em obedecer ao governo independentemente de para quem eles votaram.

${ }^{133} \mathrm{O}$ apartheid promovido pela África do Sul na Namíbia deixou marcas que estão presentes até hoje. Em junho de 2011, a revista New African publicou artigo intitulado The trouble with Namibia no qual apresentava as consequências do apartheid naquele país: $90 \%$ das terras estavam sob a posse da população
} 
Um segundo motivo a se destacar é o fato que - como já dito - o governo da Namíbia manteve por muito tempo uma mentalidade pré-democrática e de libertação nacional mesmo após a independência, o que pode ter gerado desconfiança principalmente de sua população branca. Mesmo tendo mantido parte importante do status quo, principalmente no que tange à propriedade privada, o governo da SWAPO ainda é visto com desconfiança por parte da população branca que perdeu muitos privilégios com a independência do país. $\mathrm{O}$ acesso a cargos públicos ficou mais difícil para os brancos e a política de reforma agrária começou a desafiar muitos dos interesses dessa elite racial. Desse modo, o governo do país começou a dar sinais de distanciamento e da desconstrução do legado apartheid, que ainda vigora, e começou a ter um maior apoio da população negra em detrimento da branca. Em termos de política racial, a Namíbia assim começou a distanciar-se da África do Sul e a aproximar-se do Zimbábue.

Apesar de estes dois motivos tratarem especialmente da população e, portanto, da agência política, eles representam variáveis importantes sobre como os agentes leem a estrutura do Estado. O fato de a mudança do foco das políticas instituídas pelos governos estarem gerando reações oposicionistas que não questionam a existência das instituições estatais ou que levem atores políticos a quererem conquistá-las por meios outros que não pelas regras do jogo demonstra justamente a força de tal estrutura. Este é um ponto interessante: os regimes de segregação racial deram tal caráter à estrutura estatal que não deram outra opção que não as armas aos agentes políticos desses países uma vez que as regras vigentes não os incluíam no jogo político. Não é à toa que as guerras civis na Namíbia sob jugo sul-africano, na Rodésia e na África do Sul do apartheid cessaram justamente com a independência dos dois primeiros e com as eleições gerais de 1994 no terceiro: nos três casos, tais eventos culminaram no fim dos regimes de segregação racial. ${ }^{134}$

\footnotetext{
branca, que compunha apenas $6 \%$ da população nacional; boa parte da população negra ainda vivia em townships, tal como na África do Sul; e a própria constituição garantia a permanência da questão fundiária no pós-independência do país devido à pressão do Grupo de Contato (composto por EUA, R.U., Canadá, Alemanha e França) que mediava as negociações entre a SWAPO e o governo colonial de Windhoek. Apesar de esta situação ser bastante semelhante à África do Sul pós-1994, ela é completamente diferente do Zimbábue pós-independência (Ankomah, 2011).

${ }^{134}$ A situação demorou a se acalmar na África do Sul mesmo após as eleições gerais de 1994 que conduziram o CNA de Nelson Mandela ao poder. As desavenças que o partido teve com outros grupos políticos ao longo dos anos 1980 e início dos anos 1990 mantiveram-se ainda por algum tempo. Seus apoiadores confrontaram-se com partidários do Partido da Liberdade Inkatha (PLI) entre 1989 e 1996 e do Movimento Democrático Unido (MDU) entre 1997 e 1998, deixando 198 e 29 mortos respectivamente.
} 
De resto, a parcela da população nos outros países que afirmava concordar em obedecer ao governo e suas determinações mesmo que não tivesse votado nele foi igualmente alta e de diferença insignificante para as respostas dos PMDs que não passaram por guerras civil ou conflitos não-estatais. Assim, à exceção da Namíbia, é pouco provável que estas respostas sejam o retrato de um breve período de tempo ou tenham mudado e venham a mudar abruptamente.

A afirmação que se fez aos PMDs do capítulo anterior - de que tais resultados se deviam à cultura política das populações e ao fato de que estas estavam acostumadas a viver dentro de instituições políticas complexas tal como o Estado - vale também para este grupo de países, mas com algumas limitações. Os territórios de metade dos países analisados neste capítulo não tinham Estados tradicionais ou instituições políticas complexas no período pré-colonial. Este é o caso dos três Estados insulares (Cabo Verde, Maurício e Seicheles) e a Namíbia. Nos três primeiros, não havia assentamentos humanos anteriores à chegada dos colonizadores e, portanto, as populações que para lá migraram acostumaram-se logo cedo com as instituições políticas criadas pelo poder colonial. No caso da Namíbia, o choque institucional foi mínimo uma vez que o território que viria a ser a colônia do Sudoeste Africano. Lá, as populações indígenas eram nômades e pouco numerosas e não possuíam instituições políticas mais complexas quando o domínio alemão começou em 1884. Além disso, em 1928, os cerca de dois mil africâneres que haviam se assentado em Angola após as Dorslandtrekke (Caminhadas da Terra Sedenta) foram repatriados para o Sudoeste Africano. Esta população que não havia se habituado às instituições e aceito as determinações portuguesas assentou-se com maior facilidade nas instituições agora sob o jugo sul-africano (Stassen, 2010; Snyman, 2013). ${ }^{135}$

Os quatro países restantes analisados neste capítulo, Botsuana, Gabão, Suazilândia e Zimbábue, foram todos loci de Estados tradicionais que foram suprimidos ou divididos

\footnotetext{
Além disso, CATA e CODETA (duas cooperativas de taxi) enfrentaram-se 1994 e 1996, vitimando cerca de 71 pessoas, e União Nacional dos Mineradores (UNM) e União dos Trabalhadores Unidos da África do Sul (UTUAS) travaram combates que tiraram a vida de trinta pessoas entre 1989 e 1996.

135 As Dorslandtrekke tiveram início em 1874, durante o governo de Thomas François Burgers na República do Transvaal. Na ocasião, a nova legislação trabalhista combinada com incerteza política e dissidência interna geraram a emigração de parte dos bôeres. Com o passar do tempo, a Grã-Bretanha começou o processo de anexar a República do Transvaaal e o Estado Livre de Oranje (Oranje Vrystaat), antes mesmo da I Guerra dos Bôeres (1880-81), o que intensificou a emigração dessa população seminômade. Apesar de a convivência entre os colonos portugueses e os bôeres ter sido harmônica em Angola, a administração portuguesa naquela colônia não foi simpática ao uso do idioma africâner e muito menos à instituição de escolas naquele idioma. Por isto, os bôeres angolanos que já estavam dispostos a deixar Angola foram repatriados para o Sudoeste Africano - governado pela África do Sul - em 1928.
} 
pelos Estados coloniais, o que - tal como nos países do capítulo anterior - não foi capaz de apagar da memória coletiva das sociedades a vida em uma instituição política complexa tal como o Estado, principalmente porque seus territórios correspondiam em boa medida com a extensão dos Estados tradicionais ou porque eram continuação dos mesmos. O Reino de Orungu e o Império Rozvi declinaram diante da crescente influência europeia. No caso do primeiro, outras entidades políticas foram também postas junto com ele dentro do território que corresponde hoje ao Gabão enquanto o segundo chegou a controlar toda a extensão de terra correspondente ao Zimbábue atual, compreendendo os povos falantes de sindebele e xona. ${ }^{136}$

Tanto a Suazilândia quanto Botsuana passaram por uma experiência diferente dos congêneres do parágrafo anterior. Ambos foram protetorados ingleses e lograram manter e modernizar suas instituições indígenas durante tal período. O Reino da Suzilândia, por exemplo, teve seu auge entre 1840 e 1868, quando o Nkhosi Mswati II reinou e ampliou os territórios sob seu domínio e unificou-os em uma única entidade política. Especificamente, a unificação deu-se após os primeiros contatos com os trekboers do Transvaal, que sucessivas vezes planejaram expandir seus domínios sobre o território suazi. Em 1881, a Grã-Bretanha reconheceu a independência da Suazilândia, apesar do contexto de scramble e partilha do continente. A independência formal do reino durou pouco: apenas treze anos depois o Transvaal transformou-lhe em protetorado e manteveo em tal status até a eclosão da II Guerra dos Bôeres (1899-1902). A partir daí, a GrãBretanha retirou o reconhecimento da independência suazi e manteve a Suazilândia como protetorado seu até 1968, quando após eleições com base na nova constituição do país promulgada em Londres cinco anos antes determinaram a nova independência do país.

Botsuana, por sua vez, conseguiu manter suas instituições políticas tradicionais mais íntegras e imunes a influências estrangeiras em seu processo de modernização. Em 1885, os reinos Tsuana tornaram-se protetorados da Grã-Bretanha mas continuaram gozando de bastante autonomia administrativa devido ao governo indireto, característica principal da colonização inglesa no continente. Na verdade, a criação do protetorado na época fora um pedido do governo local que temia as investidas do Trasnvaal. Exatos dez anos após a criação do protetorado de Bechuanalândia, os três Dikgosi Khama III, Sebele I e Bathoen I viajaram até Londres para pedir ao secretário de Estado para as colônias, Joseph

\footnotetext{
${ }^{136}$ Este último também é encontrado em Moçambique, Zâmbia e Zimbábue.
} 
Chamberlain, e à Rainha Vitória que o protetorado não fosse incorporado à Rodésia do Sul e ficasse fora da jurisdição da Companhia Britânica da África do Sul (CBAS) de Cecil Rhodes. Com o pedido atendido, Bechuanalândia também logrou resistir às tentativas da Inglaterra em anexá-la à África do Sul e pôde manter seu sistema político tradicional durante todo o período colonial e estabelecê-lo como base do novo país quando da sua independência, agora sob o nome de Botsuana. Entre vários exemplos de continuidade das instituições, a democracia de Bostuana, por exemplo, construiu-se com base no sistema de kgotla (conselho de vila), um sistema tradicional de democracia direta (Holm, 1993; Gentili, 2012). ${ }^{137}$

Assim, a questão levantada no capítulo anterior sobre se estes Estados compartilhavam do mesmo modo de projeção de poder e da autoridade sobre o território que seus congêneres pré-coloniais permanece válida e necessária. Neste sentido, a existência de relações de vassalagem dentro dos limites territoriais dos Estados précoloniais e os diferentes graus de complexidade institucional que detinham poderiam ter culminado em diferentes relações de poder e percepções dos novos Estados. No entanto, a medição feita por Morrison, Mitchell e Paden (1989) sobre o grau de semelhança das instituições tradicionais com o Estado pós-colonial é de pouca valia para o grupo de países analisado neste capítulo: dos oito deles, apenas três tiveram valores atribuídos pelos autores supracitados. Isto se deve ao fato de que Cabo Verde, Maurício e Seicheles eram desabitados quando da chegada dos europeus e, portanto e obviamente, não possuíam instituições pré-coloniais, e também à dificuldade em classificar a Namíbia e o Zimbábue.

Como já dito, o território hoje correspondente à Namíbia não possuía instituições précoloniais. A população que lá vivia era nômade e pouco numerosa e não desenvolveu instituições políticas mais complexas, isto é, era tribal. Essas populações, no geral, estabeleceram pouco contato entre si por causa da imensa dificuldade de migração e trânsito imposta pelos imponentes desertos do Kalahari e do Namibe, que cobrem cerca de $80 \%$ do território do país. Dos vários povos que lá se assentaram, os Oorlams, os Baster

\footnotetext{
${ }^{137}$ Referência de Holm (1993) em Englebert (2000b). As kgotlas são reuniões públicas de um conselho comunitário responsáveis por debater e tomar decisões referentes aos assuntos da comunidade. Geralmente, suas decisões são tomadas por consenso.
} 
e os Ovambos merecem destaque, pois podem ter desenvolvido alguma complexidade institucional que lhes aproximassem de um Estado. ${ }^{138}$

Os Oorlam eram uma subtribo dos Nam, migrantes assimilados da Colônia do Cabo (território que hoje corresponde às províncias sul-africanas do Cabo Setentrional, Cabo Ocidental e Cabo Oriental) que deixaram a região para escapar do jugo colonial holandês e mudaram-se para as atuais Namaqualândia e Damaralândia, na Namíbia. Tratava-se de uma raça mista, descendentes de Khoikhoi que haviam crescido e servido nas fazendas dos Bôeres na colônia, de europeus e de outros grupos étnicos. Eles adotaram muitos dos costumes e forma de vida do Cabo Holandês, como a língua (o africâner), o uso de cavalos e armas de fogo, a forma de vestir e o Cristianismo. Conheceram seu auge entre 1823 e 1861 quando o Kaptein Jonker Afrikaner habilmente conseguiu transformar-lhes em um Estado de facto, após dominar os Namas (de quem cobrou tributos) e combater os Hereros. Por volta de 1840, o kaptein chegou a governar cerca de 5500 pessoas (OmerCooper, 1987). ${ }^{139}$

Os Baster - o outro povo que merece destaque - eram descendentes de homens bôeres e mulheres Nama. Seu nome deriva do holandês bastaard (filho ilegítimo ou mestiço). Falavam africâner, tal como os Oorlam, e consideravam-se culturalmente mais brancos do que negros. Deixaram a Colônia do Cabo em 1869 e instalaram-se em uma área entre os desertos do Namibe e do Kalahari, onde fundaram a cidade de Rehoboth. Com o crescimento da população (por nascimento e migração), a Rehoboth Gebiet (a cidade mais a área aos seus arredores) demandava maior institucionalização da administração da coisa pública e, como consequência, foi fundada a República Livre do Rehoboth, cujo kaptein (chefe do poder executivo) e os três membros do Volksraad (Conselho do Povo, em português, ou seja, um parlamento) eram escolhidos em eleições diretas. A república era regida por uma constituição conhecida como Vaderlike Wette (Leis Paternas), vigente até os dias atuais na cidade. Em 1885, quando a colonização alemã começou sobre o Sudoeste Africano, Rehoboth assinou o Tratado de Proteção e Amizade com o Império Alemão, no

\footnotetext{
${ }^{138}$ Outros povos que habitaram na época pré-colonial o território atualmente correspondente à Namíbia são os San (Bushmen), os Kavangos, os Damara e os Hereros. Cada um desses grupos era dividido em subgrupos com diferentes denominações.

${ }^{139}$ A transmissão do título de kaptein (capitão, em africâner) era hereditária mesmo antes da consolidação do Estado de facto por Jonker Afrikaner. Ele herdou-o de seu pai Jager Afrikaner quando este morreu em 1821. Em 1861, quando faleceu, seu filho Christian Afrikaner herdou o título o qual transmitiu ao irmão Jan Jonker Afrikaner dois anos mais tarde.
} 
qual garantia certo grau de autonomia mas reconhecia o jugo do governo colonial (Orizio, 2000).

Por fim, os Ovambos - que hoje constituem o maior grupo étnico da Namíbia migraram para o território que hoje corresponde ao país em meados dos séculos XV e XVI. Uma vez já instalados no norte do Sudoeste Africano, organizaram-se em sete comunidades relacionadas que - com a exceção de uma (a Uukolankadhi) - passaram por processos de centralização do poder e de fundação de reinos, como consequência do desenvolvimento de economias agro-pastorais e a consequente necessidade de controle sobre a terra. No geral, o rei (Omukuwaniilwa) em cada comunidade era escolhido pelo clã e recebia assistência de um grupo de conselheiros (Omutumba gomalenga omakuluntu), que eram designados pelo próprio e exercia funções executivas, legislativas e judiciárias e eram presididos por um ministro-chefe (Elenga Ekuluntu). Nestes sistemas bastante centralizados, o rei tinha poderes amplos que lhe conferiam, entre outras coisas, o controle total sobre o exército e o clero e também sobre tudo e todos em seu reino (Williams F. N., 1994). ${ }^{140}$

Por sua vez, o território hoje correspondente ao Zimbábue foi terra de vários Estados tradicionais que variaram em extensão, longevidade e administração política. Lá encontrava-se o famoso Império do Monomotapa e também os Estados Ndebele, referidos no capítulo 2. Na verdade, aquela região foi palco de Estados tradicionais desde pelo menos o século XI, quando o Reino do Mapungubwe surgiu. Sucederam-no vários Estados Xona entre os séculos XIII e XV, dentre os quais destaca-se o Reino do Zimbábue (também referido como Império do Monomotapa) que, inclusive, chegaram a guerrear contra a presença da Coroa Portuguesa na região no século XVII. No século seguinte, outros Estados Xona organizaram-se na tentativa de oferecer uma resposta à crescente presença europeia na região e ao declínio do Monomotapa e uniram-se baixo o Reino de Rozvi. Também os Ndebele se organizaram em um reino que, de tão poderoso, invadiu e incorporou o Reino de Rozvi e assumiu o nome Mthwakazi (referido pelos europeus como Matebele), que em língua zulu significa “aquele que é grande na concepção". Este novo Estado era etnicamente bastante diverso, tinha um sistema político centralizado e era

\footnotetext{
${ }^{140}$ Citada em Keulder (2000). Keulder também classificou os modos de liderança pré-coloniais e coloniais em três classes: os reinos, cujos Ovambos são os exemplos; o caciquismo (chieftainship), exemplificados pelos povos que migraram da Colônia do Cabo para o território do Sudoeste Africano, tal como os Oorlams e os Basters, e também pelos Hereros; e os headmanships, estruturas criadas no período colonial para garantir o controle sobre as comunidades reassentadas ou organizar e controlar comunidades acéfalas.
} 
baseado em um sistema militar bastante forte. Bulawayo, sua capital, é ainda hoje a segunda maior e mais rica cidade do Zimbábue (Isichei, 1997).

Atribuir valores que possam mensurar o grau de semelhança das instituições tradicionais com o Estado pós-colonial da Namíbia e do Zimbábue é um exercício arriscado, mas que pode - mais do que dar robustez - permitir a análise e comparação do grupo de países analisados neste capítulo com os do capítulo anterior e com o resto do continente. Os riscos residem no fato de que 1) seria muito difícil proceder com a mesma análise e avaliação que os autores fizeram e que as informações apresentadas indicam um caminho, mas - mesmo atendendo a critérios utilizados - não se pode ter certeza dos valores que receberia e que 2) os valores apresentados pelos autores são valores médios das classificações que fizeram das diferentes entidades políticas que identificaram ao longo do período analisado.

Tabela 9 - Grau de Semelhança com Estado de Morrison, Mitchell e Paden (1989) ${ }^{141}$ e 142

\begin{tabular}{llll}
\hline SEM GUERRA CIVIL & $\begin{array}{l}\text { Grau de } \\
\text { semelhança com } \\
\text { Estado }\end{array}$ & $\begin{array}{l}\text { SEM CONFLITOS } \\
\text { MENORES }\end{array}$ & $\begin{array}{l}\text { Grau de } \\
\text { semelhança com } \\
\text { Estado }\end{array}$ \\
\hline Gabão & 1,00 & $\begin{array}{l}\text { Botsuana } \\
\text { Cabo Verde } \\
\text { Maurício }\end{array}$ & 2,00 \\
& $\begin{array}{l}\text { Namíbia } \\
\text { Seicheles } \\
\text { Suazilândia } \\
\text { Zimbábue }\end{array}$ & 0 ou 1,00* \\
& 3,00 \\
& & 2,00 ou $3,00 *$ \\
\hline
\end{tabular}

Fonte: Englebert (2000b), elaboração própria.

Para lidar com o primeiro risco, é necessário ter em mente que por um lado, a Namíbia pré-colonial encontra-se em algum estágio entre uma localidade cuja população era numericamente insignificante (devido em boa parte ao genocídio alemão contra os Hereros e os Namaquas) e uma região com três experiências de sofisticação institucional. No primeiro caso, faz sentido à Namíbia não ser atribuído nenhum valor e o país não entrar na análise. No segundo, não seria errado atribuir-lhe o valor mínimo 1 e classificá-

\footnotetext{
141 Vide nota 79, página 124.

${ }^{142}$ Os casos marcados com um * estavam em branco no trabalho original. Os valores atribuídos a eles nesta tabela são de responsabilidade do autor desta pesquisa.
} 
la como uma sociedade acéfala e segmentária. Por outro lado, a história pré-colonial do território correspondente ao Zimbábue hoje é rica em instituições políticas mais complexas que se basearam tanto em sistemas de vassalagem como em sistemas de poder centralizado. Deste modo, não seria equivocado afirmar que houve durante os últimos mil anos chefaturas sem importância e chefaturas tribais maiores e reinos, que lhe garantiriam 2 como valor mínimo e 3 como valor máximo. ${ }^{143}$

Ao classificar tais locais com a atribuição do valor absoluto (1,2 ou 3) como se fosse a média do período pré-colonial, obteve-se uma banda de valores médios mínimos e máximos para todos os subgrupos nos quais estes dois países foram inseridos, lidando assim com o segundo risco. Como visto na breve descrição da história pré-colonial desses dois países, o cenário mais provável é que o território correspondente à Namíbia fosse um vazio político e humano, portanto, sem instituições políticas maiores e mais complexas e a região onde hoje é o Zimbábue tivesse sido local de chefaturas pequenas e sem importância na maior parte do tempo. ${ }^{144}$ Essa banda é confiável uma vez que o valor médio do cenário mais provável (como visto na breve descrição da história pré-colonial dos países da Namíbia e do Zimbábue) está dentro dela e é quase que equidistante a ambas extremidades. ${ }^{145}$

Neste quesito, impressiona a semelhança dos não-PMDs que nunca passaram por guerras civis ou conflitos não-estatais com os PMDs que também nunca tiveram tal

\footnotetext{
${ }^{143}$ Trata-se aqui, portanto, de cometer o Erro do Tipo 1 (rejeitar a hipótese nula quando ela é verdadeira) ou o Erro do Tipo 2 (não rejeitá-la, apesar de ser falsa). Para fazê-lo, a hipótese nula foi considerada como a que somaria o menor valor ao período pré-colonial de cada país: ausência de sistemas políticos e vazio humano na Namíbia pré-colonial (valor 0) e presença de chefaturas pequenas e sem importância no Zimbábue pré-colonial (valor 2). A hipótese alternativa, por exclusão, é a que atribuiria maior valor aos casos: classificar a Namíbia pré-colonial como sociedade acéfala (valor 1) e classificar o Zimbábue précolonial como chefaturas tribais e reinos (valor 3).

${ }^{144} \mathrm{O}$ cenário mais provável é o Erro do Tipo II. Esta é, na verdade, uma avaliação conservadora sobre o Zimbábue pré-colonial. A quantidade de pequenos Estados que compunham as civilizações Xona, por exemplo, corroboram tal escolha apesar de contrastarem com a complexidade do Império do Monomotapa. Talvez seja mais correto dizer que o Zimbábue pré-colonial esteja entre os valores 2 e 3, mais próximo do primeiro. Como não foi possível calculá-lo com exatidão, atribuiu-se o valor médio 2. No caso da Namíbia, a existência dos reinos Ovambo e dos caciquismos dos Oorlams e dos Basters argumentariam em favor de classificá-la de acordo com a hipótese nula. A questão, no entanto, é se eles chegaram ou não a representar população grande o bastante para tornar a memória coletiva significativa. Quanto aos dois últimos, a resposta seguramente é não.

${ }^{145}$ Não há significância nas diferenças entre os valores médicos para qualquer combinação de Erros de Tipo I e II com os dois países em questão. O valor médio mínimo foi de 1,8 e seu desvio padrão de 0,84 (Erro de Tipo I para Namíbia e Erro de Tipo II para o Zimbábue) e o valor médio máximo foi de 2,25 com desvio padrão de 0,96 (Erro de Tipo II para Namíbia e Erro de Tipo I para o Zimbábue). O cenário mais provável (Erro de Tipo II para ambos os países) traz a média 2 com desvio padrão 0,82 . O cenário menos provável (Erro de Tipo I para ambos os países) tem média 2 e desvio padrão 1.
} 
experiência desde a independência. Não há diferença significante entre o valor médio de semelhança entre os Estados pré e pós-colonial entre esses dois grupos tanto no cenário mais provável como nos dois extremos da banda mencionada acima. Assim sendo, tudo parece indicar que também nos países analisados neste capítulo o fator responsável pela ausência de tais tipos de conflito armado não é o maior nível de desenvolvimento, mas sim a estrutura estatal melhor estabelecida. Até o momento, todos os fatores que influenciam na agência (com a óbvia exceção do desenvolvimento) são bastante similares aos que agiram sobre os PMDs que não sucumbiram ao colapso estatal e aos que agiram sobre os países que sim colapsaram. Isto indica que há algo capaz de inibir os impulsos dos agentes políticos a pegar em armas e promoverem o colapso do Estado: também nos oito países analisados neste capítulo - como se demonstra - é a autoridade estatal.

Como já visto, um dos componentes da autoridade estatal que interfere diretamente no nível da autoridade do Estado é a geografia. Não apenas o tamanho do território, mas também a forma como sua população está distribuída sobre ele interfere diretamente na capacidade de o Estado projetar poder e consolidar sua autoridade. Neste sentido, algumas das conclusões do capítulo anterior são também válidas para os oito países que nunca passaram por guerras civis analisados neste capítulo. Também estes indicam que, quando se trata de estabilidade e evitar a guerra, o menor tamanho é documento mesmo quando se trata de um subgrupo que exclua os países insulares. Ao olhar para os oito países, notase que quatro deles (sendo três insulares) estão no primeiro quartil dos Estados africanos organizados de acordo com sua área, uma proporção maior que a dos PMDs pacíficos (cinco de países; sendo um insular). No entanto, os subgrupos que excluem os países insulares apresentam uma diferença interessante: apenas um dos cinco não-PMDs pacíficos está no primeiro quartil contra 6 dos 12 PMDs pacíficos. A grande questão, no entanto, é que as diferenças das médias dos 2 grupos e dos 2 subgrupos não são significantes - o que fortalece neste capítulo a validade das conclusões do capítulo anterior.

Além da insignificância da diferença das médias, um primeiro fator que os assemelha é o fato de que também neles a projeção do poder e a consolidação da autoridade estatal tinham como alvo principal a população, e não território, e sendo assim, quanto menor o território, maior a acessibilidade à população e maior a chance de conseguir dividendos provenientes dos impostos cobrados. Os não-PMDs que nunca passaram por guerra civil e conflitos não-estatais beneficiaram-se (do mesmo modo que os PMDs pacíficos) da 
facilidade que o tamanho diminuto do território lhes apresentou: por mais que a lógica dos retornos decrescentes em escala na questão da projeção do poder seja válida, o tamanho reduzido de seus territórios permitiu-lhes consolidar sua autoridade ainda dentro do alcance estatal, diminuindo os efeitos dos retornos decrescentes em função das distâncias.

Os tamanhos, no entanto, não são os únicos responsáveis por garantir que esta componente constante da estrutura estatal facilite a projeção do poder e a consolidação da autoridade estatal. Em todo o continente, como dito no capítulo anterior, as formas das colônias foram alteradas de modo a garantir determinada densidade demográfica e assim torná-las lucrativas para as metrópoles ou companhias metropolitanas que as administravam. Foi exatamente por este motivo que a CBAS pretendia anexar o protetorado da Bechuanalândia à Rodésia do Sul, episódio que rendeu fama histórica aos três dikgosi do país. No entanto, quando a Grã-Bretanha aceitou criar o protetorado sobre aquele Estado tradicional, criou também uma colônia que pertenceria à Coroa (Bechuanalândia Britânica). Este território ao sul do protetorado teve vida curta em tal status e fora anexado à Colônia do Cabo no mesmo ano em que os três dikgosi apresentaram à Coroa a indisposição de serem anexados à Rodésia e serem administrados pela CBAS.

Anos depois, os ingleses lograriam criar a Federação da Rodésia e da Niassalândia (ou Federação da África Central), que durou entre 1953 e 1963 e unificou os protetorados da Niassalândia, Rodésia do Norte e Rodésia do Sul (Zimbábue). Estes dois casos retrataram a intenção da Grã-Bretanha em otimizar a natureza da geografia política destes protetorados: tentou unificar os territórios correspondentes a Botsuana e Zimbábue (de geografia política favorável à projeção do poder) e deste último com a Zâmbia e o Maláui (de geografia política neutra). O mesmo aconteceu com a colônia francesa do Gabão (de geografia política favorável), de colonização francesa, que em 1910 foi anexado à África Francesa Equatorial. Além deste, tal unidade colonial era composta pelos territórios hoje correspondentes à República do Congo e à República Centro Africana (ambos de geografia política favorável), à maior parte de Camarões (de geografia política neutra) e ao Chade (hinterlândia). ${ }^{146}$

\footnotetext{
${ }^{146}$ Concluída a I Guerra Mundial, a colônia alemã dos Camarões foi dividida entre França e Inglaterra. A primeira ficou com a maior parte, inclusive com uma das duas zonas de maior densidade demográfica (no norte do território, mais próxima do Chade).
} 
Tal como nos países do capítulo anterior, as mudanças feitas nas fronteiras das colônias não resultaram nos benefícios que eram esperados (melhorias na governabilidade e no incremento da rentabilidade sobre a taxação). Desta forma, tanto a Federação da África Central (inglesa) como a África Equatorial Francesa foram desfeitas e as divisas anteriores foram reestabelecidas de modo a garantir pelo menos a restauração da autoridade da administração colonial e o rendimento da taxação anterior. Assim, também em Botsuana, Gabão e Zimbábue as fronteiras coloniais tornaram-se as fronteiras dos novos Estados e garantiram-lhes uma posição de vantagem em relação a alguns dos países que compuseram as experiências amalgamentes das quais fizeram parte. Como resultado, pode-se afirmar que as alterações não reproduziram as melhorias na projeção de poder e o incremento na rentabilidade da taxação que eram esperados uma vez que teriam diluído os benefícios daquelas com geografias políticas favoráveis em unidades não favoráveis. Em outras palavras, tais experiências não melhoraram o poder da autoridade colonial.

Assim como os PMDs que nunca passaram por guerra civil ou conflitos não-estatais, os países deste capítulo também têm, em sua maioria, geografia política favorável à projeção do poder e à consolidação da autoridade estatal. Tal característica foi perpetuada no período pós-colonial uma vez que o processo de descolonização não resultou em alterações aos territórios das colônias e às consequentes oportunidades e constrangimentos da difusão do poder. Excluindo-se os países insulares (Cabo Verde, Maurício e Seicheles), quatro dos cinco países analisados neste capítulo têm geografia política favorável e apenas um, difícil. Isto reforça o argumento sugerido no capítulo anterior de que os colonizadores fizeram o cálculo sobre o tamanho do território e da população e como esta estava distribuída sobre o aquele antes de repartir o terreno. Neste sentido, a permanência de algumas entidades políticas tradicionais e suas definições territoriais corroboram não apenas com tal sugestão, mas também com o fato de que a geografia desempenhou papel crucial na projeção do poder e na consolidação da autoridade estatal nos Estados africanos.

No caso de Botsuana, a habilidade dos líderes dos três dikgosi fez com que o território do protetorado de Bechuanalândia praticamente correspondesse aos alcances dos reinos Tsuana. A própria divisão do protetorado em duas partes (Protetorado de Bechuanalândia e Bechuanalândia Britânica) acabou somente favorecendo a geografia política do protetorado e do país que nasceria em 1966. Também este foi o caminho pelo qual a Suazilândia passou. Com o fim da Guerra dos Bôeres, o reino tornou-se oficialmente um 
protetorado da Grã-Bretanha, que passou a encarregar-se de vários setores de sua administração pública. O governo indígena e o território original, contudo, foram vastamente mantidos. Além destes, o Zimbábue também teve uma importante coincidência e sobreposição da Rodésia sobre os Estados tradicionais que lá estavam, herança dos tempos em que a CBAS de Cecil Rhodes o controlava.

Por outro lado, a Namíbia é um país de geografia difícil no qual, historicamente, uma grande parte da população concentra-se na região da capital Windhoek e pouco menos da metade na província setentrional de Ovambolândia. Curiosamente, a construção do país e as medidas que os governos centrais tomaram para compensar as dificuldades apresentadas pela geografia tiveram tendências contrastantes: o governo colonial buscou descentralizar a autoridade com a finalidade de dar capilaridade no alcance da administração estatal enquanto o governo da SWAPO tratou de aumentar a institucionalização da autoridade estatal, estabelecendo um novo relacionamento entre o Estado e os líderes tribais. Apesar de o governo do primeiro-ministro Jan Smuts (19191924) ter estabelecido um controle tão forte sobre a economia da Namíbia, o que praticamente realizou sua intenção de transformá-la em uma província sul-africana, a marca principal da administração da União Sul-Africana sobre a antiga colônia alemã foi a descentralização do governo e o chamado governo indireto. ${ }^{147}$

Neste caso, a ideia era garantir a distância espacial entre os vários grupos da população de modo a garantir a hegemonia da população branca. Assim, áreas da Ovambolândia tiveram líderes tribais que exerciam autoridade em determinados distritos sendo que, em alguns casos, eles tinham o apoio dos omutumba gomalenga omakuluntu (conselhos de anciões tribais) e gozavam de jurisdição civil e criminal sobre seus povos. 148 Após a independência, a reorganização pela qual passou o estado namibiano aboliu tal sistema criado pela União da África do Sul e transferiu o poder dos líderes tradicionais para os Conselhos Regionais, que os submeteu. O Ato das Autoridades Tradicionais teve assim dois impactos maiores sobre os líderes indígenas. Ele reduziu significativamente sua capacidade de implementar políticas públicas e de aplicação da lei e aboliu as chamadas "polícias tribais". Além disso, o ato também garantiu que o único papel oficial

\footnotetext{
147 Vide nota 100, página 139.

${ }^{148}$ Exceto sobre os crimes de assassinato, estupro, traição e lesão corporal grave. Nestes casos, o ofensor era levado à Divisão do Sudoeste Africano da Suprema Corte da África do Sul.
} 
desempenhado pelas autoridades tradicionais no que se refere às áreas rurais é o de apoiar as estruturas estatais (du Pisani, 2000; Tötemeyer, 2000; Keulder, 2000; Tordoff, 2002).

Estas políticas adotadas na Namíbia tanto no período colonial quanto independente estão diretamente relacionados com a legitimidade vertical dos Estados. Apesar de esta não ter parecido ser muito importante como fator garantidor da paz e da autoridade estatal entre os trezes PMDs (já que apenas dois deles a tinham), esta proporção é bastante superior nos não-PMDs que nunca passaram por guerras civis ou conflitos não-estatais (cinco sobre oito). Esta importante diferença é significante no tocante aos níveis de desenvolvimento dos Estados, tal como argumentou Englebert (2000b). Contudo, a legitimidade vertical parece sim ter tido alguma contribuição para a estabilidade e paz nos países africanos, sobretudo nos insulares: dos seis países africanos insulares, quatro têm legitimidade vertical e nunca passaram por guerra civil ou conflitos não-estatais.

Além de São Tomé e Príncipe (que foi tratado no capítulo anterior), também Cabo Verde, Maurício e Seicheles têm legitimidade vertical. ${ }^{149}$ Estes quatro países conseguiram tal status uma vez que eram completamente desabitados quando da chegada dos colonizadores. Desta forma, as instituições que foram construídas nesses países acompanharam a evolução de uma população que não conhecia outra forma de instituições políticas. De todo modo, é preciso considerar que a concentração da população em algumas das ilhas desses países poderia ter representado um constrangimento na difusão do poder. No entanto, o fato de o território ser diminuto e limitado pelo mar tem um papel dúbio. Tal como em São Tomé e Príncipe, Maurício e Seicheles têm mais de $90 \%$ da população concentrada em uma única ilha de seus arquipélagos e Cabo Verde tem quase $56 \%$ da população em uma única de suas nove ilhas habitadas. ${ }^{150}$ Desta condição, a concentração populacional neles pode tanto garantir a melhor governabilidade e o maior alcance do Estado sobre a vasta maioria da população como também pode gerar na parcela minoritária descontentamentos cuja força pode superar e desafiar a estrutura estatal. Dado os altos níveis de autoridade estatal desses dois

\footnotetext{
${ }^{149}$ Comores e Madagascar são os outros países insulares da África. Eles não têm legitimidade vertical e já foram palco de guerras civis ou conflitos não-estatais. Dos dez países com legitimidade vertical, apenas Burundi, Etiópia e Ruanda passaram por guerras civis ou conflitos não-estatais. Botsuana e Suazilândia (não-PMDs) e Lesoto (PMDs) são os países com legitimidade vertical restante que não passaram por guerra civil ou conflitos não-estatais. Os três lograram manter ou recuperar as instituições políticas indígenas após as independências.

150 Statistics Mauritius (2013), Central Intelligence Agency (2016).
} 
Estados, é possível argumentar que caso fossem países continentais, teriam geografia política favorável à projeção do poder e à consolidação da autoridade estatal. ${ }^{151}$

Ora, os fatores constantes que compõem a estrutura dos Estados e fortalecem a autoridade estatal parecem ter contribuído enormemente em todas as componentes desta última, tal como demonstram os dados sobre ausência de violência política e terrorismo, efetividade da governança e nomocracia apresentado no começo deste capítulo. Tal como entre os PMDs, a geografia política e a legitimidade vertical deram importantes contribuições para a autoridade estatal nos oito países analisados neste capítulo e, consequentemente, criaram um ambiente no qual os agentes políticos não viram interesse ou probabilidade de atingir seus objetivos por via das armas. O problema é que apenas estas duas componentes não são capazes de explicar a manutenção e o fortalecimento da autoridade estatal do período pré-colonial ao pós-colonial uma vez que instituições alienígenas foram implantadas em alguns países deste grupo e tiveram que concorrer com outras fontes de autoridade ao passo que em outros países a modernização das instituições alienígenas teve de ser feita buscando sempre o equilíbrio entre os atores políticos (tradicionais ou não).

\subsection{Costume, resiliência e capilaridade da autoridade estatal}

Combinar a estrutura estatal e sua autoridade com a autoridade dos líderes tradicionais não é, portanto, algo que se deva analisar apenas nos países sem legitimidade vertical. Por um lado, Namíbia, Gabão e Zimbábue não tem legitimidade vertical e precisaram, de algum modo, conseguir de fazer coexistir a autoridade estatal e a dos líderes tradicionais. Por outro, Botsuana e Suazilândia têm legitimidade vertical e cunharam alterações em suas instituições que os obrigaram a lidar com a questão dos líderes tradicionais. A ideia subjacente de que a capacidade administrativa e a autoridade estatal se somam aos governos tradicionais também está presente nos oito não-PMDs que nunca passaram por guerra civil ou conflito estatal. Como já dito, esta regra de atrair os líderes tradicionais os processos mais comuns de construção estatal foi uma tendência na África Subsaariana ao logo dos anos 1990 e 2000.

\footnotetext{
${ }^{151}$ A analogia feita no capítulo anterior com Senegal e o movimento separatista de Casamança também foi aplicada aqui como indicador de um país com geografia política difícil. No entanto, o que Seicheles e Maurício demonstram é que a concentração de sua população representa na verdade o fato de que "os anéis concêntricos da densidade populacional correspondem ao entendimento atual da soberania" (Herbst, 2000, p. 154).
} 
O que foi feito na Namíbia e no Zimbábue, por exemplo, serve para mostrar que esta onda atingiu até mesmo países com maiores índices de desenvolvimento. No entanto, o grau de confiança que as populações desses oito não-PMDs têm nos líderes tradicionais é grande (54\%), porém significativamente menor do que nos PMDs. ${ }^{152}$ Nos países analisados neste capítulo, a proporção de pessoas que confia nos líderes tradicionais é maior na zona rural do que na zona urbana. $\mathrm{O}$ único país que difere um pouco desta regra é Botsuana cuja população rural confia mais nos líderes tradicionais, mas que a diferença entre ela e a zona urbana não é significativa: uma clara consequência da construção do Estado desde o período pré-colonial, que foi encabeçada pelos líderes dos reinos batsuana. Além disso, estes oito países apresentam tendência crescente dos níveis de confiança popular nos líderes tradicionais. Esse crescimento chama a atenção especificamente na Namíbia onde a incorporação das lideranças tradicionais ao aparato estatal surtiu efeito: ao passo que a população passou a confiar mais nos líderes tradicionais, também passou a acreditar na importância de obedecer ao governo e às suas determinações, independentemente de para quem se votou.

Tal como nos PMDs pacíficos, as instituições tradicionais mostraram-se um jeito de contornar dificuldades impostas pela geografia política e pela falta de legitimidade vertical e assim favorecer a projeção do poder e a consolidação da autoridade estatal sobre a distância. Também nos não-PMDs, essas lideranças têm potencial principalmente para exigir o cumprimento das leis e formular políticas públicas para determinada população e também garantir alguma forma de nomocracia, visto que as regras comunitárias em muitos casos se aplicavam também aos líderes tradicionais. Este é o caso, por exemplo, dos Elenga Ekuluntu, na Ovambolândia (norte da Namíbia). Hodiernamente, tais chefes tribais são eleitos pelos seus clãs e são responsáveis por assuntos locais, tal como a resolução de litígios e disputas e o gerenciamento das terras comunitárias.

Nos outros países analisados neste capítulo também, a luta pela consolidação da autoridade estatal passou assim não só pela disputa sobre quem seriam os tomadores de

\footnotetext{
152 Pesquisa feita pelo Afrobarometer (2015) perguntou aos entrevistados "quanto você confia em cada um dos seguintes, ou não ouviu falar suficientemente sobre eles para dizer? Líderes tradicionais". Os respondentes podiam escolher entre "nada", "bem pouco", "um pouco" ou "bastante". Os números apresentados aqui são a soma das respostas "um pouco" e "bastante". A pesquisa entrevistou 8398 pessoas em Botsuana, Gabão, Namíbia, Suazilândia e Zimbábue e também foi feita em outros 18 países do continente, totalizando 46743 entrevistados. Duas pesquisas semelhantes foram realizadas em $2003 \mathrm{e} \mathrm{em}$ 2009. Seus resultados fortalecem a interpretação apresentada acima. Também foram realizadas tais pesquisas na Argélia, Egito, Marrocos e Tunísia, que não foram consideradas nesta análise uma vez que tais países estão fora da área geográfica que constitui o objeto de estudo desta pesquisa.
} 
decisão mais influentes sobre as populações, mas também sobre a posse da terra. Neste ponto, as políticas adotadas pelos Estados pós-coloniais variaram entre a propriedade individual, que favorecia as autoridades e práticas tradicionais, e a estatal, que as desafiava. Também entre os não-PMDs que nunca tiveram guerra civil ou conflitos nãoestatais, o maior desafio às práticas tradicionais de posse da terra foi feito não pela oposição ou supressão, mas pelo seu reconhecimento e legalização. Fazendo uso da sistematização de Herbst (2000) utilizada no capítulo anterior sobre os tipos de propriedade da terra na grande maioria dos Estados africanos, observa-se primeiro que os não-PMDs pacíficos tiveram no geral maior diversidade nos tipos de propriedade de terras permitidas do que os PMDs que nunca tiveram guerra civil ou conflitos não-estatais, isto é, admitiam tanto a propriedade privada quando estatal da terra quanto seu mandato costumeiro de modo mais significativo. Dado que aqueles têm melhores índices de eficácia da governança e de nomocracia do que estes, é possível argumentar que a cada vez maior participação das lideranças tradicionais nas estruturas estatais tem favorecido a autoridade estatal e, assim, permitido maior presença dos Estados nos rincões mais distantes.

Dentre os cinco países que se encaixaram nesta avaliação feita por Herbst, chama a atenção primeiro de que o Gabão, único país onde não há propriedade estatal da terra nem reconhecimento explícito do mandato costumeiro da terra, chegou a ter violência mais intensa do que seus congêneres analisados neste capítulo. Além disso, este país tem apenas a sexta melhor média em autoridade de 1996 a 2011 dos oito países analisados neste capítulo. Por mais que seu desempenho médio não tenha sido muito bom quando comparado com os outros países da mesma categoria, sua geografia política favorável à projeção do poder e à consolidação da autoridade estatal ajudou a manter o nível de autoridade do país alto: o país teve o $13^{\circ}$ melhor desempenho médio dos 48 países para os quais estão disponíveis os dados sobre autoridade estatal no período analisado. Durante o período, o país ainda tinha terras disponíveis, o que fazia diminuir os incentivos para o conflito. ${ }^{153}$

Com relação aos outros cinco países deste grupo que o autor analisou, todos têm uma boa diversificação nas modalidades de posse e aquisição da terra. Botsuana, Namíbia,

\footnotetext{
${ }^{153}$ Entre os países analisados neste capítulo, os melhores desempenhos médios em autoridade estatal são de Maurício $\left(1^{\circ}\right)$, Botsuana $\left(2^{\circ}\right)$, Cabo Verde $\left(3^{\circ}\right)$, Seicheles $\left(4^{\circ}\right)$, Namíbia $\left(5^{\circ}\right)$, Gabão $\left(13^{\circ}\right)$, Suazilândia $\left(22^{\circ}\right)$ e Zimbábue $\left(37^{\circ}\right)$.
} 
Suazilândia e Zimbábue todos reconhecem explicitamente o mandato costumeiro sobre a terra e permitem (em maior ou menor grau) tanto a posse privada quanto a posse estatal sobre a mesma. Destes quatro, apenas a Namíbia tem geografia política difícil. Ainda hoje, a questão da terra é um problema no país e fonte de tensão uma vez que as terras indígenas foram tomadas durante o período colonial e praticamente três quartos das terras aráveis foram transferidas para as mãos de colonos brancos, uma situação que o governo do país tenta timidamente mudar. Situação semelhante é a do Zimbábue, país com geografia política favorável. Também lá o colonialismo mudou radicalmente as regras para posse da terra e hoje um pequeno número de fazendeiros brancos controla a maior parte das terras aráveis do país. Neste caso, a tensão latente sobre a terra talvez só não tenha escalado e eclodido em conflitos devido à sua geografia favorável, o que facilita a presença do Estado (inclusive de seu aparato militar) nos focos de tensão. Na Suazilândia, a estrutura fundiária é bastante dual ainda como consequência da divisão entre áreas europeias e nativas durante o período em que foi um protetorado britânico. Na época, cerca de dois terços das terras foram destinadas às reservas nativas. Em 2000, 43\% da terra era controlada por empresas estrangeiras. Por último, Botsuana, outro país que foi protetorado britânico, o papel dos líderes tradicionais foi substituído por comissões fundiárias descentralizadas responsáveis pelo reconhecimento da posse e do uso da terra (Herbst, 2000).

Tabela 10 - Propriedade da terra nos não-PMDs sem guerra civil

\begin{tabular}{llll}
\hline País & $\begin{array}{l}\text { Propriedade } \\
\text { Privada }\end{array}$ & $\begin{array}{l}\text { Propriedade } \\
\text { Estatal }\end{array}$ & $\begin{array}{l}\text { Reconhecimento } \\
\text { Explícito do } \\
\text { Mandato } \\
\text { Costumeiro }\end{array}$ \\
\hline Gabão & $\begin{array}{l}\text { Sem guerra } \\
\text { Civil } \\
\text { Existe } \\
\text { Sem conflitos } \\
\text { menores }\end{array}$ & Não & Não \\
$\begin{array}{l}\text { Existe } \\
\text { Cabo Verde }\end{array}$ & Significante & Sim \\
$\begin{array}{l}\text { Maurício } \\
\text { Namíbia } \\
\text { Seicheles } \\
\text { Suazilândia } \\
\text { Zimbábue }\end{array}$ & Significante & Existe & Sim \\
\hline
\end{tabular}

Fonte: Herbst (2000), elaboração própria. 
A participação cada vez maior de líderes tradicionais em funções geralmente atribuídas ao Estado mostra, como já dito, uma clara tentativa de africanizar as burocracias sem, contudo, tornar indígenas as instituições de governança. Também neste grupo de Estados, a necessidade de construir um aparato coeso de poder fez com que os chefes de Estado buscassem acomodar ou incorporar as fontes concorrentes de autoridade, isto é, os líderes tradicionais. Tal fato, contudo, pode gerar dúvidas na população sobre quem efetivamente governa, o que pode ser a origem de tensões políticas que em última medida pode escalar em um conflito armado. Uma das implicações diretas que as políticas de supressão ou incorporação das autoridades tradicionais geraram na autoridade estatal foi a construção do juízo que as populações fazem sobre qual o nível em que as leis e as decisões devem ser feitas e quem deve fazê-las.

Apesar de a opinião pública nesses países ser tão mutável quanto em qualquer outro lugar do mundo, parece que neles há uma tendência ao consenso sobre tais pontos. Além do que a legislação prevê, o entendimento da população sobre as prerrogativas dos governos central e local, dos líderes tradicionais e até mesmo dos membros da comunidade podem ser fontes de desentendimento na estrutura e assim culminar em sobreposição de autoridades e em um juízo por parte das populações que potencialmente não reflete a realidade da distribuição das responsabilidades entre os agentes públicos estatais ou não-estatais. No entanto, a situação dos não-PMDs pacíficos neste sentido é muito mais clara do que nos PMDs que nunca passaram por guerra civil ou conflito nãoestatal.

Em ambos os grupos de países, a maior parte da população entende, por exemplo, que a cobrança do imposto de renda deve ser feita por agentes do Estado e, mais especificamente, do governo central. Neste ponto, a parcela mais baixa da população que atribui tal responsabilidade ao governo central foi em Cabo Verde, uma possível consequência de sua natureza insular e da distribuição de sua população entre nove das dez ilhas do arquipélago. Em alguns casos, as repartições públicas do Estado e das entidades locais acabam confundindo-se gerando assim uma percepção distinta da realidade. No tocante às disputas locais, o cenário é mais heterogêneo e já apresenta algumas diferenças importantes entre os países. Em Botsuana e Zimbábue, por exemplo, a maior parte da população atribui a responsabilidade de solucionar as disputas locais aos agentes públicos não-estatais, especificamente nos líderes tradicionais. Em Cabo Verde e na Namíbia, a percepção é de que tais resoluções devem partir dos agentes estatais, 
estando a opinião pública dividida entre atribui-la ao governo central ou local. Por fim, a alocação da terra (assunto que remeteu a esta discussão) mostra que há apenas discrepâncias e falta de consenso no Zimbábue. Enquanto nos outros três países a população entende que tal tarefa pertence ao Estado, neste a situação não é em nada clara para a população: quase metade entende tal feito é de responsabilidade dos líderes tradicionais enquanto uma parcela um pouco menor atribui-o ao governo central.

Tabela 11 - Responsabilidade Primária de Elementos da Governança do Estado nos PMDs pacíficos ${ }^{154}$

\begin{tabular}{|c|c|c|c|c|c|c|c|c|c|c|c|c|}
\hline \multirow{2}{*}{ País } & \multicolumn{4}{|c|}{ Alocação de Terras (\%) } & \multicolumn{4}{|c|}{ Imposto de Renda (\%) } & \multicolumn{4}{|c|}{ Disputas Locais (\%) } \\
\hline & $\mathrm{GC}$ & GL & LT & $\mathrm{MC}$ & $\mathrm{GC}$ & GL & $\mathrm{LT}$ & $\mathrm{MC}$ & $\mathrm{GC}$ & GL & $\mathrm{LT}$ & $\mathrm{MC}$ \\
\hline \multicolumn{13}{|l|}{ Gabão } \\
\hline \multirow{2}{*}{$\begin{array}{c}\text { Botsuana } \\
\text { Cabo } \\
\text { Verde }\end{array}$} & 38,0 & 34,5 & \multirow[t]{2}{*}{24,5} & 1,7 & 72,9 & 13,2 & \multirow[t]{2}{*}{2,9} & 0,8 & 10,5 & 7,7 & 75,3 & 5,7 \\
\hline & 17,8 & 71,5 & & 2,2 & 52,0 & 38,5 & & 1,4 & 30,6 & 46,4 & & 13,0 \\
\hline \multicolumn{13}{|l|}{ Maurício } \\
\hline \multirow{4}{*}{$\begin{array}{c}\text { Namíbia } \\
\text { Seicheles } \\
\text { Suazilândia } \\
\text { Zimbábue }\end{array}$} & 30,7 & 41,9 & \multirow[t]{3}{*}{23,3} & \multirow[t]{3}{*}{2,5} & 64,8 & 22,9 & \multirow[t]{3}{*}{5,4} & \multirow[t]{3}{*}{1,6} & 26,8 & 37,9 & \multirow[t]{3}{*}{22,4} & \multirow[t]{3}{*}{8,3} \\
\hline & & & & & & & & & & & & \\
\hline & & & & & & & & & & & & \\
\hline & 30,9 & 18,9 & 45,2 & 2,2 & 63,7 & 25,1 & 3,7 & 1,1 & 12,6 & 21,7 & 52,8 & 10,4 \\
\hline
\end{tabular}

Fonte: Afrobarometer (2009b; 2009c; 2009d), elaboração própria.

De modo geral, este cenário é bastante mais claro do que nos PMDs pacíficos, o que ajuda a justificar os níveis mais altos de autoridade estatal nestes países. O menor desentendimento pela população sobre a distribuição das responsabilidades mostra que o Estado é também mais efetivo e presente assim como sua resiliência é sinal da força do controle que ele tem na vida da população. Seja por causa da experiência histórica de Estados e instituições políticas mais complexas, seja porque o Estado de fato é forte e presente na vida da população, o que se vê é que também neste grupo de países o questionamento ao governo é diferente do questionamento às instituições e à estrutura estatal. Mesmo no Zimbábue, onde o presidente Robert Mugabe governa desde a independência do país, a oposição ainda busca participar do jogo político e da disputa pelo poder dentro das regras do Estado, mesmo sabendo que elas serão flagrantemente violadas e desrespeitadas pelo presidente. Esta é uma situação bastante semelhante à da

\footnotetext{
${ }^{154}$ Vide nota 102, página 140.
} 
Namíbia e à de Botsuana. Em ambos os casos, os partidos que levaram os países à independência são os únicos que os governaram, graças a sucessivas vitórias eleitorais. ${ }^{155}$

\subsection{Considerações finais}

Aplicando os testes efetuados com os PMDs que nunca tiveram guerra civil e conflitos não-estatais ao grupo de países analisados neste capítulo, pode-se chegar à conclusão de que também nestes a paz é devida à força da estrutura, isto é, das instituições estatais, que se sobrepõe aos incentivos para que os agentes políticos do Estado peguem em armas para tomá-lo. Destarte, o Estado em si não é questionado significativamente pelos atores políticos e, quando o foi, tratou de incorporar as fontes concorrentes de autoridade em seu aparato de modo a fortalecer sua autoridade sobre seu território. Tais testes justificaram, inclusive, os maiores níveis que estes têm em autoridade estatal não apenas no agregado, mas também nas três componentes que constituem tal variável (ausência de violência política e terrorismo, nomocracia e eficácia da governança). Estes Estados indicam o mesmo padrão sugerido pelos PMDs pacíficos que foram analisados no capítulo anterior: a indigenização da política e das instituições estatais favorecem a autoridade estatal (e assim evitam conflitos) uma vez que permite a capilarização da presença do Estado e influencia o padrão de retornos decrescentes em escala da projeção do poder e da consolidação da autoridade estatal sobre a distância. Isto é, projetar a autoridade e expandir a estrutura estatal é mais rentável nestes Estados, mesmo onde a geografia política não for favorável para tanto.

Além disso, se no final do capítulo anterior preocupou-se em dizer que nem tudo são flores nos PMDs pacíficos e que eles passaram por crises institucionais, o mesmo tipo de alerta é necessário para os não-PMDs que nunca passaram por guerra civil ou conflitos não-estatais. Desses oito países, especificamente Namíbia, Botsuana e Zimbábue apresentam ainda alguns desafios ligados à resiliência do Estado e à existência de uma economia paralela que, paradoxalmente, só se mantém devido à existência do Estado. Um viajante que se aventurar a atravessar por terra suas fronteiras irá se deparar com uma série de irregularidades e ilegalidades que variam desde a aparente ausência de leis de trânsito e regulamentação de meios de transporte à aparente ausência de qualquer lei ou

\footnotetext{
155 Por causa disso, é bastante raro (se é que é possível) encontrar algum estudioso que classifique o Zimbábue como democrático. Por outro lado, apesar de usualmente se classificar Botsuana como um país democrático, sua história levanta dúvidas sobre o fato de o PDB apenas realizar as eleições devido à certeza da vitória, tal como afirmam Alvarez, Cheibub, Limongi e Przeworksi (1996).
} 
respeito a marcas e patentes. Isto é uma realidade não apenas nas áreas mais afastadas e de difícil acesso para o Estado, mas também nas capitais Harare e Gaborone e outros grandes centros urbanos como Bulawayo, Gweru e Francistown. ${ }^{156}$

Além disso, há a impressão de que o Estado fomenta a economia paralela e informal. As carcomidas instalações dos postos de fronteira neles e toda a burocracia e taxas a serem pagas para a obtenção do visto de entrada passam a impressão de que o país de ingresso pouco interessado está em saber quem o viajante é e se ele pode ser um imigrante irregular ou representar algum risco à segurança nacional. A preocupação maior dos agentes de fronteira seria, na verdade, a arrecadação dos dólares que pagam a obtenção do visto do país de entrada. Além disso, um outro aspecto interessante diferencia Namíbia e Botsuana do Zimbábue. Enquanto o trânsito é relativamente livre e tranquilo nas rodovias dos dois primeiros, impressiona a quantidade de bloqueios e blitz policiais no segundo que controlam não o fluxo de automóveis, mas os indivíduos que viajam. Mesmo assim, o Estado continua existindo e suas instalações ainda representam a autoridade de um Estado cujos cidadãos e viajantes têm medo de desafiar.

\footnotetext{
${ }^{156}$ Isto é uma realidade em menor grau na Namíbia.
} 


\section{Reconstrução da autoridade como solução e prevenção de conflitos}

Nos capítulos anteriores, afirmou-se que a autoridade estatal e o desenvolvimento têm dinâmicas próprias e também que a primeira foi a responsável pela existência ou prevenção de conflitos intraestatais na África Subsaariana. Um dos maiores desafios para comprovar tal afirmação é justamente o fato de que há países (oito, para ser preciso) em que autoridade e desenvolvimento apresentaram correlação alta e positiva entre elas. À primeira vista, tal fato pode corroborar com a lógica da paz liberal de que não é possível haver desenvolvimento onde não houver estabilidade e que a segurança é frágil se não houver desenvolvimento. Seguindo esta lógica que já foi desafiada anteriormente neste trabalho, o fim de um conflito traria as condições necessárias e desejáveis para o desenvolvimento do país onde ele teria ocorrido e, ao mesmo tempo, seu desenvolvimento diminuiria os incentivos de stakeholders a recorrer às armas para atingir seus objetivos. Assim sendo, este derradeiro capítulo pretende primeiro confirmar que é a autoridade - e não o desenvolvimento - a variável que causará a paz ou a guerra intraestatais, mesmo esta tendo alta e positiva correlação com aquele. O segundo objetivo, portanto, não poderia ser outro que não analisar a relação entre essas duas variáveis e demonstrar que embora tenham dinâmicas distintas na maioria dos casos, aqui o fortalecimento da autoridade estatal é de vital importância para o desenvolvimento.

Este capítulo aborda os casos que poderiam ser entendidos como contrafatuais justamente por apresentarem casos com evolução nos níveis de desenvolvimento combinados com processos de pacificação de conflitos ou com a solidificação da paz onde ela já existia. Mesmo que no período analisado tais países sejam minoria, eles são casos importantes, pois ou são representativos dos mais importantes e sangrentos conflitos que a África pós-colonial conheceu ou converteram-se em fontes de estabilidade e democracia. Apenas oito países da África Subsaariana tiveram correlações altas e positivas entre autoridade e desenvolvimento e somente metade deles passou pela falência estatal e o consequente conflito intraestatal no período analisado. Além disso, seis deles compunham a lista dos PMDs durante o período e continuam a figurar nela ainda hoje. A tabela 1 mostra quais são esses países e os divide de acordo com a ocorrência ou não de guerra civil e conflitos não-estatais entre 1996 e 2011. Ela também apresenta o ano em que ingressaram em dita categoria. 
Tabela 12 - Países com correlação alta e positiva entre Autoridade e Desenvolvimento entre 1996 e 2011157

\begin{tabular}{lcll}
\hline $\begin{array}{l}\text { COM CONFLITOS } \\
\text { NO PERÍODO }\end{array}$ & PMD & $\begin{array}{l}\text { SEM CONFLITOS NO } \\
\text { PERÍODO }\end{array}$ & PMD \\
\hline $\begin{array}{l}\text { Angola } \\
\text { República do Congo }\end{array}$ & $1994^{158}$ & $\begin{array}{l}\text { Djibuti } \\
\text { Libéria }\end{array}$ & $\begin{array}{l}\text { Gana } \\
\text { Ruanda }\end{array}$ \\
\hline
\end{tabular}

Fonte: Uppsala Conflict Data Program (2016) e UNCTAD (2013), elaboração própria.

Mesmo com esta divisão e curiosa paridade no número de casos, este capítulo terá foco nos países que estiveram em guerra civil 1996 e 2011 (independentemente da data de início) e destarte tem como objetivo demonstrar que a causa das guerras civis das quais foram palco tiveram como causa as variações e os baixos níveis de autoridade estatal (e não o subdesenvolvimento) e também asseverar que a reconstrução do pós-guerra teve sucesso por causa do seu foco nas instituições e na consequente recuperação da autoridade estatal. Assim, pretende-se demonstrar que o sucesso em pôr fim a um conflito em andamento e evitar o surgimento de novas guerras civis nestes países deveram-se às políticas voltadas para o fortalecimento das instituições estatais e sua autoridade.

Os conflitos pelos quais Angola, República do Congo, Libéria e Ruanda passaram parecem, à primeira vista, bastante diferentes e, por isso, de difícil comparação. No entanto, as histórias dos conflitos e, principalmente, as políticas adotadas nesses países para pôr termo às guerras civis e garantir a estabilidade política mostram que tais casos têm muito em comum. Primeiro, eles são representativos do mesmo fenômeno. Todos eles possuíam o que Acemoglu e Robinson (2012) chamaram de "instituições extrativas" e acabaram caindo em guerras civis e falência estatais. Foram todos assolados por uma guerra civil que tinha como prêmio para o vencedor o controle das instituições estatais e, por isso, foram conflitos de caráter político em que se pode até mesmo afirmar a natureza clausewitziana desses conflitos ${ }^{160}$. Segundo, não apenas os quatro países estavam nas

${ }^{157}$ Os países que não têm um ano indicado ao lado não são da categoria PMD. São eles a República do Congo (Congo-BR) e Gana.

${ }^{158}$ Com a aprovação da resolução da Assembleia Geral da ONU A/RES/70/253 de 12 de fevereiro de 2016, Angola deixará de ser um dos PMDs cinco anos após a aprovação da mesma.

${ }^{159}$ Com a aprovação da resolução da Assembleia Geral da ONU A/RES/68/18 de 04 de dezembro de 2013, a Guiné Equatorial deixará de ser um dos PMDs cinco anos após a aprovação da mesma.

${ }^{160}$ Esta afirmação está longe de ser consensual. Numericamente, é provável que haja mais estudos questionando do que afirmando a natureza clausewitziana dos conflitos na África Subsaariana. Especificamente, Isabelle Duyvesteyn (2005) advoga em favor do reconhecimento de tal característica nos conflitos daquela região e toma a Libéria (que recebe atenção neste capítulo) e a Somália como estudos de caso. 
mesmas categorias propostas neste estudo de autoridade e desenvolvimento como também apresentam altas e positivas correlações entre ambas as variáveis. Além disso, o período entre 1996 e 2011 representa um tempo de fim de conflitos e reconstrução e consolidação das instituições estatais. Neste sentido, não apenas estes países apresentaram evoluções significativas em seus níveis de autoridade estatal, como também foram os que mais cresceram em tal indicador ${ }^{161}$. Além disso, é digno de nota o fato de que tais países estavam entre os cinco que mais evoluíram neste período no combate à violência política, um dos indicadores que compõem a variável autoridade ${ }^{162}$.

A existência de diferenças também favorece a comparação entre os casos. O primeiro fator neste sentido é que os casos devem ser distintos em variáveis chave, o que pode incluir os resultados dos processos comparados. Neste ponto, já foi dito que não apenas os quatro Estados em questão puseram termo às guerras que viviam e assumiram caminho de consolidação da paz no período analisado, mas também melhoraram muito seus níveis de autoridade. A diferença, portanto, reside no fato de que não houve desempenhos semelhantes nos outros indicadores que compõem o índice de autoridade estatal. Apenas Ruanda e Libéria tiveram bons desempenhos nos três indicadores. Enquanto estes são, respectivamente, o primeiro e o terceiro que mais cresceram em termos de eficácia da governança, a República do Congo teve apenas o $18^{\circ}$ melhor desempenho do período enquanto e Angola, o trigésimo, estando em 2011 pior do que em 1996 neste quesito $^{163}$. Algo semelhante acontece com o império da lei. Novamente, Angola e República do Congo tiveram desempenho fraco e muito inferior aos de Ruanda e Libéria, tendo respectivamente o nono e décimo-nono desempenhos neste indicador. Os gráficos 5, 6, 7 e 8 mostram essas evoluções.

\footnotetext{
${ }^{161}$ Ruanda e Libéria encabeçam a lista enquanto Angola tem o quarto melhor desempenho no indicador. República do Congo e Moçambique ficam para trás neste quesito, mesmo tendo, respectivamente, o décimo e o décimo quinto melhores desempenhos para o período analisado.

${ }^{162}$ Serra Leoa é o quinto país que completa tal grupo. Moçambique teve apenas o $18^{\circ}$ melhor desempenho. ${ }^{163}$ Entre 1996 e 2000, Angola sofreu uma significativa deterioração neste quesito devido à tensão trazida pela guerra naqueles anos. Apesar dos esforços para a recuperação e das melhorias neste indicador desde então, estes ainda não haviam sido suficientes para recuperar o nível pré-1996.
} 
Gráfico 5 - Evolução da autoridade estatal entre 1996 e 2011 (casos selecionados)

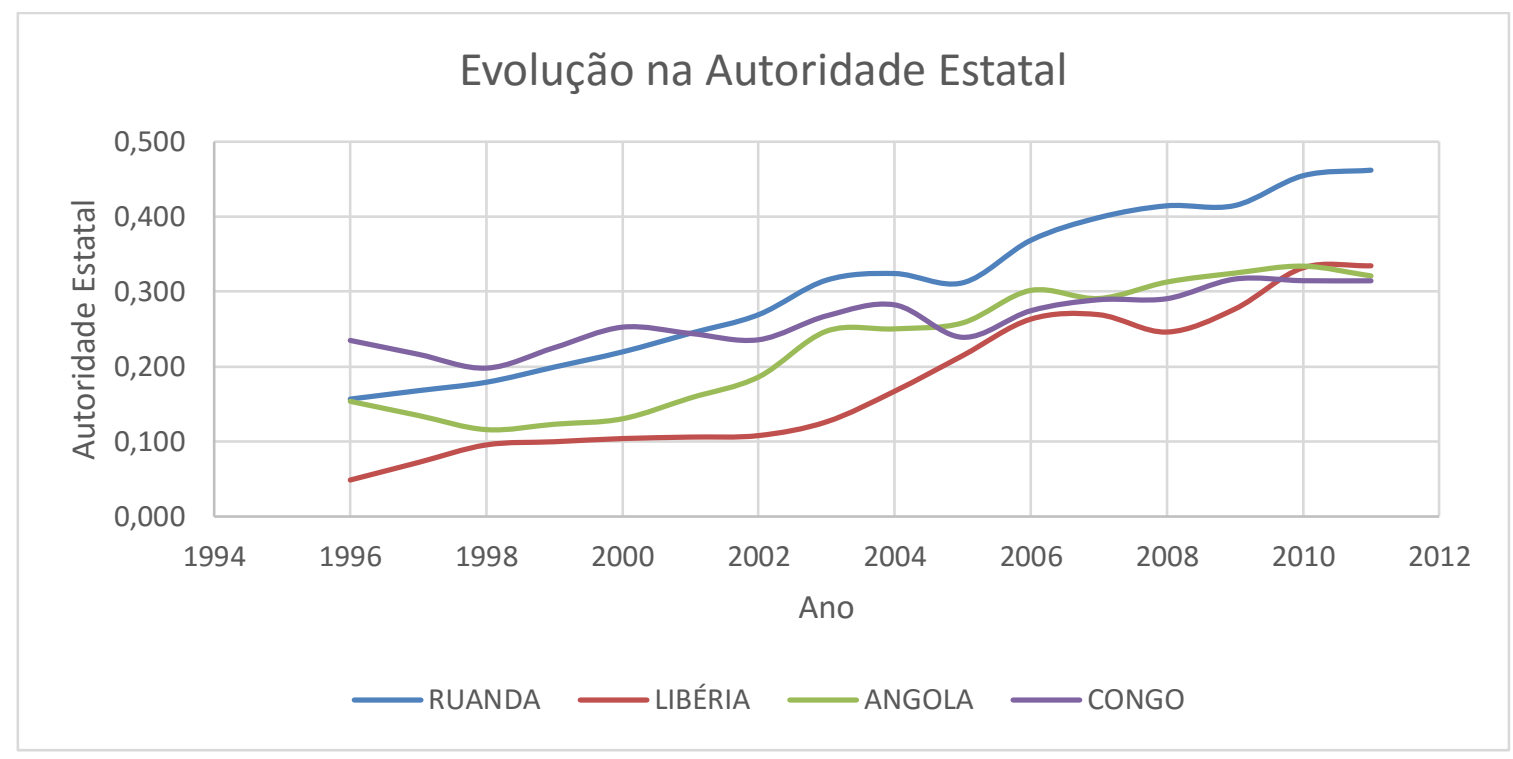

Fonte: Worldwide Governance Indicators (2014), elaboração própria.

Gráfico 6 - Evolução no indicador "ausência de violência política/terrorismo" entre 1996-2011 (casos selecionados)

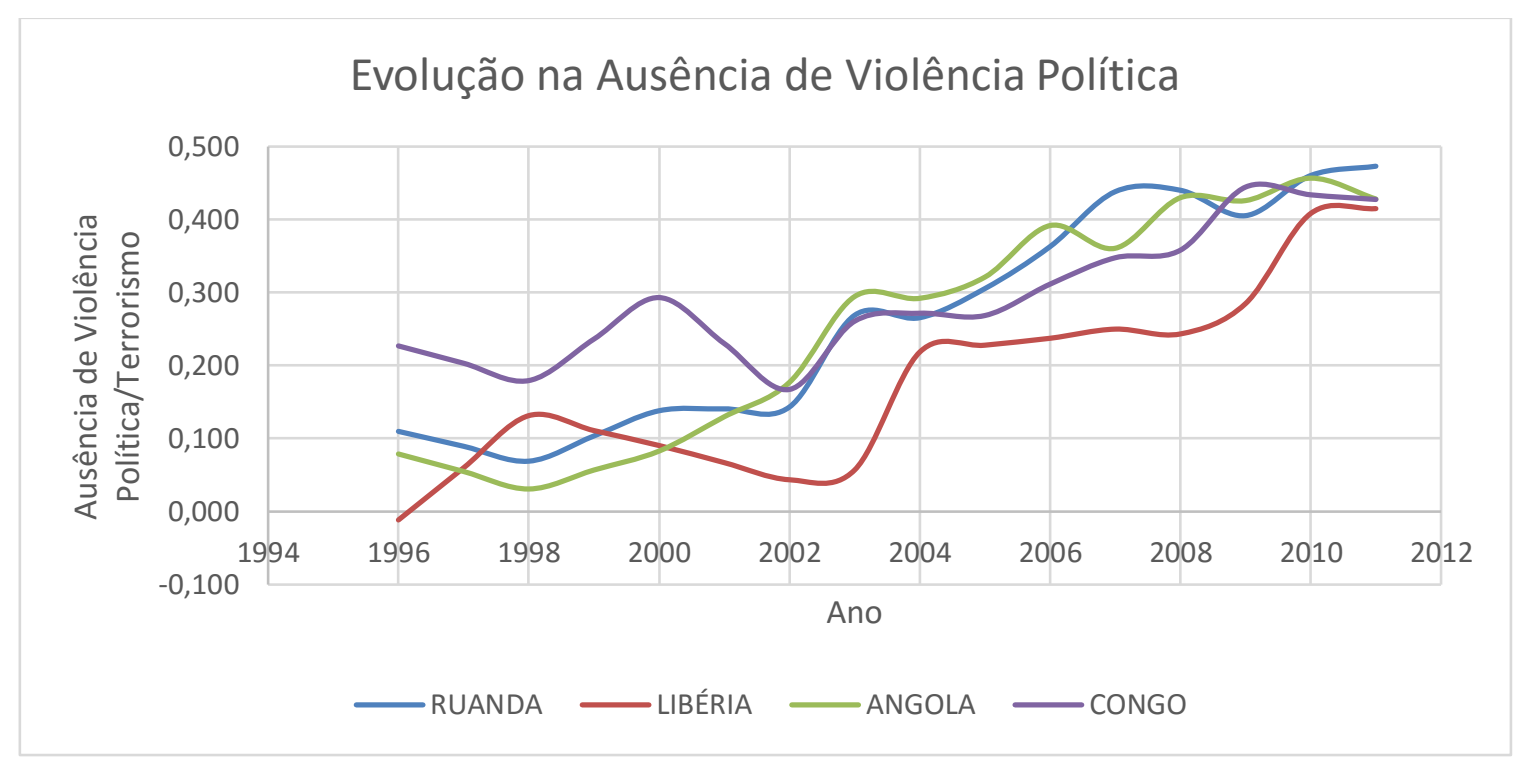

Fonte: Worldwide Governance Indicators (2014), elaboração própria. 


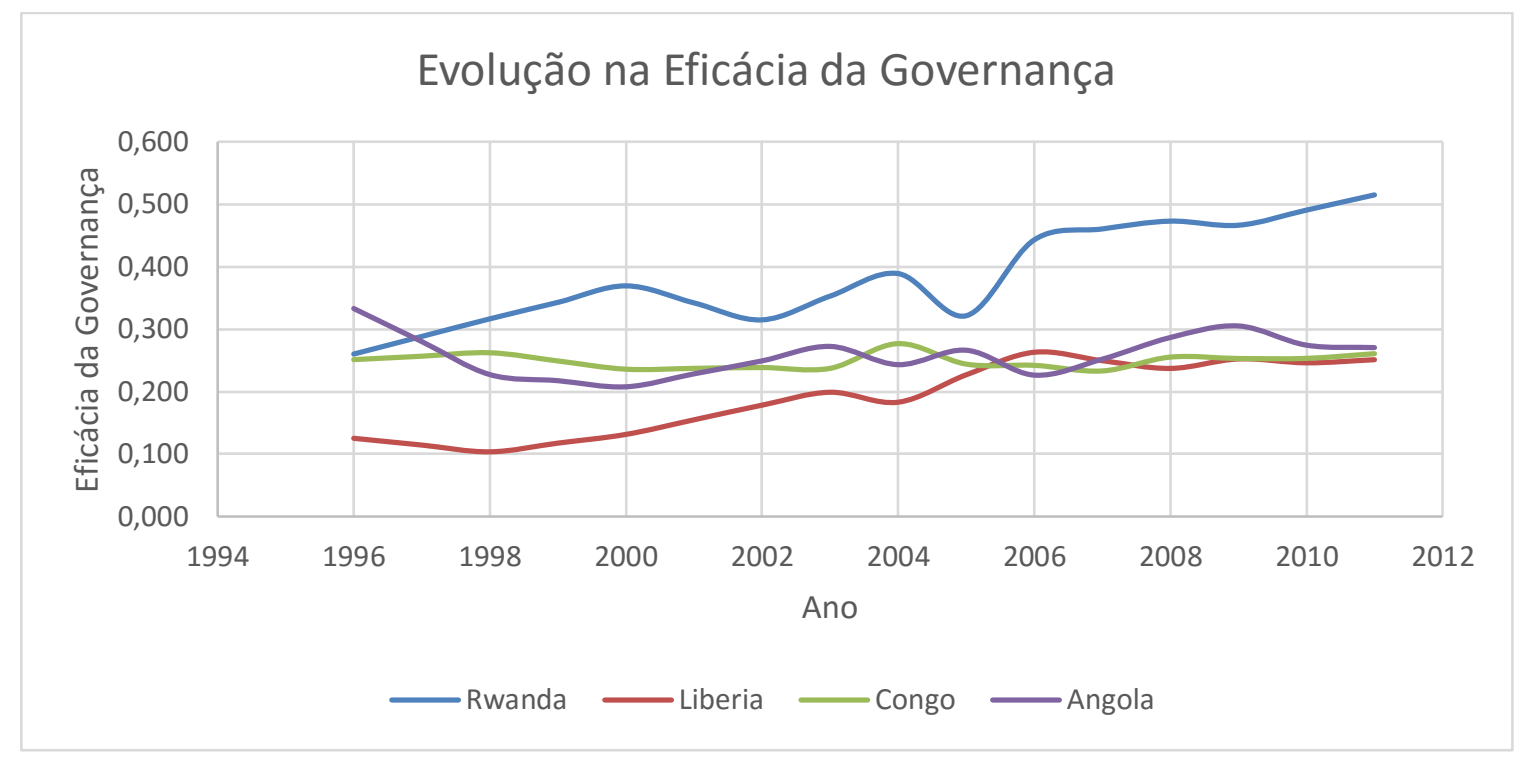

Fonte: Worldwide Governance Indicators (2014), elaboração própria.

Gráfico 8 - Evolução da Nomocracia 1996-2011

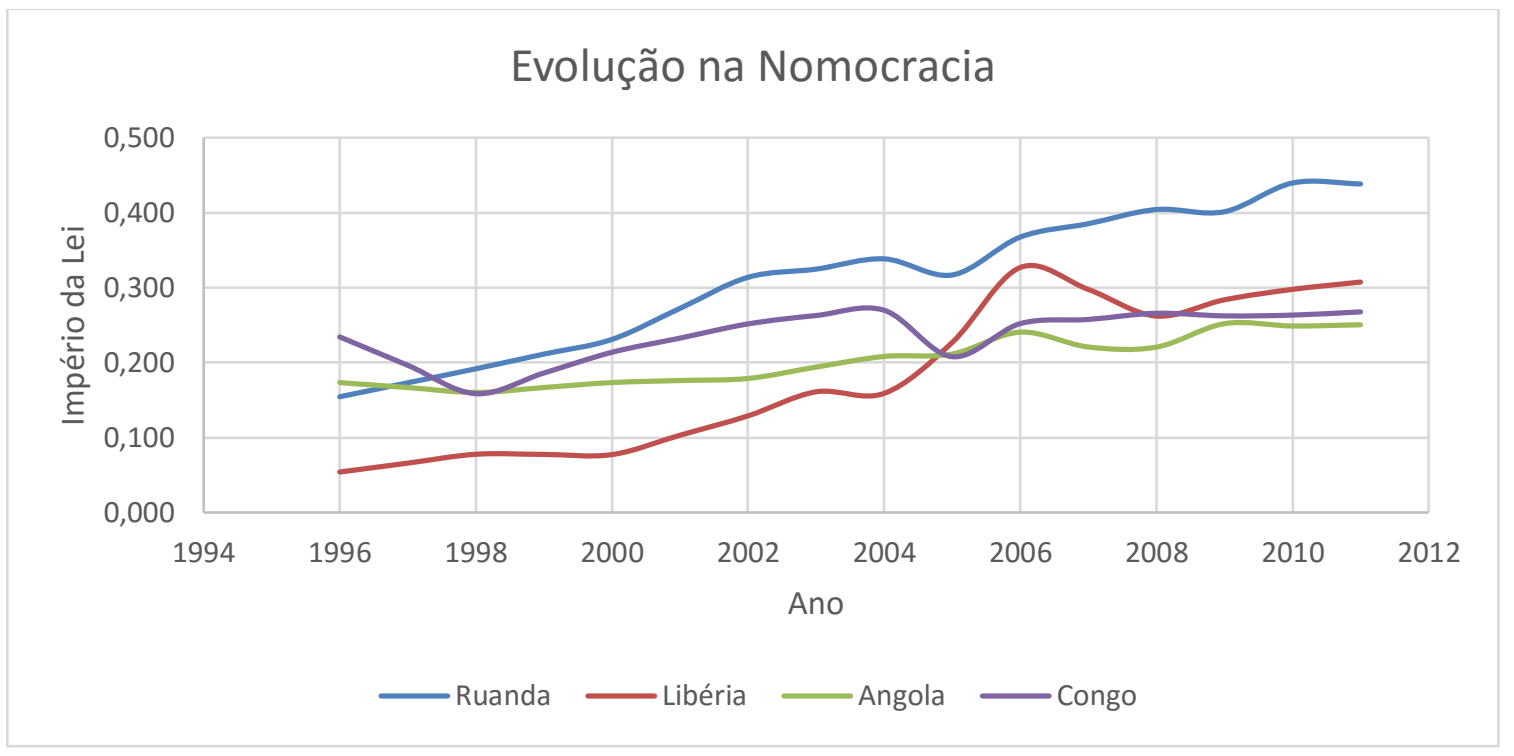

Fonte: Worldwide Governance Indicators (2014), elaboração própria.

Além dos dados expostos acima, há algumas diferenças importantes na origem e na condução do conflito e na reconstrução do país que permitem expor algumas particularidades nos casos, principalmente no que tange aos interesses dos atores e suas próprias ações. A primeira particularidade que se destaca é a questão da duração dos conflitos. A Guerra Civil Angolana perdurou por 27 anos (desde a independência do país 
em 1975 até a morte de Jonas Savimbi, líder da UNITA, em 2002). A República do Congo teve dois curtos momentos de guerra civil durante a década de 1990, ambos ligados a disputas eleitorais. Também a Libéria passou por duas guerras civis na última década do século XX, que transbordaram e tiveram efeitos perversos em Serra Leoa, seu vizinho mais próximo. Além do efeito de spill over que Ruanda provocou sobre Burundi, sua guerra civil de 1991 a 1994 foi marcada pelo sangrento genocídio que vitimou quase um milhão de pessoas.

Os caminhos tomados para a resolução do conflito nesses quatro casos também foram diferentes e assim, também levaram a resultados distintos. Primeiro, é digno de nota que a Libéria foi o único país deste grupo a receber uma profunda intervenção internacional que foi responsável não apenas pela solução do conflito, mas também pela a reconstrução do país. Ela é, talvez, o principal caso de sucesso da aplicação da paz liberal em países africanos. Por outro lado, Angola e Ruanda são casos em que a intervenção internacional ou inexistiu ou teve um retumbante fracasso. Não à toa, em ambos os países a guerra teve seu final com a completa derrota de uma das partes. $\mathrm{Na}$ República do Congo, o conflito arrastou-se com baixa intensidade por mais quatorze meses após a tomada do poder por uma das partes beligerantes.

Para os quatro casos, contudo, ainda fica a questão. O que gerou seus conflitos, isto é, o que foi afinal capaz de enfraquecer a autoridade do Estado a tal ponto que suas instituições vieram a falir? Neles, a criação de milícias, a execução de atentados contra alvos civis e militares e golpes de Estados foram características marcantes e presentes antes da eclosão. Ademais, também a percepção de que os serviços civis não eram independentes de pressões políticas bem como a falta de confiança na justiça também são questões relevantes na eclosão da guerra, uma vez que torna praticamente impossível o jogo político por outros meios que não a conquista pela força do aparato estatal e a garantia de liberdades mínimas aos indivíduos.

\subsection{Autoridade estatal como variável-chave}

Tal como Ruanda e Libéria (discutidas no capítulo 2), a guerra civil de Angola desempenhou papel crucial na fundação do estado e na consolidação de suas instituições. A diferença, no entanto, é que enquanto naqueles casos a guerra fragilizou as instituições e danificou a autoridade estatal existente, em Angola ela acabou por dificultar a própria criação de instituições pós-coloniais ou até mesmo a adaptação de instituições coloniais 
após a independência do país. ${ }^{164}$ A guerra civil que eclodiu poucos meses antes da independência do país perdurou por 27 anos e deixou profundas consequências no país. Quando a guerra terminou, estimava-se que ainda havia aproximadamente 5 milhões de minas terrestres ativas espalhadas pelo imenso território o que dificultou o retorno dos civis para seus locais de origem. O tamanho de seu território e a distribuição de sua população foram apenas empecilhos adicionais a uma solução militar para a guerra (Herbst, 2000).

Em janeiro de 1975, os líderes das três principais frentes de libertação nacional que lutavam pela independência do país assinaram o Acordo de Alvor, no qual definiram a data oficial da independência do país (11 de novembro daquele ano) e concordaram em montar um governo provisório ocupado por todos eles. Contudo, o mesmo fora violado menos de dois meses após sua assinatura com o ataque do MPLA à base da UNITA na capital Luanda, o que deu início à guerra. Por causa disso, quase minguaram os planos de independência do país já que Portugal chegou a considerar a possibilidade de retomar o controle direto da colônia em virtude da onda de violência que se instalava. Tal onda não cessou nem mesmo com as duas partes concordando em retornar aos termos do Acordo de Alvor que previa, entre outras coisas, a fusão dos braços armados das três frentes de libertação nacional e a consequente criação do exército nacional angolano.

Foi neste contexto que Portugal reconheceu o MPLA como o único interlocutor viável para negociar a transição para a independência angolana. Por mais que o movimento houvesse firmado o acordo com a UNITA e o Frente Nacional para a Libertação de Angola (FNLA) para a construção conjunta do governo pós-independência, havia a percepção de que apenas aquele possuía um projeto de nação e não estava apoiado em identidades sectárias ou subnacionais. De fato, a Angola que fazia sua transição para a independência não representava uma nação, mas sim uma sociedade bastante fragmentada e suas divisões originavam-se e eram mantidas com base no sistema português que impunha barreiras e restringia o acesso à educação. Desta forma, a grande maioria da população via-se impedida de crescer tanto econômica quanto socialmente (Visentini, 2012).

164 Outra diferença importante entre os três é que Angola apenas entrou para a categoria dos PMDs em 1994, oito anos antes de a guerra terminar oficialmente. Libéria entrou para a categoria em 1990, no ano seguinte ao início de sua primeira guerra civil enquanto Ruanda já estava em tal categoria desde 1971, quando ela foi criada. 
Essa divisão entre brancos, mestiços, assimilados e povos indígenas não era, contudo, a única que assolava a sociedade que estava por se emancipar do jugo colonial. A demografia do país reforçava uma série de outras divisões uma vez que Angola tinha um centro de maior densidade demográfica na região de Luanda, na costa, e outro na região de Huambo, no centro do país. No restante, o território angolano é pouco povoado e as diferenças em termos de qualidade de vida e acesso à educação entre os ambientes urbano e rural eram gritantes (Herbst, 2000; Visentini, 2012). Além disso, a própria divisão étnico-linguística do país constituía num obstáculo importante para o sucesso de qualquer projeto nacional. Não à toa, FNLA e UNITA usaram principalmente esta última divisão para constituir suas bases (Chabal, et al., 2002; Malaquias, 2001; Serrano, 2009).

Se a situação já indicava que a escalada da violência entre os três movimentos era possível, a proclamação simultânea e a consequente reivindicação do governo e da representação oficial do Estado apenas fez cumprir a profecia ${ }^{165}$. À medida que as hostilidades entre os grupos aumentavam, a fome e a escassez também assolavam cada vez mais à população angolana e as partes chegavam a um impasse militar em que o (agora governo) MPLA controlava apenas o litoral do país, mesmo contando com o apoio de tropas cubanas, e conseguia financiar suas atividades com a renda advinda da exportação de petróleo. Por outro lado, a UNITA continuava recebendo apoio de vizinhos como a África do Sul e do então Zaire. Tal apoio não cessou nem mesmo após a formalização do Acordo de Lusaca em 1984, que previa que Pretória retiraria suas forças de Angola desde que esta não cedesse mais porto seguro à SWAPO, que lutava pelo fim do jugo sul-africano na Namíbia. A África do Sul desde o início do processo que culminou neste acordo rejeitou a agenda de negociações que incluía sua relação com a UNITA. Tanto para Pretória como para Kinshasa, "a longevidade do regime requeria um Estado angolano fraco e instável" (Malaquias, 2001, p. 22).

Ao que a guerra avançava, ficava cada vez mais claro para o regime do MPLA que a paz só viria via negociações com a UNITA. Foi tendo isto em mente que se assinou um acordo de paz em Lisboa, em maio de 1991, que previa a realização de eleições livres para meados de setembro do ano seguinte. O pleito aconteceu como previsto e deu vitória

\footnotetext{
${ }^{165}$ No dia 11 de novembro de 1975, Angola foi proclamada independente tal como previsto no Acordo de Alvor. Ao mesmo tempo, o MPLA proclamou a República Popular de Angola e a FNLA e a UNITA proclamaram a República Democrática de Angola. Apenas o primeiro foi reconhecido internacionalmente (Correia, 1991).
} 
no primeiro turno a José Eduardo dos Santos, líder do MPLA e então presidente do país, por $49,57 \%$ dos votos contra 40,07\% de Jonas Savimbi, líder da UNITA. Como nenhum dos candidatos havia obtido maioria absoluta, era necessária a realização de um segundo turno que, contudo, jamais aconteceu uma vez que Savimbi contestou os resultados daquele sufrágio. Tal situação praticamente anulou o acordo de paz do ano anterior e reabriu as hostilidades entre governo e UNITA que, em seu apogeu, chegou a controlar quase três quartos do território angolano (Koné, 2013; Lugan, 2013)

A sorte da UNITA começou a mudar, contudo, a partir de maio de 1993. O fim da Guerra Fria e a multiplicação das descobertas de campos petrolíferos em Angola fizeram com que os EUA retirassem seu apoio ao grupo rebelde, que entrou em declínio. Com o governo angolano retomando posições e revertendo a situação na guerra, a UNITA concordou com a assinatura do Protocolo de Lusaca em novembro de 1994, que estabelecia um cessar-fogo e o reconhecimento do resultado das eleições de 1992. Como o cessar-fogo nunca foi efetivamente implementado, uma série de sanções da ONU e da UE foram impostas contra a UNITA. Entre elas, o Conselho de Segurança da ONU impôs embargos petrolíferos e militares ao grupo rebelde e congelamento dos bens de Jonas Savimbi ${ }^{166}$. O grupo rebelde - fragilizado - acabou por sucumbir em 2002, quando Savimbi foi morto em combate, e rendeu-se pouco mais de um mês depois, em 30 de março daquele ano, o que permitiu ao governo angolano declarar oficialmente o fim da guerra civil. A exploração dos campos de petróleo que vinham sendo descobertos desde os anos 1990 auxiliou o desenvolvimento do país, combinado com o aumento da presença de investidores no país. Não à toa, é previsto que Angola deixe de ser um dos PMDs no ano de 2021.

Dos quatro países analisados neste capítulo, a República do Congo é a única que não fez parte da categoria dos PMDs. Adeptos da tese da fusão entre segurança e desenvolvimento alegariam que por isso ela foi a que teve a guerra civil de menor duração (1997-99). No entanto, sua história aponta para luta entre facções pelo poder do Estado que fora enfraquecido ao longo dos anos 1990, quando os processos de liberalização política e econômica foram implementados. Como já foi argumentado neste estudo, tais processos podem afetar diretamente a autoridade estatal e o Congo-Brazzaville parece ser mais uma amostra que confirma a regra.

\footnotetext{
${ }^{166}$ S/RES/1173 (1998) e S/RES/1176 (1998).
} 
Desde sua independência em 15 de agosto de 1960, o país foi marcado por instabilidade política e governos antidemocráticos. Nos seus primeiros 12 anos de história independente, dois golpes de Estado aconteceram (1963 e 1968) e a tentativa de outros dois fracassou (1966 e 1972). A estabilidade política e as tentativas de golpe só foram neutralizadas com a proclamação da República Popular do Congo, em 1970, quando o país se declarou marxista-leninista e instituiu regime de partido único. Isso não impediu, contudo, o assassinato do presidente Marien Ngouabi em 1977. Foi a ascensão de Denis Sassou Nguesso à presidência do país em 1979 que permitiu maior estabilidade ao país e uma taxa de crescimento econômico médio de 7,4\% entre 1980 e 1992 (ano em que deixou o poder), mas também uma taxa média de inflação de estratosféricos $67 \%$ ao ano. Ao que a inflação anual era mais ou menos constante, o alto crescimento econômico médio anual deveu-se a dois picos (1980 e 1988-89), ficando em torno de $2 \%$ no restante do período. Se a primeira metade da década de 1980 foi de relativo crescimento econômico e de melhorias sociais, a segunda metade foi de retrocesso nessas áreas (Girod, 1994; Yengo, 2006; International Monetary Fund, 2016).

Face às mudanças conjunturais dos anos 1980 e as tendências negativas da economia, Sassou Nguesso viu-se forçado a tomar medidas para garantir sua permanência no poder e a estabilidade do país. O ajuste estrutural promovido nos anos de 1985 e 1986 sob pressão do FMI e do Banco Mundial dirimiram alguns monopólios estatais na economia e garantiram um reescalonamento da dívida externa do país. Esta e outras medidas geraram uma série de descontentamentos dentre a população que chegou até mesmo a organizar uma greve geral em setembro de 1990. Com o Estado menor e as possibilidades cada vez menores de arrebanhar novos clientes políticos, Sassou Nguesso primeiro lançou mão de repressão política para assegurar-se no poder e garantir a estabilidade política do país. Tendo em vista que tal comportamento não foi eficaz, organizou a liberalização política do país e concordou com a realização de eleições multipartidárias. Foi exatamente aí que a situação política do país começou a se deteriorar de vez até culminar na guerra civil de 1997 (Magnusson \& Clark, 2005) ${ }^{167}$.

\footnotetext{
${ }^{167}$ Do fim dos anos 1980 até a realização das eleições em 1992, uma série de mudanças profundas foram feitas na política da República do Congo. À parte das eleições, talvez a mais significativa de todas tenha sido a realização da Conferência Nacional Congolesa que, entre outras coisas, desenhou uma nova constituição e reduziu drasticamente os poderes do chefe de Estado. Apesar de ter mantido Sassou Nguesso no poder até a realização das eleições, a Conferência havia reduzido as prerrogativas do presidente a funções meramente decorativas enquanto instituiu um governo interino liderado por André Milongo, um antigo oficial do Banco Mundial.
} 
As eleições de 1992 representaram uma mudança estrutural bastante importante na política congolesa. Eram as primeiras eleições (livres e multipartidárias) da história do país. No entanto, a insatisfação popular com os rumos políticos e econômicos do país eram tão grandes que puseram um fim aos 13 anos de governo do então presidente e principal responsável pelo processo de abertura política do país Denis Sassou Nguesso, que sequer foi ao segundo turno. Este foi disputado entre os oposicionistas Pascal Lissouba da União Pan-africana para a Democracia Social (UPADS) - que saiu vitorioso - e Bernard Kolelas do Movimento Congolês para a Democracia e Desenvolvimento Integral (MCDDI).

Enquanto presidente, Lissouba tratou de promover reformas econômicas liberalizantes que chegaram a melhorar substantivamente a situação econômica do país por meio de políticas de ajuste fiscal que harmonizou a economia nacional e que levou à desvalorização do Franco CFA (XAF) e implementou uma série de reformas nos setores petroleiro, financeiro e público. Como resultado dessas políticas, o saldo orçamental primário subiu mais de 11 pontos percentuais do PIB entre 1993 e 1995 ao passo que a parte do PIB não correspondente ao comércio de petróleo começou a se recuperar em 1995, após drástica queda no ano anterior (International Monetary Fund, 1996). É importante ressaltar também que tais melhorias não se restringiram apenas a orçamento, PIB e comércio exterior. Elas foram importantes também para alavancar as melhorias em recursos humanos no país ${ }^{168}$.

Apesar das melhorias sociais e econômicas pelas quais o país viria a passar, a instabilidade política começou justamente devido à sua abertura e à realização das eleições. Apesar de Lissouba ter ganho as eleições, ele teve dificuldades importantes para governar uma vez que o Partido Congolês do Trabalho (PCT) e o MCDDI aliaram-se e formaram maioria na Assembleia do país seguindo as eleições parlamentares de 1993. Tal fato em si não representa nenhuma anomalia política. O que foi problemático, contudo, foi que os três líderes dos três principais partidos das eleições de 1992 e 1993 organizaram e armaram milícias que disputavam áreas de influência no país, mas principalmente na capital Brazzaville. Estas disputas que seguiram até o fim de 1994 tiveram como estopim o ataque das milícias Ninja e Cobras (do MCDDI de Kolelas e do PCT de Sassou Nguesso, respectivamente) à milícia Cocoye (do UPADS de Lissouba).

\footnotetext{
${ }^{168}$ De acordo com o Índice de Recursos Humanos deste estudo. Vide Apêndice I.
} 
Ou seja, os derrotados na eleição presidencial uniram-se contra o vitorioso não apenas no parlamento, mas também nas armas e, mesmo depois de acalmada a situação, o governo do país fracassou em desarmar as milícias que, além de tudo, recebiam apoio de partes de outros conflitos da região.

Foi nesse clima de incerteza política que se começou a preparar as eleições presidenciais marcadas para julho de 1997. Suspeitando que Sassou Nguesso pudesse tentar dar um golpe de Estado, Lissouba ordenou que os Cocoye (sua milícia) se antecipassem e atacassem os Cobras (milícia de Sassou Nguesso). A violência logo envolveu também os Ninja e tomou conta da capital e arreadores, dando início à guerra civil da República do Congo. As primeiras tentativas de encerrar o conflito tiveram lugar no dia 11 de junho daquele ano, apenas 11 dias após o início dos combates entre os Cocoye e os Cobras. Nesse dia, Lissouba e Sassou Nguesso encontraram-se em Libreville, Gabão, mas falharam em encontrar pontos a serem negociados ou a encontrar uma saída para o conflito. O único acordo decorrente da reunião foi um cessar-fogo de quatro dias para que estrangeiros pudessem sair do país. Durante esse período, Lissouba visitou Ruanda, Uganda e Namíbia procurando apoio internacional e acusou os Cobras de receber suporte de apoiadores de Mobutu Sese Seko - que fora deposto da presidência do Zaire havia dois meses e ainda tentava recuperar sua posição ${ }^{169}$.

Numa outra tentativa de pôr fim à escalada da violência, o então presidente Lissouba ofereceu a Sassou Nguesso cinco ministérios para que ele e seus aliados ocupassem e apontou Bernard Kolelas para o cargo de primeiro-ministro. Com esta oferta, Lissouba pretendia trazer Sassou Nguesso e Kolelas - seus maiores rivais políticos - para fazer parte da instituição a que eles desafiavam e também permitir que estes tivessem acesso às benesses e recursos do Estado e assim pudessem distribui-las entre sua clientela política. Assim, as principais fontes de autoridade concorrentes ao Estado ocupariam parte da máquina estatal (ainda que sob o comando formal de Lissouba) e, portanto, teriam reduzidos seus interesses em combatê-las. O problema, contudo, é que apenas Kolelas aceitou a proposta enquanto Sassou Nguesso calculou que poderia ter maiores ganhos caso os Cobras continuassem a luta armada.

\footnotetext{
${ }^{169}$ Ao fazê-lo, Lissouba tentou angariar apoio de Laurent-Désiré Kabila, presidente do antigo Zaire e então República Democrática do Congo, e responsável pela derrocada de Mobutu Sese Seko.
} 
Tal recusa fez com que os Cocoye e os Ninjas se unissem contra os Cobras, envolvendo na luta armada assim as três maiores milícias e as forças de segurança do governo. No entanto, foram as forças externas que deram maior força aos Cobras de Sassou Nguesso. Em outubro de 1997, as Forças Aéreas Angolanas atacaram posições dos Cocoye (cujo líder financiava e apoiava a UNITA) e garantiram o controle dos Cobras na capital congolesa. Foi durante essa ofensiva que Lissouba foi retirado do poder e Sassou Nguesso voltou ao poder como presidente do país e, como uma de suas primeiras atitudes, incorporou os Cobras ao exército nacional. O presidente deposto, no entanto, organizou um governo no exílio e continuou a apoiar as milícias contrárias ao novo regime. O novo chefe de Estado continuou combatendo os Cocoye e os Ninja até dezembro de 1999, quando impôs a rendição às milícias e assinou um tratado de paz que - complementado com uma Lei de Anistia - pretendia desmobilizar e reintegrar excombatentes. Tal feito até deu alguma estabilidade política ao país. No entanto, a situação voltou a deteriorar-se em março de 2002 quando uma nova constituição foi aprovada em um referendo e Sassou Nguesso foi reeleito presidente. Nesse momento, milicianos que não haviam sido desmobilizados retomaram a violência no departamento de Pool, ao sul do país e que circunda o distrito onde fica a capital Brazzaville. A situação somente tornar-se-ia pacífica novamente em 17 de março de 2003, quando um acordo de cessação de hostilidades fora assinado. Ademais, é digno de nota o vocabulário utilizado nesse acordo: as partes estavam comprometidas com a "reabilitação da autoridade do Estado no departamento de Pool". ${ }^{170}$

Além das correlações e evoluções apresentadas no início desta seção, os quatro casos acima ilustram bem que se há alguma causalidade entre autoridade e desenvolvimento é no sentido de que o primeiro gera o segundo e que a causa principal da eclosão de suas guerras civis e de suas conseguintes falências estatais residem nos baixos níveis de autoridade estatal e não no subdesenvolvimento ou piora nos níveis de desenvolvimento estatal. Entre 1996 e 2011, os níveis de desenvolvimento desses países não entraram em tendência de queda sem que antes os níveis de autoridade estatal o fizesse. Além disso, a evolução do desenvolvimento neles somente atingiu crescimento mais acelerado quando a própria autoridade estatal voltou a crescer. Conforme demonstrado, as guerras civis de Ruanda, Libéria e República do Congo tiveram como a origem o enfraquecimento da estrutura estatal em relação à disposição de ação dos

\footnotetext{
${ }^{170}$ Accords de Paix et de cessation des hostilités dans le département de Pool, 17 de março de 2003.
} 
agentes. No primeiro, o conflito deveu-se mais à implantação paulatina do caos e o gradativo carcome da autoridade estatal levados a cabo por meio de uma série de atentados e assassinatos políticos que minaram a sensação de que o governo era capaz de garantir a ordem doméstica enquanto no segundo aproveitou-se da patologia institucional existente que permitiu o crescimento e superação dos incentivos ao conflito em detrimento dos inibidores de conflito. No último, o processo de abertura política do Estado e as consequentes eleições presidenciais e parlamentares foram responsáveis pela ruína da já fraca autoridade estatal daquele país. Além deles, a disputa pelo controle do Estado desde poucos meses antes da independência pôs em cheque a construção de instituições políticas robustas em Angola, que só pôde investir na autoridade estatal delas decorrentes após o fim do conflito. O que eles indicam, portanto, é que se o problema (a guerra civil e a falência estatal) ocorreu em decorrência da autoridade estatal, a solução também dela deve advir.

\subsection{Reconstrução da autoridade estatal como solução de conflitos}

É exatamente esse entendimento que pode ser encontrado em uma série de acordos de paz ou cessar-fogo que puseram termo ou ao menos paralisaram temporariamente um conflito civil. No que diz respeito aos casos desta seção, todos lançaram mão de tais mecanismos e dedicaram-lhes bastante atenção não apenas ao que determinaria o fim imediato das hostilidades (cessar-fogo), mas também se preocupavam com a garantia de que o Estado obtivesse o monopólio do uso da força, com o fortalecimento das forças de segurança do Estado e com a criação e execução de programas de desarmamento, desmobilização e reintegração (DDR) para os combatentes. Todos estes fatores compõem a estabilidade política de um país, garantindo a ausência de violência política e/ou terrorismo. Contudo, a atenção dedicada à eficácia da governança e ao império da lei ou não tiveram tanto espaço nesses tratados ou simplesmente não tiveram chances de ser implementados, a despeito da vontade das partes beligerantes em negociar também estes aspectos da reconstrução estatal, tal como mostra a tabela 13: dos 27 tratados firmados durante os períodos de conflito dos quatro países em questão, todos trataram sobre questões de estabilidade política, vinte sobre questões ligadas à efetividade da governança e apenas três sobre questões ligadas à nomocracia.

Tabela 13 - Escopo dos Acordos de Paz (casos selecionados)

\begin{tabular}{|lll|l|l|l|}
\hline País & Acordo & Data & \multirow{2}{*}{ Estabilidade Política (PV) } & Efetividade da Governança (GE) & Nomocracia (RL)
\end{tabular}




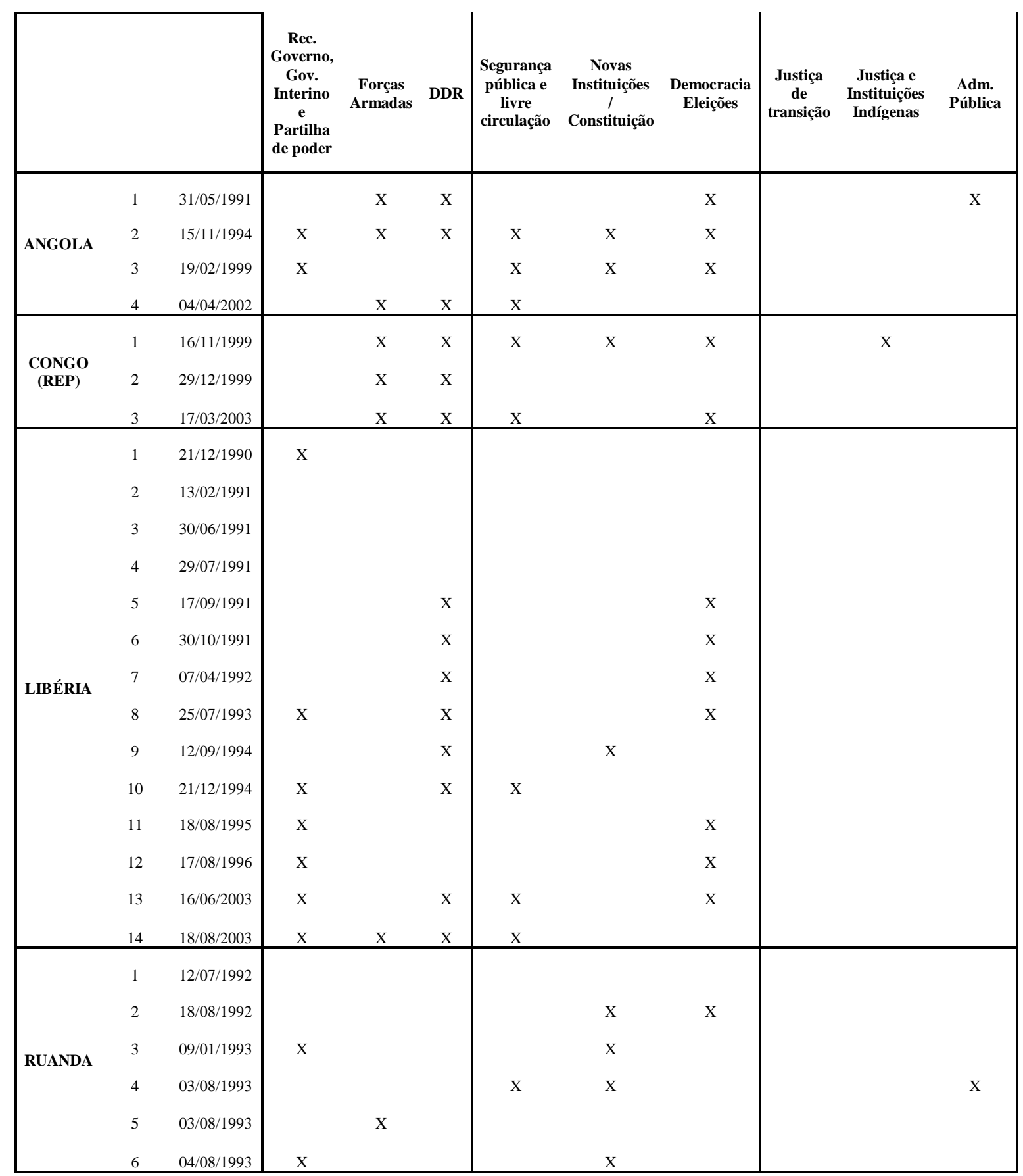

Fonte: U.N. Peacemaker (ONU, 2016), elaboração própria.

Legenda:

Angola 1 Acordos de Bicesse

Angola 2 Protocolo de Lusaka

Angola 3 Protocolo de Luanda

Angola 4 Acordo de Luena

Congo 1 Accord de cessation des hostilités em République du Congo

Congo 2 Accord de cessez-le-feu et de cessation des hostilités entre le Haut Commandement de la Force Publique et le Haut Commandement des Forces d'Autodéfense de la Résistance (FADR)

Congo 3 Accords de paix et de cessation des hostilités dans le département de Pool

Libéria 1 Banjul IV Agreement

Libéria 2 Lomé Agreement 
Libéria 3 Yamoussoukro I

Libéria 4 Yamoussoukro II

Libéria 5 Yamoussoukro III

Libéria 6 Yamoussoukro IV

Libéria 7 Final Communiqué of the ECOWAS Committee of Five on Liberia

Libéria 8 Cotonou Agreement

Libéria 9 Akossombo Agreement

Libéria 10 Accra Clarification

Libéria 11 Abuja Agreement to Supplement the Cotonou and Akosombo Agreements as Subsequently Clarified by the Accra Agreement

Libéria 12 Supplement to the Abuja Accord

Libéria 13 Agreement on Ceasefire and Cessation of Hostilities between the Government of the Republic of Liberia and Liberians United for Reconciliation and Democracy and the Movement for Democracy in Liberia

Liberia 14 Peace Agreement between the Government of Liberia, the Liberians United for Reconciliation and Democracy (LURD), the Movement of Democracy in Liberia (MODEL) and the Political Parties

Ruanda 1 The N'sele Ceasefire Agreement between the Government of the Rwandese Republic and the Rwandese Patriotic Front

Ruanda 2 Protocol of Agreement between the Government of the Republic of Rwanda and the Rwandese Patriotic Front on the Rule of Law

Ruanda 3 Protocol of Agreement on Power-sharing within the Framework of a Broad-based Transitional Government between the Government of the Republic of Rwanda and the Rwandese Patriotic Front

Ruanda 4 Protocol of Agreement between the Government of the Republic of Rwanda and the Rwandese Patriotic Front on Miscellaneous Issues and Final Provisions

Ruanda 5 Protocol of Agreement between the Government of the Republic of Rwanda and the Rwandese Patriotic Front on the Integration of the Armed Forces of the Two Parties

Ruanda 6 Peace Agreement between the Government of the Republic of Rwanda and the Rwandese Patriotic Front

Esta gritante diferença nada mais mostra do que uma hierarquia na agenda das negociações para pôr termo aos conflitos que assolaram esses quatro países e para reconstruir o Estado, tornando-lhe mais uma vez funcional. Este poderia ser um dos motivos que explica o fato de os quatro países desta seção terem apresentado muito mais melhorias no que diz respeito à ausência de violência política e terrorismo, isto é, estabilidade política, do que nos outros dois quesitos. Nos casos de Angola e República do Congo, essa lógica é facilmente compreendida devido ao fato de que tanto as dificuldades em construir o Estado no primeiro caso quanto o processo de falência do Estado no segundo caso foram devido à uma má acomodação das forças políticas lá presentes. Enquanto em Angola UNITA e MPLA lutaram desde alguns meses antes da independência do país para o controle das instituições coloniais que permaneceriam, na República do Congo a democratização do país após décadas de governo centralizado não acomodou as forças políticas que passaram a disputá-las pela via eleitoral e pela via das armas. Em ambos os casos, a solução do conflito e a reconstrução da autoridade Estatal 
deu-se majoritariamente por meio da reconstrução da estabilidade política, consequência da derrota de um dos lados do conflito.

Essa explicação, contudo, encontra fraquezas importantes quando aplicada à superação dos conflitos civis e à reconstrução estatal de Ruanda e Libéria. Apesar de ambos terem praticamente negligenciado a questão da nomocracia nos acordos de paz que foram negociados e firmados durantes suas guerras civis, ambos apresentaram melhorias significativas nos três indicadores da autoridade estatal. No caso liberiano, a agenda de negociações para o futuro do país foi bem mais equilibrada em relação à autoridade estatal e à efetividade da governança do que em Ruanda, que enfocou mais o segundo. No entanto, os resultados práticos desses acordos em ambos os países foram bastante diferentes, mesmo com a presença da ONU em ambos. Enquanto o primeiro conseguiu estabilizar-se e promover políticas que fortalecessem sua estabilidade, nomocracia e a efetividade de sua governança via meios democráticos, o segundo, exatos oito meses após a celebração do acordo de paz entre o governo e a FPR, sucumbiu novamente ao conflito e, pior, ao genocídio.

Os motivos para resultados tão distintos dos 27 acordos de paz celebrados nesses quatro países entre 1989 e 2003 podem ser encontrados no fato de que negociar e celebrar um acordo de paz não significa que as partes estejam prontas ou dispostas a cumpri-lo. Neste sentido, é preciso atentar ao fato de que a disposição para iniciar as negociações não é necessariamente a mesma para que elas tenham êxito ou sejam implementadas. Em Angola, por exemplo, as condições que permitiram as negociações deterioraram-se pouco depois da conclusão das negociações uma vez que a UNITA não estava mais disposta a cumprir os acordos (Ramsbotham, Woodhouse, \& Miall, 2011). O mesmo pode ser dito sobre o destino que tomou Ruanda oito meses após a celebração do acordo de paz de 04 de abril de 1993. Estes são dois casos extremos que ilustram como muitos países africanos continuaram a ter altas taxas de mortes violentas mesmo depois da celebração de acordos de paz que teoricamente terminariam as guerras. Neles, "a maioria das vítimas foi morta após a conclusão dos respectivos acordos de paz que encerravam as guerras civis" (Williams P. D., 2011).

O que gerou essas diferenças na (re)construção desses Estados tampouco parece ter sido o papel de quem encabeçou o processo. Dos quatro países, apenas a República do Congo não recebeu nenhum tipo de intervenção internacional durante ou após o conflito. 
Os outros três receberam operações voltadas a auxiliar a administração da transição da guerra para a paz após o estabelecimento de um cessar-fogo ou da assinatura de um acordo de paz. No entanto, tal intervenção internacional foi relevante para a reconstrução estatal apenas na Libéria, onde a Missão das Nações Unidas na Libéria (UNMIL) foi instaurada em 2003 e tem auxiliado o processo de paz e de consolidação das instituições daquele país. Em Angola, a reconstrução estatal não fazia parte do mandato de nenhuma das duas missões da ONU que foram implantadas no país e que já haviam sido concluídas em 2002, quando a guerra acabou ${ }^{171}$, e em Ruanda a Missão de Assistência das Nações Unidas para Ruanda (UNAMIR) falhou em garantir o sucesso do acordo de paz e teve seu contingente drasticamente reduzido durante os meses em que o genocídio aconteceu.

Neste sentido, é importante destacar que mais importante do que quem implementou as políticas que levaram à reconstrução do Estado, é quais foram as políticas implementadas. Entre estes quatro países, a Libéria é um caso particular quando se trata de quem, mas não é nada excepcional quando o assunto são as medidas tomadas tanto para recuperar a autoridade estatal quanto para retomar o desenvolvimento. Se por um lado, a Libéria foi um caso em que os atores responsáveis pela reconstrução foram eleitos em 2005 e contaram com a ajuda de uma missão da ONU, por outro o trajeto trilhado pelo país para a reconstrução apostou nos mesmos caminhos que os outros três países analisados nesta seção. A própria presidente liberiana Ellen Johnson Sirleaf admitiu em entrevista: "o único país que eu quis seguir foi Ruanda, embora fosse um ambiente bem diferente" (Mills, 2014, p. 272). Isso se dá ao fato de que Ruanda logrou reconstruir seu Estado e promover impressionante crescimento econômico nos vinte anos que se passaram após o fim da guerra civil e do genocídio.

De algum modo, os quatro países passaram por tentativas de acomodar as forças políticas antagônicas dentro do espectro político criando assim governos interinos e partilhando o poder. No entanto, em nenhum deles a partilha de poder gerou o fim definitivo do conflito e assim não lançou fundações sólidas para a reconstrução estatal. Um dos principais motivos para isso é que a partilha de poder não representou as potencialidades militares dos grupos beligerantes e consequentemente não alterou os cálculos de que ainda seria possível (e quiçá mais fácil) atingir os objetivos políticos pela

\footnotetext{
${ }^{171}$ A Primeira Missão de Verificação das Nações Unidas em Angola (UNAVEM I, 1988-1991) tinha em seu mandato o monitoramento da retirada das tropas cubanas do território angolano enquanto a UNAVEM II (1991-95) foi encarregada de supervisionar o cessar-fogo e as eleições de 1992.
} 
via das armas. No Congo, por exemplo, a oferta unilateral de Lissouba gerou reações distintas: Sassou Nguesso recusou os cinco ministérios que foram oferecidos ao PCT enquanto Kolelas aceitou a oferta para ocupar o cargo de primeiro-ministro que culminou na aliança entre os Cocoye e os Ninjas contra os Cobras. Como consequência, os distritos governados pelo MCDDI que até então eram considerados neutros passaram também a ser palco do conflito que agora não se concentrava mais apenas no sul do país (Bazenguissa-Ganga, 1999).

Também os casos de Ruanda e Libéria demonstram que a mediação e a partilha de poder não foram suficientes para parar o conflito e lançar as bases para a reconstrução do Estado. Quanto ao primeiro, apesar de o Acordo de Arusha de 1993 ter previsto inclusão abrangente das principais forças políticas do país e dado peso igual para a FPR e o governista MRNDD, as divisões dentro do bloco governista permitiram o avanço de alas extremistas que rejeitaram e boicotaram o acordo desde as fases iniciais de sua implementação. Para as alas governistas mais radicais, o acordo era desvantajoso uma vez que alterava a balança de poder entre os grupos políticos e beligerantes, o que gerou a determinação de boicotá-lo, pondo em prática um golpe de Estado e assassinatos em massa. Entre esses atores, o limite dos custos aceitáveis para apoiar uma intervenção ou algum arranjo negociado era muito baixo. Neste sentido, a partilha do poder em Ruanda teve um impacto desestabilizador no país e não conseguiu manter-se durante o processo de implementação (Suhrke \& Jones, 2000; Dallaire, 2003; Rothchild, 2005; Sisk, 2009). Já no segundo, a questão da partilha de poder foi bastante complicada desde que Amos Sawyer assumiu a presidência do Governo Interino de Unidade Nacional em 1990, após a queda de Samuel Doe. Até o fim da I Guerra Civil da Libéria em 1997, a realidade do governo transitório foi que ele era todo controlado por grupos armados cujos líderes dificilmente entravam em acordo, o que fazia com que a partilha de poder tivesse pouca valia para diminuir os incentivos ao conflito armado. O Acordo de Abuja ${ }^{172}$ e as emendas que lhe foram feitas nos últimos dois anos do conflito também não tiveram muito êxito para mudar a situação (Sawyer, 2004).

A partilha do poder foi uma política ineficaz uma vez que não foi capaz de convencer as partes beligerantes que poderiam atingir seus objetivos depondo as armas. Nesses quatro casos, o fim do conflito deveu-se mais a uma transformação em sua

172 Acordo de Abuja para complementar os Acordos de Cotonou e Akosombo tal como foi posteriormente esclarecido pelo Acordo de Accra, de 19 de agosto de 1995. 
estrutura do que a qualquer outra coisa, uma vez que ou a balança de poder pendeu definitivamente para um dos lados (Angola, República do Congo e Ruanda) ou então o equilíbrio fortaleceu-se de tal modo que já não era mais interessante para nenhuma das partes continuar lutando (Libéria). Nos primeiros casos, a vitória militar do MPLA, dos Cobras e da FPR determinou não apenas o fim do conflito, mas também quem encabeçaria a agenda de reconstrução do Estado e criaria condições para sua implementação. Na Libéria, a vitória do LURD e do Movimento para Democracia na Libéria (MODEL) garantiu a renúncia de Charles Taylor após a assinatura do Acordo de Paz Abrangente de Accra, mas criou um impasse militar entre os dois grupos (que juntos controlavam $80 \%$ do território do país) e o governo. Por este motivo, a presença da UNMIL foi importante para desempenhar o papel de fiel da balança e encabeçar o processo de reconstrução. Assim, a vitória militar de uma das partes nos três primeiros casos e as eleições de presidenciais de 2005 na Libéria contribuíram bastante para a reconstrução da autoridade estatal uma vez que já não havia mais dúvidas ou contestações sobre quem efetivamente governava tais países e, consequentemente, a quem suas forças armadas eram submissas e deviam obediência.

É exatamente neste ponto em que se insere a importância dos processos de DDR e de reconstrução das forças armadas desses quatro países. Durante o período de seus conflitos, várias tropas não-estatais foram organizadas e armadas e assim desafiaram os Estados onde se encontravam e seus respectivos governos e que precisavam ser desmobilizadas a qualquer custo. Isso foi reconhecido em boa parte dos acordos (que tiveram ou não sucesso) celebrados entre os grupos combatentes angolanos, congoleses e liberianos. No entanto, houve grande dificuldade em executar o programa nesses países devido principalmente à falta de confiança entre as partes. Pode-se afirmar, por exemplo, que faltou coragem a Pascal Lissouba em desarmar e desmobilizar as três milícias enquanto foi presidente da República do Congo. O alto nível de militarização da política e a ausência de um exército nacional leal à constituição do país constrangeram-no a agir uma vez que ao fazê-lo poderia catalisar tensões políticas que culminariam em violência. Contudo, foi exatamente essa omissão que permitiu o advento da guerra civil em 1997, quando foi deposto por Sassou Nguesso, que tomou o cuidado de inserir tal assunto nos acordos de paz a fim de não ser vítima de ato semelhante ao que cometeu contra seu antecessor. Entretanto, é possível afirmar que os esforços de DDR previstos pelos acordos 
de 1999 não representaram um plano nacional sobre tal tema (Muggah, 2004), o que só aconteceria a partir de 2003.

Em Ruanda, por outro lado, nenhum dos acordos de paz celebrados entre o governo ruandês e a FPR trataram desta questão. Nem mesmo o Acordo de Arusha - no qual se pretendia selar finalmente a paz no país - fez menção a tal fenômeno. Além da falta de confiança entre as partes beligerantes, a não participação no acordo de grupos radicais que inclusive compunham o partido situacionista MNRDD fizeram com que a FPR mantivesse-se em alerta e pouco disposta a desmobilizar-se. Também, após os eventos de abril de 1994 e visto que o conflito e os perpetradores de violência haviam se espalhado na sociedade de maneira rizomática, seria difícil executar qualquer programa de DDR porque - entre outros fatores - a distinção entre combatentes e não-combatentes ficou bastante tênue e difícil de ser estabelecida após os episódios. Foi por este motivo que o programa de DDR em Ruanda esteve intimamente ligado com as gacacas e a justiça de transição no país.

Os processos de desarmamento e desmobilização nesses quatro países foram tudo menos harmônicos e tiveram que superar importantes obstáculos para chegar a algum resultado que impedisse a reconstrução estatal e a volta do conflito. Em todos eles, a questão do financiamento foi um problema bastante importante. Em determinados momentos, as agências internacionais e os doadores deixavam de contribuir ou diminuíam substancialmente suas contribuições com o processo. No entanto, maior que o problema de obtenção e aplicação dos recursos à DDR foi a questão de quem iria pôr em prática tal processo. Tanto em Angola quanto na Libéria, a falta de confiança entre as partes beligerantes retardou não apenas a execução do programa, mas também, e como consequência, o fim dos conflitos. Dúvidas sobre o cumprimento e a cooperação com o projeto pela outra parte, além de questionamentos sobre qual ator seria o responsável pelo desarmamento e a desmobilização das partes beligerantes tornaram bastante difíceis a reconstrução da autoridade nesses dois países. No caso angolano, a falta de confiança entre as partes fez com que ambas mantivessem grupos clandestinos armados mesmo após a assinatura do Acordo de Bicesse em 1991. Na ocasião, não apenas o MPLA mantinha abertamente uma força de polícia paramilitar como também ex-combatentes de ambas as partes escapavam dos campos de desmobilização junto de suas armas. Este foi um dos fatores que permitiu à UNITA rejeitar o resultado das eleições de 1992 e voltar para a luta armada. Uma vez que ela manteve soldados e poder de fogo, seus líderes mantiveram a 
crença de que poderiam alcançar seu objetivo pela via armada. No final das contas, a desmobilização das tropas começou apenas após a assinatura dos acordos, em 1992.

Esta situação manteve-se mesmo após a assinatura do Acordo de Lusaca de 1994. Neste caso, não apenas UNITA e MPLA desmobilizaram menos combatentes do que havia sido acordado, como também se especula que muitos dos ex-combatentes desmobilizados mantiveram seus vínculos com a UNITA (Kingma, 2004) ${ }^{173}$. Por outro lado, as falhas no processo de DDR na Libéria remontaram ao programa estabelecido durante a I Guerra Civil Liberiana, um dos raros casos em que a intervenção com o intuito de reconstruir o Estado teve lugar enquanto o conflito estava acontecendo. Não é de se surpreender, portanto, que não houvesse confiança entre as partes beligerantes no tocante ao cumprimento dos vários acordos de paz que haviam sido celebrados desde 1989. Durante esta fase da falência de Estado da Libéria que atores como o Conselho de Paz Liberiano (CPL), a FPNL e o Movimento Unido de Libertação da Libéria para Democracia (MULLD) retomaram as hostilidades em muitos momentos, independentemente da presença do Grupo de Monitoramento do Cessar-Fogo dos Estados da Comunidade dos Estados da África Ocidental (ECOMOG) e da Missão de Observação das Nações Unidas na Libéria (UNOMIL) (Miller, 2013).

Apesar destas primeiras falhas no processo de DDR, os quatro países em questão passaram por programas desta natureza ou implementaram políticas que lhe eram convergentes quanto ao objetivo. Estas sim, após os conflitos terem sido encerrados obtiveram algum grau de sucesso. Neste sentido, é possível que esses programas tenham sido favorecidos pelo desempenho nas questões de desenvolvimento desses países. Como já afirmado, os quatro países deste capítulo apresentaram uma alta e positiva correlação entre autoridade e desenvolvimento. Este é um aspecto importante a se discutir pois uma vez que os combatentes tenham sido desarmados e desmobilizados, eles hão de encontrar alguma atividade remunerada que substitua os benefícios materiais (alimentação e às vezes renda) que provinham do conflito. Destarte, situações de desemprego endêmico e pobreza estrutural teriam um grande potencial para minar tal processo. No entanto, apesar das importantes melhorias que esses países vêm apresentando no que tange aos três

\footnotetext{
173136 mil combatentes haviam sido selecionados para serem desmobilizados dentro do processo estabelecido pelo Acordo de Bicesse. A falta de confiança entre as partes fez que muitos desses preferissem continuar atuando pelo MPLA ou pela UNITA. No espírito de Lusaca, dos 76 mil combatentes que deveriam ser desmobilizados, 50 mil passaram por tal processo, mas mantiveram seus relacionamentos com as partes beligerantes, o que manteve o poder militar delas (Lamb, 2013).
} 
indicadores do desenvolvimento, é possível afirmar que o sucesso do processo se deu mais ao fato de que estava em curso o processo de reconstrução das instituições estatais.

A questão sobre o que fazer com os ex-combatentes que já haviam sido desmobilizados e desmilitarizados em Angola e na Libéria permanecia aberta. Em casos como a Libéria, onde muitos dos ex-combatentes eram ainda crianças, o emprego não para o processo de reintegração. Não à toa, a UNMIL tomou o cuidado de manter separados adultos de crianças e homens de mulheres desde o início do processo de desmobilização. Enquanto os adultos eram encaminhados para campos de desmobilização (prática que também aconteceu em Angola), as crianças eram enviadas diretamente para um centro de cuidados administrado pela Fundo das Nações Unidas para a Infância (UNICEF). Planejava-se, portanto, a reintegração dos adultos à sociedade por meio de emprego e a das crianças ao devolvê-las para suas famílias. Além disso, tanto em Angola quanto na Libéria, os adultos que cumpriam o programa de DDR ganhavam uma ajuda de custo para iniciar a vida fora dos campos de desmobilização: na primeira, pagava-se em média US\$700,00 para cada combatente como assistência financeira para a reintegração enquanto na segunda, dava-se alimentos e US\$150,00 para o primeiro mês fora dos campos de desmobilização (Paes, 2005; Lamb, 2013).

No entanto, doze anos depois de terminada a guerra, Angola ainda estava com um programa de DDR incompleto e inconcluso: "muitos de seus ex-combatentes continuam a encarar incerteza, com desemprego endêmico em suas áreas rurais de origem apesar do programa de DDR de Luanda no pós-2002” (Mills, 2014, p. 366). Na Libéria, o programa de DDR foi a primeira atitude tomada pela UNMIL no sentido de construção da paz e reconstrução estatal após a assinatura do acordo de paz. A preocupação da missão da ONU e do novo governo liberiano era de que os combatentes pudessem conturbar a consolidação da paz no país. Contudo, três anos após o encerramento da fase de desarmamento e desmobilização, estimava-se que a taxa de desemprego no país atingisse alarmantes $80 \%$ da população economicamente ativa (Hanson, 2007).

Esses dados expõem apenas algumas dificuldades enfrentadas pelo processo de reintegração, mas não demonstram a contribuição que a conclusão dos processos de desarmamento e desmobilização e o próprio processo de reintegração deram à reconstrução da autoridade estatal nesses quatro países. O DDR neles não apenas reduziu o poder militar de forças concorrentes ao Estado e assim, garantiu a este o monopólio da 
violência, mas também reforçou as instituições governamentais, que eram encarregadas de conduzir o processo, e também as forças armadas e a polícia desses países. Isto é, o Estado e seus meios coercitivos também serviram para a reintegração dos excombatentes, uma vez que possuíam treinamento de combate e assim poderiam ser úteis se empregados pelo Estado.

Em Angola, a incorporação dos soldados da UNITA e do MPLA ao aparato coercitivo do Estado estava prevista desde o Acordo de Bicesse. Na ocasião, a Segunda Missão de Verificação das Nações Unidas em Angola (UNAVEM II) foi instalada pelo Conselho de Segurança da ONU para verificar o cumprimento do cessar-fogo e observar o processo eleitoral. ${ }^{174}$ Neste contexto era uma das responsabilidades da missão da ONU auxiliar a desmobilização dos combatentes, principalmente durante o processo eleitoral quando recebeu reclamações de partidos pequenos da contínua existência das Forças Armadas Populares de Libertação de Angola (FAPLA, vinculadas ao MPLA) e das Forças Armadas de Libertação de Angola (FALA, vinculadas à UNITA) e do consequente atraso na desmobilização de soldados e na criação das Forças Armadas Angolanas (FAA). Na ocasião, previa-se as FAA - quando criadas - teriam 50 mil homens à sua disposição. ${ }^{175}$ Contudo, a criação nominal das FAA só aconteceria a apenas dois dias das eleições de 1992. O motivo para tal atraso foi devido ao receio das partes de que haveria três, e não apenas um exército destacado para agir durante o pleito (Anstee, 1996; Porto, Alden, \& Parsons, 2007).

Mais tarde, sob o espírito do Acordo de Lusaca, uma série de instituições governamentais foram criadas para acabar com o caráter ad hoc do processo de DDR e dar mais sustentabilidade ao processo. Primeiro, o Gabinete Interministerial de Apoio aos Desmobilizados das Forças Armadas (GIAMDA) foi substituído pelo Instituto de Reintegração Sócio-Profissional dos ex-Militares (IRSEM), que foi responsável pela implementação de uma série de projetos de formação profissional, infraestrutura, reassentamento comunitário e microcrédito. Estes projetos, contudo, tiveram pouco impacto porque o próprio processo de DDR foi falho neste período. Além de visar a concluir a constituição das FAA, sob o Acordo de Lusaca também pretendia-se integrar

\footnotetext{
${ }^{174}$ S/RES/696 (1991) e S/RES/747 (1992).

175 Deste total, tanto o MPLA (governo) quanto a UNITA seriam responsáveis por conceder 20000 soldados cada. As FAA também teriam 6 mil homens na Força Aérea e 4 mil na Marinha (Porto, Alden, \& Parsons, 2007).
} 
5500 combatentes da UNITA na Polícia Nacional Angolana (PNA). Foi apenas a partir da morte de Jonas Savimbi em 2002 e o consequente fim da Guerra Civil Angolana que o processo de DDR e a incorporação de combatentes nas forças coercitivas do Estado angolano passaram a acontecer efetivamente. As importantes vitórias militares que o governo angolano impôs à UNITA nos anos anteriores fizeram com que então houvesse a necessidade principal de desmobilizar e desarmar a UNITA, que já era considerada apenas um grupo rebelde desde a criação do Governo de União e Reconciliação Nacional (GURN) em 1997. Talvez por isso, as forças armadas do governo tenham sido deixadas de fora desta última etapa de DDR. Nela, o IRSEM lançou o Programa Geral de Desmobilização e Reintegração (PGDR) que visava à desmobilização de cerca de 80 mil combatentes da UNITA e destes destacar 5000 para a PNA, desta vez sob a égide do Memorando de Entendimento de Luena, de 2002 (Messiant, 2004; Vines \& Oruitemeka, 2009).

Os resultados do programa de DDR em Angola parecem ter cumprido integralmente seu papel político e apenas parcialmente atingido seu objetivo social. Por um lado, Angola logrou eliminar as potenciais ameaças armadas vinculadas a grupos rivais. A condução da guerra e a administração do pós-guerra fez com que a UNITA depusesse as armas e se transformasse em partido político. A incorporação de soldados e ex-combatentes da guerra civil às FAA é um dos motivos pelos quais o país hoje tem o sexto maior poderio militar do continente segundo o Global Firepower Ranking (2016). Além disso, o relatório final do Programa de Desmobilização e Reintegração de Doadores Múltiplos $(\mathrm{PDRDM})^{176}$ sobre suas atividades em Angola mostrou importante evolução (e também importantes desafios) no tocante à reintegração social e econômica daqueles que não foram incorporados pelas FAA em 2008. Por um lado, 95\% dos desmobilizados tiveram acesso a terras para agricultura, $98 \%$ deles tinham estabelecido família e $93 \%$ sentiam-se totalmente reintegrados. Por outro lado, apenas $4 \%$ deles tinham emprego formal e $61 \%$ eram trabalhadores autônomos ou profissionais liberais ao passo que preocupantes $35 \%$ deles continuavam desempregados. Por fim, o próprio resultado final do projeto mostra que 93\% do público-alvo do Programa de Desmobilização e Reintegração de Angola

\footnotetext{
176 O PDRDM (Muilti-Donor Demobilization and Reintegration Program - MDRP, em inglês) é um programa de múltiplas agências internacionais em parceria com o BM que operou entre 2002 e 2008 na região dos Grandes Lagos e na África Central.
} 
(PDRA) foi desmobilizado enquanto apenas $69 \%$ foram efetivamente reintegrados à sociedade (MDRP, 2008; MDRP, 2012).

Assim como em Angola, o processo de DDR na República do Congo também visou mais ao restabelecimento da estabilidade política e da segurança do país e também passou por fases em que sua implementação foi dificultada devido ao retorno da violência. Primeiro, o processo de DDR foi praticamente inexistente após as eleições de 1992, que levaram Lissouba ao poder. Como já dito, Lissouba fracassou em desmobilizar e desarmar as três milícias que mediram forças durante a campanha eleitoral devido ao alto grau de militarização da política no país combinado com a ausência de um exército leal à constituição e aos ideais republicanos. Apesar de ter evitado que o país mergulhasse em um caos ainda maior ao não levar a cabo tal processo, Lissouba manteve uma fraqueza estatal que lhe custou o cargo.

Foi apenas após a segunda onda de violência no Congo (1997-99) que o processo de DDR entrou na agenda política do país de modo a aumentar a autoridade do Estado. O Acordo de Cessação de Hostilidades na República do Congo previa o desarmamento e a desmobilização das milícias e forças paramilitares bem como a reintegração dos combatentes que renunciassem às armas e ao uso da violência. Neste sentido, o acordo previa a volta da Força Pública ${ }^{177}$ nas cidades, portos, aeroportos etc., a desmilitarização dos partidos políticos, a reabilitação dos poderes públicos e costumeiros, a reabilitação e reintegração da Força Pública, do serviço público e dos estabelecimentos de ensino, a instauração de um Comitê de Acompanhamento do Acordo de Cessação de Hostilidades na República do Congo (CAACH) e o desarmamento dos atores paramilitares. Também o Acordo de Cessação de Hostilidades entre o Alto Comando da Força Pública e o Alto Comando da Forças de Autodefesa da Resistência, assinado pouco mais de um mês depois, foi nesse mesmo sentido e dava importante ênfase à inserção dos quadros combatentes da FADR na Força Pública como parte de sua reinserção na vida social.

Apesar das determinações dos dois acordos de paz de 1999, o governo de SassouNguesso demonstrou boa vontade com o processo de paz ao dissolver (formalmente) os Cobras, mas falhou (por falta de capacidade ou de vontade) em criar uma política una e sólida de DDR que pudesse ser aplicada em todo o território congolês. ${ }^{178}$ Isso, contudo,

\footnotetext{
177 No caso congolês, o termo "Força Pública" refere-se ao conjunto exército, gendarmaria e polícia. ${ }^{178}$ Dois anos depois e após um ataque surpresa dos Ninjas ao aeroporto de Brazzaville, Sassou Nguesso remobilizou os ex-Cobras que viviam na cidade e conseguiu impedir a escalação da crise que se inaugurava.
} 
foi compensado pelas ações de vários stakeholders que implementavam sozinhos suas políticas, o que deu um caráter ad hoc ao processo e não foi capaz de restaurar de maneira significativa a estabilidade política do país. Mesmo assim, as medidas tomadas entre os acordos de paz de 1999 até a celebração do acordo de 2003 (que pôs fim às hostilidades no departamento de Pool) eram marcadas pela forte preocupação em auxiliar a estabilidade e a segurança do país, deixando de lado as medidas de reintegração de combatentes à sociedade que dependessem de melhorias na economia nacional (Muggah, 2004; Themnér A. , 2011).

Entre os anos de 2000 e 2002, foi instaurado o CAACH que foi incumbido de desmobilizar mais de 20 mil combatentes e apreender as armas em circulação de todas as três milícias principais e outros grupos armados que participaram de alguma forma da guerra civil de 1997-99. Esta atitude estava prevista tanto no acordo de Pointe Noire (de 16 de novembro de 1999) quanto no acordo celebrado entre a Força Pública e a FADR, pouco mais de um mês depois. O objetivo desta medida, claro, era reconstruir o monopólio da violência por parte do Estado, agora controlado por Sassou Nguesso. Outra medida tomada nesse período foi um projeto do PNUD em parceria com Organização Internacional para Migrações (OIM) que, atendendo a um pedido do governo congolês, visava a desarmar e reintegrar os ex-combatentes por meio não apenas da apreensão de armas, mas também de vários projetos menores que lhes ofereceriam treinamento profissionalizante. Por fim, o BM garantiu à República do Congo uma linha de crédito de US\$5 milhões para a formação do Alto Comissariado para a Desmobilização e Reintegração dos Ex-Combatentes (ACDREC).

Estas duas medidas tinham como objetivo resolver não apenas o DDR relacionado ao conflito daquele país, mas também procurar solução para a quantidade de combatentes de outros conflitos da região que por algum motivo encontravam-se no território da República do Congo. Essas três políticas não chegaram a apresentar melhorias significativas. Por mais que tenham havido esforços para o desarmamento e para a reintegração, sobraram dúvidas sobre quais haviam sido os esforços para e os resultados do processo de desmobilização. Na verdade, nunca houve consenso nem mesmo sobre o número de combatentes e ex-combatentes que estiveram na República do Congo. Mesmo após o lançamento do Programa Nacional de Desarmamento, Desmobilização e Reintegração (PNDDR) em 2003, as estimativas de indivíduos elegíveis para serem beneficiados pelo programa variavam muito: para o PDRDM, apenas 8 mil pessoas eram 
elegíveis enquanto, nas estimativas do governo, o número subia para 41 mil (Muggah, 2004; World Bank, 2005).

Um dos motivos para a falha no processo de DDR desse período foi decorrente das diferentes interpretações sobre o significado e os objetivos dos programas a serem implementados. Ainda que a sigla seja clara e direta em seu significado (desmobilização, desarmamento e reintegração), há profundas diferenças e debates sobre como atingir tais objetivos e quando tais diferenças conceituais e teóricas se encontram no plano de atuação e aplicação, o resultado não pode ser animador. No caso da República do Congo - como já dito - dois programas de DDR foram encaminhados entre os anos 2000 e 2003 devido à falta de um programa nacional.

Por um lado, o PNUD e a OIM lançaram um programa de DDR logo após a celebração dos acordos de Pointe Noire e de Brazzaville, ou seja, no rescaldo dos episódios de violência entre as milícias e logo após ao estabelecimento do cessar-fogo. Talvez por isso, o projeto visava a promover o desarmamento e a reintegração como meio de reduzir a insegurança do país. Entendia assim que o conflito poderia voltar a qualquer momento se os ex-combatentes estivessem ainda armados e vagando desocupados pelas ruas. Por isso, as atividades de DDR que foram promovidas no quadro dessas duas organizações eram voltadas mais a impedi-los de desestabilizar o país novamente, com pouca preocupação sobre o desenvolvimento social e econômico do país. Talvez por isso, ex-combatentes que eram considerados inaptos ao conflito (mutilados, doentes etc.) foram simplesmente deixados de lado enquanto a assistência para reintegração estava reservada para aqueles que sim podiam representar alguma ameaça e foi desta maneira tratada como um incentivo para depor as armas - não como uma recompensa.

Por outro lado, a ACDREC e o BM iniciaram seu programa de DDR alguns meses depois e agora em um contexto de reconstrução social e econômica pós-conflito. Para estes, a DDR representava uma oportunidade para o desenvolvimento uma vez que considerava todos os ex-combatentes (aptos ou não ao conflito) como portadores de capital humano. Deste modo, as atividades de reintegração destinadas aos ex-combatentes também eram oferecidas de algum modo às suas famílias. Elas incluíam projetos de apoio psicossocial e de combate ao HIV bem como investiam em infraestrutura para o desenvolvimento social dos indivíduos participantes e seus familiares, tais como escolas e clínicas de saúde. A ACDREC e o BM entendiam que os projetos de reintegração 
podiam não só se aproveitar das habilidades dos indivíduos-alvo, mas também incrementá-las (Muggah, Maughan, \& Bugnion, 2003; Muggah, 2004).

O segundo motivo pelo qual o DDR falhou na República do Congo entre 2000 e 2003 está mais relacionado às condições que devem ser obedecidas antes da implementação do programa, não importa qual seja a abordagem tomada pelo órgão responsável. Por mais que as atividades de DDR tenham como objetivo a construção da paz e a devolução do monopólio do uso da força ao Estado, elas não podem em momento algum substituir as soluções políticas para uma crise que tenha levado o Estado à falência e à guerra civil e apesar de terem sucedido os acordos de Pointe Noire e Brazzaville, no caso da República do Congo, tais atividades foram confrontadas com uma situação política ainda bastante instável no departamento de Pool, que circunda o departamento onde fica a capital Brazzaville. Por isso, as atividades de DDR naquela região só se tornaram possíveis e o PDRDM foi instalado no país apenas após a celebração do "Acordo de Paz e de Cessação das Hostilidades no Departamento de Pool". Tal acordo não apenas pôs termo ao conflito naquele distrito, mas também estava consonante com as atividades de desarmamento e reintegração, tal como os de Angola. Especificamente sobre a reintegração social dos excombatentes, o acordo previa que o governo da República do Congo garantiria que a reinserção socioeconômica dos ex-combatentes seria feita por meio do seu recrutamento à Força Pública.

Foi apenas no fim de 2003 que o governo da República do Congo instituiu seu Programa Nacional de Desarmamento, Desmobilização e Reintegração (PNDDR), que seria financiado pelo Programa de Reintegração de Emergência da República do Congo (PRERC), sob a égide do PDRDM. Para garantir que os ex-combatentes não tornassem a representar uma ameaça à autoridade estatal, o PNDDR foi designado para ser desenvolvido pelo ACREC - que incluía representantes de todas as milícias, inclusive dos Ninjas do departamento de Pool - e contava com o apoio institucional da Comissão Nacional de Desarmamento, Desmobilização e Reinserção dos Ex-Combatentes (CONADER). A ideia do governo era de finalmente poder "consolidar a estabilidade no país, incluindo todos os elementos do processo de DDR e também determinados elementos relacionados à reforma e à racionalização do setor de segurança" (World Bank, 2005, p. 7). 
Pode-se dizer, contudo, que o PNDDR repetiu de alguma forma a falta de coordenação que os programas de DDR do PNUD-OIM e do BM-ACREC. A falta de coordenação e de consenso entre conceitos e políticas bem como de prioridades foi também uma característica da implementação do novo plano. Isto deveu-se principalmente ao fato de a PRERC não ter financiado todas as áreas do plano, uma consequência das perspectivas sobre o conflito por partes dos doadores do fundo. Assim, dos cinco pilares que sustentavam os planos do PNDDR, dois deles - intrinsicamente ligados ao fim do conflito e à restauração da autoridade estatal - não contaram com o financiamento internacional em questão pois não estavam dentro do escopo do PRERC. Apesar de que os pilares de ambos projetos sobrepusessem-se e coincidissem no tocante à desmobilização e reinserção, apoio à reintegração de grupos especiais tais como crianças-soldado e excombatentes com deficiência física permanente adquirida durante o conflito e prevenção e redução de conflitos, o PRERC completava seu escopo com a reintegração socioeconômica dos ex-combatentes e com o que chamava de "desenvolvimento institucional e apoio a programas de implementação" ${ }^{179}$. Desta forma, os esforços de desarmamento e de reforma do setor de segurança da República do Congo foram deixados sob responsabilidade exclusiva do governo do país e do ACDREC.

O processo de DDR, contudo, continuou enfrentando desafios importantes até 2005 quando ainda Cocoye e Ninjas tentavam retomar o poder pela via das armas, mostrando que os acordos de paz de 1999 e 2003 e todo o processo de DDR havia tido até então efeito limitado na reconstrução da autoridade estatal. Por isso, é possível afirmar que os avanços verificados nos processos de DDR de até então foram mais devido à dinâmica do conflito e da acomodação de suas forças do que a implementação de suas políticas de fato. Apesar de os Ninjas terem continuado a luta armada, os Cocoye de Lissouba já não eram mais convocados a resistir com armas ao regime de Nguesso (o que possibilitou a celebração dos acordos de paz de Pointe Noire e Brazzaville), mas ainda encabeçavam o processo de boicote político ao regime. Foi apenas em outubro de 2005 que Lissouba passou a aproximar seu partido, o UPADS, ao regime e foi a partir de tal gesto que se pode dizer que a política na República do Congo começou a desarmar-se e possibilitar assim o processo de DDR e de reconstrução da autoridade estatal.

\footnotetext{
${ }^{179}$ Este último tratava da criação de mecanismos institucionais dentro do governo congolês que coordenaria os programas de DDR em nível nacional, provincial e municipal. Ele não foi designado para aprimorar a governança das instituições congolesas já existentes.
} 
De todo modo, até a conclusão do projeto de DDR do PDRDM em fevereiro de 2009, 11 mil combatentes foram desmobilizados e receberam o apoio para reinserção social. Além disso, quase 19 mil ex-combatentes que se desmobilizaram voluntariamente receberam apoio de reintegração socioeconômica do programa. Apesar de esses números terem praticamente atingido a meta do PDRDM, o sucesso do processo de DDR do país é questionável uma vez que a desmobilização e reinserção dos combatentes de Pool e da Força Pública - que estava sob a responsabilidade do ACREC - não foi executado concomitantemente ao projeto do PDRDM. Além disso, o próprio processo de desarmamento dos combatentes de Pool começou oficialmente em fevereiro de 2009, ou seja, quando o projeto da PDRDM se encerrou (MDRP, 2012). Talvez por isso, entre os quatro países analisados neste capítulo, a República do Congo seja a que teve o pior desempenho de autoridade estatal entre 1996 e 2011.

No outro extremo do crescimento nos níveis de autoridade no período encontra-se Ruanda que - como já foi dito - teve o melhor desempenho não apenas no índice agregado de autoridade como nos três itens que o compõem. Por mais que tenha tido, no geral, desempenho muito melhor que o de Angola e da República do Congo, o país se assemelha a eles no fato de também nele a guerra civil ter sido concluída com uma clara vitória de uma das partes. Em 1994, a FPR concluiu seus planos de invadir o país e derrubar o governo de Quigali. Face a impotência e incompetência da UNAMIR, os acordos de paz foram ignorados e violados por ambas as partes do conflito. Tendo em vista que a FPR comandou o processo de reconstrução do Estado, o fato de os acordos não terem previsto o processo não deveria significar muita coisa. Contudo, ela procurou reerguer as instituições estatais seguindo o chamado "espírito de Arusha", isto é, os princípios dos acordos de paz de 1993 (veja tabela 12). ${ }^{180}$ Deste modo, qual foi a base para que o novo governo o fizesse?

Uma das grandes dificuldades de implementação do processo de DDR em Ruanda foi a existência do fenômeno de spill over do conflito na República Democrática do Congo, que tem como marco a derrocada do então presidente Mobutu Sese Seko em 1997.

\footnotetext{
${ }^{180} \mathrm{O}$ que mais se aproxima do assunto DDR nos acordos de paz celebrados durante a guerra civil de Ruanda (1991-94) foi a integração das forças armadas das partes beligerantes às Forças Armadas do país. O artigo 74 Protocolo do Acordo entre o Governo da República Ruandesa e a Frente Patriótica Ruandesa sobre a Integração das Forças Armadas dos Dois Partidos previa que a FPR seria integrada em um novo exército nacional de aproximadamente 19 mil soldados e na nova polícia nacional que teria 6000 pessoas. As posições de comando seriam partilhadas igualmente.
} 
O conflito congolês no país que durou de 1996 a 2003 e também a insurgência hutu no noroeste de Ruanda entre 1997 e 1998 e em 2001 complicaram o processo uma vez que dificultaram a identificação dos combatentes de cada conflito. Assim, o processo que deveria ser voltado inicialmente apenas para os combatentes da guerra civil ruandesa teve de ser expandido também para os soldados desses outros conflitos. Mesmo assim, Ruanda não anistiou os combatentes de sua guerra civil que tiveram envolvimento com o genocídio. Enquanto nos outros três países analisados neste capítulo, a anistia foi précondição para o sucesso do processo de DDR, em Ruanda a atuação dos combatentes enquanto tal foi anistiada, mas o envolvimento com o genocídio não.

O primeiro estágio do processo foi levado a cabo entre 1997 e 2001 e tinha como objetivo principal a desmobilização dos combatentes do Exército Patriota Ruandês $(\mathrm{EPRu})$, isto é, do antigo exército ruandês. Para tanto, o novo governo criou a Comissão Ruandesa de Desmobilização e Reintegração (CRDR) que foi encarregada de desmobilizar, desarmar e reintegrar quase 19 mil soldados do antigo regime. Especialmente no tocante à reintegração, a comissão possuía um orçamento de US\$183 milhões que seria destinado a projetos de microcrédito e de orientação vocacional. Apesar de ter reintegrado pouco menos do total previsot, a CRDR encontrou bastantes dificuldades. Primeiro, os doadores internacionais tinham ressalvas quanto a financiar qualquer projeto de Quigali, temendo que o dinheiro fosse desviado para fortalecer o desempenho militar de Ruanda, cada vez mais envolvida na guerra civil da República Democrática do Congo (Zaire), o que obrigou o governo a financiar quase metade do projeto. Segundo, o projeto de microcrédito foi encerrado em 2000 devido aos maus resultados, causada pela falta de expertise dos beneficiários para tocar seus negócios e pelas dificuldades da economia do país. Mesmo assim, o projeto foi considerado de sucesso pelo PNUD uma vez que os soldados desmobilizados foram reintegrados à sociedade e que, mesmo face às dificuldades econômicas, não resultaram no aumento na criminalidade (Kingma, 2011).

Foi apenas no segundo estágio do processo (2002-2008) que os doadores internacionais tiveram um pouco mais de espaço no processo. Apesar de não terem diminuído as incertezas sobre o envolvimento ruandês no conflito da República Democrática do Congo, os bons resultados do estágio anterior fizeram com que doadores internacionais se aproximassem por meio do PDRDM, o mesmo que auxiliou Angola e República do Congo. Com orçamento mais modesto (cerca de $70 \%$ menor), o Programa 
de Desmobilização e Reintegração em Ruanda estava sob o controle da CRDR e teve mandato prorrogado em 2005 para mais três anos, uma vez que só havia atingido a aproximadamente $30 \%$ de seu objetivo (MDRP, 2007). ${ }^{181}$ Nesta fase, as pessoas a serem desmobilizadas eram enviadas para locais onde receberiam cursos de história de Ruanda, educação cívica entre outros assuntos e, quando concluído, recebiam um apoio imediato de US\$100,00 mais uma verba de apoio à reintegração que podia variar de US\$150,00 a US\$2000,00, de acordo com sua patente e lado do conflito. Ao final do segundo estágio, a situação que se apresentava era de que apesar de a reintegração econômica não ter sido capaz de superar a pobreza dos ex-combatentes, eles não se encontravam em situação pior do que da maioria da população. Além disso, a grande maioria dos desmobilizados afirmou não ter sentido nenhuma forma de discriminação nas comunidades onde foram reintegrados e que muitos ocupavam nelas cargos de autoridade ao longo do processo (Mehreteab, 2005).

Os processos de DDR que foram abordados até agora enfrentaram uma série de dificuldades advindas, principalmente, do andamento do processo de paz, sem o qual a construção dos Estados fica bastante dificultada. Como já foi visto, tanto em Angola quanto na República do Congo, a falta de confiança entre as partes praticamente impossibilitou o cumprimento dos acordos de paz que previam o estabelecimento de tal processo. Tal como eles, o processo de DDR em Ruanda também foi levado a cabo pela parte vencedora da guerra, que rechaçou uma nova intervenção internacional e ditou a agenda de paz e do processo em questão. Como se viu até este ponto, esses processos de DDR tiveram algumas semelhanças importantes sobre quem e como os conduziu (ou seja, os meios do processo) e também sobre como os processos representaram uma queda na ameaça à autoridade estatal e foram utilizados para a sua reconstrução (ou seja, os fins do processo).

O último processo de DDR a ser apresentado neste capítulo apresenta diferenças importantes em seus meios, mas aponta para semelhanças em seus fins com os anteriores. Na Libéria, os processos de paz e de reconstrução estatal que sucederam suas duas guerras civis (1989-97 e 1999-2003) tiveram a participação protagonista de atores internacionais, mas tentaram implementar políticas análogas às dos outros três países deste capítulo para

\footnotetext{
${ }^{181}$ O programa teve um desempenho anual abaixo do esperado em 2005, quando conseguiu desmobilizar e reintegrar apenas $45 \%$ do público-alvo daquele ano. Em 2007, contudo, o programa já estava bem mais avançado e beirando o $80 \%$ de sucesso (RDRC, 2006; MDRP, 2007).
} 
atingir seus objetivos. Ao contrário dos outros casos em que é possível identificar uma linha de continuidade nos processos de DDR e reconstrução estatal, tais dinâmicas na Libéria são claramente divididas em duas fases que apresentam diferenças significativas não apenas nos seus resultados: se o primeiro processo de construção de Estado na Libéria (1993-97) foi feito com base em uma percepção bastante equivocada entre sua estratégia e o grau de falência estatal, a segunda intervenção no país (2003-presente) apresentou mudanças significativas e pode ser considerado um sucesso provável de reconstrução estatal (Miller, 2013). ${ }^{182}$

A Primeira Guerra Civil Liberiana, inaugurada em 1989, instaurou o caos no país de tal forma que o país beirou a anarquia. Não é exagero dizer que o início da guerra civil acabou com o pouco que restava da percepção de autoridade estatal naquele país. Como já foi dito, a paz no país havia sido garantida por Samuel Doe e pelos demais presidentes que o precederam devido ao que foi referido como "inibidores de conflitos", dentre os quais a repressão política e uma vasta rede patrimonialista que garantia o apoio ao governo e, consequentemente, a governança. No entanto, conforme Taylor foi atacando o país e suas instituições, o aparato repressivo do Estado enfraquecia-se paulatinamente e à medida que os gastos para o manter cresciam, diminuía o tamanho do botim para alimentar a rede patrimonialista que dava suporte ao governo.

Após o golpe de Estado promovido por Charles Taylor e o consequente assassinato de Samuel Doe em setembro de 1990, a Libéria entrou em um período complicado que duraria pelo menos até 1997 . Nesse período, o país foi governado por um presidente interino até 1994 e depois por um Conselho de Estado, previsto no Acordo de Cotonou (de 25 de julho de 1993) e que era composto por representantes das partes beligerantes. O governo durante esse tempo não era nada mais do que mera formalidade e extremamente fraco uma vez que os atores que não concordavam com os vários acordos de paz julgavam que lhes era mais benéfico retomar a luta armada. Durante esses primeiros anos da guerra civil, as instituições estatais liberianas simplesmente deixaram

\footnotetext{
${ }^{182}$ Apesar de Miller ter feito tal avalição em 2013, pode-se dizer que seu julgamento ainda se mantém três anos depois. De acordo com seus critérios, o país tem melhorado suas condições de governança e continua a apresentar crescimento econômico e não tem apresentado genocídios, limpezas étnicas e crimes de guerra. Para estes, não se pode afirmar o sucesso total uma vez que sua análise compreende o período da intervenção e um decênio após sua retirada. Quanto às questões de estabilidade política (ausência de violência política, golpes de Estado e rupturas de regime), não se pode afirmar ainda o sucesso quanto à estabilidade política uma vez que a intervenção ainda está em andamento e o critério de Miller considera para estes apenas o decênio após sua retirada.
} 
de operar. Não havia mais forças policiais capazes de promover a ordem e proteger os cidadãos e o sistema judicial do país havia deixado de existir (Miller, 2013). Foi neste contexto de ruína e implosão das instituições estatais que a ECOMOG fora criada em agosto de 1990, com um mandato ambíguo que lhe dava características ora de peacekeeping, ora de peace enforcement. Em seu mandato, contudo, não constava qualquer atividade de DDR, elemento fundamental da consolidação de processos de paz e de reconstrução da autoridade estatal.

Suas primeiras tentativas neste sentido surgiram entre junho e outubro de 1991, após uma série de negociações em Iamussucro, na Costa do Marfim. Nelas, as partes beligerantes planejaram criar condições políticas e militares para cessar-fogo, aquartelamento e desarmamento das forças beligerantes, criação de um novo governo interino e sobre medidas para a organização de eleições. Apesar de o cessar-fogo ter tido uma importante duração, não se pode dizer que essas rodadas de negociação tenham tido sucesso. Enquanto a FPNL e a ECOMOG respeitavam-no, o MULLD continuou a expandir-se e motivou a recusa de Taylor em desarmar sua FPNL. Além disso, Taylor utilizou este cessar-fogo como tempo para restabelecer suas forças e lançar uma ofensiva contra a ECOMOG em outubro de 1992, impondo-lhe um sítio de dois meses na capital Monrovia. Nas palavras do General Ishaya Bakut, um dos comandantes da ECOMOG, “Taylor não foi sincero sobre o desarmamento nem estava disposto a deixar qualquer coisa entre ele e a casa do Executivo". (Howe, 1996, p. 158). Para seu azar, a ECOMOG conseguiu reorganizar-se e lançar uma contraofensiva poderosa que o forçou a recuar de muitas das áreas que havia conquistado. Enfraquecido, Taylor foi forçado à mesa de negociações de novo, desta vez para a assinatura do Acordo de Cotonou que traria mais uma vez a questão do governo interino e da DDR.

O momento político na Libéria que seguiu a assinatura do Acordo de Cotonou deveuse mais pela intervenção internacional que estava se organizando do que pelo prospecto de paz e fim do conflito. Seguindo uma resolução do Conselho de Segurança da ONU, o processo de paz da Libéria ganhou um reforço a mais. ${ }^{183}$ Agora, além da ECOMOG, também a UNOMIL somaria esforços para pôr termo ao conflito. Especificamente, a missão da ONU tinha em seu mandato a responsabilidade por monitorar o cessar-fogo e o cumprimento do acordo de paz, observar e verificar o processo eleitoral, treinar as

${ }^{183} \mathrm{~S} / \mathrm{RES} / 866$ (1993) 
forças da ECOMOG ${ }^{184}$, e promover a desmobilização e o desarmamento imparcial e também criar um plano financeiro para que a reintegração dos ex-combatentes fosse viável. No entanto, além de o mandato da UNOMIL ter sido inapropriado para as circunstâncias e ter contado com contingente civil e militar extremamente baixo, também as partes beligerantes resistiram e recusaram-se a desarmar, o que deu continuidade ao conflito. Ainda que em 1997 a intervenção da ONU tenha conseguido criar condições para a realização de eleições gerais no país, ela não foi capaz de impedir que o conflito retornasse dois anos depois. Estava mais do que claro que tanto o ECOMOG quanto a UNOMIL falharam em fortalecer a segurança pública e forçar o desarmamento dos combatentes (Miller, 2013).

A paz celebrada em 2003, após a chamada Segunda Guerra Civil Liberiana demonstrou que importantes avanços haviam sido feitos com relação ao processo iniciado dez anos antes. Desta vez, além do cessar-fogo, da criação de um governo interino e da intenção em desarmar os combatentes, o acordo de paz foi complementado também com a desmobilização, reabilitação e reintegração dos ex-combatentes (uma versão mais abrangente do processo de DDR) e também incluiu a necessidade de uma reforma no setor de segurança do país, uma vez que tanto as forças armadas quanto a política nacional foram parte da guerra civil e - apesar de cumprirem dever constitucional de defesa do regime - representavam na verdade os interesses da FPNL, que havia ascendido ao poder em 1997. ${ }^{185}$

No entanto, diferentemente dos casos analisados anteriormente neste capítulo, esse novo caso liberiano tratou o DDR e a reforma do setor de segurança separadamente. Se nos outros casos entendeu-se que a incorporação de ex-combatentes ao aparato coercitivo do Estado era uma forma tanto de reintegração social quanto de despolitizá-lo, o Acordo de Paz de 18 de agosto de 2003 entendeu que as Forças Armadas da Libéria também deveriam desengajar do conflito e serem aquarteladas a fim de passar pelo processo de DDR para que pudessem posteriormente ser reestruturadas. No texto do acordo, há uma

\footnotetext{
${ }^{184}$ Muitas críticas foram feitas no que diz respeito ao preparo militar e técnico dos oficiais e soldados da ECOMOG. Essas críticas geralmente tratam do financiamento insuficiente no treinamento das tropas, de sua falta de coordenação (alguns alegam que as tropas cumpriam objetivos estratégicos nacionais, mesmo sob a égide da ECOMOG), as dificuldades linguísticas, sociais e étnicas, etc. (Howe, 1996; Tuck, 2000; Adebajo, 2002; Miller, 2013).

${ }^{185}$ Apesar de Charles Taylor ter sido eleito para a presidência da Libéria em 1997, admite-se que seus eleitores apenas votaram nele com medo de retaliações caso não o fizessem.
} 
única menção de que seus novos membros "poderão ser retirados dos quadros do GdL, do LURD e do MODEL", mas não houve o compromisso de fazê-lo tal como em Angola e na República do Congo. ${ }^{186}$ Ao positivar este entendimento e não transformá-lo em uma obrigação, as partes envolvidas na reconstrução do Estado liberiano garantiram que o processo de DDR no país teria caráter civil.

Além disso, esse processo foi colocado como tarefa central da reconstrução estatal liberiana. Não à toa, o acordo de paz que entendia que a responsabilidade por conduzir tal processo (principalmente a questão do desarmamento) caberia à UNMIL, via Unidade de Implementação Conjunta (UIC) e em conjunto com organizações humanitárias, UNICEF, PNUD e até com o Conselho Norueguês para Refugiados, e deu-lhe papel central na condução de todo o processo em conjunto com a Comissão Nacional de Desarmamento, Desmobilização, Reabilitação e Reintegração (CNDDRR). Tamanha foi a importância dedicada ao assunto que a comissão foi constituída "por representantes de agências relevantes do GNTL, o GdL, LURD, MODEL, ECOWAS, as Nações Unidas, a União Africana e o GCIL" e até determinou-se que ela teria um caráter interdisciplinar. ${ }^{187}$ Esta centralidade e importância dada pelas partes ao DDR foi reconhecida também por acadêmicos que entenderam que tal processo era indispensável para que a missão tivesse sucesso e que o DDR era crucial para a transição da guerra para a paz (Paes, 2005; Jennings, 2007). Além disso, até mesmo o então Secretário Geral da ONU chegou a afirmar que qualquer falha no processo de DDR "comprometeria todo o processo de paz e desestabilizaria a Libéria e toda a sub-região". ${ }^{188}$

Apesar de toda essa importância e atenção dedicada ao processo, ele não foi imune a dificuldades nem tampouco foi harmônico. $\mathrm{Na}$ verdade, três problemas principais (dos quais dois eram interligados) assolaram-no. Primeiro, a enorme falta de dados sobre a quantidade e identidade dos combatentes complicou a tarefa da CNDDRR e da UIC, que precisavam então confiar nas listas providas pelos grupos beligerantes. Inicialmente, apenas o GdL e o MODEL entregaram tais listas (cada uma contendo cerca de 12 mil nomes). Foi baseado nesses números e apostando que os dados da LURD não deviam ser

\footnotetext{
${ }^{186}$ Artigo VII do Acordo de Paz entre o Governo da Libéria, os Liberianos Unidos pela Reconciliação e Democracia (LURD), o Movimento para Democracia na Libéria (MODEL) e os Partidos Políticos, assinado em 18 de agosto de 2003. Ênfase adicionada.

${ }^{187}$ Artigo VII do Acordo de Paz entre o Governo da Libéria, os Liberianos Unidos pela Reconciliação e Democracia (LURD), o Movimento para Democracia na Libéria (MODEL) e os Partidos Políticos, assinado em 18 de agosto de 2003.

${ }^{188}$ S/2003/875, p. 13.
} 
muito diferentes que a UNMIL estimou que o total de combatentes que passariam pelo processo (incluindo de outras facções armadas menores que tomaram parte no conflito) seria de aproximadamente 38 mil pessoas, que seriam divididas para atendimento em três fases distintas. No final das contas, a imprecisão sobre os números pré-DDRR era tão grande que um relatório da CNDDRR e da UIC somou 102.193 pessoas atendidas (Paes, 2005; Munive \& Jakobsen, 2012).

O segundo problema pelo qual o processo de DDR passou foi decorrente deste primeiro. Não apenas era tensa a relação entre as facções que tomaram parte na guerra e a liderança da ONU no processo de paz como também seus líderes tinham consciência de sua posição privilegiada perante a ONU uma vez que eram eles que possuíam as informações necessárias sobre a quantidade e a identidade dos combatentes. A grande questão, contudo, foi que eles também estavam em excelente situação perante todos aqueles que gostariam de ser beneficiados pelo processo de DDRR, combatentes ou não. Desta forma, o fato de que as informações que eles dariam à UIC seriam aquelas sobre as quais o processo de DDRR se basearia (mesmo não sendo confiáveis), eles tinham o poder de "fazer e desfazer" os combatentes. Isto é, poderiam incluir ou excluir alguém da lista por uma série de motivos. No final das contas, esse poder "permitiu aos comandantes e generais de todas as facções a mobilizar extensivamente civis no processo de DDR em troca de lucro econômico".

Este processo foi possível e gerou muito interesse uma vez que muitos adolescentes e jovens solicitavam para serem incluídos na lista e eram recrutados com a condição de que aceitasse dividir os US\$300,00 que ganhariam ao entrar no programa (Munive \& Jakobsen, 2012, p. 368). Isto acabou gerando uma relação de clientelismo numa economia pós-conflito que era dominada pela ONU, mas também a comercialização do desarmamento: "muitas pessoas confirmaram que armas e munições eram obtidas por civis em troca de dinheiro para permitir matrícula como um ex-combatente" (Paes, 2005, p. 257). No final, essa relação de clientelismo e a comercialização do DDR acabou não rompendo os laços que ainda ligavam os ex-combatentes e seus comandantes, o que pode eventualmente traduzir-se em ameaça à paz e remobilização.

O terceiro problema que o processo de DDR enfrentou reside justamente na dificuldade de reintegração socioeconômica em uma economia frágil e sem muitas oportunidades de emprego. Até julho de 2009, quando o programa de reintegração foi 
oficialmente encerrado, cerca de 98 mil pessoas haviam sido beneficiadas pelos projetos financiados pelo PNUD e pela União Europeia (UE), Agência dos Estados Unidos para o Desenvolvimento Internacional (USAID) e UNICEF. No entanto, apesar do entendimento de agências internacionais e doadores de que a agricultura seria a melhor via de reintegração, devido às limitadas ofertas de emprego formal, a maioria dos beneficiários optou por programas de educação formal como atividade de reintegração, mesmo sabendo das dificuldades de conseguir um trabalho após a conclusão do processo. Um dos prováveis motivos para isso foi o curto tempo de aquartelamento e orientação vocacional aos beneficiários. Pode-se afirmar que as vantagens expostas por outras opções além da educação formal não lhes tenham sido convincentes, mesmo quando contrastadas com as dificuldades laborais que seriam encontradas nas cidades (Munive \& Jakobsen, 2012).

Mesmo com esses problemas, o processo de DDR levado a cabo na Libéria após o início da intervenção da ONU é considerado um sucesso. Não se esperava um nível tão alto de adesão e conformidade com o processo. Os três principais atores da guerra civil (GdL, LURD e MODEL) foram efetivamente desarmados e também pode-se afirmar que o programa "possibilitou uma vida muito melhor para aqueles ex-combatentes que completaram o programa de formação profissional quando comparados com aqueles antigos soldados que preferiram não se matricular e reintegrar-se sozinhos" (Pugel, 2006, p. 5).

Faltava ainda, contudo, a reestruturação e a reforma do setor de segurança e das forças armadas da Libéria tal como estava previsto no acordo de paz. Foi neste processo então que se demonstrou mais uma vez que a intervenção privilegiou a reconstrução da autoridade estatal em detrimento do desenvolvimento econômico e social. O entendimento da UNMIL e do governo interino era de que ações imediatas eram necessárias para criar benefícios imediatos da estabilidade. Foi neste sentido que a intervenção internacional se organizou. Em um comparativo com o momento que gerou uma intervenção dez anos antes, a situação da Libéria em termos de segurança estava melhor em 2003 apesar de sua população estar mais pobre e sua renda per capita ter caído mais de $30 \%$ nesse período. A preferência por incrementar a estabilidade e a segurança do país então deveu-se ao fato de que a segurança liderada por militares poderia criar as condições para o crescimento econômico (Miller, 2013; Mills, 2014). 
Os processos de reestruturação e de reforma das forças armadas e da polícia liberiana tinha como principal objetivo despolitizá-la, a fim de garantir que elas não voltassem a ser usurpadas como havia acontecido quando Taylor foi presidente. Apesar de a UNMIL e a Polícia das Nações Unidas (UNPOL) estarem presentes no país garantindo a estabilidade e a segurança do país e de seus cidadãos, era necessário começar a transição de seus serviços para as forças locais o mais rápido possível. Somente assim, e em atuação de longo prazo, seria possível também reconstruir a confiança da população em tais instituições e foi por este motivo que a UNMIL se apressou em começar a reforma dos serviços policiais. Além disso, a proximidade da campanha para as eleições presidenciais exigia que a UNPOL tivesse apoio de outras forças locais, mas também representava um grande desafio para a nova polícia liberiana. Por isso mesmo que a intervenção internacional tratou de garantir a conclusão do treinamento e a graduação da Primeira Turma da polícia liberiana no fim de maio de 2005, menos de três meses antes do início da campanha e quase seis meses antes da posse da presidente eleita Ellen Jonhson-Sirleaf.

Em consonância com a necessidade de mostrar não apenas que a estabilidade havia voltado ao país, mas também de trazer benefícios imediatos dela, as forças da intervenção internacional e a nova polícia liberiana acabaram sendo bem avaliadas pela população do país, mesmo que ainda se reconhecessem vários problemas. Três anos após a instauração da missão, $91 \%$ da população acreditava que a situação da segurança havia melhorado consideravelmente. Entretanto, as ainda altas taxas de criminalidade e a falta de um policiamento efetivo representavam as maiores preocupações da população no tocante à segurança, o que refletia a relativa baixa confiança da população na polícia liberiana (Krasno, 2006; Baker, 2010). ${ }^{189}$

Tais dados levaram a UNMIL a acelerar o treinamento da polícia e também a tomar outras medidas que ajudariam bastante a segurança dos liberianos. Tendo em vista que boa parte dos crimes ainda aconteciam à noite, a UNMIL deu prioridade para o lançamento do sistema de iluminação pública nas cidades em 2008 e, pouco depois, anunciou o início das operações noturnas da polícia. Além disso, como a questão da violência sexual e dos estupros estava atingindo números preocupantes, principalmente com muitas acusações a soldados da missão, buscou-se formar uma polícia

${ }^{189} 58 \%$ da população afirmava ter alguma confiança na eficiência da polícia e $13 \%$, não ter nenhuma confiança (Krasno, 2006). 
exclusivamente feminina - que começou a operar apenas em 2009. ${ }^{190}$ No geral, a segurança na Libéria tem sido garantida por um exército relativamente eficiente responsável pela defesa do território do país e por uma polícia que, treinada pela UNPOL, constituía uma força incoerente, de baixa qualidade e corrupta. No geral, a reforma e a reestruturação do setor de segurança da Libéria foi bem-sucedido no tocante à despolitização, mas ainda levanta bastantes dúvidas sobre sua eficiência. Segundo uma linha de pensamento, os liberianos teriam ficado muito dependentes da ONU e o impacto psicológico de uma retirada da missão (ainda que de forma gradual) pode gerar uma sensação de vácuo de segurança que poderá arruinar os avanços feitos e ameaçar novamente as instituições do país. Assim, ainda há dúvidas sobre a capacidade dessas novas instituições liberianas em garantir a ordem e a segurança quando a UNMIL encerrar seu mandato (Mills, 2014). Essa dúvida sobre o futuro, contudo, não parece ser uma realidade nos outros países deste capítulo, que dependeram muito mais (ou exclusivamente) de si mesmos para reconstruir-se.

Apesar das diferenças existentes entre os quatro países, as semelhanças que eles guardam entre si são suficientes para indicar a existência de uma predileção em promover políticas para reconstruir a autoridade estatal em um contexto pós-conflito em detrimento à promoção do desenvolvimento socioeconômico. Ainda que autoridade e desenvolvimento tenham tido correlação alta e positiva no período analisado (durante a guerra e pós-guerra), as falhas nas medidas que trataram de relacioná-los demonstram que também nestes países autoridade e desenvolvimento respondem a causalidades separadas (como Angola e República do Congo) ou que o desenvolvimento é promovido pela autoridade estatal e não o contrário (como demonstraram Libéria e Ruanda). A reintegração de ex-combatentes por exemplo não resultou em maiores índices de emprego ou de poder aquisitivo, mas sua desmobilização e desmilitarização removeu a ameaça e a existência de forças paralelas que poderiam desafiar o Estado. Além disso, a própria reintegração dos ex-combatentes também foi feita de modo a reforçar o aparato coercitivo dos Estados.

Estes fatos apontam na direção da hipótese deste trabalho de que as guerras civis e o colapso estatal na África Subsaariana é mais uma questão de fraca autoridade estatal do que de subdesenvolvimento. Como foi demonstrado, o início dos conflitos deu-se em

${ }^{190} 22 \%$ dos entrevistados reclamaram que soldados da UNMIL haviam estuprado mulheres e meninas e estavam encorajando a prostituição de jovens mulheres (Krasno, 2006). 
momentos em que não apenas questionou-se os governos desses países, mas principalmente desafiou-se as instituições estatais existentes. Deste modo, a única saída para o conflito seria justamente agir no eixo em que transitaram os acontecimentos. Se o problema foi com a baixa autoridade estatal, a resposta racional para reconstruir o Estado e evitar a repetição da violência só poderia ser restabelecendo-a. Até o momento, Angola, República do Congo, Libéria e Ruanda parecem tê-lo feito de modo satisfatório. 


\section{Conclusão}

O presente estudo tem como objetivo central a busca por uma resposta sobre a origem e as causas do colapso estatal e as consequentes guerras civis na África Subsaariana. Como foi demonstrado desde o início, as explicações recorrentes sobre tais fenômenos não satisfazem pois apontam para uma correlação cujos cenários dela derivados não correspondiam à realidade. Afinal, apesar de a grande maioria dos países na África Subsaariana serem subdesenvolvidos, tal fato não resultou em processos generalizados de colapso estatal e, quando houve, o restabelecimento da paz raramente foi acompanhado ou precedido de melhorias no desenvolvimento.

Apesar de o sucesso e o fracasso dos Estados serem geralmente medidos em termos de sua autoridade, legitimidade e desenvolvimento, a maior parte da literatura sempre pendeu para o último como fator determinante para manutenção da paz ou eclosão das guerras nos países da região. Além disso, a parte da literatura que visou a apontar múltiplos fatores como causas desses fenômenos fê-lo destacando, no geral, questões diretamente relacionadas ao subdesenvolvimento, tais como a privação relativa e a relação entre ganância e queixa, ignorando assim a questão da estrutura. De modo geral, esta literatura apontou para a agência, isto é, na disposição e capacidade dos indivíduos e atores políticos de agir e tomar decisões independentemente. Além disso, conforme foi demonstrado no capítulo 1, a securitização do desenvolvimento obedeceu a dinâmicas históricas precisas e acabaram representando muito mais os anseios políticos de diversos atores do que a realidade própria dos fatos.

O objetivo deste estudo foi, contudo, apontar para o fato de que a eclosão de guerras civis ou a sua prevenção variava em função dos níveis de autoridade do Estado em questão. Isto é, a capacidade de o governo e das instituições de um Estado em garantir a ausência de violência política e terrorismo, em assegurar a nomocracia e desempenhar efetivamente sua governança determinariam o sucesso ou o fracasso do Estado, chegando, em seu extremo negativo, ao seu colapso e às guerras civis. Ao contrário da leitura mais recorrente, esta visão alternativa aqui proposta tem como base a estrutura, que determina o comportamento dos agentes, ampliando ou constrangendo as oportunidades de ação e o leque de escolhas disponíveis dos atores políticos. 
Como foi demonstrado no capítulo 2, a autoridade estatal é a variável da estrutura que constrange o comportamento dos atores. Assim, demonstrou-se que a eclosão dos conflitos intraestatais e a preservação da paz doméstica nos Estados da África Subsaariana estavam muito mais ligados às alterações em dita variável do que em qualquer outro elemento. Os casos de Ruanda, Libéria e Costa do Marfim foram ilustrativos neste ponto. Todos eles tiveram dinâmicas desenvolvimentistas distintas, mas coincidiram na evolução da autoridade estatal tanto para a eclosão de seus conflitos quanto para a sua pacificação. Neste sentido, buscou-se demonstrar também que a autoridade estatal estava fundada não apenas nos recursos que os Estados detêm para fazer valer e exigir o cumprimento de suas leis, mas também na própria ideia de "partilha de botim". Além disso, indicou-se que a continuidade das civilizações e a existência de lideranças tradicionais podiam desempenhar um papel dúbio, fortalecendo ou concorrendo com o Estado e, assim, sendo mais um fator capaz de alterar a autoridade estatal.

Desta monta, é correto, por um lado, afirmar que os motivos para o surgimento de guerras civis e do colapso de Estados na África Subsaariana sugeridos neste estudo substituem uma explicação monocausal por outra. Afinal, as explicações que destacam supostas multicausalidades para o fenômeno estudado estão todas relacionadas com a questão do (sub)desenvolvimento e, indubitavelmente, inserem-se em uma leitura que privilegia a agência em detrimento da estrutura. Ou seja, elas também são monocausais. Desta forma, não se pode dizer que este trabalho foca na autoridade estatal simplesmente deixando de lado uma série de causas fundamentais e fatores desencadeantes, mas sim que rechaça as explicações com base na agência e apresenta uma leitura estruturalista sobre a falência dos Estados e as consequentes guerras civis. Como se afirmou em diversos momentos, é a estrutura que define o modo de ação dos agentes nos países da África Subsaariana: sua força determina se agirão pela via das regras ou pela via das armas e quando a resultante das forças da agência e da estrutura pendeu no sentido da primeira, optou-se pela segunda via. Isto é, quando a autoridade estatal atingiu níveis muito baixos, a estrutura foi comprometida de modo a encorajar que os agentes optassem pela via armada.

Por outro lado, falar em monocausalidade pode não ser preciso. Se são vários os fatores que interferem a agência, também a estrutura é composta por uma percepção de autoridade composta de três características (ausência de violência política e terrorismo, eficácia da governança e nomocracia) e uma série de fatores que interferem nelas. Além 
disso, viu-se que a legitimidade dos Estados da África Subsaariana tem papel crucial no aumento nos índices de autoridade e no fortalecimento das instituições estatais dos países da região, sendo assim mais um fator a influenciar a estrutura que delimita as possiblidades de ação dos agentes. No tocante a este último fator, notou-se que a legitimidade vertical e a continuidade das civilizações deram contribuições importantíssimas para o incremento da autoridade estatal e a consequente não ocorrência de guerras civis e colapso estatal.

Dos dez países que eram verticalmente legítimos, apenas Burundi, Ruanda e Etiópia passaram por guerras civis em sua história. No entanto, o próprio autor que classificou os países desse jeito não tinha certeza sobre a exatidão de tal classificação para os dois primeiros. ${ }^{191}$ No caso da Etiópia, a expansão territorial levada a cabo no fim do século XIX pelo Imperador Menelik II alterou significativamente a geografia política do país e o golpe de Estado que depôs o Imperador Hailé Selassié I e a mais antiga dinastia do mundo em 1974 representou violência severa às instituições políticas pré-coloniais que ainda existiam, fazendo assim questionar se o país ainda tem legitimidade vertical. Até o fim de 2015, Burundi e Etiópia ainda apresentavam índices altos de violência e, como era de se esperar, níveis baixos de autoridade estatal. Diferentemente deles, Ruanda logrou pôr fim à onda de violência que a assolava por vinte anos em 2012.

É neste sentido que a segunda parte deste trabalho visou a demonstrar com base em casos selecionados que a paz e a guerra ocorreram em função das alterações do nível de autoridade estatal nos países da África Subsaariana. Além de refutar causalidades comumente apontadas pela literatura e relacionadas com a questão desenvolvimentista e da agência, os capítulos 3 e 4, principalmente, trataram de mostrar que os Estados respondem de forma racional e até mesmo padrão às ameaças a suas autoridades. Mesmo os países pacíficos que estavam na categoria dos PMDs e os que não estavam nela agiram, no geral, de modo semelhante à questão do tamanho do território, das lideranças tradicionais, das regras costumeiras e - como já dito - da legitimidade vertical. Neste sentido, as diferenças que apresentam com relação aos países que tiveram conflitos não foram nos níveis de desenvolvimento, mas sim nos de autoridade. Nos 21 países que nunca tiveram guerras civis ou conflitos não-estatais, a estabilidade foi conseguida porque

${ }^{191}$ Englebert (2000b, p. 129). 
fatores históricos e políticas no período pós-colonial garantiram-lhes a capacidade de projetar poder e fazer-se presente em todos os rincões de seus territórios.

Assim sendo, se o subdesenvolvimento não foi causa para guerras, o desenvolvimento tampouco seria a causa para a paz. O modo com o qual Ruanda e outros tantos países reconstruíram seus Estados e evitaram assim novos colapsos e guerras civis não passou pelo desenvolvimento, já que, exceto Angola e Guiné Equatorial, nenhum país da região tem previsão de saída da categoria dos PMDs. Ao contrário, o padrão que se montou nos países que passaram por guerras civis, mas não retornaram ao colapso estatal após a celebração da paz foi de retradicionalização das instituições políticas e da reconstrução do Estado voltada para a estrutura e não para o desenvolvimento. Tal como sucedeu-se em Angola, República do Congo, Libéria e Ruanda, a reconstrução do Estado teve foco principalmente em definir quem era o governo e na reconstrução do aparato coercitivo. Em suma, ou procuraram aproximar suas instituições daquilo que eram anteriormente à chegada dos colonizadores ou buscaram ao máximo modernizá-las.

Estes quatro Estados - de um jeito ou de outro - determinaram quem era o governo, reformaram as forças armadas e aplicaram processo de desmobilização e desarmamento (tendo tido dificuldades e falhas na reintegração dos ex-combatentes). Também fortaleceram a segurança pública e garantiram a livre circulação dos cidadãos sobre o território assim como escreveram nova constituição que definiu a nova organização das instituições estatais. Por fim, investiram em justiça de transição e em instituições indígenas e reformaram a administração pública, tornando o Estado acessível para todos os atores políticos. Fazendo assim, trabalharam justamente no fortalecimento dos três componentes da autoridade estatal. Se é pouco provável que eles voltem a sucumbir a tais dinâmicas destrutivas, o mesmo pode ser dito sobre outros países que percorreram o mesmo caminho. ${ }^{192}$

Esta pesquisa - que se conclui nestas últimas páginas - foi feita durante os anos de 2013 e 2016, período em que havia uma retomada no aumento da quantidade de conflitos na África Subsaariana após uma década de forte queda. ${ }^{193}$ Neste período, a República

\footnotetext{
${ }^{192}$ A Libéria ainda merece atenção quanto a isto. A reconstrução estatal foi feita graças ao investimento e esforços da ONU, cuja intervenção no país ainda está em vigor no momento desta redação. A pergunta que se faz, consequentemente, é se a Libéria conseguirá manter a nova estrutura que é mantida hoje pelas ONU quando a intervenção acabar. Do modo abrangente que a reconstrução do Estado tratou a questão da estrutura estatal e da sua autoridade, há motivos para otimismo com a transição para o pós-UNMIL.

193 Uppsala Conflict Data Program (2016).
} 
Democrática do Congo, a Nigéria, a Somália, o Sudão e o Sudão do Sul passaram por guerras civis, sendo que apenas o primeiro e o último haviam diminuído a quantidade de mortes em 2015 a ponto de rebaixar a classificação da dinâmica destrutiva para conflitos menores. Além disso, nove países passavam naquele ano por conflitos menores que de tão frequentes atingiram pelo menos a cifra de mil mortos ${ }^{194}$ e cinco deles tinham também conflitos não-estatais. ${ }^{195}$ Apesar disto estar fora do período dos dados estatísticos analisados neste trabalho, as informações atualizadas também demonstram queda nos níveis de autoridade desses Estados e que merecem, portanto, uma atenção especial por parte de acadêmicos e atores internacionais.

$\mathrm{O}$ que as experiências no continente mostraram é que não apenas para os Estados mencionados acima, mas também para outros que possam vir a entrar em colapso que o foco na autoridade estatal é imprescindível para a construção de uma ordem política pacífica. Além disso, com base nos 21 países que nunca passaram por guerras civis ou conflitos não-estatais, sugere-se três políticas que tendem a fortalecer a autoridade dos Estados onde forem aplicadas. Primeiro, respeitar processos separatistas quando eles ocorrerem. Ao que se diminua o tamanho dos Estados africanos, será verificado um ajuste na geografia política dos Estados e, assim, a tendência à transição de geografias políticas difíceis para favoráveis à projeção do poder e consolidação da autoridade estatal. Segundo, não impor ou pressionar pela criação e implementação de modos de governança ou instituições não-indígenas. No geral, os países que nunca passaram por guerras civis demonstraram que instituições ocidentais trouxeram mais problemas do que soluções e que precisaram ser ocupadas por uma burocracia composta por líderes tradicionais. Por fim e como consequência da anterior, a retradicionalização das instituições políticas, principalmente nas áreas que mais se fazem presentes e maior influência têm na vida da população (como alocação de terra e resolução de disputas locais). Deste modo, não apenas haverá instituições políticas mais legítimas perante a população como também elas estarão mais próximas do objeto de seu poder, marcando presença e constrangendo ações contra elas.

Estas sugestões de políticas estão em consonância com tendências dos (pelo menos) últimos vinte anos na África Subsaariana. Tendo isto em vista, este trabalho se encerra com um otimismo cauteloso sobre o futuro da região no tocante à paz e à guerra. Ao que

\footnotetext{
${ }^{194}$ Burundi, Camarões, Etiópia, Mali, Nigéria, Somália, Sudão, Sudão do Sul e Uganda.

${ }^{195}$ República Centro-Africana, Quênia, Mali, Sudão e Sudão do Sul.
} 
tudo indica, o processo vigente de acomodação das forças políticas (dos atores políticos) será aprofundado justamente como consequência da tendência de assentamento das instituições políticas tradicionais e pós-coloniais nos Estados da região. Isso significa cada vez mais paz? Talvez. Seguindo estas tendências, a cautela deve ser mantida pelo fato de que ainda há forças e potências não-africanas que exploram o continente e têm interesses em dar poder a elites que lhes favoreçam. Por outro lado, a probabilidade de implosão e colapso dos Estados africanos, ou seja, a chance de uma nova década de 1980, será cada vez menor. Se esses processos continuarem da maneira que estão, pode-se afirmar que mesmo onde ainda houver conflitos, eles serão cada vez restritos a regiões específicas dentro de Estados, disputando-se o controle sobre as instituições locais sem desafiar, contudo, as instituições nacionais ou então lutando pela secessão. O maior desafio dos países da África Subsaariana e de seus estudiosos será garantir que o continente passe a ter uma imagem perante acadêmicos e veículos midiáticos que reflita sua heterogeneidade e sua tendência de assentamento das disputas no longo prazo. Espera-se que este trabalho seja apenas mais um esforço nesse sentido: de que a África Subsaariana tenha uma imagem justa! 


\section{Bibliografia}

Acemoglu, D., \& Robinson, J. A. (2010). Why is Africa poor? Economic History of Developing Regions, 21-50.

Acemoglu, D., \& Robinson, J. A. (2012). Why Nations Fail: the origins of power, prosperity, and poverty. Nova lorque: Crown Publishing.

Acemoglu, D., Johnson, S., \& Robinson, J. A. (2003). An African Success Story: Botswana. Em D. Rodrik, In Search of Prosperity: Analytic Narratives on Economic Growth (pp. 80-122). Princeton: Princeton University Press.

Adebajo, A. (2002). Liberia's Civil War: Nigeria, ECOMOG and Regional Security in West Africa. Boulder: Lynne Rienner.

Adjaye, J. K., \& Misawa, B. (2006). Chieftancy at the Confluence of Tradition and Modernity: Transforming African Rulership in Ghana and Nigeria. International Third World Studies Journal and Review, 1-10.

African Development Bank. (2007). Africa's Natural Resources: the paradox of plenty. Em African Development Report 2007 (pp. 96-141).

African Economic Outlook. (2014). Exports, 2014. Acesso em 21 de Novembro de 2016, disponível em African Economic Outlook - statistics: http://www.africaneconomicoutlook.org/en/statistics

Afrobarometer. (2005, 2009, 2012 e 2015). Ethnic or national identity. Acesso em 06 de Dezembro de 2016, disponível em The online data analysis tool: http://afrobarometer.org/online-data-analysis/analyse-online

Afrobarometer. (2009a). Traditional leaders more or less influence. Acesso em 04 de Dezembro de 2016, disponível em The Online Data Analysis Tool: http://afrobarometer.org/online-data-analysis/analyse-online

Afrobarometer. (2009b). Primary responsibility: solving local disputes. Acesso em 06 de Dezembro de 2016, disponível em The Online Data Analsis Tool: http://afrobarometer.org/online-data-analysis/analyse-online

Afrobarometer. (2009c). Primary responsibility: collecting income taxes. Acesso em 06 de Dezembro de 2016, disponível em The Online Data Analysis Tool: http://afrobarometer.org/online-data-analysis/analyse-online

Afrobarometer. (2009d). Primary responsibility: allocating land. Acesso em 06 de Dezembro de 2016, disponível em The Online Data Analysis Tool: http://afrobarometer.org/onlinedata-analysis/analyse-online

Afrobarometer. (2015). How much do you trust each of the following, or haven't you heard enough about them to say? Traditional leaders. Acesso em 04 de Dezembro de 2016, disponível em The Online Data Analysis Tool: http://afrobarometer.org/online-dataanalysis/analyse-online 
Afrobarometer. (2015). Obey government always vs. only if vote for it. Acesso em 23 de Novembro de 2016, disponível em Afrobarometer - The online data analysis tool: http://www.afrobarometer.org/online-data-analysis/analyse-online

AGNU. (1960). Declaration on the granting of independence to colonial countries and peoples. XV Sessão da Assembleia Geral das Nações Unidas (pp. 66-67). Nova lorque: ONU.

Alvarez, M., Cheibub, J. A., Limongi, F., \& Przeworski, A. (Verão de 1996). Classifying Political Regimes. Studies in Comparative International Development, 31(2), 3-36.

Ankomah, B. (June de 2011). The Trouble with Namibia. New African, pp. 40-44.

Annan, K. (Dezembro de 2001). Nobel Prize.org. Acesso em 11 de 12 de 2014, disponível em Kofi Annan - Nobel Lecture: MLA style: "Kofi Annan - Nobel Lecture". Nobelprize.org. Nobel Media AB 201http://www.nobelprize.org/nobel_prizes/peace/laureates/2001/annanlecture.html

Anstee, M. (1996). Orphan of the Cold War: the inside story of the collapse of the Angolan peace process 1992-93. Londres: Macmillan Press.

Ayoob, M. (1984). Security in the Third World: the worm about to turn? International Affairs, 60(1), 41-51.

Ayoob, M. (1995). The Third World Security Predicament. Boulder: Lynne Rienner.

Ayoob, M. (1997). Defining Security: A Subaltern Realist Perspective. Em K. Krause, \& M. Williams, Critical Security Studies (pp. 121-46). Minneapolis: University of Minnesota Press.

Badié, B. (1992). L'État importé - l'Occidentalism de l'ordre politique. Paris: Fayard.

Baker, B. (2010). Resource Constraint and Policy in Liberia's Post-Conflict Policing. Police Practice and Research: An International Journal, 11(3), 184-196.

Baldwin, K. (2016). The Paradox of Traditional Chiefs in Democratic Africa. Nova lorque: Cambridge University Press.

Banco Mundial. (2015). GNI per capita, Atlas method (current US\$̦). Acesso em 09 de Fevereiro de 2015, disponível em Banco Mundial: http://data.worldbank.org/indicator/NY.GNP.PCAP.CD

Barkawai, T., \& Laffey, M. (2006). The Postcolonial Moment in Security Studies. Review of International Studies, 32(2), 329-52.

Bayart, J.-F. (1996). L'Historicité de l'État Importé. Les Cahiers du CERI, 1-45.

Bayart, J.-F. (1999). L'Afrique dans le monde: une histoire d'extraversion. Critique Internationale, 97-120.

Bayart, J.-F. (2006). L'État en Afrique - la politique du ventre. Paris: Fayard. 
Bazenguissa-Ganga, R. (1999). The spread of political violence in Congo-Brazzaville. African Affairs, 37-54.

Beach, D. N. (1980). The Shona \& Zimbabwe, 900-1850. Africana Pub. Co.

Beach, D. N. (1986). War and Politics in Zimbabwe, 1840-1900. Gweru: Mambo Press.

Beaulier, S., \& Subrick, J. R. (2006). The Political Foundations of Development: the case of Botswana. Constitutional Political Economy, 17(02), 103-115.

Berg, E. J. (1961). Backward-Sloping Labor Supply Functions in Dual Economies - the Africa Case. Quarterly Journal of Economics, pp. 469-92.

Blundo, G. (2001). Négocier l'État au quotidien: agents d'affaire, courtiers et rabbateurs dans les interstices de l'administration sénégalaise. Autrepart, 20, 75-90.

Boudon, R. (1977). La logique de la frustration relative. European Journal of Sociology, 3-26.

Braudel, F. (1985). La Longue Durée. Em F. Braudel, Écrits sur I'histoire (pp. 41-83). Paris: Flammarion.

Braveboy-Wagner, J. A. (2003). The Foreign Policies of the Global South: an introduction. Em J. A. Braveboy-Wagner, The Foreign Policies of the Global South: rethinking conceptual framewords (pp. 1-12). Boulder: Lynne Rienner.

Bresser-Pereira, L. C. (2008). The Dutch disease and its neutraliztion: a Ricardian approach. Revista de Economia Política, d28(1), 47-71.

Buur, L., \& Kyed, H. M. (2007). State Recognition and Democratization in Sub-Saharan Africa: a new dawn for traditional authorities? Nova lorque: Palgrave MacMillan.

Buzan, B., \& Hansen, L. (2012). A evolução dos estudos de segurança internacional. São Paulo: Unesp.

Buzan, B., Waever, O., \& Wilde, J. d. (1998). Security: a new framework for analysis. Londres: Lynne Rienner.

Call, C. T. (2008). The Fallacy of the 'Failed State'. Third World Quarterly, 1491-1507.

Call, C. T. (2010). Beyond the 'failed state': toward conceptual alternatives. European Journal of International Relations, pp. 303-26.

Carment, D., Prest, S., \& Samy, Y. (2010). Security, Development and the Fragile State - bridging the gap between theory and policy. Nova lorque: Routledge.

Castells, M. (1996). The Rise of the Network Society. Massachusetts: Blackwell.

Cederman, L.-E., Min, B., \& Wimmer, A. (2009). Ethnic Power Relations dataset. 
Center for Systemic Peace. (03 de 12 de 2016). Integrated Network for Societal Conflict Research (INSCR). Fonte: Polity IV Project, Political Regime Characteristics and Transitions, 1800-2015: http://www.systemicpeace.org/inscrdata.html

Central Intelligence Agency. (2016). The World Factbook. Acesso em 12 de 11 de 2016, disponível em https://www.cia.gov/library/publications/the-world-factbook/

Chabal, P., \& Daloz, J.-P. (2001). Africa camina: el desorden como instrumento político. Barcelona: Ballesterra.

Chabal, P., Birmingham, D., Forrest, J., Newitt, M., Seibert, G., \& Andrade, E. S. (2002). A History of Postocolonial Lusophone Africa. Londres: Hurst \& Company.

Chiweza, A. L. (2007). The Ambivalent Role of Chiefs: Rural Decentralization Initiatives in Malawi. Em L. Buur, \& H. M. Kyed, State Recognition and Democratization in SubSaharan Africa: a new dawn for traditional authorities? (pp. 53-78). Nova lorque: Palgrave MacMillan.

Cilliers, J. (2015). Future (im)perfect? Mapping conflict, violence and extremism in Africa. Institute for Security Studies.

Clapham, C. (1996). Africa and the International System: the politics of state survival. Cambridge: Cambridge University Press.

Clapham, C. (Abril de 1998a). Degrees of Statehood. Review of International Relations.

Clapham, C. (1998b). Discerning the New African. International Affairs, pp. 263-70.

Clapham, C. (2000). Guerre et construction de l'État dans la Corne de l'Afrique. Critique Internationale, pp. 95-111.

Clapham, C. (2009). Liberia and Sierra Leone: an essay in comparative politics. Cambridge: Cambridge University Press.

Clapham, C., Herbst, J., \& Mills, G. (2006). Big African States. Johannesburg: Wits University Press.

Clark, P. (2010). The Gacaca Courts, Post-Genocide Justice and Reconciliation in Rwanda Justice without lawyers. Cambridge: Cambridge University Press.

Correia, P. (1991). Descolonização de Angola: a joia da Coroa do Império Português. Luanda: Ler \& Escrever.

Cox, R. W. (1987). Production, Power and World Order: social forces in the making of history. Nova Iorque: Columbia University Press.

Cypher, J. M., \& Dietz, J. L. (2004). Developmentalist Theories of Economic Development. Em J. M. Cypher, The Process of Economic Development (pp. 140-67). Abingdon: Routledge.

Dallaire, R. (2003). Shaking Hands with the Devil: The Failure of Humanity in Rwanda. Nova lorque: Carroll \& Graff. 
DFID. (1997). Eliminating World Poverty: a challenge for the 21st century. Londres: Department for International Development.

Dialogue, S. (2004). Spectial Section: What is 'Human Security'? Security Dialogue, 35, pp. 34571.

Dolo, E. (1996). Democracy Versus Dictatorship: The Quest for Freedom and Justice in Africa's Oldest Republic - Liberia. Lanham: University Press of America.

Döpcke, W. (1999). A Vida Longa das Linhas Retas: cinco mitos sobre as fronteiras na África Negra. Revista Brasileira de Política Internacional, 77-109.

Doyle, M. W. (Agosto de 2005). Three Pillars of the Liberal Peace. The American Political Science Review, 99(3), 463-466.

du Pisani, A. (2000). State and Society under South African Rule. Em C. Keulder, State, Society and Democracy: a reader in Namibian politics (pp. 49-76). Windhoek: Macmillan Education Namibia.

Duffield, M. (2001). Global Governance and the New Wars. Londres: Zed Books.

Dunn, K. C. (2001). MadLib \#32: The (Blank) African State: Rethinking the Sovereign State in International Relations Theory. Em K. C. Dunn, \& T. M. Shaw, Africa's Challenge to International Relations Theory (pp. 46-63). Nova lorque: Palgrave.

Duyvesteyn, I. (2005). Clausweitz and African War: politics and strategy in Liberia and Somalia. Abingdon: Taylor \& Francis.

Easterly, W. (2001). The elusive quest for growth: economists' adventures and misadventures in the tropics. Cambridge: The MIT Press.

Englebert, P. (2000a). Pre-colonial Institutions, Post-Colonial States, and Economic Development in Tropical Africa. Political Research Quarterly, 7-36.

Englebert, P. (2000b). State Legitimacy and Development in Africa. Boulder: Lyenne Ryenner.

Englebert, P. (2002). Patterns and Theories of Traditional Resurgence in Tropical Africa. Mondes en développement, 118(2), 51-64.

Englebert, P. (2005). Compliance and defiance to national integration in Barotseland and Casamance. Afrika Spectrum, 39(1), 29-59.

Englebert, P. (2009). Africa: unity, sovereignty, and sorrow. Boulder: Lynne Rienner.

FAO. (s.d.). Equatorial Guinea. Acesso em 02 de Dezembro de 2016, disponível em Gender and Land Rights Database: http://www.fao.org/gender-landrights-database/countryprofiles/countries-list/land-tenure-and-related-institutions/en/?country_iso3=GNQ

FAO. (s.d.). Eritrea. Acesso em 02 de Dezembro de 2016, disponível em Gender and Land Rights Database: http://www.fao.org/gender-landrights-database/countryprofiles/countries-list/land-tenure-and-related-institutions/en/?country_iso3=ERI 
FAO. (s.d.). Gender and Land Rights Database. Acesso em 12 de 12 de 2016, disponível em Lesotho: http://www.fao.org/gender-landrights-database/country-profiles/countrieslist/land-tenure-and-related-institutions/en/?country_iso3=LSO

FAO. (s.d.). Malawi. Acesso em 02 de Dezembro de 2016, disponível em Gender and Land Rights Database: http://www.fao.org/gender-landrights-database/countryprofiles/countries-list/land-tenure-and-related-institutions/en/?country_iso3=MWI

Fondation pour les Études et Recherces sur le Développement International. (2015). Acesso em 09 de February de 2015, disponível em http://www.ferdi.fr/fr/node

Frank, A. G. (1967). Sociology of Development and the Underdevelopment of Sociology. Catalyst, 20-73.

Fukuyama, F. (2005). Construção de estados: governo e organização mundial no século XXI. Rio de Janeiro: Rocco.

Fukuyama, F. (2011). As Origens da Ordem Política: dos tempos pré-humanos até a Revolução Francesa. Rio de Janeiro: Rocco.

Fund for Peace. (2014). Fragile States Index 2014. Acesso em 03 de junho de 2015, disponível em Fund for Peace: http://fsi.fundforpeace.org/

Gentili, A. M. (2012). El león y el cazador: historia del África Subsahariana. Buenos Aires: CLACSO.

Gervais, R., \& Mande, I. (2000). From Crisis to National Identity: Migration in Mutation, Burkina Faso, 1930-1960. International Journal of African Historical Studies, 12(3), 59-79.

Girod, J. (1994). L'Énergie en Afrique - la situation énergétique de 34 pays de I"Afrique subsaharienne et du Nord. Paris: Karthala.

Global Firepower. (01 de Abril de 2016). Global Firepower Ranking 2016. Acesso em 01 de Novembro de 2016, disponível em Global Firepower:

http://www.globalfirepower.com/countries-listing.asp

Grimm, S., Lemay-Hébert, N., \& Nay, O. (2014). 'Fragile States': introducing a political concept. Third World Quarterly, 197-209.

Grovogui, S. N. (2001). Sovereignty in Africa: Quase-Statehood and Other Myths in International Theory. Em K. C. Dunn, \& T. M. Shaw, Africa's Challenge to International Relations Theory (pp. 29-45). Nova lorque: Palgrave.

Gurr, T. R. (1980). Handbook of Political Conflict. Nova lorque: Free Press.

Gurr, T. R. (1986). The Political Origins of State Violence and Terror: a theoretical analysis. Em M. Stohl, \& G. A. Lopez, Government, Violence and Repression: an agenda for research (p. 278). Westport: Greenwood Press.

Gurr, T. R. (2011a). Why Men Rebel. Paradigm Publishers. 
Gurr, T. R. (17 de Novembro de 2011b). Why Men Rebel Redux: how valid are its arguments 40 years on. Acesso em 02 de Julho de 2015, disponível em E-International Relations: http://www.e-ir.info/2011/11/17/why-men-rebel-redux-how-valid-are-its-arguments40-years-on/

Hagberg, S. (2007). Traditional Chieftancy, Party Politics, and Political Violence in Burkina Faso. Em L. Burr, \& H. M. Kyed, State Recognition and Democratization in Sub-Saharan Africa: a new dawn for traditional authorities? (pp. 131-54). Nova lorque: Palgrave MacMillan.

Hagmann, T. (2007). Bringing the Sultan Back In: elders as peacemakers in Ethiopia's Somali region. Em L. Burr, \& H. M. Kyed, Sate Recognition and Democratization in SubSaharan Africa: a new dawn for traditional authorities? (pp. 31-52). Nova lorque: Palgrave MacMillan.

Hance, W. A. (1954). Potentialities of the Central African Federation. Political Science Quarterly, 69(1), 29-44.

Hanson, S. (16 de Fevereiro de 2007). Disarmament, Demobilization, and Reintegration (DDR) in Africa. Acesso em 29 de Outubro de 2016, disponível em Council on Foreign Relations: http://www.cfr.org/world/disarmament-demobilization-reintegration-ddrafrica/p12650

Harms, R. (1987). Games Against Nature: an eco-cultural history of the Nunu of Equatorial Africa. New Haven: Yale University Press.

Hegre, H., \& Sambanis, N. (2006). Sensititivy Analysis of Empirical Results on Civil War Onset. Journal of Conflict Resolution, 50(4), 508-535.

Helman, G. B., \& Ratner, S. R. (1993). Saving Failed States. Foreign Policy, 3-20.

Herbst, J. (2000). States and Power in Africa: comparative lessons in authority and control. Princeton: Princeton University Press.

Herbst, J. (2004). Let Them Fail: State Failure in Theory and Practice: Implications for Policy. Em R. I. Rotberg, When States Fail: causes and consequences (pp. 302-18). Princeton: Princeton University Press.

Hesseling, G. (2000). Histoire politique du Sénégal : institutions, droit et société. Paris: Karthala.

Holm, J. (1993). Political Culture and Democracy: A Study of Mass Participation in Botswana. Em S. Stedman, Botswana: the Political Economyof Democratic Development (pp. 91112). Boulder: Lynne Rienner.

Holsti, K. J. (1996). The State, War, and the State of War. Cambridge: Cambridge University Press.

Howe, H. (1996). Lessos of Liberia: ECOMOG and Regional Peacekeeping. International Security, 21(3), 145-176. 
Huband, M. (2004). África después de la Guerra Fría: la promessa rota de un continente. Barcelona: Paidós.

(2007). Human Security Brief. Vancouver: Simon Fraser University.

Huntington, S. (1968). Political Order in Changing Societies. New Haven: Yale University Press.

Ibhawoh, B., \& Dibua, J. I. (2003). Deconstructing Ujamaa: The Legacy of Julius Nyerere in the Quest for Social and Economic Development in Africa. African Journal of Political Science, 8(1), 59-83.

Ibott, R. (2014). Ujamaa - the hidden story of Tanzania's socialist villages. Londres: Crossroads Books.

Inflação do Zimbábue pode ter superado 89 sextilhões por cento, diz instituto. (01 de Março de 2009). Acesso em 18 de Dezembro de 2016, disponível em Globo.com: http://g1.globo.com/Noticias/Economia_Negocios/0,,MUL1012166-9356,00INFLACAO+DO+ZIMBABUE+PODE+TER+SUPERADO+SEXTILHOES+POR+CENTO+DIZ+INS TITUTO.html

Instituto Nacional de Estatística. (2010). DISTRIBUIÇÃO ESPACIAL DA POPULAÇÃO SÃOTOMENSE, 1991/2001-2010. Acesso em 26 de Novembro de 2016, disponível em Instituto Nacional de Estatística da República Democrática de São Tomé e Príncipe: http://www.ine.st/Documentacao/InformacoesEstatisticas/Demograficas/21.pdf

International Monetary Fund. (08 de Junho de 1996). Press Release: IMF Approves Three-Year Loan for the Congo Under the ESAF. Acesso em 11 de Outubro de 2016, disponível em https://www.imf.org/en/News/Articles/2015/09/14/01/49/pr9636

International Monetary Fund. (04 de Outubro de 2016). World Economic Outlook Databases October 2016. Acesso em 10 de Outubro de 2016, disponível em International Monetary Fund:

http://www.imf.org/external/pubs/ft/weo/2016/02/weodata/index.aspx

Isichei, E. A. (1997). A History of African Societies to 1870. Cambridge: Cambridge University Press.

Ivie, R. L. (September de 1999). Fire, Flood, and Red Fever: Motivating Metaphors of Global Emergency in the Truman Doctrine Speech. Presidential Studies Quarterly, pp. 570-91.

Jackson, R. (1990). Quasi-states: sovereignty, international relations and the Third World. Cambridge: Cambridge University Press.

Jackson, R., \& Rosberg, C. G. (Outubro de 1982). Why Africa's weak states persist: the empirical and the juridical in statehood. World Politics, pp. 1-24.

Jennings, K. M. (2007). The Struggle to Satisfy: DDR Through the Eyes of Ex-combatants in Liberia. International Peacekeeping, 14(2), 204-2018. 
Johnson, P., \& Korica, S. (2015). Julius Nyerere - Asante sana, Thank you, Mwalimu. Dar es Salaam: House of Books.

Kaplan, R. D. (fevereiro de 1994). The coming anarchy - how scarcity, crime, overpopulation, tribalism, and disease are rapdly destroying the social fabric of our planet. The Atlantic Monthly.

Kapuściński, R. (2005). O Imperador: a queda de um autocrata. São Paulo: Companhia das Letras.

Kauffmann, D., Kraay, A., \& Mastruzzi, M. (2010). The Worldwide Governance Indicators. The World Bank.

Keulder, C. (2000). Traditional Leaders. Em C. Keulder, State, Society and Democracy: a reader in Namibian politics (pp. 150-170). Windhoek: Macmillan Education Namibia.

Kieh, G. K. (2008). The First Liberian Civil War: the crisis of underdevelopment. Nova lorque: Peter Lang.

King, G., \& Zeng, L. (2001). Improving Forecasts of State Failure. World Politics, 623-58.

Kingma, K. (2004). Demobilization, Reintegration and Peace-building in Southern Africa. Em P. Batchelor, \& K. Kingma, Demilitarization and Peace-building in Southern Africa: concepts and processes (Vol. 1, pp. 133-163). Aldershot: Ashgate.

Kingma, K. (2011). The Rwanda Demobilisation and Reintegration Program: Evaluation Report Prepared for the United Nations Development Programme. Quigali: United Nations Development Programme.

Koné, A. (2013). La Guerre civile angolaise de 1991 à 2002. Saint-Denis: Conaissances et Savoir.

Krasner, S. (12 de Abril de 1999). Intervenção e tolerância. Jornal do Brasil.

Krasno, J. (2006). Public Opinion Survey of UNMIL's Work in Liberia. Peacekeeping Best Practices Section.

Krause, K. (1996). Insecurity and State Formation in the Global Military Order: the Middle Eastern case. European Journal of International Relations, 2(3), 319-54.

Lamb, G. (2013). DDR 20 Years Later: historical review of the long-term impact of postindependence DDR in Southern Africa. Washington: The International Bank for Reconstruction and Development / World Bank.

Le Sage, A. (2007). African counterterrorism cooperation: assessing regional and subregional initiatives. Dulles: Potomac Books.

Lemke, D. (2003). African Lessos for International Relations Research. World Politics, pp. 11438.

Lewin, M. (2011). Botswana's Sucess: Good Governance, Good Policies, and Good Luck. Washington: World Bank. 
Lugan, B. (2013). Les Guerres d'Afrique: des origines à nos jours. Clermont-Ferrand: Éditions du Rocher.

Magnusson, B. A., \& Clark, J. F. (2005). Understanding Democratic Survival and Democratic Failure in Africa: Insights from Divergent Democratic Experiments in Benin and Congo (Brazzaville). Comparative Studies in Society and History, 47, 552-82.

Maipose, G. S. (2008). Institutional Dynamics of Sustained Rapid Economic Growth with Limited Impact on Poverty Reduction. Genebra: UNRISD.

Malaquias, A. (2001). Reformulating International Relations Theory: African Insights and Challenges. Em K. C. Dunn, \& T. M. Shaw, Africa's Challenge to International Relations Theory (pp. 11-28). Nova lorque: Palgrave.

Mamdani, M. (1996). Citzen and Subject: contemporary Africa and the legacy of late colonialism. Princeton: Princeton University Press.

Mamdani, M. (Outubro de 2001). Beyond settler and native as political identities: overcoming the political legacy of colonialism. Comparative Studies in Society and History, pp. 651664.

Mapedza, E. (2007). Traditional Authority: accountability and governance in Zimbabwe. Em L. Buur, \& H. M. Kyed, State Recognition and Democratization in Sub-Saharan Africa: a new dawn for traditional authorities (pp. 183-208). Nova lorque: Palgrave MacMillan.

Marinelli, L. (1964). Libera's Open Door Policy. Journal of Modern African Studies, 91-98.

Martin, D.-C. (1988). Tanzanie: l'invention d'une culture politique. Paris: Karthala.

Mazrui, A. A. (2008). Conflict in Africa: an overview. Em A. Nhema, \& P. T. Zeleza, The roots of African conflicts - the causes and costs (pp. 36-50). Oxford: OSSREA.

Mbabazi, P., \& Taylor, I. (2005). The Potentiality of "Developmental States" in Africa: Botswana and Uganda. Dacar: CODESRIA.

MDRP. (Maio de 2007). Monthly Statistical Progress Report. Acesso em 14 de 11 de 2016, disponível em Multi-Country Desmobilization and Reintegration Programme: http://tdrp.net/mdrp/PDFs/MSR_05_07_ExSumm.pdf

MDRP. (2007). Monthly Statistical Progress Report: May 2007. Washington: MDRP Secretariat.

MDRP. (Dezembro de 2008). Atividades do MDRP apoiadas em Angola. Acesso em 01 de Novembro de 2016, disponível em Multi-Donor Demobilization and Reintegration Program: http://tdrp.net/mdrp/PDFs/MDRP_ANG_FS_1208_pt.pdf

MDRP. (Julho de 2012). MDRP Final Report - Overview of Program Achievements. Acesso em 01 de 11 de 2016, disponível em Multi-Donor Demobilization and Reintegration Program: http://tdrp.net/mdrp/PDFs/MDRP_Final_Report.pdf 
MDRP. (Julho de 2012). Republic of Congo. Acesso em 07 de Novembro de 20106, disponível em Multi-Donor Reintegration Program: http://tdrp.net/mdrp/republic.htm

Mehreteab, A. (2005). Rwanda Demobilization and Reintegration Program. Quigali: Rwanda Demobilization and Reintegration Commission.

Melber, H. (2009). One Namibia, One Nation? The Caprivi as Contested Territory. Journal of Contemporary African Studies, 27(4), 463-481.

Melber, H. (2010). Namibia's National Assembly and Presidential Election 2009: Did Democracy Win? Journal of Contemporary African Studies, 28(2), 203-14.

Melber, H. (Março de 2011). Namibia: A Trust Betrayed - Again? Review of African Political Economy, 103-111.

Menkhaus, K. J. (2006). Governance without government in Somalia - spoilers, state building, and the poltics of coping. International Security, 74-106.

Merry, S. (1987). Disputing without Culture. Harvard Law Review, 2057-73.

Messiant, C. (2004). Why did Bicesse and Lusaka Fail? A critical analysis. Acesso em 31 de Outubro de 2016, disponível em Conciliation Resource: http://www.c-r.org/accordarticle/why-did-bicesse-and-lusaka-fail-critical-analysis

Migdal, J. S. (2011). Estados débiles, Estados fuertes. Cidade do México: Fondo de Cultura Económica.

Miller, P. D. (2013). Armed State Building: confronting state failure, 1898-2012. Nova lorque: Cornell University Press.

Mills, G. (2014). Why States Recover: changing walking societies into winning nations, from Afghanistan to Zimbabwe. London: C. Hurst \& Co.

MoCTA. (s.d.). House of Chiefs. Acesso em 05 de Dezembro de 2016, disponível em Ministry of Chiefs and Traditional Affairs: http://www.mocta.gov.zm/index.php/house-of-chiefs

Monroe, J. C. (2010). Power by design: Architecture and politics in precolonial Dahomey. Journal of Social Archaeology, 10(3), 367-397.

Moore, S. F. (1996). Post-Socialist Micro-Politics: Kilimanjaro, 1993. Africa, 66(4), 587-606.

Morgenthau, H. J. (1962). A Political Theory of Foreign Aid. American Political Science Review, 201-309.

Morgenthau, H. J. (2003). A Política entre as Nações. São Paulo: Editora Oficial do Estado de São Paulo.

Morrison, D., Mitchell, R., \& Paden, J. (1989). Black Africa: a comparative handbook. Nova lorque: Paragon House. 
Moss, T. J. (2011). African Development - making sense of the issues and actors. Boulder: Lynne Rienner.

MRE Suécia. (1997). Preventing Violent Conflict: A Study - executive summary and recommendations. Estocolmo: Ministry of Foreign Affairs.

MRE Suécia. (2000). Preventing Violent conflict - Swedish Policy for the 21st Century. Estocolmo: Ministry of Foreign Affairs.

Muggah, R. (2004). The anatomy of disarmament, demobilisation and reintegration in the Republic of Congo. Conflic, Security \& Development, 21-37.

Muggah, R., Maughan, P., \& Bugnion, C. (2003). The Long Shadow of War: Prospects for Disarmament Demobilisation and Reintegration in the Republic of congo. OCDE.

Munive, J., \& Jakobsen, S. F. (2012). Revisitng DDR in Liberia: exploring the power, agency and interests of local and international actors in the 'making' and 'unmaking' of combatants. Conflict, Security \& Development, 12(4), 359-385.

Muriaas, R. (2009). Local Perspectives on the 'Neutrality' of Traditional Authorities in Malawi, South Africa and Uganda. Commonwealth \& Comparative Politics, 47(1), 28-51.

Mutharika, A. (1998). Some thoughts on Rebuilding African State Capability. Washington University Law Review, 76(1), 281-291.

Nasser, R. M. (2009). Os Estados Falidos: novas ameaças e novas oportunidades. Em R. M. Nasser, Os conflitos internacionais em suas múltiplas dimensões (pp. 115-24). São Paulo: Unesp.

National Security Council. (2002). The National Security Strategy of the United States of America. Washington: The White House.

Negash, T., \& Tronvoll, K. (2000). Brothers at War: making sense of the Eritrean-Ethiopian war. Oxford: Ohio University Press.

Novati, G. C., \& Valescchi, P. (2005). Africa: la storia ritrovata. Roma: Carocci.

OCDE. (2011). International Engagement in Fragile States: Can't We Do Better? Paris.

Omer-Cooper, J. D. (1987). History of Southern Africa. Portsmouth: Heinemann.

ONU. (1981). Study on Human Rights and Massive Exoduses. Nova lorque: Organização das Nações Unidas.

ONU. (1986). Report of the Group of Governmental Experts on International Cooperation to Avert New Flows of Refugees. Nova lorque: Organização das Nações Unidas.

ONU. (1992). An agenda for peace: preventive diplomacy, peacemaking and peace-keeping. Relatório do Secretário-Geral nos termos da declaração aprovada pelo encontro de cúpula do Conselho de Segurança em 21 de Janeiro de 1992, Nova lorque. 
ONU. (19 de Abril de 2010). Twelfth United Nations Congress on Crime Prevention and Criminal Justice. Acesso em 08 de Dezembro de 2016, disponível em United Nations: http://www.un.org/en/conf/crimecongress2010/index.shtml

ONU. (2016). The Peace Agreement Database. Acesso em 18 de Dezembro de 2016, disponível em United Nations Peacemaker: http://peacemaker.un.org/

Orizio, R. (2000). Namibia: how the Blasters lost the promised land. Em R. Orizio, Lost White Tribes: The End of Privilege and the Last Colonials in Sri Lanka, Jamaica, Brazil, Haiti, Namibia and Guadeloupe (pp. 96-123). Nova lorque: The Free Press.

Paes, W.-c. (2005). The challenges of disarmament, demobilization and reintegration in Liberia. International Peacekeeping, 259-261.

Paris, R. (2001). Human Security: paradigm shfit or hot air. International Security, 26, pp. 87102.

Porto, J. G., Alden, C., \& Parsons, I. (2007). From Soldiers to Citizens: demilitarization of conflict and society. Hampshire: Ashgate.

Posner, D. (2004). Measuring Ethnic Fractionalization in Africa. American Journal of Political Science, 48(4), 849-863.

Pratt, C. (1999). Julius Nyerere: Reflections on the Legacy of His Socialism. Canadian Journal of African Studies / Revue Canadienne des Études Africaines, 33(1), 137-152.

Pritchett, L. (1999). The Tiranny of Concepts: Cumulative Depreciated Investment Effort (CUDIE) Is Not the Same as Capital Accumulation. World Bank.

Pritchett, L., \& Woolcock, M. (2002). Solutions When the Solution is the Problem: Arraying the Disarray in Development. Washington: Center for Global Development - Workin Paper 10.

Prunier, G. (2009). Africa's World War: Congo, the Rwandan Genocide, and the making of a continental catastrophe. Nova lorque: Oxford.

Pruntier, G. (1995). The Rwandan Crisis: history of a genocide. Londres: C. Hurst \& Co.

Pugel, J. (2006). Key Findings from the Nation Wide Survey of Ex Combatants in Liberia: Reintegration and Reconciliation. United Nations Develpment Programme - Joint Implementation Unit.

Pureza, J. M. (2009). Segurança Humana: Vinho Novo em Odres Velhos? Em R. M. Nasser, Os conflitos internacionais em suas múltiplas dimensões (pp. 21-34). São Paulo: Unesp.

Ramsbotham, O., Woodhouse, T., \& Miall, H. (2011). Contemporary Conflict Resolution - the prevention, management and transformation of deadly conflicts. Cambridge: Polity Press. 
Ray, D. I., \& van Nieuwaal, E. A. (1996). The New Relevance of Traditional Authorities in Africa. The Journal of Legal Pluralism and Unofficial Law, 1-38.

RDRC. (Março de 2006). Annual Report for 2005. Acesso em 14 de 11 de 2016, disponível em Multi-Country Reintegration Programme: http://tdrp.net/mdrp/PDFs/Sum_RDRP_05_Final_rep.pdf

Reno, W. (1993). Economic Reform and the Strange Case of "Liberalization" in Sierra Leone. Governance, 23-42.

Riedl, R. B. (2014). Authoritarian Origins of Demcoratic Party Systems in Africa. Nova lorque: Cambridge University Press.

Risse, T. (2011). Governance in Areas of Limited Statehood - introduction and overview. In T. Risse, Governance without a State (pp. 1-35). New York: Columbia University Press.

Rosenau, J. N. (1989). The State in an Era of Cascading Politics. Em J. A. Caporaso, The Elusive State: international and comparative perspectives. Newbury Park: Sage.

Rosenau, J. N. (1990). Turbulence in World Politics. Princeton: Princeton University Press.

Rotberg, R. I. (2004). When States Fail: Causes and Consequences. Princeton: Princeton University Press.

Rotberg, R. I. (2005). Battling Terrorism in the Horn of Africa. Cambridge: World Peace Foundation.

Rothchild, D. (2005). Assessing Africa's Two-Phase Peace Implementation Process: Powersharing and Democratization. Em P. Chabal, U. Engel, \& A.-M. Gentili, Is Violence Inevitable in Africa? Theories of Conflict and Approaches to Conflict Prevention (pp. 147-170). Leiden: Brill.

Sawyer, A. (2004). Violent Conflics and governance challenges in West Africa. Journal of Modern African Studies, 42(3), 437-63.

Schoultz, L. (2000). Estados Unidos - poder e submissão. Bauru: EDUSC.

Secretary of State George Marshall Announces a Plan to Save War-Ravaged Europe from Descending into "Chaos". (1999). Em R. Torricelli, \& A. Carroll, In Our Own Words: Extraordinary Speeches of the American Century (pp. 163-66). Nova lorque: Pocket Books.

Serrano, C. (2009). Angola, nascimento de uma nção: um estudo sobre construção de identidade nacional. Luanda: Edições Kilombelembe.

Serrano, C., \& Waldman, M. (2007). Memória D'áfrica - A Temática Africana em Sala de Aula. São Paulo: Cortez.

Sindjoun, L. (2002). Sociologie des relations internationales africaines. Paris: Karthala. 
Sisk, T. D. (2009). International Mediation in Civi Wars: bargaining with bullets. Nova lorque: Routledge.

Snyman, D. (2013). Onder die Radar: stories uit ons land. Cidade do Cabo: Tafelberg.

Sosala, H. K. (10 de Julho de 2014). War on the chieftaincy. Acesso em 05 de Dezembro de 2016, disponível em House of Chiefs - tradition, politics and development: http://www.houseofchiefs.com/2014/07/war-on-chieftaincy.html\#more

Spear, J., \& Williams, P. D. (2012). Security and Development in Global Politics: a critical comparison. Washington: Georgetown University Press.

Stassen, N. (2010). Die Dorslandtrekke na Angola en die redes daarvoor (1874-1928). Historia, 55(1), 32-54.

Statistics Mauritius. (2013). Population and Vital Statistics. Acesso em 23 de Julho de 2016, disponível em Statistics Mauritius: http://statsmauritius.govmu.org/English/Documents/ei1058/population.pdf

Stockholm International Peace Research Institute. (2016). SIPRI Yearbook 2015. Estocolmo.

Suhrke, A. (1994). Towards a Comprehensive Refugee Policy: conflicts and refugees in the postCold War world. Em W. R. Böhning, \& M. L. Schloeter-Paredes, Aid in Place of Migration? Selected contribution an ILO-UNHCR meeting (pp. 13-38). Genebra: International Labour Office.

Suhrke, A. (1999). Human Security and the Interests of the State. Security Dialogue, 30, pp. 265-76.

Suhrke, A., \& Jones, B. (2000). Preventive Diplomacy in Rwanda: failure to act or failure of actions? Em B. W. Jentleson, \& L. H. Hamilton, Opportunities Missed, Opportunities Seized: preventive diplomacy in the post-Cold War world (pp. 238-264). Lanham: Rowman and Littlefield.

The Arusha Declaration and the TANU'S Policy on Socialism and Self-Reliance. (1967). Acesso em 25 de Novembro de 2016, disponível em Friedrich : http://library.fes.de/fulltext/bibliothek/2-tanzania-s0019634.pdf

The Avalon Project. (12 de Março de 1947). President Harry S. Truman's Address Before a Joint Session of Congress, March 12, 1947. Acesso em 17 de Abril de 2015, disponível em Yale Law School: http://avalon.law.yale.edu/20th_century/trudoc.asp

The Marshall Foundation. (03 de Abril de 1948). Foreign Assistance Act of 1948. Acesso em 17 de Abril de 2015, disponível em The Marshall Foundation: http://marshallfoundation.org/library/wpcontent/uploads/sites/16/2014/06/Foreign_Assistance_Act_of_1948.pdf

The South African Institute of International Affairs. (1981). North-South Issues: the Cancun Summit and other 1981 negotiations. Braamfontein: The South Africn Institute of International Affairs. 
Themnér, A. (2011). Violence in Post-Conflict Societies: Remarginalization, Remobilizers and Relationships. Nova lorque: Routledge.

Themnér, L., \& Wallensteen, P. (2014). Armed Conflict, 1946-2013. Journal of Peace Research, 51, pp. 02-51.

Thorton, J. (1998). Africa and Africans in the Making of the Atlantic World. 1400-1800. Cambridge: Cambridge University Press.

Tiendrebeogo, Y. (1963). Histoire Traditionelle des Mossi de Ouagadougou. Journal de la Société des Africanistes, 33(1), 7-46.

Tikuisis, P., Carment, D., Samy, Y., \& Landry, J. (2014). Predicting Fragility and Failure: the evolution of states: 1996-2010. International Studies Association 55th Annual Convention.

Tilly, C. (1990). Coercion, Capital, and European States, A.D. 990-1990. Cambridge: Blackwell.

Tordoff, W. (2002). Government and Politics in Africa. Nova lorque: Palgrave MacMillan.

Tötemeyer, G. (2000). Decentralisation and State-Building at the Local Level. Em C. Keulder, State, Society and Democracy: a reader in Namibian politics (pp. 108-149). Windhoek: Macmillan Education Namibia.

Touval, S. (1972). The Boundary Politics of Independent Africa. Cambridge: Harvard University Press.

Tuck, C. (2000). "Every Car Or Moving Object Gone" The ECOMOG Intervention in Liberia. African Studies Quarterly, 4(1), 1-16.

UNCTAD. (1964). Proceedings of the United Nations Conference on Trade and Development Volume I. Genebra: United Nations.

UNCTAD. (2013). The Least Developed Countries Report 2013. Nova lorque: United Nations.

União Europeia. (2003). The 2003 European Union Security Strategy. Bruxelas.

United Nations Country Team Ethiopia. (2012). Assessing Progress Towards the Millenium Development Goals. Ethiopia MDGs Report 2012.

United Nations Development Programme. (1994). Human Development Report 1994. Nova Iorque: Oxford University Press.

United Nations Development Programme. (2003). Human Development Report 2003. Nova lorque: Oxford University Press.

United Nations Development Programme. (2013). MDG Report 2013 - assessing progress in Africa toward the Millenium Development Goals.

United Nations Economic Commission for Africa, African Union, African Development Bank and United Nations Development Programme. (2014). MDG Report 2014: Assessing 
Progress in Africa toward the Millennium Development Goals. Adis Abeba: ECA Publishing Unit.

United Nations Statistic Division. (31 de Outubro de 2013). Composition of macro geographical (continental) regions, geographical sub-regions, and selected economic and other groupings. Acesso em 05 de Fevereiro de 2015, disponível em United Ntions Statistic Division: http://unstats.org/unsd/methods/m49/m49regin.htm

UNODC. (2013). Global Study on Homicide 2013 - trends, context and data. Genebra: United Nations Office on Drugs and Crime.

UN-OHRLLS. (2015). Criteria for Identification and Graduation of LDCs. Acesso em 09 de February de 2015, disponível em http://unohrlls.org/about-Idcs/criteria-for-Idcs/

Uppsala Conflict Data Program. (2016). Uppsala Conflict Data Program. Acesso em 17 de Novembro de 2016, disponível em Department of Peace and Conflcit Research: http://www.pcr.uu.se/research/ucdp/

van Rouveroy, E. A. (1987). Chef coutumier : um métier difficile. Politique Africaine, 27, 19-30.

Vines, A., \& Oruitemeka, B. (2009). Beyond Bullets and Ballots: the reintegration of UNITA in Angola. Em M. Berdal, \& D. H. Ucko, Reintegrating Armed Groups After Conflict politics, violence and transition (pp. 199-223). Nova lorque: Routledge.

Visentini, P. F. (2012). As revoluções africanas - Angola, Moçambique e Etiópia. São Paulo: Unesp.

Vlassenroot, K., \& Raeymaekers, T. (2004). The Politics of Rebellion and Internvention in Ituri: the emergence of a new political complex? African Affairs, 385-412.

Waever, O. (1995). Securitization and Desecuritization. Em R. D. Lipschutz, On Security (pp. 4686). Nova lorque: Columbia University Press.

Wallerstein, I. M. (2005). Africa: The Politics of Independence and Unity. Lincoln: University of Nebraska Press.

Wendt, A. (1999). Social Theory of International Politics. Cambridge: Cambridge University Press.

Wilks, I. (1975). Asante in the Nineteenth Century: the structure and evolution of a political order. Cambridge: Cambridge University Press.

Williams, F. N. (1994). Precolonial Communities of Southwestern Africa: a history of Owambo kingdoms 1600-1920. Windhoek: National Archives.

Williams, P. D. (2011). War \& Conflict in Africa (e-book). Cambridge: Polity Press.

Woodward, P. (2003). The Horn of Africa - politics and international relations. Nova lorque: I. B. Tauris. 
World Bank. (14 de Dezembro de 2005). Technical Annex for a Program of US\$17 Million from the MDRP Multi-Donor Trust Fund to the Republic of Congo for an Emergency Reintegration Program. Acesso em 06 de Novembro de 2016, disponível em MultiDonor Demobilization and Reintegration Program: http://tdrp.net/mdrp/PDFs/Country_PDFs/ROC-MDRP-TechAnnex_0506.pdf

World Bank. (2011). Conflict, Security and Development. World Development Report 2011, Washington.

World Bank. (2015). GDP growth (annual \%). Acesso em 19 de Dezembro de 2016, disponível em The World Bank: http://data.worldbank.org/indicator/NY.GDP.MKTP.KD.ZG

World Bank. (2015). GNI per capita, Atlas method (current US\$\$). Acesso em 09 de February de 2015, disponível em http://data.worldbank.org/indicator/NY.GNP.PCAP.CD

Worldwide Governance Indicators. (2014). The Worldwide Governance Indicators (WGI) project. Acesso em 09 de February de 2015, disponível em http://info.worldbank.org/governance/wgi/index.aspx\#home

Yengo, P. (2006). La guerre civile du Congo-Brazzaville, 1993-2002: "chacun aura sa part". Paris: Karthala.

Zartman, I. W. (1965). The Politics of Boundaries in North and West Africa. Journal of Modern African Studies, 155-173.

Zartman, W. I. (1995). Collapsed States: The Disintegration and Restoration of Legitimate Authority. Boulder: Lynne Rienner.

Zolberg, A. R. (1969). One-party Government in the Ivory Coast. Princeton: Princeton University Press. 


\section{Apêndice I - Indicadores, fontes e definições.}

As variáveis que compõem este estudo são apresentadas abaixo, seguidas de suas definições. O número entre parênteses indica o peso que cada indicador teve no valor final da variável.

-Autoridade - dados coletados no Worldwide Governance Indicators (2014)

○ [GE] Eficácia da governança (1/3): “percepções sobre a qualidade dos serviços públicos, a qualidade do serviço civil e o grau de sua independência de pressões políticas, a qualidade da formulação de política, e a credibilidade dos compromissos do governo a tais políticas" (Kauffmann, Kraay, \& Mastruzzi, 2010, p. 04).

- $[\mathrm{PV}]$ Violência política e a ausência de violência/terrorismo (1/3): "percepções sobre a probabilidade de que o governo será desestabilizado ou derrubado por meios violentos ou inconstitucionais, incluindo violência de motivação política e terrorismo" (Kauffmann, Kraay, \& Mastruzzi, 2010, p. 04).

○ [RL] Nomocracia (1/3): "percepções da medida em que os agentes têm confiança nas regras da sociedade e cumprem-nas, e em particular a qualidade da execução dos contratos, direitos de propriedade, a polícia e os tribunais, bem como a probabilidade de crime e violência" (Kauffmann, Kraay, \& Mastruzzi, 2010, p. 04).

-Desenvolvimento - dados coletados no Banco Mundial (2015) e na Fondation pour les Études et Recherches pour le Développement International - FERDI (2015)

- [INC] Renda nacional bruta per capita, método Atlas (dólar atual) (1/3): "renda nacional bruta, convertida em dólares americanos usando o método Atlas, divido pela população na metade do ano" (World Bank, 2015).

○ $\quad \mathrm{HAI}$ Índice de Recursos Humanos (1/3): "baseado nos indicadores de: (a) nutrição: percentual da população subnutrida; (b) saúde: taxa de mortalidade para crianças de até cinco anos de idade; (c) educação: 
a taxa bruta de escolarização no ensino secundário; e (d) a taxa de alfabetização adulta" (UN-OHRLLS, 2015).

○ [EVI] Índice de Vulnerabilidade Econômica (1/3): "baseado nos indicadores de: (a) tamanho da população; (b) afastamento; (c) concentração de exportação de mercadorias; (d) participação da agricultura, silvicultura e pesca no produto interno bruto; (e) participação da população que vive em zonas costeiras de baixa elevação; (f) a instabilidade das exportações de bens e serviços; (g) vítimas de desastres naturais; e (h) a instabilidade da produção agrícola" (UN-OHRLLS, 2015).

- Guerra e conflito: dados coletados no Uppsala Conflcit Data Program (2016)

○ [GC] Guerra Civil: conflito armado politicamente motivado em que uma das partes é o governo do país e que resulta em 1000 ou mais mortes relacionadas a batalhas em um ano-calendário.

○ $[\mathrm{CM}]$ Conflitos menores: conflito armado politicamente motivado em que uma das partes é o governo do país e que resulta entre 25 e 999 mortes relacionadas a batalhas em um ano-calendário.

- [IA] Intensidade Acumulada: variável binária que classifica o país cujo conflito teve mais de mil mortes relacionadas a batalha desde sua eclosão ou não.

○ [CNE] Conflito não-estatal: "uso de forças armadas entre dois grupos armados organizados, dos quais nenhu é o governo de um Estado, que resulta em pelo menos 25 mortes relacionadas a batalha em um ano.

- Etnias

○ [EPR]: Ethnic Power Relations, quantidade de grupos étnicos politicamente relevantes em um país (Cederman, Min, \& Wimmer, 2009).

○ [PREG]: Political Relevant Ethnic Groups, medida de fragmentação étnica de um país. Menos fragmentado $=0 ;$ mais fragmentado $=1$ (Posner, 2004).

○ [LEGITH]: Legitimidade Horizontal: "medida em que existe um consenso sobre o que constitui a organização política ou sobre a comunidade que o Estado compreende" (Englebert, 2000b, p. 11). A variável foi calculada "ao subtrair de 1 o percentual da população de 
um país (expressa em decimais) que pertence a um grupo étnico que foi dividido em pelo menos dois países pela colonização" (Englebert, 2000b, p. 201). Menos legítimo = 0; mais legítimo $=1$. 


\section{Apêndice II - Dados sobre Autoridade}

País

África do

Sul

Angola

Benim

Botsuana

Burquina

Faso

Burundi

Cabo Verde

Camarões

Chade

Comores

Congo

Congo, RD

Costa do

Marfim

Djibuti

Eritreia

Etiópia

Gabão

Gâmbia

Gana

Guiné

Guiné

Equatoria

Guiné-

Bissau

Lesoto

Libéria

Madagascar

Maláui

Mali

Maurício

Mauritânia

Moçambique

Namíbia

Níger

Nigéria

Quênia

Rep. Centro-

Africana

Ruanda

São Tomé e

Príncipe

Seicheles $\underline{1996} \quad \underline{1997} \quad \underline{1998} \quad \underline{1999}$

0,529

0,521

0,167

0,521

0,628

0,626

0,336

0,358

0,125

0,641

0,293

0,296

0,339

0,219

0,046

0,070

0,442

0,424

0,342

0,321

0,281

0,434

0,497

0,448

0,234

0,319

0,335

0,309

0,442

0,504

0,447

0,275

0,335

0,314

0,153

0,148

0,498

0,491

0,056

0,433

0,400

0,400

0,648

0,080

0,423

0,417

0,408

0,653

0,483

0,482

0,427

0,423

0,576

0,347

0,343

0,272

0,283

0,359

0,344

$0,211 \quad 0,220$

0,175

0,184

0,229

0,192

0,225

0,219

0,222

0,246

0,206

0,252

0,191

0,257

0,185

0,542

0,520

0,498

0,514

0,530

0,491

0,617
0,602 $\underline{2003}$

0,526

0,254

0,488

0,665

0,423

0,146

0,563

0,352

0,248

0,296

0,254

0,138

0,212

0,330

0,350

0,293

0,459

0,501

0,486

0,319

0,331

0,298

0,492

0,139

0,496

0,437

0,474

0,686

0,467

0,438

0,562

0,407

0,224

0,314

0,635

0,613

0,615

0,452

0,435

0,550 


$\begin{array}{lllllllll}\text { Senegal } & 0,438 & 0,428 & 0,419 & 0,432 & 0,446 & 0,464 & 0,481 & 0,458 \\ \text { Serra Leoa } & 0,182 & 0,177 & 0,172 & 0,172 & 0,173 & 0,213 & 0,253 & 0,263 \\ \text { Somália } & 0,035 & 0,042 & 0,049 & 0,052 & 0,055 & 0,076 & 0,098 & 0,042 \\ \text { Suazilândia } & 0,400 & 0,405 & 0,410 & 0,406 & 0,403 & 0,409 & 0,416 & 0,398 \\ \text { Sudão } & 0,149 & 0,153 & 0,157 & 0,163 & 0,168 & 0,191 & 0,214 & 0,177 \\ \text { Tanzânia } & 0,387 & 0,404 & 0,421 & 0,407 & 0,393 & 0,409 & 0,424 & 0,398 \\ \text { Togo } & 0,363 & 0,350 & 0,337 & 0,340 & 0,343 & 0,348 & 0,353 & 0,316 \\ \text { Uganda } & 0,302 & 0,326 & 0,350 & 0,341 & 0,332 & 0,331 & 0,329 & 0,334 \\ \text { Zâmbia } & 0,371 & 0,393 & 0,414 & 0,409 & 0,403 & 0,400 & 0,397 & 0,425 \\ \text { Zimbábue } & 0,395 & 0,382 & 0,370 & 0,317 & 0,265 & 0,246 & 0,228 & 0,249\end{array}$

País

África do

Sul

Angola

Benim

Botsuana

Burquina

Faso

Burundi

Cabo Verde

Camarões

Chade

Comores

Congo

Congo, RD

Costa do

Marfim

Djibuti

Eritreia

Etiópia

Gabão

Gâmbia

Gana

Guiné

Guiné

Equatoria

Guiné-

Bissau

Lesoto

Libéria

Madagascar

Maláui

Mali

Maurício

Mauritânia

\section{$\underline{2004}$}

0,542

0,248

0,454

0,644

0,420

0,138

0,585

0,347

0,236

0,315

0,273

0,131

0,177

0,384

0,345

0,313

0,438

0,461

0,480

0,288

0,299

0,296

0,489

0,187

0,468

0,450

0,479

0,675

0,417
0,538

0,266

0,449

0,655

0,421

0,236

0,558

0,351

0,220

0,296

0,240

0,145

0,157

0,332

0,327

0,273

0,434

0,453

0,492

0,261

0,277

0,285

0,479

0,227

0,450

0,444

0,457

0,675

0,419 $\underline{2006}$

0,553

0,286

0,459

0,638

0,432

0,270

0,609

0,345

0,183

0,301

0,269

0,131

0,198

0,370

0,281

0,307

0,407

0,432

0,508

0,190

0,312

0,308

0,450

0,276

0,445

0,437

0,461

0,652

0,415 $\underline{2007}$

0,551

0,278

0,451

0,646

0,444

0,257

0,620

0,345

0,169

0,244

0,279

0,128

0,194

0,392

0,264

0,317

0,416

0,449

0,501

0,159

0,453

0,249

0,593

0,338

0,160

0,238

0,293

0,150

0,201

0,422

0,286

0,317

0,419

0,434

0,493

0,179

0,317

0,319

0,306

0,288

0,424

0,442

0,266

0,247

0,447

0,395

0,454

0,451

0,453

0,440

0,663

0,674

0,382

0,319 $\underline{2009}$

0,530

0,328

0,443

0,638

0,449

0,269

0,591

0,339

0,193

0,255

0,320

0,145

0,258

0,430

0,281

0,307

0,421

0,438

0,495

0,189

0,532

0,327

0,430

0,639

0,441

0,241

0,584

0,323

0,204

0,280

0,317

0,128

0,229

0,404

0,265

0,314

0,433

0,428

0,495

0,213

0,328

0,318

0,297

0,488

0,297

0,491

0,317

0,274

0,350

0,310

0,464

0,466

0,401

0,419

0,653

0,658

0,306 $\underline{2011}$

0,538

0,316

0,437

0,646

0,400

0,235

0,590

0,328

0,226

0,284

0,319

0,132

0,246

0,395

0,269

0,323

0,442

0,426

0,504

0,233

0,319

0,294

0,487

0,325

0,326

0,454

0,369

0,679

0,304 


$\begin{array}{lrrrrrrrr}\text { Moçambique } & 0,421 & 0,432 & 0,455 & 0,448 & 0,449 & 0,464 & 0,453 & 0,440 \\ \text { Namíbia } & 0,550 & 0,538 & 0,570 & 0,584 & 0,617 & 0,583 & 0,574 & 0,576 \\ \text { Níger } & 0,371 & 0,362 & 0,389 & 0,373 & 0,359 & 0,344 & 0,343 & 0,372 \\ \text { Nigéria } & 0,229 & 0,240 & 0,228 & 0,225 & 0,241 & 0,212 & 0,199 & 0,217 \\ \text { Quênia } & 0,336 & 0,311 & 0,327 & 0,317 & 0,301 & 0,294 & 0,320 & 0,316 \\ \text { Rep. Centro- } & & & & & & & & \\ \text { Africana } & 0,193 & 0,200 & 0,184 & 0,180 & 0,189 & 0,192 & 0,187 & 0,211 \\ \text { Ruanda } & 0,331 & 0,315 & 0,391 & 0,428 & 0,439 & 0,424 & 0,463 & 0,475 \\ \text { São Tomé e } & & & & & & & & \\ \text { Príncipe } & 0,472 & 0,453 & 0,430 & 0,451 & 0,437 & 0,416 & 0,407 & 0,404 \\ \text { Seicheles } & 0,556 & 0,571 & 0,563 & 0,571 & 0,573 & 0,552 & 0,573 & 0,580 \\ \text { Senegal } & 0,486 & 0,468 & 0,443 & 0,436 & 0,462 & 0,429 & 0,408 & 0,417 \\ \text { Serra Leoa } & 0,319 & 0,302 & 0,336 & 0,352 & 0,345 & 0,338 & 0,340 & 0,351 \\ \text { Somália } & 0,011 & 0,025 & -0,010 & -0,047 & -0,062 & -0,039 & -0,020 & -0,006 \\ \text { Suazilândia } & 0,376 & 0,345 & 0,379 & 0,394 & 0,403 & 0,410 & 0,430 & 0,391 \\ \text { Sudão } & 0,214 & 0,168 & 0,196 & 0,179 & 0,156 & 0,156 & 0,145 & 0,191 \\ \text { Tanzânia } & 0,405 & 0,419 & 0,426 & 0,428 & 0,431 & 0,433 & 0,427 & 0,418 \\ \text { Togo } & 0,296 & 0,230 & 0,293 & 0,315 & 0,338 & 0,336 & 0,333 & 0,341 \\ \text { Uganda } & 0,348 & 0,331 & 0,368 & 0,383 & 0,376 & 0,365 & 0,372 & 0,377 \\ \text { Zâmbia } & 0,421 & 0,404 & 0,431 & 0,437 & 0,453 & 0,451 & 0,442 & 0,458 \\ \text { Zimbábue } & 0,235 & 0,214 & 0,237 & 0,222 & 0,202 & 0,199 & 0,205 & 0,227 \\ & & & & & & & & \end{array}$




\section{Apêndice III - Dados sobre Desenvolvimento}

\begin{tabular}{|c|c|c|c|c|c|c|}
\hline$\frac{\text { País }}{\text { África do }}$ & $\underline{1990}$ & $\underline{1991}$ & $\underline{1992}$ & $\underline{1993}$ & $\underline{1994}$ & $\underline{1995}$ \\
\hline Sul & 0,568 & 0,573 & 0,576 & 0,585 & 0,591 & 0,596 \\
\hline Angola & 0,279 & 0,263 & 0,257 & 0,257 & 0,264 & 0,251 \\
\hline Benim & 0,263 & 0,262 & 0,266 & 0,273 & 0,277 & 0,280 \\
\hline Botsuana & 0,418 & 0,435 & 0,437 & 0,444 & 0,438 & 0,450 \\
\hline \multicolumn{7}{|l|}{ Burquina } \\
\hline Faso & 0,259 & 0,265 & 0,270 & 0,270 & 0,269 & 0,270 \\
\hline Burundi & 0,230 & 0,246 & 0,241 & 0,239 & 0,244 & 0,252 \\
\hline Cabo Verde & 0,393 & 0,405 & 0,416 & 0,428 & 0,426 & 0,435 \\
\hline Camarões & 0,370 & 0,374 & 0,376 & 0,381 & 0,380 & 0,383 \\
\hline Chade & 0,245 & 0,233 & 0,240 & 0,226 & 0,228 & 0,234 \\
\hline Comores & 0,267 & 0,282 & 0,282 & 0,284 & 0,281 & 0,280 \\
\hline Congo & 0,392 & 0,384 & 0,387 & 0,380 & 0,364 & 0,366 \\
\hline Congo, RD & 0,321 & 0,314 & 0,306 & 0,308 & 0,301 & 0,302 \\
\hline \multicolumn{7}{|l|}{ Costa do } \\
\hline Marfim & 0,372 & 0,383 & 0,384 & 0,383 & 0,384 & 0,392 \\
\hline Djibuti & 0,246 & 0,220 & 0,219 & 0,221 & 0,227 & 0,230 \\
\hline Gabão & 0,510 & 0,518 & 0,520 & 0,504 & 0,501 & 0,501 \\
\hline Gâmbia & 0,241 & 0,248 & 0,251 & 0,268 & 0,265 & 0,266 \\
\hline Gana & 0,298 & 0,284 & 0,313 & 0,320 & 0,327 & 0,332 \\
\hline Guiné & 0,325 & 0,328 & 0,332 & 0,334 & 0,329 & 0,328 \\
\hline \multicolumn{7}{|l|}{ Guiné } \\
\hline $\begin{array}{l}\text { Equatorial } \\
\text { Guiné- }\end{array}$ & 0,290 & 0,292 & 0,299 & 0,304 & 0,300 & 0,305 \\
\hline Bissau & 0,238 & 0,232 & 0,236 & 0,245 & 0,234 & 0,232 \\
\hline Lesoto & 0,360 & 0,365 & 0,369 & 0,371 & 0,372 & 0,373 \\
\hline Madagascar & 0,332 & 0,339 & 0,345 & 0,346 & 0,348 & 0,352 \\
\hline Maláui & 0,288 & 0,269 & 0,264 & 0,266 & 0,271 & 0,287 \\
\hline Mali & 0,267 & 0,263 & 0,262 & 0,266 & 0,266 & 0,270 \\
\hline Maurício & 0,475 & 0,486 & 0,501 & 0,508 & 0,524 & 0,546 \\
\hline Mauritânia & 0,295 & 0,298 & 0,325 & 0,331 & 0,337 & 0,342 \\
\hline Moçambique & 0,218 & 0,207 & 0,206 & 0,209 & 0,211 & 0,210 \\
\hline Namíbia & 0,377 & 0,379 & 0,385 & 0,389 & 0,396 & 0,398 \\
\hline Níger & 0,235 & 0,216 & 0,211 & 0,215 & 0,226 & 0,231 \\
\hline Nigéria & 0,313 & 0,321 & 0,331 & 0,331 & 0,329 & 0,332 \\
\hline Quênia & 0,415 & 0,404 & 0,402 & 0,402 & 0,396 & 0,399 \\
\hline \multicolumn{7}{|l|}{ Rep. Centro- } \\
\hline Africana & 0,293 & 0,289 & 0,286 & 0,299 & 0,301 & 0,307 \\
\hline Ruanda & 0,238 & 0,238 & 0,239 & 0,229 & 0,223 & 0,220 \\
\hline Seicheles & 0,600 & 0,604 & 0,629 & 0,640 & 0,646 & 0,646 \\
\hline Senegal & 0,284 & 0,286 & 0,292 & 0,291 & 0,288 & 0,288 \\
\hline Serra Leoa & 0,276 & 0,268 & 0,270 & 0,275 & 0,274 & 0,277 \\
\hline Suazilândia & 0,413 & 0,422 & 0,428 & 0,425 & 0,421 & 0,423 \\
\hline Sudão & 0,329 & 0,323 & 0,326 & 0,333 & 0,338 & 0,344 \\
\hline
\end{tabular}




$\begin{array}{lllllll}\text { Tanzânia } & 0,326 & 0,335 & 0,333 & 0,326 & 0,324 & 0,324 \\ \text { Togo } & 0,311 & 0,306 & 0,306 & 0,305 & 0,316 & 0,326 \\ \text { Uganda } & 0,248 & 0,258 & 0,258 & 0,262 & 0,256 & 0,259 \\ \text { Zâmbia } & 0,272 & 0,273 & 0,270 & 0,273 & 0,277 & 0,278 \\ \text { Zimbábue } & 0,446 & 0,410 & 0,399 & 0,394 & 0,392 & 0,391\end{array}$

País

África do

Sul

Angola

Benim

Botsuana

Burquina

Faso

Burundi

Cabo Verde

Camarões

Chade

Comores

Congo

Congo, RD

Costa do

Marfim

Djibuti

Gabão

Gâmbia

Gana

Guiné

Guiné

Equatorial

Guiné-

Bissau

Lesoto

Madagascar

Maláui

Mali

Maurício

Mauritânia

Moçambique

Namíbia

Níger

Nigéria

Quênia

Rep. Centro-

Africana

Ruanda $\underline{1996}$

0,599

0,256

0,284

0,450

0,266

0,243

0,442

0,383

0,241

0,275

0,369

0,304

0,393

0,232

0,518

0,264

0,338

0,327

0,313

0,335

0,222

0,373

0,223

0,363

0,358

0,282

0,273

0,556

0,349

0,217

0,402

0,234

0,335

0,400

0,367

0,289

0,276

0,558

0,351

0,223

0,401

0,245

0,334

0,408

0,296

0,300 $\underline{1998}$

0,593

0,251

0,291

0,459

0,259

0,235

0,461

0,387

0,251

0,260

0,384

0,303

0,398

0,398

0,515

0,276

0,348

0,331

0,254

0,215

0,474

0,393

0,249

0,259

0,382

0,300

0,404

0,262

0,502

0,283

0,356

0,336

0,334

0,345

0,221

0,225

0,371

0,372

0,373

0,292

0,279

0,379

0,297

0,284

0,560

0,565

0,358

0,361

0,229

0,404

0,238

0,410

0,242

0,247

0,334

0,337

0,409

0,403

0,407

0,270

0,506

0,311

0,361

0,335

0,343

0,230

0,383

0,384

0,292

0,302

0,573

0,372

0,240

0,434

0,256

0,328

0,413

0,301

0,297

0,298

0,239

0,251

0,227
0,407

0,279

0,512

0,315

0,377

0,331

0,347

0,234

0,383

0,386

0,295

0,308

0,578

0,375

0,241

0,441

0,248

0,332

0,413

0,406

0,288

0,515

0,309

0,400

0,341

0,361

0,364

0,224

0,221

0,300

0,236

0,247

0,379

0,381

0,371

0,375

0,294

0,300

0,314

0,319

0,590

0,605

0,378

0,377

0,251

0,257

0,437

0,435

0,257

0,269

0,335

0,352

$0,413 \quad 0,419$

0,262

0,304

0,304

$0,270 \quad 0,273$ 


$\begin{array}{lllllllll}\text { Seicheles } & 0,654 & 0,652 & 0,653 & 0,658 & 0,658 & 0,659 & 0,645 & 0,664 \\ \text { Senegal } & 0,292 & 0,301 & 0,306 & 0,316 & 0,324 & 0,332 & 0,342 & 0,357 \\ \text { Serra Leoa } & 0,259 & 0,252 & 0,249 & 0,241 & 0,244 & 0,238 & 0,243 & 0,248 \\ \text { Suazilândia } & 0,423 & 0,421 & 0,418 & 0,418 & 0,415 & 0,413 & 0,407 & 0,404 \\ \text { Sudão } & 0,345 & 0,345 & 0,345 & 0,341 & 0,311 & 0,325 & 0,330 & 0,337 \\ \text { Tanzânia } & 0,337 & 0,339 & 0,343 & 0,348 & 0,355 & 0,364 & 0,367 & 0,373 \\ \text { Togo } & 0,330 & 0,335 & 0,340 & 0,345 & 0,351 & 0,359 & 0,366 & 0,376 \\ \text { Uganda } & 0,260 & 0,267 & 0,282 & 0,292 & 0,308 & 0,330 & 0,340 & 0,345 \\ \text { Zâmbia } & 0,285 & 0,287 & 0,287 & 0,295 & 0,295 & 0,295 & 0,296 & 0,298 \\ \text { Zimbábue } & 0,392 & 0,392 & 0,387 & 0,386 & 0,388 & 0,383 & 0,382 & 0,400\end{array}$

\begin{tabular}{|c|c|c|c|c|c|c|c|c|}
\hline País & $\underline{2004}$ & $\underline{2005}$ & $\underline{2006}$ & $\underline{2007}$ & $\underline{2008}$ & $\underline{2009}$ & $\underline{2010}$ & $\underline{2011}$ \\
\hline \multicolumn{9}{|l|}{ África do } \\
\hline Sul & 0,602 & 0,629 & 0,646 & 0,657 & 0,659 & 0,660 & 0,675 & 0,701 \\
\hline Angola & 0,285 & 0,289 & 0,312 & 0,335 & 0,357 & 0,374 & 0,382 & 0,388 \\
\hline Benim & 0,350 & 0,360 & 0,361 & 0,373 & 0,380 & 0,399 & 0,400 & 0,403 \\
\hline Botsuana & 0,500 & 0,538 & 0,556 & 0,572 & 0,578 & 0,566 & 0,582 & 0,608 \\
\hline \multicolumn{9}{|l|}{ Burquina } \\
\hline Faso & 0,273 & 0,282 & 0,289 & 0,292 & 0,300 & 0,300 & 0,319 & 0,322 \\
\hline Burundi & 0,241 & 0,239 & 0,241 & 0,251 & 0,252 & 0,257 & 0,262 & 0,269 \\
\hline Cabo Verde & 0,516 & 0,529 & 0,549 & 0,562 & 0,577 & 0,580 & 0,581 & 0,588 \\
\hline Camarões & 0,416 & 0,421 & 0,428 & 0,435 & 0,442 & 0,447 & 0,462 & 0,469 \\
\hline Chade & 0,235 & 0,234 & 0,234 & 0,236 & 0,243 & 0,240 & 0,247 & 0,227 \\
\hline Comores & 0,318 & 0,315 & 0,322 & 0,325 & 0,326 & 0,330 & 0,336 & 0,346 \\
\hline Congo & 0,394 & 0,401 & 0,409 & 0,414 & 0,426 & 0,426 & 0,443 & 0,446 \\
\hline Congo, RD & 0,308 & 0,307 & 0,305 & 0,297 & 0,313 & 0,316 & 0,322 & 0,324 \\
\hline \multicolumn{9}{|l|}{ Costa do } \\
\hline Marfim & 0,418 & 0,427 & 0,437 & 0,440 & 0,436 & 0,441 & 0,442 & 0,439 \\
\hline Djibuti & 0,308 & 0,316 & 0,318 & 0,323 & 0,332 & 0,345 & 0,364 & 0,382 \\
\hline Gabão & 0,533 & 0,559 & 0,574 & 0,594 & 0,633 & 0,643 & 0,652 & 0,654 \\
\hline Gâmbia & 0,288 & 0,294 & 0,305 & 0,313 & 0,322 & 0,312 & 0,309 & 0,307 \\
\hline Gana & 0,429 & 0,442 & 0,451 & 0,465 & 0,480 & 0,487 & 0,497 & 0,500 \\
\hline Guiné & 0,356 & 0,363 & 0,367 & 0,372 & 0,374 & 0,375 & 0,379 & 0,385 \\
\hline \multicolumn{9}{|l|}{ Guiné } \\
\hline $\begin{array}{l}\text { Equatorial } \\
\text { Guiné- }\end{array}$ & 0,382 & 0,464 & 0,582 & 0,645 & 0,644 & 0,705 & 0,659 & 0,662 \\
\hline Bissau & 0,250 & 0,256 & 0,263 & 0,269 & 0,276 & 0,292 & 0,296 & 0,301 \\
\hline Lesoto & 0,384 & 0,392 & 0,397 & 0,398 & 0,404 & 0,410 & 0,416 & 0,428 \\
\hline Madagascar & 0,381 & 0,381 & 0,386 & 0,390 & 0,395 & 0,393 & 0,392 & 0,392 \\
\hline Maláui & 0,305 & 0,308 & 0,315 & 0,324 & 0,332 & 0,338 & 0,344 & 0,356 \\
\hline Mali & 0,323 & 0,325 & 0,330 & 0,338 & 0,343 & 0,349 & 0,352 & 0,358 \\
\hline Maurício & 0,628 & 0,645 & 0,650 & 0,664 & 0,683 & 0,696 & 0,709 & 0,726 \\
\hline Mauritânia & 0,382 & 0,378 & 0,366 & 0,361 & 0,365 & 0,365 & 0,364 & 0,371 \\
\hline Moçambique & 0,264 & 0,275 & 0,285 & 0,300 & 0,306 & 0,313 & 0,312 & 0,318 \\
\hline Namíbia & 0,436 & 0,436 & 0,434 & 0,433 & 0,434 & 0,436 & 0,439 & 0,444 \\
\hline Níger & 0,277 & 0,287 & 0,301 & 0,317 & 0,328 & 0,333 & 0,351 & 0,361 \\
\hline
\end{tabular}




$\begin{array}{lcccccccc}\text { Nigéria } & 0,362 & 0,375 & 0,378 & 0,380 & 0,390 & 0,396 & 0,405 & 0,422 \\ \text { Quênia } & 0,429 & 0,432 & 0,438 & 0,445 & 0,456 & 0,460 & 0,464 & 0,466 \\ \begin{array}{l}\text { Rep. Centro- } \\ \text { Africana }\end{array} & 0,306 & 0,311 & 0,318 & 0,325 & 0,332 & 0,336 & 0,341 & 0,344 \\ \text { Ruanda } & 0,279 & 0,289 & 0,309 & 0,324 & 0,337 & 0,351 & 0,364 & 0,383 \\ \text { Seicheles } & 0,688 & 0,727 & 0,761 & 0,767 & 0,746 & 0,727 & 0,728 & 0,746 \\ \text { Senegal } & 0,371 & 0,384 & 0,392 & 0,402 & 0,408 & 0,412 & 0,413 & 0,419 \\ \text { Serra Leoa } & 0,247 & 0,251 & 0,260 & 0,254 & 0,258 & 0,260 & 0,261 & 0,263 \\ \text { Suazilândia } & 0,416 & 0,438 & 0,448 & 0,447 & 0,436 & 0,433 & 0,445 & 0,458 \\ \text { Sudão } & 0,342 & 0,346 & 0,353 & 0,360 & 0,342 & 0,344 & 0,347 & 0,355 \\ \text { Tanzânia } & 0,380 & 0,387 & 0,391 & 0,399 & 0,404 & 0,409 & 0,413 & 0,421 \\ \text { Togo } & 0,381 & 0,385 & 0,388 & 0,387 & 0,394 & 0,403 & 0,408 & 0,421 \\ \text { Uganda } & 0,355 & 0,355 & 0,364 & 0,370 & 0,375 & 0,378 & 0,385 & 0,388 \\ \text { Zâmbia } & 0,296 & 0,298 & 0,269 & 0,273 & 0,285 & 0,286 & 0,293 & 0,296 \\ \text { Zimbábue } & 0,412 & 0,411 & 0,412 & 0,413 & 0,412 & 0,412 & 0,417 & 0,424\end{array}$




\section{Apêndice IV - Diversidade Étnica na África Subsaariana}

Ver definições e fontes no apêndice 1, item "Etnias".

\begin{tabular}{|c|c|c|c|}
\hline País & $\underline{\text { EPR }}$ & PREG & $\underline{\text { LEGITH }}$ \\
\hline $\begin{array}{l}\text { África do } \\
\quad \text { Sul }\end{array}$ & 15 & 0,49 & \\
\hline Angola & 5 & 0,65 & 0,5250 \\
\hline Benim & 4 & 0,30 & 0,6746 \\
\hline Botsuana & 10 & 0,00 & 0,9035 \\
\hline $\begin{array}{c}\text { Burquina } \\
\text { Faso }\end{array}$ & 1 & 0,00 & 0,5735 \\
\hline Burundi & 2 & 0,26 & 0,9800 \\
\hline Cabo Verde & & & 1,0000 \\
\hline Camarões & 6 & 0,71 & 0,8565 \\
\hline Chade & 7 & 0,66 & 0,4793 \\
\hline Comores & & & 0,0000 \\
\hline Congo & 9 & 0,19 & 0,2474 \\
\hline Congo, DR & 13 & 0,80 & 0,3734 \\
\hline $\begin{array}{c}\text { Costa do } \\
\text { Marfim }\end{array}$ & 5 & 0,49 & 0,7616 \\
\hline Djibuti & 2 & & 0,1137 \\
\hline Eritreia & 5 & & \\
\hline Etiópia & 11 & 0,57 & 0,9493 \\
\hline Gabão & 6 & 0,21 & 0,3262 \\
\hline Gâmbia & 5 & 0,37 & 0,8290 \\
\hline Gana & 5 & 0,44 & 0,6609 \\
\hline Guiné & 3 & 0,48 & 0,0867 \\
\hline $\begin{array}{c}\text { Guiné } \\
\text { Equatorial }\end{array}$ & & 0,19 & 0,1500 \\
\hline $\begin{array}{l}\text { Guiné- } \\
\text { Bissau }\end{array}$ & 5 & 0,05 & 0,5575 \\
\hline Lesoto & 1 & 0,00 & 0,9900 \\
\hline Libéria & 8 & 0,62 & 0,5635 \\
\hline Madagascar & 2 & 0,00 & 1,0000 \\
\hline Maláui & 3 & 0,55 & 0,3400 \\
\hline Mali & 3 & 0,13 & 0,1346 \\
\hline Maurício & 9 & 0,60 & 1,0000 \\
\hline Mauritânia & 4 & & 0,0352 \\
\hline Moçambique & 3 & 0,36 & 0,8048 \\
\hline Namíbia & 12 & 0,55 & 0,3810 \\
\hline Níger & 6 & 0,51 & 0,2906 \\
\hline
\end{tabular}




$\begin{array}{lrrr}\text { Nigéria } & 6 & 0,66 & 0,4888 \\ \text { Quênia } & 8 & 0,57 & 0,6428 \\ \text { República } & & & \\ \text { Centro- } & 7 & 0,23 & 0,1865 \\ \text { Africana } & & & \\ \text { Ruanda } & 2 & 0,26 & 0,9900 \\ \text { São Tomé e } & & & 1,0000 \\ \text { Príncipe } & & & \\ \text { Seicheles } & & & 1,0000 \\ \text { Senegal } & 5 & 0,14 & 0,2022 \\ \text { Serra Leoa } & 6 & 0,56 & 0,6363 \\ \text { Somália } & 1 & 0,00 & 0,0250 \\ \text { Suazilândia } & 1 & 0,00 & 1,0000 \\ \text { Sudão } & 16 & 0,41 & 0,4159 \\ \text { Sudão do } & 10 & & \\ \text { Sul } & & & \\ \text { Tanzânia } & 6 & 0,59 & 0,7406 \\ \text { Togo } & 2 & 0,49 & 0,5912 \\ \text { Uganda } & 15 & 0,63 & 0,6341 \\ \text { Zâmbia } & 7 & 0,71 & 0,4428 \\ \text { Zimbábue } & 8 & 0,41 & 0,7500\end{array}$




\section{Apêndice V - Pesquisa de opinião: Obediência ao governo}

Pesquisa de opinião do Afrobarometer (2015). Aos entrevistados, foram apresentadas duas afirmações: "é importante obedecer ao governo no poder, independentemente de para quem você votou" e "não é necessário obedecer às leis de um governo para o qual você não votou". Eles deviam dizer se concordavam fortemente ou concordavam com alguma das frases ou se não concordavam com nenhuma delas. Na tabela, a letra A representa as respostas que afirmaram "concordar fortemente" com a primeira frase e a letra $\mathrm{B}$, as respostas que afirmaram apenas "concordar" com ela.

\begin{tabular}{|c|c|c|c|c|c|c|c|c|c|}
\hline \multirow{2}{*}{ País } & \multicolumn{3}{|c|}{$2005 / 2006$} & \multicolumn{3}{|c|}{$2011 / 2013$} & \multicolumn{3}{|c|}{$2014 / 2015$} \\
\hline & $A$ & B & Soma (\%) & $A$ & B & Soma (\%) & $A$ & B & Soma (\%) \\
\hline África do Sul & 38,3 & 41,6 & 79,9 & 39,5 & 37,6 & 77,1 & 43,8 & 35,4 & 79,2 \\
\hline Benim & 83,4 & 13,0 & 96,4 & 66,2 & 27,3 & 93,5 & 49,8 & 44,4 & 94,2 \\
\hline Botsuana & 52,4 & 37,1 & 89,5 & 60,8 & 31,4 & 92,2 & 53,1 & 31,4 & 84,5 \\
\hline Burquina Faso & & & & 48,3 & 38,5 & 86,8 & 52,3 & 37,1 & 89,4 \\
\hline Burundi & & & & 50,9 & 34,1 & 85,0 & 51,7 & 39,4 & 91,1 \\
\hline Cabo Verde & 60,7 & 25,4 & 86,1 & 42,9 & 42,1 & 85,0 & 36,8 & 52,9 & 89,7 \\
\hline Camarões & & & & 54,5 & 37,1 & 91,6 & 40,7 & 41,7 & 82,4 \\
\hline Costa do Marfim & & & & 36,5 & 58,9 & 95,4 & 40,9 & 52,6 & 93,5 \\
\hline Gabão & & & & & & & 46,8 & 40,5 & 87,3 \\
\hline Gana & 66,5 & 28,8 & 95,3 & 72,7 & 20,5 & 93,2 & 70,8 & 16,1 & 86,9 \\
\hline Guiné & & & & 48,7 & 39,7 & 88,4 & 59,1 & 33,0 & 92,1 \\
\hline Lesoto & 75,2 & 16,1 & 91,3 & 75,4 & 13,8 & 89,2 & 74,8 & 12,3 & 87,1 \\
\hline Libéria & & & & & & & 55,7 & 29,6 & 85,3 \\
\hline Madagascar & 31,2 & 58,5 & 89,7 & 33,5 & 56,2 & 89,7 & 40,0 & 48,8 & 88,8 \\
\hline Maláui & 54,3 & 40,1 & 94,4 & 73,3 & 14,9 & 88,2 & 83,5 & 4,9 & 88,4 \\
\hline Mali & & & & 52,3 & 35,5 & 87,8 & 71,6 & 18,5 & 90,1 \\
\hline Maurício & & & & 38,0 & 52,2 & 90,2 & 23,3 & 66,7 & 90,0 \\
\hline Moçambique & 53,8 & 27,1 & 80,9 & 51,7 & 25,5 & 77,2 & 36,0 & 29,1 & 65,1 \\
\hline
\end{tabular}




\begin{tabular}{|c|c|c|c|c|c|c|}
\hline Namíbia & $39,2 \quad 28,7$ & 67,9 & $33,4 \quad 36,4$ & 69,8 & $41,841,7$ & 83,5 \\
\hline Níger & & & & & $58,5 \quad 29,0$ & 87,5 \\
\hline Nigéria & $44,8 \quad 36,0$ & 80,8 & $43,3 \quad 38,8$ & 82,1 & $46,3 \quad 36,1$ & 82,4 \\
\hline Quênia & $63,230,0$ & 93,2 & $67,5 \quad 23,8$ & 91,3 & $67,6 \quad 24,4$ & 92,0 \\
\hline Senegal & $41,3 \quad 46,9$ & 88,2 & $50,934,1$ & 85,0 & $72,7 \quad 21,8$ & 94,5 \\
\hline Serra Leoa & & & $46,6 \quad 33,6$ & 80,2 & $68,8 \quad 19,6$ & 88,4 \\
\hline Suazilândia & & & $46,2 \quad 42,1$ & 88,3 & $45,2 \quad 46,0$ & 91,2 \\
\hline Sudão & & & $37,7 \quad 32,1$ & 69,8 & $30,3 \quad 44,4$ & 74,7 \\
\hline Tanzânia & $69,1 \quad 22,3$ & 91,4 & $65,2 \quad 27,2$ & 92,4 & $50,2 \quad 38,3$ & 88,5 \\
\hline Togo & & & $55,936,1$ & 92,0 & $53,8 \quad 38,3$ & 92,1 \\
\hline Uganda & $57,9 \quad 32,6$ & 90,5 & $65,7 \quad 21,8$ & 87,5 & $65,7 \quad 25,2$ & 90,9 \\
\hline Zâmbia & $42,4 \quad 44,1$ & 86,5 & $73,2 \quad 22,4$ & 95,6 & $62,1 \quad 26,2$ & 88,3 \\
\hline Zimbábue & $46,2 \quad 37,5$ & 83,7 & $52,5 \quad 35,4$ & 87,9 & $61,4 \quad 28,4$ & 89,8 \\
\hline Total & $54,1 \quad 32,5$ & 86,6 & $55,1 \quad 32,1$ & 87,2 & $54,1 \quad 32,7$ & 36,8 \\
\hline
\end{tabular}




\section{Apêndice VI - Responsabilidade primária de elementos da governança}

Pesquisa de opinião do Afrobarometer (2009b; 2009c; 2009d). Os entrevistados foram perguntados "Quem você acha que tem a responsabilidade primária na gestão das seguintes tarefas. É o governo central (GC), o governo local (GL), os líderes tradicionais (LT) ou os membros da comunidade (MC)". As tarefes selecionadas nesta pesquisa foram a alocação de terras, a coleta do imposto de renda e a resolução de disputas locais. As células em branco correspondem aos países onde a pesquisa não foi realizada. As células pintadas de verde são o valor ou a soma dos valores mais altos superior ou igual a $50 \%$. Elas indicam o(s) níveis a que a metade ou mais da população atribui a responsabilidade desta governança (central ou local). As células com contorno vermelho representam o valor ou a soma dos valores em GC e/ou GL e LT e/ou MC superiores ou iguais a 50\%. Elas indicam se metade ou mais da população atribui essa responsabilidade ao governo (ou seja, ao aparato estatal) ou a agentes não-estatais.

\begin{tabular}{|c|c|c|c|c|c|c|c|c|c|c|c|c|}
\hline \multirow[t]{2}{*}{ País } & \multicolumn{4}{|c|}{$\begin{array}{c}\text { Alocação de Terras } \\
(\%)\end{array}$} & \multicolumn{4}{|c|}{$\begin{array}{c}\text { Imposto de Renda } \\
(\%)\end{array}$} & \multicolumn{4}{|c|}{ Disputas Locais (\%) } \\
\hline & GC & GL & $\mathrm{LT}$ & $\mathrm{MC}$ & GC & GL & LT & $\mathrm{MC}$ & $\mathrm{GC}$ & GL & LT & $\mathrm{MC}$ \\
\hline África do Sul & 39,1 & 29,5 & 17,7 & 4,4 & 56,5 & 23,9 & 3,6 & 4 & 19 & 48,5 & 12,9 & 11,2 \\
\hline Benim & 33,4 & 40 & 16,6 & 8,1 & 70,5 & 19,1 & 1,3 & 2,7 & 27,8 & 52,4 & 12,7 & 5,9 \\
\hline Botsuana & 38 & 34,5 & 24,5 & 1,7 & 72,9 & 13,2 & 2,9 & 0,8 & 10,5 & 7,7 & 75,3 & 5,7 \\
\hline $\begin{array}{l}\text { Burquina } \\
\text { Faso }\end{array}$ & 25,5 & 34,8 & 27,7 & 5 & 57,3 & 22,5 & 2,5 & 4,9 & 29,3 & 33 & 24,7 & 6,3 \\
\hline Cabo Verde & 17,8 & 71,5 & - & 2,2 & 52 & 38,5 & - & 1,4 & 30,6 & 46,4 & - & 13 \\
\hline Gana & 8,3 & 16,7 & 68,2 & 4,6 & 38,8 & 49,6 & 4,5 & 2,9 & 11,8 & 21,2 & 58,5 & 5,8 \\
\hline Lesoto & 8 & 48 & 41,4 & 1,4 & 82,8 & 7,6 & 2,8 & 1,2 & 8,4 & 11,3 & 75,6 & 3,6 \\
\hline Libéria & 48,7 & 29,3 & 14,6 & 6,5 & 80,8 & 13,6 & 2,4 & 1,6 & 23,2 & 32,2 & 29,2 & 15 \\
\hline Madagascar & 22,3 & 50,3 & 1,5 & 15,7 & 17,9 & 67,7 & 0,4 & 4,7 & 3,8 & 55,6 & 7,2 & 29 \\
\hline Maláui & 23 & 7,6 & 61,2 & 4,5 & 67,8 & 17,8 & 3,4 & 3,7 & 30,2 & 5,1 & 55 & 6,6 \\
\hline Mali & 22,1 & 34 & 36,3 & 5,3 & 39,1 & 41 & 11,4 & 6,7 & 18,3 & 24,1 & 45,3 & 10,8 \\
\hline Moçambique & 15,7 & 54,1 & - & 21,6 & 28,1 & 49,5 & - & 11 & 9,7 & 48,6 & . & 33,6 \\
\hline Namíbia & 30,7 & 41,9 & 23,3 & 2,5 & 64,8 & 22,9 & 5,4 & 1,6 & 26,8 & 37,9 & 22,4 & 8,3 \\
\hline Nigéria & 18,3 & 28,9 & 20,3 & 3,9 & 21,8 & 35 & 3,9 & 1,9 & 10,4 & 33,6 & 28,1 & 3,9 \\
\hline Quênia & 53 & 20,1 & 19,5 & 5,4 & 52,6 & 40,9 & 2,6 & 1 & 17,5 & 14,8 & 52,7 & 14 \\
\hline Senegal & 23,5 & 50,1 & 14,8 & 4,6 & 45 & 31,5 & 8,3 & 1,8 & 13,8 & 33,3 & 32,1 & 16,4 \\
\hline Tanzânia & 44,1 & 45,3 & 1,3 & 7,5 & 46,4 & 45,5 & 0,4 & 3,8 & 24,3 & 54,7 & 4,3 & 15,2 \\
\hline Uganda & 19,1 & 27,4 & 30,9 & 16,7 & 34,4 & 54,5 & 4,8 & 3,6 & 12,3 & 36,7 & 28,4 & 20,9 \\
\hline Zâmbia & 20,8 & 35,7 & 1,3 & 1,1 & 61 & 29,3 & 3,9 & 0,7 & 20,4 & 23,3 & 39,3 & 15,4 \\
\hline Zimbábue & 30,9 & 18,9 & 45,2 & 2,2 & 63,7 & 25,1 & 3,7 & 1,1 & 12,6 & 21,7 & 52,8 & 10,4 \\
\hline TOTAL & 26,8 & 35,2 & 24,9 & 6,6 & 50,6 & 33,3 & 3,5 & 3,1 & 17,5 & 33,3 & 31,3 & 12,6 \\
\hline
\end{tabular}




\section{Anexo I - Grau de semelhança com o Estado}

Estima o grau de semelhança que as instituições pré-coloniais existentes nos territórios correspondentes aos atuais países da África Subsaariana tinham com o Estado moderno. Nas palavras de Englebert (2000b, p. 162), Morrison, Mitchell e Paden (1989) classificaram-nas da seguinte maneira: "para cada país a média do sistema político précolonial, com sociedades acéfalas marcando 1, chefaturas sem importâncias marcando 2, e chefaturas tribais maiores e reinos, 3". Em suma, quanto maior o valor, maior a semelhança com os Estados pós-coloniais.

\begin{tabular}{|l|r|}
\hline País & Grau de semelhança \\
\hline Angola & \\
Benim & 2,67 \\
Botsuana & 2,00 \\
Burquina Faso & 1,25 \\
Burundi & 3,00 \\
Camarões & 1,50 \\
República Centro- & \\
Africana & 1,33 \\
Chade & 2,00 \\
Congo & 1,40 \\
Costa do Marfim & 1,71 \\
Guiné Equatorial & 1,00 \\
Etiópia & 1,86 \\
Gabão & 1,00 \\
Gâmbia & 1,60 \\
Gana & 2,00 \\
Guiné & 2,00 \\
Guiné-Bissau & 1,67 \\
Quênia & 1,83 \\
Lesoto & 3,00 \\
Libéria & 2,40 \\
Madagascar & 2,00 \\
Maláui & 1,80 \\
Mali & 2,00 \\
Mauritânia & 1,67 \\
Moçambique & 1,00 \\
Níger & 2,20 \\
Nigéria & 2,25 \\
Ruanda & 3,00 \\
Senegal & 1,67 \\
Serra Leoa & 2,25
\end{tabular}




\begin{tabular}{|l|r|} 
Somália & 2,00 \\
Sudão & 2,00 \\
Suazilândia & 3,00 \\
Tanzânia & 1,67 \\
Togo & 1,33 \\
Uganda & 1,83 \\
Zaire & 1,71 \\
Zâmbia & 2,00 \\
\hline
\end{tabular}


Anexo II - Modalidades de posse da terra na África Subsaariana Fonte: Herbst (2000)

\begin{tabular}{|c|c|c|c|}
\hline País & $\begin{array}{l}\text { Propriedade } \\
\text { Privada }\end{array}$ & $\begin{array}{l}\text { Arrendamento } \\
\text { Estatal }\end{array}$ & $\begin{array}{c}\text { Reconhece } \\
\text { explicitamente } \\
\text { a posse } \\
\text { costumeira }\end{array}$ \\
\hline Angola & Não & Significante & Não \\
\hline Benim & Existe & Existe & Não \\
\hline Botsuana & Existe & Significante & Sim \\
\hline $\begin{array}{l}\text { Burquina } \\
\text { Faso }\end{array}$ & Não & Existe & Não \\
\hline Burundi & Existe & Significante & Não \\
\hline Camarões & Existe & Significante & Não \\
\hline $\begin{array}{l}\text { República } \\
\text { Centro- } \\
\text { Africana }\end{array}$ & Existe & Existe & Não \\
\hline Chade & Existe & Existe & Não \\
\hline Congo & Não & Existe & Não \\
\hline $\begin{array}{l}\text { Costa do } \\
\text { Marfim }\end{array}$ & Existe & Existe & Não \\
\hline Congo, RD & Não & Existe & Não \\
\hline Etiópia & Não & Significante & Não \\
\hline Gabão & Existe & Não & Não \\
\hline Gâmbia & Existe & Existe & Sim \\
\hline Gana & Existe & Existe & Sim \\
\hline Guiné & Existe & Não & Não \\
\hline $\begin{array}{l}\text { Guiné- } \\
\text { Bissau }\end{array}$ & Existe & Não & Sim \\
\hline Quênia & Significante & Não & Não \\
\hline Lesoto & Não & Significante & Não \\
\hline Libéria & Significante & Desconhecido & Sim \\
\hline Maláui & Significante & Significante & Sim \\
\hline Mali & Existe & Existe & Não \\
\hline Mauritânia & Significante & Significante & Não \\
\hline Moçambique & Não & Significante & Não \\
\hline Namíbia & Significante & Existe & Sim \\
\hline Níger & Existe & Existe & Sim \\
\hline Nigéria & Não & Existe & Não \\
\hline Ruanda & Existe & Existe & Sim \\
\hline Senegal & Não & Existe & Não \\
\hline Serra Leoa & Existe & Existe & Sim \\
\hline Somália & Não & Significante & Não \\
\hline
\end{tabular}




\begin{tabular}{|l|ccl|} 
Sudão & Existe & Existe & Não \\
Suazilândia & Significante & Existe & Sim \\
Tanzânia & Não & Significante & Não \\
Togo & Existe & Existe & Sim \\
Uganda & Existe & Existe & Sim \\
Zâmbia & Não & Significante & Sim \\
Zimbábue & Significante & Existe & Sim \\
\hline
\end{tabular}

\section{Resoluções e Relatórios}

\section{Assembleia Geral dlas Nações Unidas}

A/RES/1514 (XV) - Declaração sobre a Concessão de Independência a Países e Povos Coloniais

A/RES/68/18 - Graduação de Países da Categoria dos Países Menos Desenvolvidos A/RES/70/253 - Graduação de Angola da Categoria dos Países Menos Desenvolvidos

Conselho de Segurança das Nações Unidas

S/RES/696 (1991) - Angola

S/RES/747 (1992) - Angola

S/RES/1173 (1998) - Angola

S/RES/1176 (1998) - Angola

S/RES/866 (1993) - Libéria

S/RES/1020 (1995) - Libéria

\section{Relatório do Secretário-Geral da ONU}

S/2003/875 - Relatório do Secretário-Geral ao Conselho de Segurança sobre a Libéria

Relatório do Conselho de Direitos Humanos da ONU

$\mathrm{A} / \mathrm{HRC} / 29 / 42$ - Report of the commission of inquiry on human rights in Eritrea 